UNIVERSIDADE DE SĀO PAULO

INSTITUTO DE GEOCIENCIAS

\title{
FACIOLOGIA E GÊNESE DOS CARBONATOS DO GRUPO BAMBUÍ NA REGIÃO DE ARCOS, ESTADO DE MINAS GERAIS
}

Jane Nobre Lopes

Orientador: Prof. Dr. Armando Márcio Coimbra

DISSERTAÇÃO DE MESTRADO

COMISSÃO JULGADORA

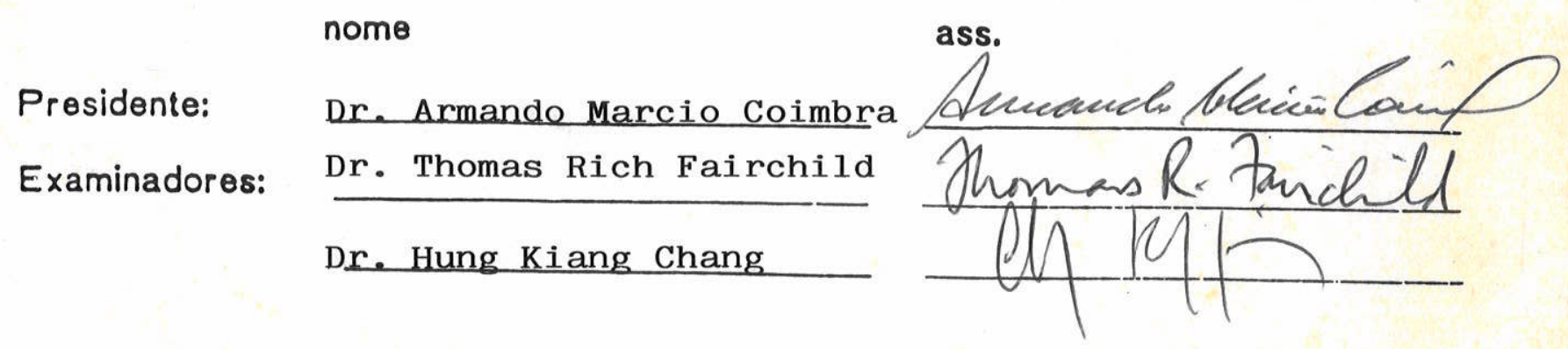




\title{
UNIVERSIDADE DE SĀO PAULO \\ INSTITUTO DE GEOCIENCIAS
}

\section{FACIOLOGIA E GÊNESE DOS CARBONATOS DO GRUPO BAMBUÍ NA REGIÃO DE ARCOS, ESTADO DE MINAS GERAIS}

\author{
Jane Nobre-Lopes \\ Orientador: Prof. Dr. Armando Márcio Coimbra
}

DISSERTAÇÃO DE MESTRADO

Programa de Pós-Graduação em Geologia Sedimentar

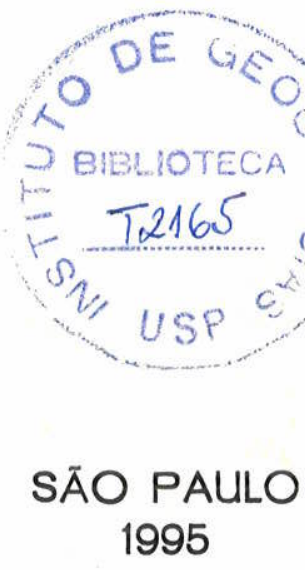




\section{RESUMO}

A pesquisa efetuada na região de Arcos, sudoeste do estado de Minas Gerais, visou definir a faciologia e a gênese dos carbonatos do Grupo Bambuí que ocorrem nessa área. A pesquisa constou basicamente de trabalhos de campo e de descrições petrográficas. Análises palinológicas e de raios $x$ foram realizadas em casos especificos.

Os carbonatos foram caracterizados em fácies sedimentares, as quais foram agrupadas em conjuntos faciológicos, representativos de ambientes de sedimentação bem definidos. A distribuição espacial desses conjuntos e a sucessão em que ocorrem permitiram a identificação de quatro intervalos de sedimentação de caráter regressivo, os quais constituem um megaciclo regressivo.

O Intervalo 1, basal, desenvolveu-se em uma rampa carbonática, talvez do tipo distally steepened. Em ambiente de rampa externa, situado abaixo do nivel de ação de ondas normais, mas afetados por eventos de tempestades, desenvolveu-se em sua parte mais distal, um extenso biostroma composto por calcário microbiarıo críptico, que apresenta intercalações de tempestitos distais (Conjunto de Fácies A1) . O Conjunto de Fácies B1 é composto por tempestitos distais, calcissiltitos, e por calcirruditos relacionados a processos gravitacionais em área de quebra da rampa. Tempestitos proximais, com variações locais de fácies, compõem o Conjunto de Fácies C1.

O Conjunto de Fácies D1 é composto por corpos arenosos, os quais constituiam baixios situados a diferentes profundidades, eram afetados pela ação de ondas normais e são o elo de ligação entre as fácies distais de rampa externa e as fácies perilitorâneas, de águas rasas. Onde os corpos arenosos constituiam barreira efetiva, talvez do tipo ilhasbarreiras, terminaram por isolar uma laguna, com planície de maré, onde se desenvolveram dolomitos estromatolíticos (Conjunto de Fácies E1). Onde os corpos arenosos estavam submersos, o ambiente apresentava maior energia, o que propiciou 0 
desenvolvimento de dolarenitos ooidais que ocorrem associados a estromatólitos de grande porte (Conjunto de Fácies F1). Um evento de exposição subaérea afetou as fácies de topo do Intervalo 1, e provocou dissolução, com abertura de cavidades, formação de brechas de colapso e o desenvolvimento de um possivel nivel de calcrete laminado.

O Intervalo 2 é eminentemente estromatolítico e tem início com rápida subida do nivel do mar, que recobriu a plataforma carbonática exposta com águas rasas, em clima quente e semi-árido. Nesse novo espaço instalaram-se planícies de maré cíclicas, com predomínio de estromatólitos estratiformes, que eventualmente apresentam cristais aciculares de anidrita e de gretas de contração, indicando que o ambiente era sujeito à concentração de sais, com ressecações periódicas.

Os Intervalos 3 e 4 desenvolveram-se em plataforma carbonática do tipo rimmed shelf e constituem ciclos Oolite-Grainstone, caracteristicos de plataformas carbonáticas amplas e de águas rasas. Biohermas estromatolíticos ocorrem em ambiente de plataforma externa (Conjuntos de Fácies G3 e G4) e de middle shelf (Conjuntos de Fácies H3 e H4), onde corpos oolíticos constituem baixios arenosos. No Intervalo 3, as fácies de middle shelf apresentam gradação para planície de maré lamosa, restrita, de baixa energia (Conjunto de Fácies F3), em direção à linha de costa, a qual guarda semelhanças com ciclos do tipo Lime mud-Sabkha. No Intervalo 4, a presença de corpos oolíticos é mais expressiva e os biohermas estromatolíticos são mais possantes, o que sugere para esse intervalo uma transgressão de maior amplitude.

A evolução de uma plataforma carbonática, inicialmente do tipo rampa, para plataforma com quebra de relevo em áreas proximais (rimmed shelf), constitui a regra geral das plataformas proterozóicas, à semelhança com o que ocorre no Fanerozóico.

Os principais aspectos diagenéticos observados referem-se à compactação, importante nos carbonatos argilosos; à dissolução, que afeta as litologias de topo do Intervalo 1 e, mais especialmente, à dolomitização, que pode estar relacionada ao 
ambiente deposicional e ser precoce, ou estar relacionada à flutuação da interfácies água doce - água salobra, quando a dolomitização é tardia. 


\section{ABSTRACT}

The area object of this research is located in the Arcos region, in the soutwest part of the state of Minas Gerais. The purpose of the research is to understand the facies distribution and the origin of the carbonate sequences of the Bambui Group that occur in that area. Detailed description of outcrops and petrographic analysis were the principal activities of the research. Palynologic and X-ray analyses were made in some specific cases.

The carbonate rocks were classified in sedimentary facies and assembled in facies groups representing well defined environments of sedimentation. The spatial distribution of these groups of facies and the sequence in which they occur permitted to identify four Intervals of regressive sedimentation, constituting a regressive, progradational megacycle.

The Interval 1 is basal and developed on a carbonatic ramp, possibly of distally steepened type. In deep ramp, below the fairweather wave base, but affected by storm events, developed a large biostrome composed of cryptical microbial limestone, which presents some distal storm layers (Facies Group A1). The Facies Group B1 is composed by distal storm deposits, specially calcisiltites, and calcirudites related to gravitational processes possible in areas of slope of the ramp. Proximal storm layers, with local facies variations, constitute the Facies Group C1.

The Facies Group D1 is composed by sand bodies that constituted shoals at various depths, affected by the action of normal waves. The sand bodies are the linking between the distal facies of the outer ramp and the back ramp facies of shoreline. In some places the sand bodies constituted effective barriers, and possibly permited the development of a beach barrier island-lagoonal sucession, with the formation of a dolomitized stromatolitic facies in the lagoon (Facies Group E1). Where the sand bodies 
were subaqueous, the environment was of higher energy and propitiated the development of ooidal dolostones associated to stromatolites (Facies Group F1). An event of subaerial exposure affected the top facies of the Interval 1 and was responsible for the partial dissolution of the carbonate, with the opening of cavities, development of collapse breccias and possible of a layer of laminated calcrete.

The Interval 2 is predominantly stromatolitic and begins with a rapid sea-level rise that covered the exposed carbonatic platform with shallow water, in a hot and semiarid climate. Cyclic tidal flats were installed, composed predominantly by stratiform stromatolites, which occasionally present acicular crystals of anhidrite and polygonal cracks, that indicate that the environment was subjected to salt concentration and periodic dissecation.

The Intervals 3 and 4 were developed in a carbonate platform of rimmed shelf type and constituted Oolite-Grainstone Cycles, characteristic of wide shelves with shallow waters. Stromatolitic bioherms occur in external platform environment (Facies Groups G3 and G4) and in the middle shelf (Facies Groups H3 and H4), where oolite bodies constitute shoals. In the Interval 3, the middle shelf facies present a transition to a restricted tidal flat of low energy (Facies Group F3) whose characteristics are somewhat similar to Lime mudSabkha Cycles. In the Interval 4, the presence of oolitie bodies is important and the stromatolitic bioherms are larger than in the Interval 3, suggesting a great sea level fluctuation for this Interval.

The evolution of a carbonate platform, initially from the ramp type to a rimmed shelf constitute a common situation in Proterozoic carbonatic platforms, as well as in Fanerozoic ones.

Compaction, dissolution and dolomitization are the principal diagenetic aspects described in the area. Compaction is siginificant in the argillaceous limestones, and dissolution affects the top litologies of Interval 1. Dolomitization is the principal diagenetic 
aspect, and may be either related to the depositional environment (an early dolomitization) or related to fluctuation of the meteoric-marine mixing zone (a late dolomitization). 


\section{AGRADECIMENTOS}

A realização desse trabalho foi possivel graças à colaboração e estímulo de várias pessoas e instituições. Entre as instituiçöes cumpre ressaltar a Companhia de Pesquisa de Recursos Minerais (CPRM), o Instituto de Geociências da Universidade de São Paulo, a Coordenação de Aperfeiçoamento de Pessoal de Ensino Superior (CAPES), o Conselho Nacional de Desenvolvimento Científico e Tecnológico(CNPq) Convênio RHAE, o Centre Géologique et Géophysique - CGG - CNRS, da Universidade de Montpellier, a Companhia Siderúrgica Nacional - CSN e a Companhia de Mineração de Minas Gerais -COMIG.

Entre as pessoas que me auxiliaram, agradeço especialmente ao Prof. Dr. Armando Márcio Coimbra, meu orientador, pela preciosa colaboração e paciência no decorrer dos trabalhos, e especialmente por todos os contratempos, que não foram poucos.

Agradeço imensamente à Doutora Janine Bertrand-Sarfati e Professor Paulo Tibana, pelo enorme apoio, boa vontade e disponibilidade, o que me ajudou imensamente. À Doutora Janine Sarfati agradeço ainda a generosa acolhida quando da minha estada em Montpellier e o apoio fundamental para o estudo da microestrutura de estromatólitos. Ao Professor Tibana, agradeço ainda a permissão e orientação, quando da obtenção de microfotografias na UNICAMP.

Ao Prof. Dr. Thomas R. Fairchild, agradeço a paciência com as discussões no início do curso de pós-graduação e a cessão de material fotográfico para a dissertação.

No âmbito da CPRM, agradeço ao geólogo Valter José Marques, à época, Superintendente de Recursos Minerais, SUREMI, por ter permitido que eu desenvolvesse o projeto de pós-graduação, ao Superintendente da SUREG/Belo Horizonte, Osvaldo Castanheira, pela boa vontade e cessão de veículos e motorista, 0 que foi fundamental no desenrolar dos trabalhos, bem como à secretária Valéria, por todas as gentilezas; mais especialmente, agradeço ao sr. José da Paz, excelente motorista, que me acompanhou na maior parte das etapas de campo, e cuja disposição e gentileza, tornaram o trabalho de campo extremamente eficiente e gratificante. No DEGEO, agradeço a Fátima da Conceição de Oliveira Ramos e Martim Elias Dias, pelo apoio prestado. Agradeço também ao desenhista cartógrafo Luiz Guilherme de A. 
Frazão, responsável pelo setor de desenho do Centro de Cartografia, CECAR, e à sua equipe, pelo apoio, presteza e boa vontade, sem a qual não teria sido possivel obter o material de desenho tão prontamente.

Na região de Arcos, no âmbito da CSN, agradeço ao Superintendente da Mina da Bocaina, Eng. Luiz Antônio Cipriani, pela facilidade de acesso, apoio logístico e gentileza, em todas as inúmeras vezes em que lá estive; agradeço ainda ao Eng. geólogo Antônio José Salvador, pelo apoio e camaradagem no decorrer dos trabalhos, bem como a todos que, como o Eng. Vanin, sempre me receberam com gentileza, cordialidade $e$ interesse pelo trabalho desenvolvido. $\mathrm{Na}$ COMIG, agradeço a autorização para trabalhar em suas áreas de lavra, bem como a gentileza de todos os que me atenderam, em especial o sr. Li Queiroz e a secretária Carminha.

No Laboratório de Sedimentologia do Instituto de Geociências da Usp, sempre contei com a ajuda e gentileza da Elaine, a qual me ajudou inúmeras vezes a resolver problemas que a distância criava. Também agradeço ao Sérgio Luis Fabris de Matos pelas inúmeras vezes que resolveu problemas burocráticos em meu lugar, o que muito me ajudou. Finalmente agradeço à amiga Vera Nouer Hempel e a todos os seus pela calorosa acolhida nas inúmeras vezes que lá estive hospedada, o que foi fundamental para o bom desenrolar dos trabalhos.

A todos, muito obrigada! 
INDICE

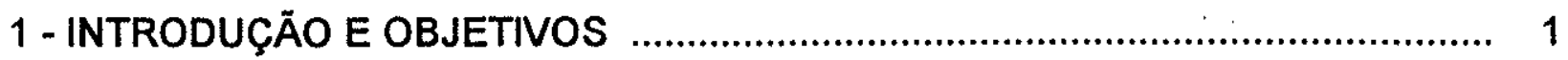

2 - GRUPO BAMBUÍ ..................................................................................... 3

2.1 - HISTÓRICO DO CONHECIMENTO ……....................................................... 3

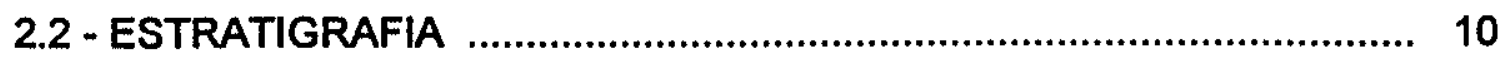

2.3 - EVOLUÇÃO TECTONO-SEDIMENTAR .......................................... 11

2.4 - LOCALIZAÇÃO DA ÁREA PESQUISADA E GEOLOGIA LOCAL ....... 12

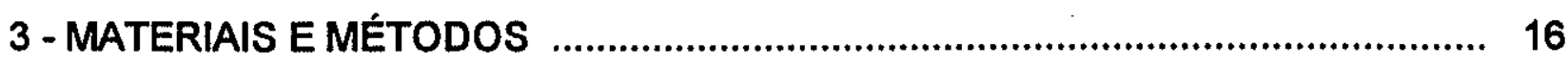

4 - DESCRIÇÃO DAS ROCHAS CARBONÁTICAS …............................................ 21

4.1 - CARBONATOS DETRITICOS …..................................................... 21

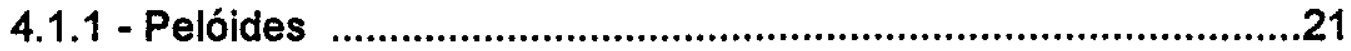

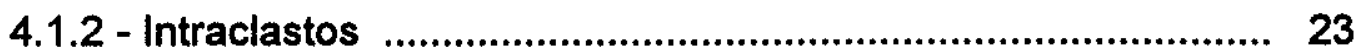

4.1 .3 - Oólitos ............................................................................... 23

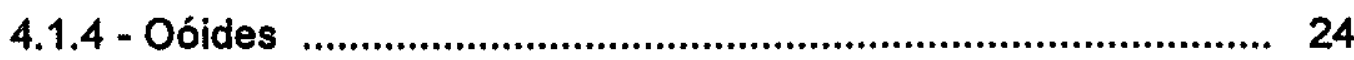

4.1.5 - Oncólitos ............................................................................. 24

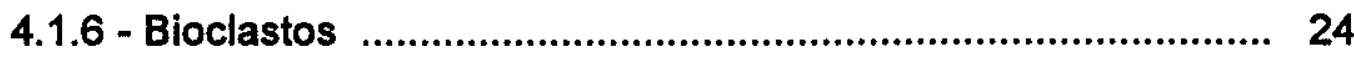

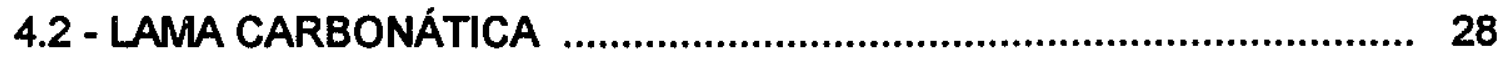

4.3 - BIOCONSTRUÇÕES ................................................................. 28

4.4 - CLASSIFICAÇŐES ADOTADAS PARA AS ROCHAS

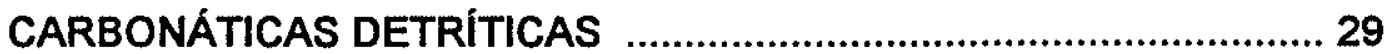

4.4.1 - Classificação de Folk $(1959,1962)$......................................... 29

4.4.2 - Classificação de Dunham (1962) .......................................... 30

4.4.3 - Classificação de Embry \& Klovan (1971) ............................... 30

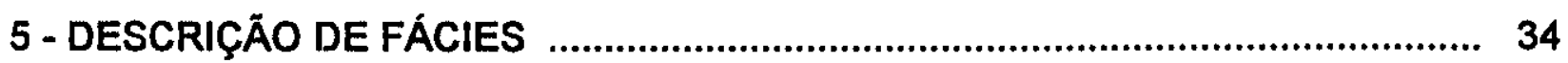

5.1 - FÁCIES Cm - Calcário microbiano críptico ......................................... 34

5.2 - FÁCIES Cs - Calcissiltitos ............................................................. 48

5.3 - FÁCIES Cr - Calcirruditos .......................................................... 52

5.4 - FÁCIES Crg - Calcirruditos/calcarenitos com gradaçäo normal .......... 56

5.5 - FÁCIES Crf - Calcirruditos sustentados pela matriz ............................. 60

5.6 - FÁCIES CaCrD - Calcarenitos/ calcirruditos dolomíticos com granodecrescência ascendente ........................................................... 62 
5.7 - FÁCIES CaDz - Calcarenito dolomítico com estratificação cruzada ... 64

5.8 - FÁCIES CaDa - Calcarenito dolomítico com estratificação cruzada

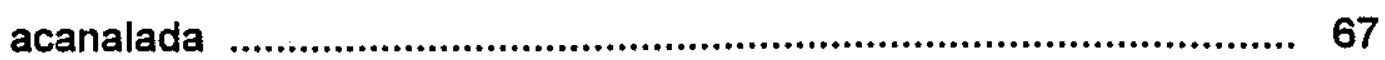

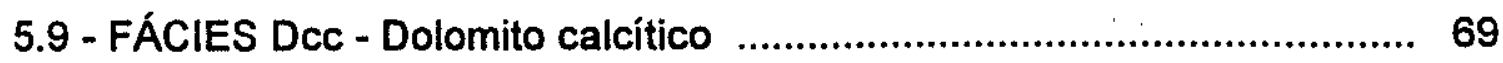

5.10 - FÁCIES DEd - Dolomito estromatolítico com elementos dômicos de

pequeno porte .............................................................................. 71

5.11 - FÁCIES DEdc - Dolomito estromatolitico com formas dômicas e colunares associado a dolarenito ooidal ..................................... 72

5.12 - FÁCIES DECP - Dolomito estromatolítico com formas colunares a pseudocolunares ......................................................................... 72

5.13 - FÁCIES DEb - Dolomito estromatolítico estratiforme com brecha de dissolução associada ...................................................................... 77

5.14 - FÁCIES DI - Dolomito com laminação irregular .................................. 77

5.15 - FÁCIES DEes - Dolomitos estromatolíticos estratiformes e intercalações de dolomitos não estromatolíticos ............................. 80

5.15 .1 - Dolomitos não estromatolíticos ........................................ 80

5.15.2 - Dolomitos estromatolíticos estratiformes ........................... 83

5.15 .3 - Dolomito laminado .............................................................. 94

5.16 - FÁCIES CE - Calcários estromatolíticos .......................................... 94

5.17 - FÁCIES Cait - Calcarenitos intraclásticos ......................................... 103

5.18 - FÁCIES Caoo - Calcarenitos oolíticos ………......................................106

5.19 - FÁCIES Can - Calcarenitos neomorfizados ..................................... 112

5.20 - FÁCIES CaCl - Calcarenito com intercalações de calcilutitos ............ 116

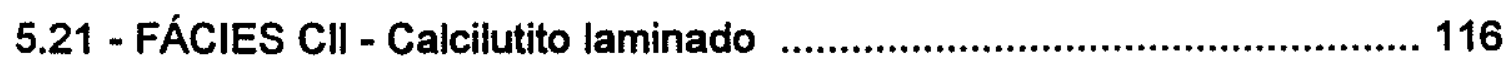

5.22 - FÁCIES CsI - Calcissiltitos laminados …........................................... 116

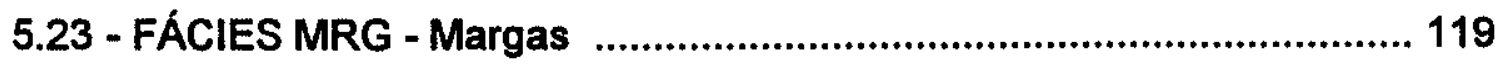

6 - DIAGÊNESE

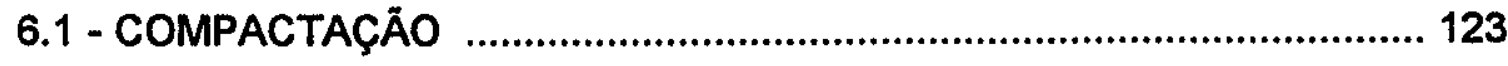

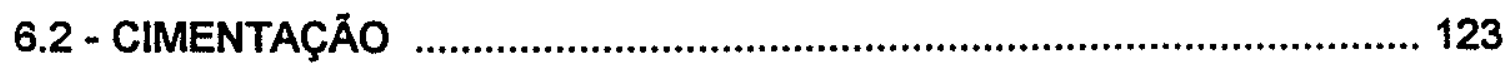

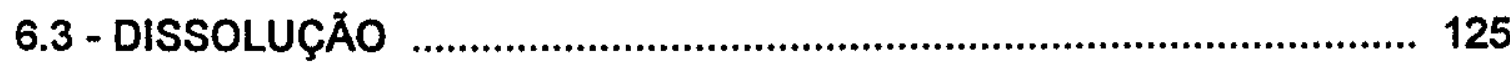

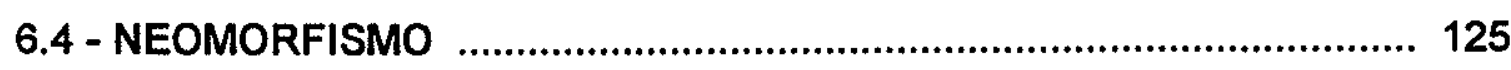

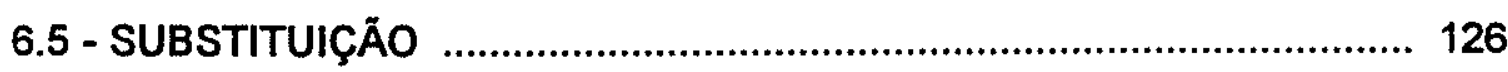

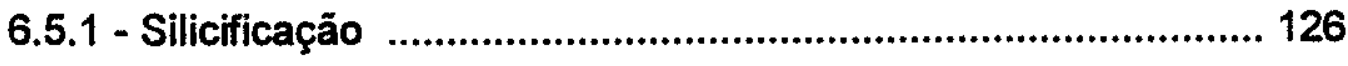




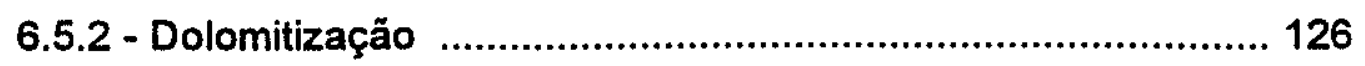

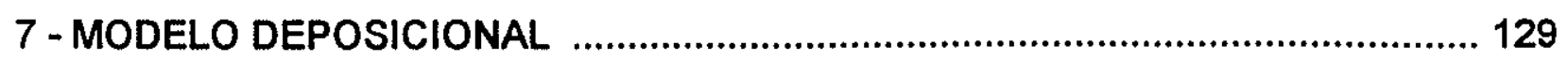

7.1 - INTERVALO 1

7.2 - INTERVALO 2

7.3 - INTERVALO 3

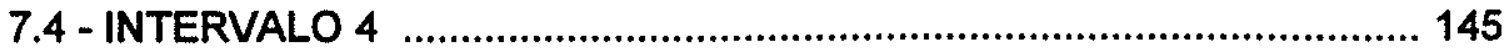

7.5 - DISCUSSÃO DOS MODELOS DE PLATAFORMA

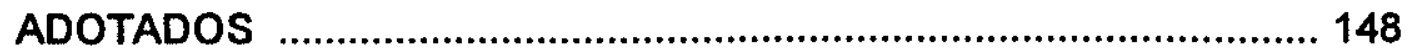

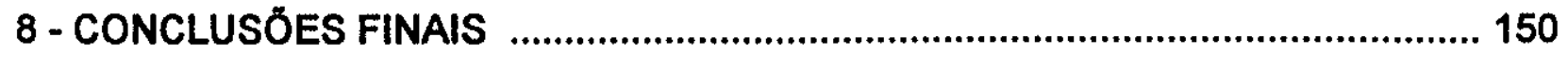

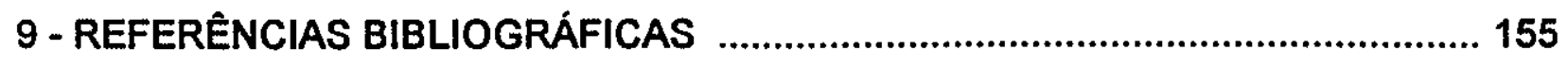




\section{ÍNDICE DAS FIGURAS}

Figura 1 - O Cráton do São Francisco e suas faixas de dobramentos marginais

Figura 2 - Evolução das subdivisōes estratigráficas propostas para o Grupo Bambuí .5

Figura 3 - Localização da área Pesquisada 13

Figura 4 - Esboço geológico da região do alto Rio São Francisco, dividido em domínio estruturais .15

Figura 5 - Classificação de Folk (1962) para rochas carbonáticas e texturas de carbonatos.

Figura 6 - Classificações de Dunham (1962) e Embry \& Klovan (1971) para rochas carbonáticas

Figura 7 - Distribuição das fácies e estruturas sedimentares do Perfil 1, na Mina da Bocaina .39

Figura 8 - Distribuição das fácies e estruturas sedimentares no perfil composto pelos perfis 2 e 4 40

Figura 9 - Distribuição das fácies e estruturas sedimentares do Perfil 3, na mina abandonada da COMIG

Figura 10 - Detalhe das fácies $\mathrm{Cr}$, Cs e Crg, no Perfil 2, na entrada da COMIG

Figura 11 - Correlaçōes das fácies e Conjuntos Faciológicos no Intervalo 1

Figura 12 - Blocos-diagramas e Perfil do Intervalo 1 132

Figura 13 - Intervalo 3 - Perfil das fácies de uma plataforma carbonática do tipo rimmed

Figura 14 - Intervalo 4 - Perfil das fácies de uma plataforma carbonática do tipo rimmed 


\section{ÍNDICE DAS TABELAS}

Tabela 1 - Descrição das fácies de carbonatos detriticos .35

Tabela 2 - Descrição das fácies de bioconstruções ...................................37

Tabela 3 - Conjuntos Faciológicos 129 


\section{1 - INTRODUÇÃO E OBJETIVOS}

Este texto apresenta uma sintese do histórico do conhecimento do Grupo Bambuí, os principais trabalhos referentes à área estudada, materiais e métodos utilizados na pesquisa e os resultados obtidos com o levantamento da seção carbonática exposta na região de Arcos, no centro-oeste do estado de Minas Gerais.

O Grupo Bambuí insere-se na Bacia do São Francisco, ocupando uma área superior a $200.000 \mathrm{Km}^{2}$, e constitui uma cobertura de plataforma sobre o Cráton do São Francisco (Figura 1), um extenso núcleo estabilizado ao final do Ciclo Transamazônico $(1,8-2,0 \mathrm{Ga})$, e margeado por faixas de dobramento de idade brasiliana $(700-500 \mathrm{Ma})$.

Os objetivos desta pesquisa, desenvolvida a partir do estudo detalhado dos carbonatos do Grupo Bambuí aflorantes na porção sudeste da Bacia do São Francisco, são:

1-o estabelecimento da seção geológica da área;

2-o reconhecimento de conjuntos e sucessões faciológicas que permitam caracterizar ciclos de sedimentação;

3-a identificação dos estromatólitos quanto à sua morfologia e significado ambiental;

4-a reconstituição paleogeográfica da área;

5-a identificação dos principais aspectos diagenéticos dos carbonatos. 


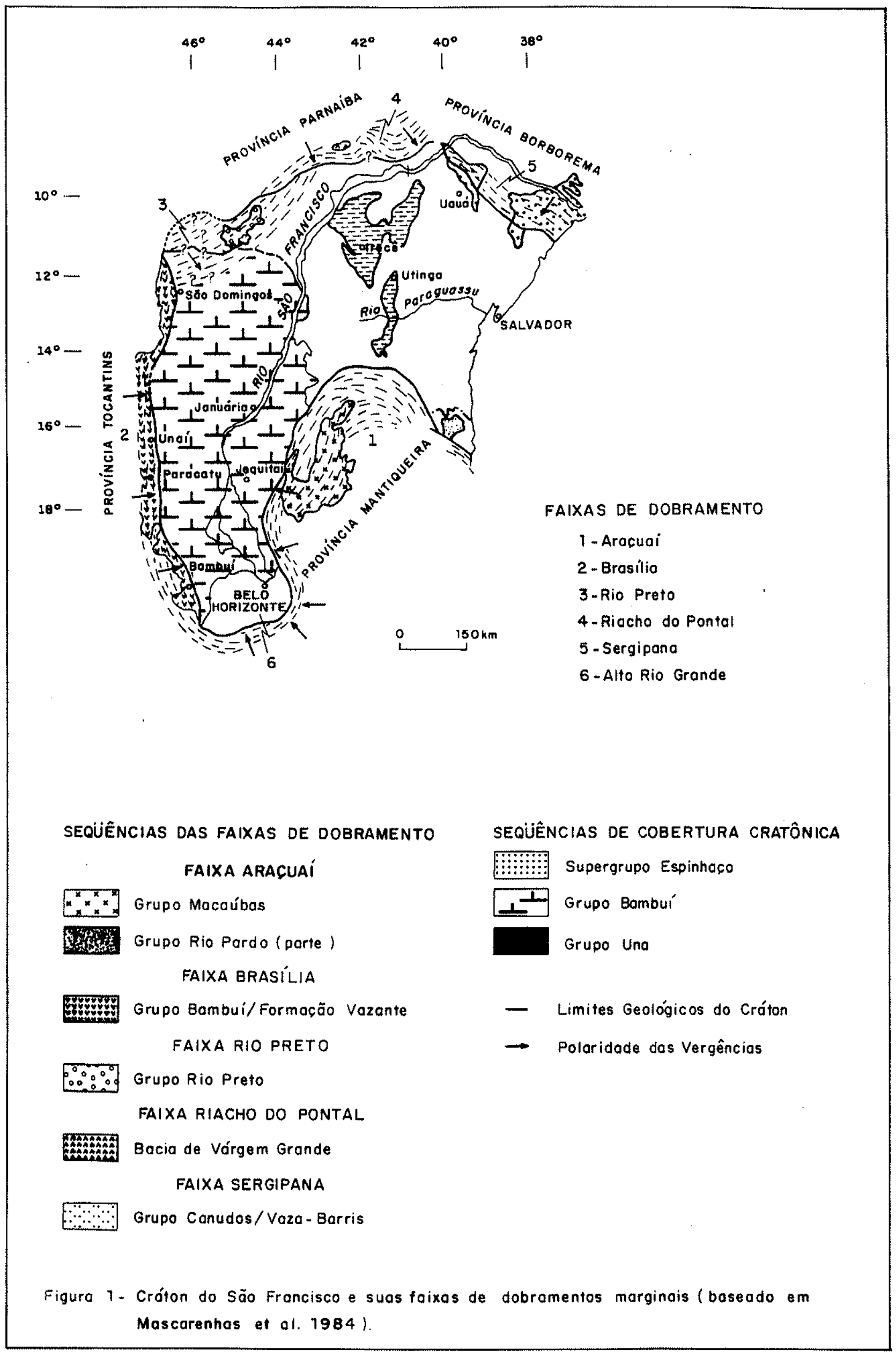




\section{1 - HISTÓRICO DO CONHECIMENTO}

As primeiras referências feitas à geologia da área ocupada pelo Grupo Bambuí remontam ao século dezenove. Constituem, no geral, roteiros de viagens, onde são descritos os aspectos geográficos, geológicos, botânicos e climáticos da regiäo percorrida.

Um dos primeiros trabalhos de cunho geológico foi o de Eschwege, em 1832 (apud Costa et al. 1970), que descreveu na cachoeira de Pirapora, uma formação arenosa, essencialmente horizontal, superposta a xistos argilosos mais antigos, a qual denominou de "Arenito Pirapora". A seqüência de calcários, xistos e arenitos que ocorre na região foi por ele considerada como pertencente aos "Terrenos de Transição" (Uebergansgebirge), sendo essa a primeira designação estratigráfica aplicada ao Grupo Bambuí.

Derby (1880), em seu "Reconhecimento Geológico do Valle de São Francisco", discorre sobre a geologia e a topografia da região percorrida, descreve o grés exposto na cachoeira de Pirapora, a serra do Caboclo e as extensas regiões constituídas por calcários. Ainda em 1880, Derby publicou "Contribuição à Geologia do Rio São Francisco", onde descreve seqüências pelíticas e carbonáticas, fazendo referência ao Calcário do São Francisco, sem no entanto propor formalmente o termo.

Em 1917, Rimann cunhou o termo "Série Bambui" para descrever os "xistos argilosos e argilas xistosas" sobrepostos aos "xistos cristalinos da Série Minas", que ocorrem na região da Serra da Mata da Corda, a oeste do rio São Francisco.

Rimann considerou a "Série Bambuí" de idade siluriana, embora não com certeza, baseado nos fósseis identificados por Derby (1880), nas "rochas calcárias da mesma formação em Bom Jesus da Lapa".

Freiberg, em 1932, num dos mais importantes trabalhos da época sobre a geologia e a estratigrafia da regiâo central de Minas Gerais e em especial sobre a "Série Bambui", distingue, seguindo idéia de Rimann, duas seqüências, que denominou Camadas Indaiá e Camadas Gerais.

Nas Camadas Indaiá, dobradas, predominam rochas argilo-arenosas, os "xistos da Série Bambuí", com lentes de calcário, às vezes de grandes proporções.

As Camadas Gerais são horizontalizadas, com predomínio de "xistos argilosos, xistos quartzíticos, quartzitos em placas", além de "quartzitos maciços ou em bancos espessos" e calcários. 
Freiberg discute as várias idades aventadas para a "Série Bambui" e, após criterioso juizo, coloca as Camadas Gerais no Devoniano.

Miranda (1951 e 1952) quando em viagens ao municipio de Bambuí, descreve o Conglomerado Samburá, considerado por alguns autores como a unidade basal do Grupo Bambuí.

Nos anos sessenta, começaramm a surgir importantes trabalhos de cunho estratigráfico, como o de Costa \& Branco (Figura 2), que em 1961, fizeram a primeira tentativa após Freiberg (1932), de estabelecer uma divisão litoestratigráfica de âmbito regional, quando da elaboração da seção estratigráfica entre Belo Horizonte e Brasília. Dividiram a "Série Bambuí" nas formaçōes Carrancas, Sete Lagoas e Rio Paraopeba, esta última composta pelos membros Serra de Santa Helena (base), Lagoa do Jacaré, Três Marias, e no topo, Serra da Saudade. No trabalho original, a Formação Paraopeba está referida como Formação Rio Piracicaba, mas Baptista et al. (1984), constataram tratar-se de um erro de impressão.

Os autores traçaram também o primeiro esboço do ambiente deposicional dos diferentes membros da série, considerando que a sedimentação inicialmente deu-se em águas profundas e tranqüilas, passando a águas rasas, com maior turbulência no topo da seqüência, "à medida que a bacia foi se enchendo".

Consideraram os limites da série no vale do rio São Francisco como sendo de origem tectônica, ao longo de falhas de empurrão, onde as rochas apresentam-se fortemente deformadas.

Quanto à idade, acreditaram que a série não deve ser mais nova que o Cambriano.

Barbosa, em 1965, sugere nova subdivisão para a série e coloca o Conglomerado Samburá (Miranda op. cit.) como unidade basal, elevando-o à condição de formação. Considera-o como indicativo de uma transgressão marinha.

Oliveira (1967), trabalhando na parte sul da bacia do São Francisco, modificou a divisão da "Série Bambuí" proposta por Costa \& Branco (1961), subdividindo-a nas formações Vila Chapada (composta por dois membros), Sete Lagoas, Serra de Santa Helena e Lagoa do Jacaré, as quais compōem o nivel estratigráfico inferior do Grupo São Francisco; a Formação Três Marias constituiria o nivel estratigráfico superior.

Deve-se a Almeida (1967), a classificação da "Série Bambui" na categoria de grupo.

Braun, em 1968, resumiu a estratigrafia do Grupo Bambuí a três formaçōes. A formação basal foi denominada Paranoá. A intermediária é a Formação Paraopeba, composta pelas fácies Samburá (basal), Sete Lagoas, Serra de Santa Helena e Lagoa do Jacaré; a Formação Três Marias é a unidade de topo do Grupo Bambuí. 


\begin{tabular}{|c|c|c|c|c|c|c|c|}
\hline \multicolumn{2}{|c|}{ COSTA \& BRANCO (1961) } & \multirow{2}{*}{$\begin{array}{c}\text { BARBOSA (1965) } \\
\text { Formações }\end{array}$} & \multirow{2}{*}{$\frac{\text { OLNEIRA (1967) }}{\text { Formaçöes }}$} & \multirow{2}{*}{$\frac{\text { BRAUN (1968) }}{\text { Formaçöes }}$} & \multirow{2}{*}{$\begin{array}{c}\text { DARDENNE (1978) } \\
\text { Formaçöes }\end{array}$} & \multicolumn{2}{|c|}{ RADAMBRASIL (1982) } \\
\hline Membros & Formaçōes & & & & & & Formaçöes \\
\hline $\begin{array}{c}\text { Serra } \\
\text { da } \\
\text { Saudade }\end{array}$ & \multirow{4}{*}{ Paraopeba } & \multirow{2}{*}{$\begin{array}{l}\text { Três } \\
\text { Marias }\end{array}$} & \multirow{2}{*}{$\begin{array}{l}\text { Três } \\
\text { Marias }\end{array}$} & \multirow{2}{*}{$\begin{array}{l}\text { Três } \\
\text { Marias }\end{array}$} & $\begin{array}{c}\text { Três } \\
\text { Marias }\end{array}$ & & $\begin{array}{c}\text { Três } \\
\text { Marias }\end{array}$ \\
\hline $\begin{array}{l}\text { Três } \\
\text { Marias }\end{array}$ & & & & & $\begin{array}{l}\text { Serra da } \\
\text { Saudade }\end{array}$ & \multirow{3}{*}{$\begin{array}{l}S \\
u \\
b \\
g \\
r \\
u \\
p \\
o\end{array}$} & $\begin{array}{l}\text { Serra da } \\
\text { Saudade }\end{array}$ \\
\hline $\begin{array}{l}\text { Lagoa } \\
\text { do } \\
\text { Jacaré }\end{array}$ & & $\begin{array}{l}\text { Lagoa } \\
\text { do } \\
\text { Jacaré }\end{array}$ & $\begin{array}{l}\text { Lagoa } \\
\text { do } \\
\text { Jacaré }\end{array}$ & \multirow{3}{*}{ Paraopeba } & $\begin{array}{l}\text { Lagoa } \\
\text { do } \\
\text { Jacaré }\end{array}$ & & $\begin{array}{l}\text { Lagoa } \\
\text { do } \\
\text { Jacaré }\end{array}$ \\
\hline \multirow[t]{4}{*}{$\begin{array}{c}\text { Serra } \\
\text { de } \\
\text { Santa } \\
\text { Helena }\end{array}$} & & $\begin{array}{c}\text { Serra } \\
\text { de } \\
\text { Santa } \\
\text { Helena }\end{array}$ & $\begin{array}{c}\text { Serra } \\
\text { de } \\
\text { Santa } \\
\text { Helena }\end{array}$ & & $\begin{array}{c}\text { Serra } \\
\text { de } \\
\text { Santa } \\
\text { Helena }\end{array}$ & & $\begin{array}{c}\text { Serra } \\
\text { de } \\
\text { Santa } \\
\text { Helena }\end{array}$ \\
\hline & $\begin{array}{l}\text { Sete } \\
\text { Lagoas }\end{array}$ & $\begin{array}{l}\text { Sete } \\
\text { Lagoas }\end{array}$ & $\begin{array}{l}\text { Sete } \\
\text { Lagoas }\end{array}$ & & $\begin{array}{l}\text { Sete } \\
\text { Lagoas }\end{array}$ & \multirow{3}{*}{$\begin{array}{l}\mathrm{P} \\
\mathbf{a} \\
\mathrm{r} \\
\mathbf{a} \\
\mathbf{o} \\
\mathbf{p} \\
\mathrm{e} \\
\mathbf{b} \\
\mathbf{a}\end{array}$} & $\begin{array}{c}\text { Sete } \\
\text { Lagoas }\end{array}$ \\
\hline & \multirow[t]{2}{*}{ Carrancas } & Paranoá & \multirow[t]{2}{*}{ Vila Chapada } & \multirow{2}{*}{$\begin{array}{l}\text { Paranoá } \\
\text { Fácies } \\
\text { Carrancas }\end{array}$} & \multirow[t]{2}{*}{ Jequital } & & \multirow{2}{*}{$\begin{array}{l}\text { Samburá / } \\
\text { Carrancas }\end{array}$} \\
\hline & & Samburá & & & & & \\
\hline
\end{tabular}

Figura 2 - Evolução das subdivisōes estratigráficas propostas para o Grupo Bambul 
Barbosa et al. (1970) consideraram a idade do Grupo Bambui situada entre o Precambriano Superior e o Cambriano Inferior.

Dardenne, em 1978, procurando estabelecer correlações litoestratigráficas na bacia, buscou a uniformização da nomenciatura estratigráfica, a partir da divisão estratigráfica proposta por Costa \& Branco (1961). Assim, dividiu o Grupo Bambuí nas formaçōes Jequitai (basal), Sete Lagoas, Serra de Santa Helena, Lagoa do Jacaré, Serra da Saudade e Três Marias .

Marini et al. em 1978 incluem o Conglomerado Samburá na Formação Jequitaí.

Couto \& Bez, em 1981, discutem a problemática da Glaciação Jequitaí e sua inserçäo como base do Grupo Bambuí. Consideraram que a unidade portadora de tilitos deveria ser considerada como uma unidade em separado, discordante em relação ao Grupo Bambui. $\mathrm{Na}$ base do grupo ficariam apenas os conglomerados descontínuos e de pequena espessura, como o Conglomerado Carrancas (Costa \& Branco 1961). Os Tilitos Jequitaí passariam a pertencer ao Grupo Macaúbas. Confirmam assim as observações de Oliveira (1967), que baseado em critérios estratigráficos e paleoclimáticos, considerou a Formação Jequitai como uma unidade discordante em relação ao Grupo Bambuí.

Karfunkel \& Hoppe (1988) incluem o Conglomerado Samburá na Formaçäo lbiá (Barbosa et al. 1970) e a correlacionam aos grupos Macaúbas e São João Del Rey e à Formação Bebedouro, considerados como tendo sido depositados em ambiente glacial ou sob influência glacial.

Madalosso \& Veronese (1978), trabalhando na região sudoeste da Bacia do São Francisco, foram os primeiros a abordar o Grupo Bambui em detaihe, discutindo os seus aspectos litológicos e ambientes de sedimentação. Enquadraram as litologias dessa área na Formação Paraopeba (Braun 1968) e as dividiram em duas fácies, pelítica e carbonática.

A Fácies Carbonática predomina na região de Arcos e Pains, ocorrendo também nas proximidades de Lagoa da Prata e Moema. É constituída por calcários, dolomitos e margas. Essa fácies foi subdividida em 7 unidades litoestratigráficas, sendo constituída, da base para o topo, por margas, calcário plaqueado, caracterizado por um calcário preto, carbonoso, fétido, no geral micrítico. Segue-se um pacote de calcarenitos e brechas que apresentam laminaçöes cruzadas planares de porte médio. Acima ocorre um dolomito sacaróide calcifero, de cor cinza, poroso e maciço, com porçōes micríticas, laminadas, onde se observam vestígios de oólitos, pelóides e intraclastos. 
A seguir vem o dolomito laminado, calcifero, onde se observam estromatólitos colunares do tipo SH e LLH-C (Logan et al. 1964), bem como laminações algáceas, que ocasionalmente podem conter intercalações centimétricas de dolarenitos.

O calcário com estromatólitos é constituido por calcário preto, com estromatólitos do tipo SH (Logan et al. 1964); contém nódulos e lentes de sílex preto, bem como pequenas lentes de material silto-argiloso. O calcário de topo é de cor preta, micrítico e pode conter delgadas intercalaçöes de material argilo-carbonoso ou niveis oolíticos. Apresenta lentes de silex preto.

Segundo Madalosso \& Veronese (1978), as rochas do Grupo Bambuí resultam de 3 ciclos regressivos após transgressões marinhas e são separados por hiato deposicional ou evento de exposição subaérea. Consideram que a deposição inicial dos carbonatos se deu sobre um alto, com a sedimentação dos sedimentos pelíticos em áreas de profundidade média e águas calmas.

Magalhães (1989) trabalhando na região centro-oeste do estado de Minas Gerais, dá ênfase ao aspecto estrutural dos sedimentos do Grupo Bambui, mas aborda também o aspecto estratigráfico e os ambientes de sedimentação. Divide o Grupo Bambuí em quatro fácies, denominadas, da base para o topo: Conglomerática, Pelítica, Carbonática e Psamo-Pelítica.

A Fácies Conglomerática faz contato basal com as rochas do Grupo Canastra ou do embasamento gnaissico-migmatítico.

A Fácies Pelítica é composta predominantemente por argilitos, com intercalaçōes subordinadas de siltitos.

A Fácies Carbonática foi dividida em 6 unidades distintas:

Calcilutitos e margas constituem a unidade basal, sendo seguida por calcarenitos de coloração cinza escuro, onde são identificados niveis de brechas e niveis finamente estratificados, de aspecto plaqueado, com lâmina de argila no plano de acamamento. As brechas contém intraclastos lamelares e ocorrem tanto nos calcarenitos como nos niveis plaqueados. A seguir tem-se o calcarenito dolomítico, que corresponde ao dolomito sacaróide de Madalosso \& Veronese (1978).

Os dolarenitos são de cor cinza claro, com laminaçōes algáceas e estromatólitos do tipo SH e LLH-C (Logan et al. 1964). O pacote de calcarenito estromatolítico/dolarenito calcítico/calcirrudito dolomítico é de cor preta, apresenta lentes de silex e tem, no topo, niveis com gretas de contração. Os estromatólitos são predominantemente do tipo SH.

O calcário de topo é preto e apresenta intercalações centimétricas a milimétricas de argila. 
A Fácies Psamo-Pelitica contém argilitos na base, que passam a argilitos com intercalações de siltitos e, mais raramente, a arenitos no topo.

Quanto ao ambiente de sedimentação, a Fácies Conglomerática foi considerada como tendo sido depositada em ambiente subaéreo ou subaquoso, correspondendo, provavelmente, a depósitos de leques aluviais. Como o alinhamento dessas litologias (NW-SE) é paralelo a falhas transcorrentes que ocorrem na área, sua origem pode estar relacionada a falhamentos ativos durante a sedimentação.

A Fácies Pelítica indicaria ambiente de águas calmas, sem influência de ondas.

As margas e calcilutitos basais da fácies carbonática teriam se depositado em zona de plataforma externa; os niveis de calcarenitos plaqueados teriam se depositado em águas calmas e relativamente profundas, como denotam as intercalações pelíticas e carbonáticas; os calcarenitos sugerem ambiente de águas rasas e agitadas, como evidenciado pelas laminações cruzadas, marcas onduladas e oóides presentes nessa unidade; a unidade de topo da Fácies Carbonática indica ambiente de águas rasas com exposição subaérea.

Segundo Magalhães (1989), as variações litológicas observadas nas diferentes unidades da Fácies Carbonática indicariam um grande ciclo de deposição progradante. Esse megaciclo pode ser dividido em ciclos menores, com mudanças no ambiente deposicional, como evidenciado pelas diferentes intercalações litológicas presentes. Os dolomitos teriam se originado através de dolomitização de carbonatos, em ambiente marinho próximo à praia, na interface água do mar/água meteórica.

A Fácies Psamo-Pelítica indicaria o afogamento da bacia em nova transgressão.

A bacia de deposição dessas litologias, à exceção dos conglomerados, teria um gradiente muito fraco e águas rasas, com um complexo de barras submersas em plataforma progradante.

Quanto ao aspecto metamórfico, os sedimentos do Grupo Bambuí são considerados por diversos autores como pouco ou nada metamorfisados, mas no geral é aceito que o grau de metamorfismo aumenta do centro para os bordos da bacia, em direção às faixas de dobramento, onde atingem a fácies xisto verde.

Scholl (1976), estudando o grau de cristalinidade das illitas nas litologias do Grupo Bambui, verificou a ausência de metamorfismo nos sedimentos próximos ao rio São Francisco, evidenciando um aumento gradual do mesmo em direção à Serra do Espinhaço.

Bonhomme (1976), também estudando a cristalinidade das illitas nos sedimentos do Grupo Bambui, em Minas Gerais, verificou que a influência do metamorfismo ligado ao 
Ciclo Brasiliano é mais intensa do que parece quando se observa a rocha macroscopicamente. Nas regiōes de João Pinheiro e Pirapora, identificou vermiculita de origem metamórfica e nos horizontes calcários da jazida de fosfato de Cedro do Abaeté encontrou "esmectita metamórfica". O autor situa em torno de $600 \mathrm{Ma}$ o evento metamórfico que afetou essas rochas. De toda a área estudada, apenas a região de Januária revelou-se "isenta de qualquer evento termo-tectônico sensivel".

Como se observou anteriormente, a possivel idade dos terrenos atualmente relacionados ao Grupo Bambui é discutida, baseada em diferentes critérios, desde os primeiros trabalhos, tendo se iniciado, segundo Freiberg (1932), com Liais (1872).

Bonhomme (1967) obteve, com datações $\mathrm{Rb} / \mathrm{Sr}$ em calcários pretos, uma idade de cerca de $620 \mathrm{Ma}$ em Januária, que corresponderia à fase principal do Ciclo Orogênico Brasiliano; seria um valor mínimo para a idade real do Grupo Bambuí, o que o coloca seguramente no Proterozóico Superior. As illitas ferromagnesianas de Cedro do Abaeté forneceram idades de $445 \pm 25 \mathrm{Ma}$, o que refletiria eventos posteriores ao Ciclo Brasiliano.

Baseando-se em estromatólitos que ocorrem no municipio de Sete Lagoas e que foram caracterizados como sendo do tipo Gymnosolenida, Marchese (1974) atribuiu ao Grupo Bambui idades entre 650 e $950 \mathrm{Ma}$, situando-o no Rifeano Superior.

Brito Neves et al. (1979), situam a deposição do Grupo Bambui entre 1,2 e 1,0 Ga, tendo sofrido deformação e metamorfismo entre 650 e $500 \mathrm{Ma}$, no Ciclo Brasiliano. Definiram ainda eventos pós-brasilianos, com ajustamentos finais de blocos, com idades variando entre 500 e $400 \mathrm{Ma}$.

Couto et al. (1981) obtiveram através de datações $\mathrm{Rb} / \mathrm{Sr}$ em rochas do Grupo Bambuí, uma seqüência de idades de $640 \pm 15,620 \pm 40$ e $590 \pm 40 \mathrm{Ma}$; valores esses interpretados como correspondendo a três eventos deposicionais do referido grupo.

Kawashita et al. (1987), utilizando das razöes ${ }^{87} \mathrm{Sr} /{ }^{86} \mathrm{Sr}$ nos carbonatos, estimaram idades de 680 e 570 Ma para a deposição de rochas carbonáticas.

Babinsky (1993) em sua tese de doutourado estabeleceu os procedimentos químicoanalíticos envolvidos na dataçäo de rochas carbonáticas pela metodologia $\mathrm{Pb} / \mathrm{Pb}$ e sua aplicação na determinação de idades de deposição e deformação dos carbonatos do Grupo Bambui na porção sul da bacia do São Francisco. As litologias aflorantes no extremo sul da área estudada foram consideradas pela autora como pertencentes à Formação Sete Lagoas (Costa \& Branco 1961). Amostras coletadas nas proximidades de Moema (MF-7), em rochas sem evidência de deformação mesoscópica, forneceram isócrona $\mathrm{Pb} / \mathrm{Pb}$, com idade de $686 \pm 69 \mathrm{Ma}$, considerada como representando a idade mínima de deposição dos carbonatos. Amostras coletadas em Pedreira da CAMIG situada 
na estrada Arcos-Pains forneceram idade de $520 \pm 53 \mathrm{Ma}$, considerada como correspondendo a uma época de rehomogeinização isotópica de $\mathrm{Pb}$, provavelmente relacionada aos estágios finais do Ciclo Brasiliano. Uma idade de $872 \pm 290 \mathrm{Ma}$, obtida em calcários afetados por tectonismo na estrada Pains-Arcos, foi julgada questionável. A autora considera que embora não existam dados conclusivos sobre a idade de deposição das rochas do Grupo Bambuí, sua deposição provavelmente ocorreu no Rifeano Superior, entre 950 e $650 \mathrm{Ma}$, em concordancia também com dados paleontológicos (acritarcas).

\section{2 - ESTRATIGRAFIA}

Estratigraficamente, o Grupo Bambui pertence ao Supergrupo São Francisco, como definido por Pflug \& Renger, em 1973.

Atualmente, duas divisões são as mais aceitas para o grupo. A estratigrafia proposta pelo Projeto RADAMBRASIL (1982), em seu relatório sobre a Folha Brasilia-SD.23, formaliza modificações na divisão estratigráfica proposta por Dardenne, em 1978 (Figura 2). Exclui a Formação Jequitaí da base do Grupo Bambui, como anteriormente sugerido por Oliveira (1967) e Couto \& Bez (1981), situando-a no Grupo Macaúbas. As demais formaçōes, à exceção da Três Marias, são reunidas sob a denominação de Subgrupo Paraopeba. Como unidade basal do Grupo Bambui, estariam corpos conglomeráticos delgados e descontínuos, como os denominados Conglomerado Samburá (Miranda 1951) e Conglomerado Carrancas (Costa \& Branco 1961), entre outros.

Schobbenhaus et al. (1984), baseados principalmente nos trabalhos de Costa \& Branco (1961) e Dardenne (1978), mantêm no Grupo Bambui a Formação Jequitaí como unidade basal, seguida pelas formações Sete Lagoas, Serra de Santa Helena, Lagoa do Jacaré e Serra da Saudade, que constituem o Subgrupo Paraopeba; a Formação Três Marias, constitui a unidade de topo do grupo.

Neste trabalho é adotada a estratigrafia proposta pelo Projeto RADAMBRASIL (1982), por se considerar que o aspecto paleoclimático, que caracteriza a Formação Jequitaí, não é compativel com o ambiente de sedimentação característico de rochas carbonáticas.

\section{Subgrupo Paraopeba}

-Conglomerado basal - É composto por corpos descontinuos e de pequena extensão de conglomerados polimíticos, de aspecto diamictítico, e arenitos conglomeráticos. Foram 
descritos em vários locais, recebendo denominações próprias, como Conglomerado Samburá (Miranda 1951), descrito na região de Bambuí, e Conglomerado Carrancas (Branco \& Costa 1961), entre outros.

-Formação Sete Lagoas (Costa \& Branco 1961) - É composta predominantemente por calcários e dolomitos. Margas e pelitos no geral ocorrem subordinadamente e constituem corpos lenticulares de dimensões variadas. As rochas carbonáticas ocorrem como horizontes contínuos, ou localmente, como corpos lenticulares.

-Formação Serra de Santa Helena (Costa \& Branco 1961) - Constituida predominantemente por pelitos, com siltitos, argilitos, ardósias e folhelhos esverdeados; secundariamente, ocorrem intercalações lenticulares de calcário cinza escuro e margas.

-Formação Lagoa do Jacaré (Costa \& Branco 1961) - É composta predominantemente por calcários pretos a cinza compondo extensos horizontes. Apresenta niveis oolíticos ricos em matéria orgânica e intercalações de margas e pelitos, no geral siltitos e folhelhos.

-Formação Serra da Saudade (Costa \& Branco 1961) - Constitui a unidade de topo do Subgrupo Paraopeba, com siltitos, folhelhos e ardósias de cor esverdeada. Localmente, contém pequenas lentes de calcário cinza claro e margas.

\section{Formação Três Marias}

-Formação Três Marias (Costa \& Branco 1961) - É constituida por siltitos, arcóseos e arenitos arcoseanos de cor cinza esverdeado. O contato com a formação sotoposta é concordante, freqüentemente de caráter transicional.

\section{3 - EVOLUÇÃO TECTONO-SEDIMENTAR}

Os principais autores que tratam da evoluçäo tectono-sedimentar da Bacia do São Francisco não são unânimes com relação ao tipo de bacia que representaria, e seu processo evolutivo.

Kiang et al. (1988), sugerem que a Bacia do São Francisco, pode ser comparada, em principio, a foldthrust belts e complexos de bacias foreland. Sugerem que na fase 
distensiva inicial da evolução da bacia, no Proterozóico Médio (Rifeano), teriam se depositado as seqüências sedimentares dos grupos Paranoál Canastra, Supergrupo Espinhaço e talvez parte do Grupo Bambuí.

Com a mudança da polaridade, no Brasiliano (Vendiano), teria havido uma inversão do regime tectônico, com desenvolvimento de bacias foreland, induzidas por flexuras resultantes de reajustamento isostático. Ao menos parte, senảo todo o Subgrupo Paraopeba, teria sido depositado nessa fase, em regime extensional. A Formação Três Marias constituiria o único registro sedimentar depositado em resposta à tectônica colisional.

Alkmin et al. (1989), não concordam inteiramente com as idéias de Kiang et al. (op. cit.). Consideram que as unidades basais do Supergrupo São Francisco, à exceção do Grupo Macaúbas, que teria sido depositado sob influência glacial, representariam expansöes das bacias marginais ao Cráton do São Francisco. A inversão parcial da bacia teria se dado quando da geraçäo das faixas de dobramento, durante o Ciclo Brasiliano.

Os autores dividem a porção sul da bacia em 4 compartimentos, com evolução estrutural distinta. Os compartimentos de leste e oeste são marginais ao cráton e sofreram influência das faixas de dobramentos, enquanto os compartimentos centrais foram poupados da deformação.

Acreditam que um possivel comportamento da Bacia do São Francisco como uma bacia do tipo foreland, poderia estar registrado apenas pelos sedimentos da Formação Três Marias.

\section{4 - LOCALIZAÇÃO DAÁREA PESQUISADA E GEOLOGIA LOCAL}

A área de estudo situa-se na região do alto rio São Francisco, na porção sudoeste do estado de Minas Gerais, entre as latitudes $20^{\circ} 15^{\prime}$ e $20^{\circ} 30^{\prime}$ sul e longitudes $45^{\circ} 30^{\prime}$ e $45^{\circ} 45^{\prime}$ oeste (Figura 3 ).

$\mathrm{Na}$ regiäo de Arcos, as rochas carbonáticas prolongam-se para norte, ao longo do vale do rio São Francisco. A oeste/sudoeste os sedimentos do Grupo Bambui são limitado pelos metassedimentos do Grupo Canastra (Barbosa 1955), do Proterozóico Médio; a sul, pela seqüência vulcano-sedimentar tipo greenstone belt de Piumhi, de idade arqueana, e por metamorfitos do Grupo Araxá (Barbosa 1955), do Proterozóico Médio; a leste, já na área trabalhada, o limite é feito com terrenos gnáissico-migmatíticos, de idade arqueana.

Estruturalmente, as rochas do Grupo Bambui na porção sudoeste da Bacia do São Francisco apresentam "um acervo estrutural dominado por falhas inversas/de empurrão e 


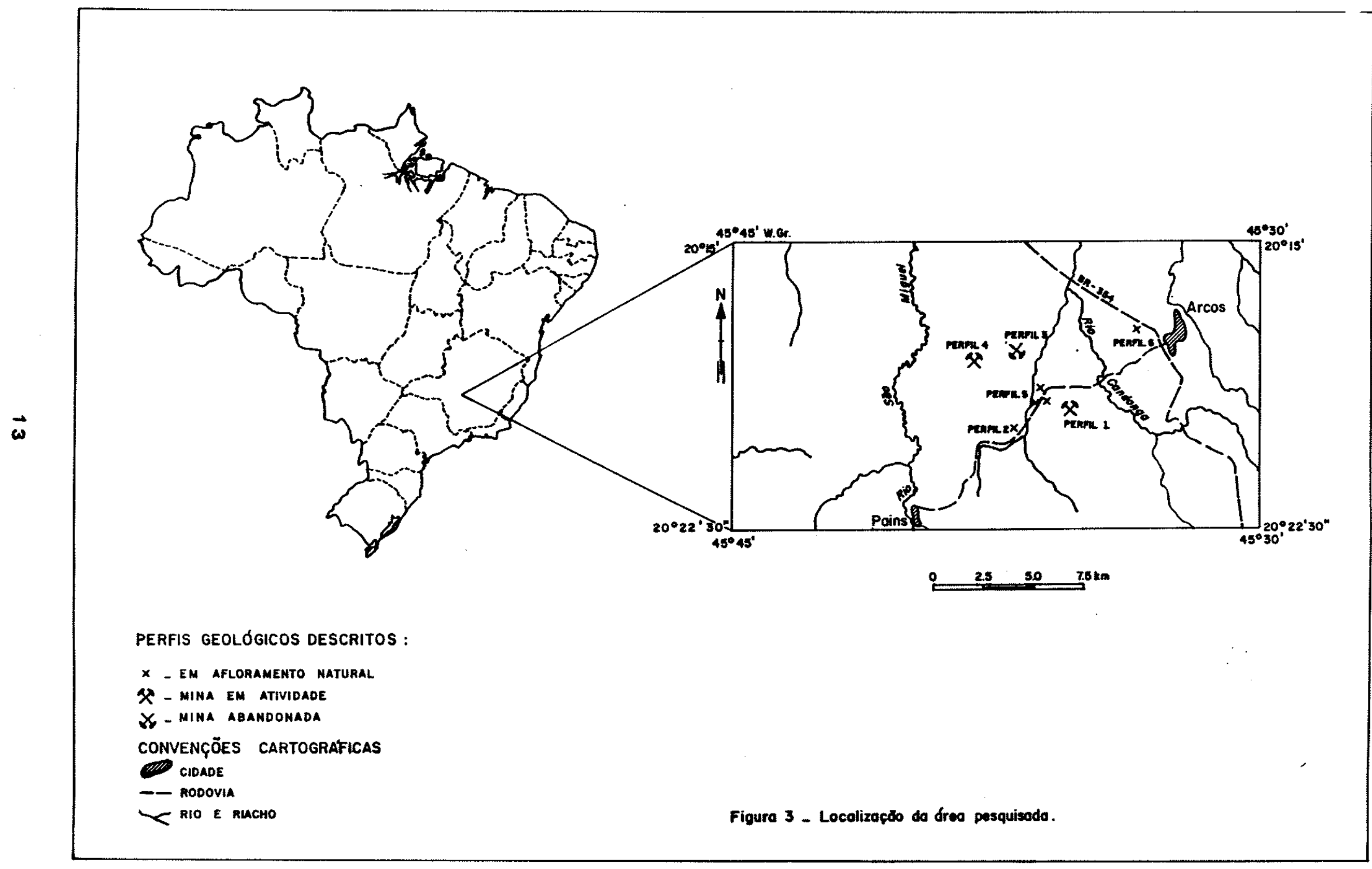


de rejeito direcional", resultantes de esforços tectônicos que atuaram de oeste para leste, segundo Magalhães (1989). O autor individualiza na área os Domínios Estruturais 1 e 2 , separados por uma Zona de Transição. O Dominio 1 acha-se afetado por sistemas de falhas transcorrentes; a Zona de Transição corresponde a uma faixa de direção Norte-Sul entre os domínios 1 e 2 e é caracterizada por significativo decréscimo na magnitude da deformação. No Dominio 2, as rochas no geral não são afetadas tectonicamente, observando-se apenas suaves ondulações locais.

A área estudada situa-se em parte na Zona de Transição e em parte no Domínio 2 (Figura 4). 


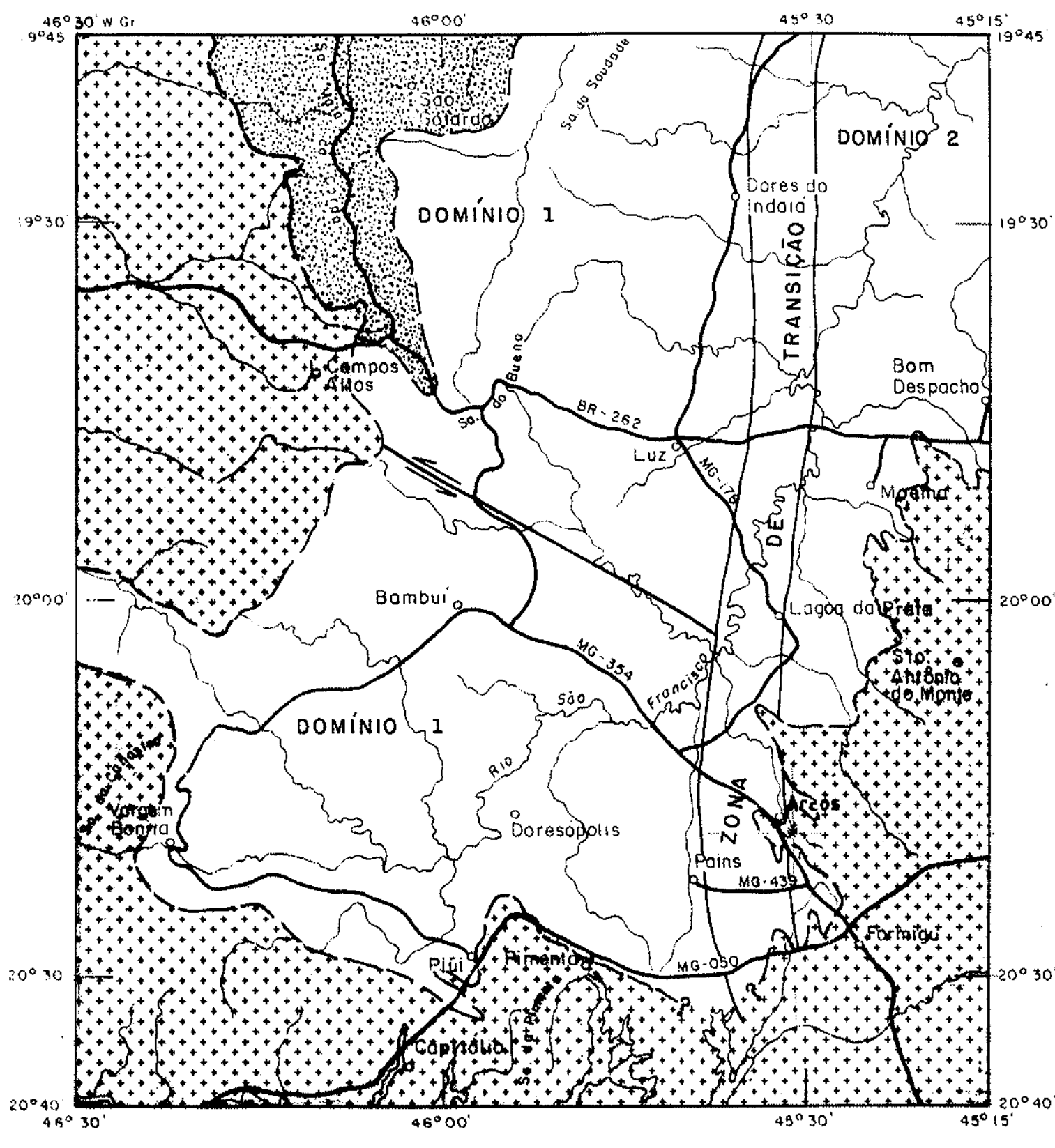

LEGENDA

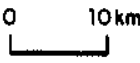

Formação Mato da Corda $(K)$

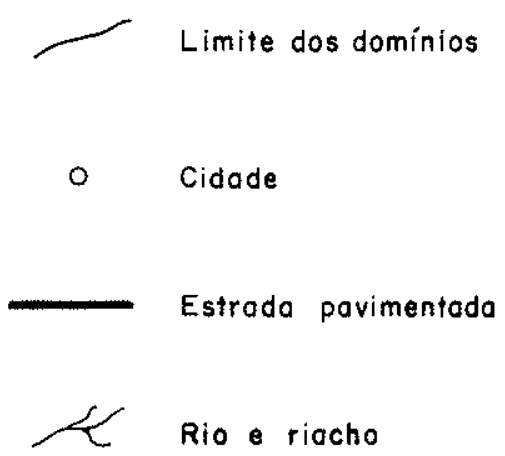

Figura 4 - Esboco geológico do regiäo do alto Rio Sõo Francisco, dividido em domínıs estruturais (Magathöes 1989). 


\section{3 - MATERIAIS E MÉTODOS}

No decorrer das pesquisas foram desenvolvidos trabalhos de campo, de laboratório e finaimente o tratamento dos dados coletados.

Os trabalhos de campo constaram basicamente do levantamento de seções de rochas carbonáticas expostas nas proximidades da cidade de Arcos: ao longo das rodovias Arcos-Pains (1) e Arcos-Iguatama (1), em pedreiras da COMIG (3) e na Mina da Bocaina-CSN, totalizando 6 seçöes estudadas. A seção geológica acessível mais completa da área é a da Mina da Bocaina (CSN).

As seçöes foram levantadas nas escalas 1:50 e/ou 1:100, verticais. Quando possivel, as seções foram medidas; nos demais casos as espessuras foram estimadas.

Na maioria das vezes, as seçōes foram levantadas em locais distantes entre si de até dezenas de metros, mas sempre acompanhando niveis estratigráficos de referência.

Nos levantamentos efetuados, foram identificados os diferentes tipos litológicos, as estruturas sedimentares, organossedimentares e as feiçōes estruturais e de compactação. Variações de cor, de espessura dos estratos e os tipos de contato também foram anotados.

A seção levantada na Mina da Bocaina (Companhia Siderúrgica Nacional - CSN), é referenciada no texto como Perfil 1 (Prancha 1).

As seções geológicas em áreas da COMIG, são denominadas de Perfil 2 (área de afloramento na entrada da companhia e pequena área contigua de lavra desativada); como Perfil 3 a mina grande, abandonada e Perfil 4 a área atualmente em lavra da COMIG (Pranchas 1 e 2).

A seção geológica constituída por pequenos afloramentos descontínuos na estrada Arcos-Pains foi denominada de Perfil 5 e o pequeno afloramento de margas na BR-354, nas proximidades de Arcos, constitui o Perfil 6.

Os trabalhos de laboratório constaram basicamente de estudos petrográficos; análises palinológicas e de Raios $\mathrm{x}$ foram efetuadas muito subordinadamente.

Para estudo petrográfico, foram confeccionadas e analisadas cerca de 300 lâminas deigadas.

Visando a identificação de microfósseis, algumas amostras foram submetidas à preparação palinológica. As amostras analisadas pertencem às unidades basais aflorantes nos Perfis 1, 2 e 3, e foram selecionadas por apresentarem evidências de constituirem construções microbianas, passiveis de conterem microfósseis que pudessem indicar a 


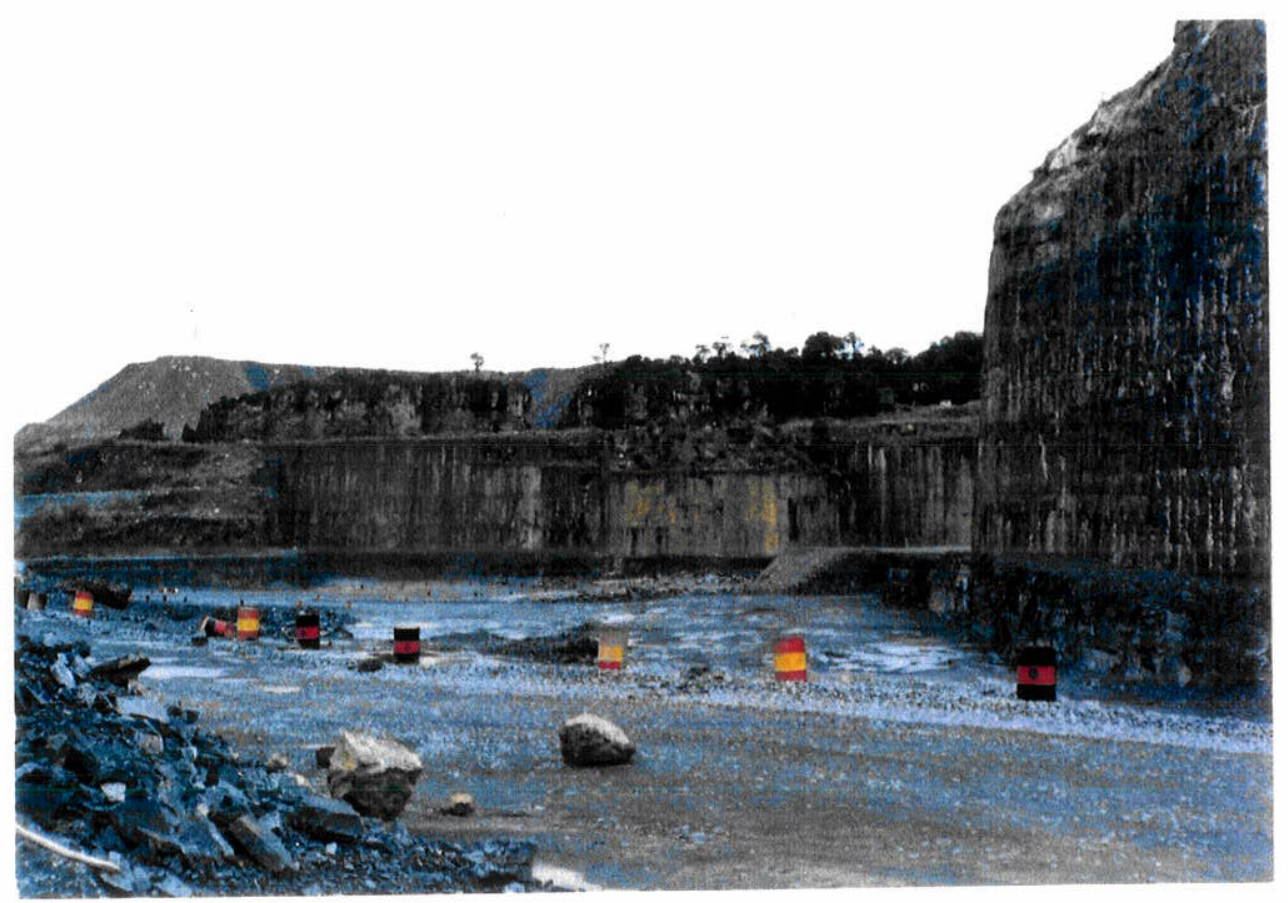

Foto 1 - Vista geral da Mina da Bocaina - CSN - PERFIL 1

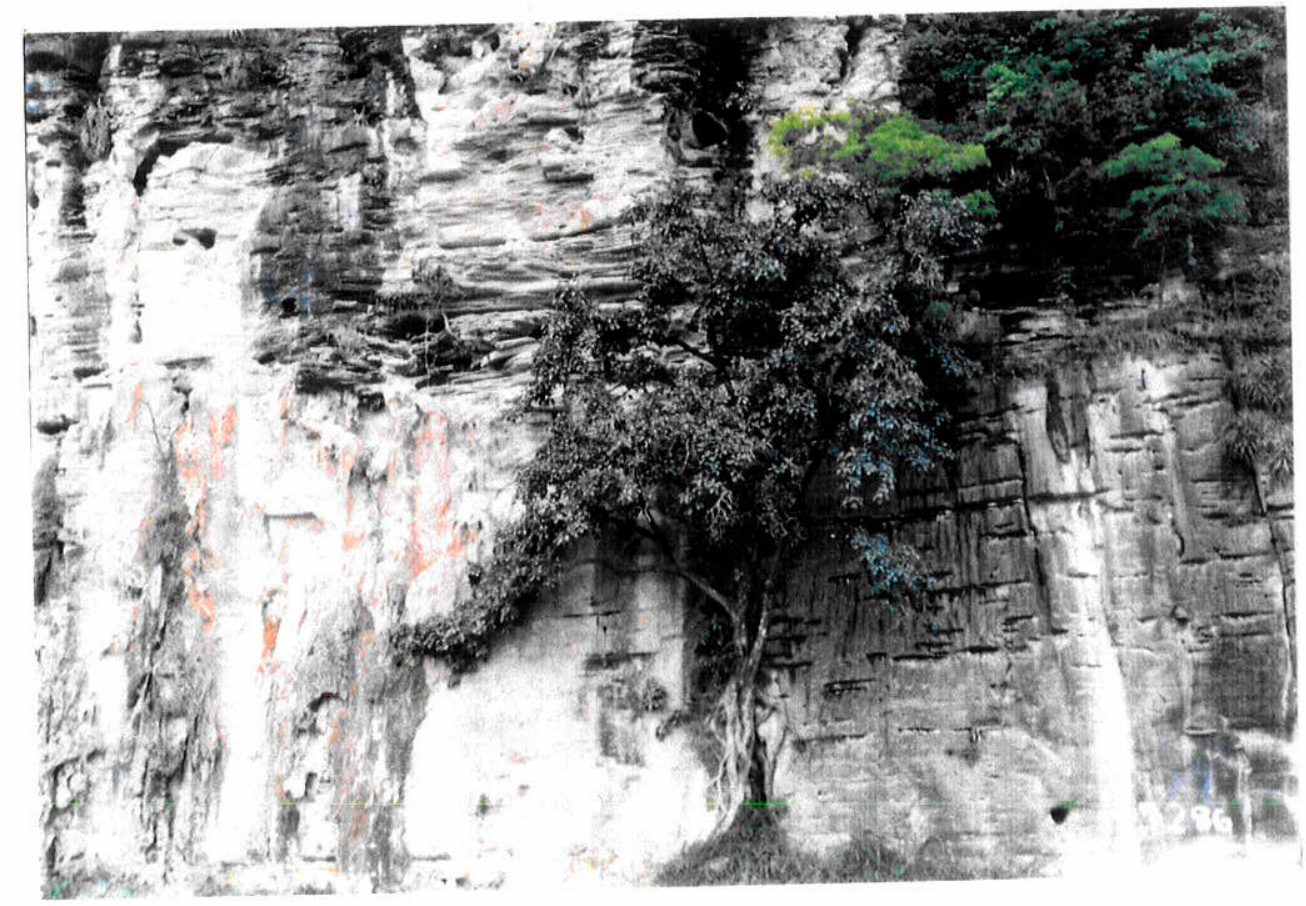

Foto 2 - Vista geral do afloramento da entrada da COMIG. - PERFIL 2 


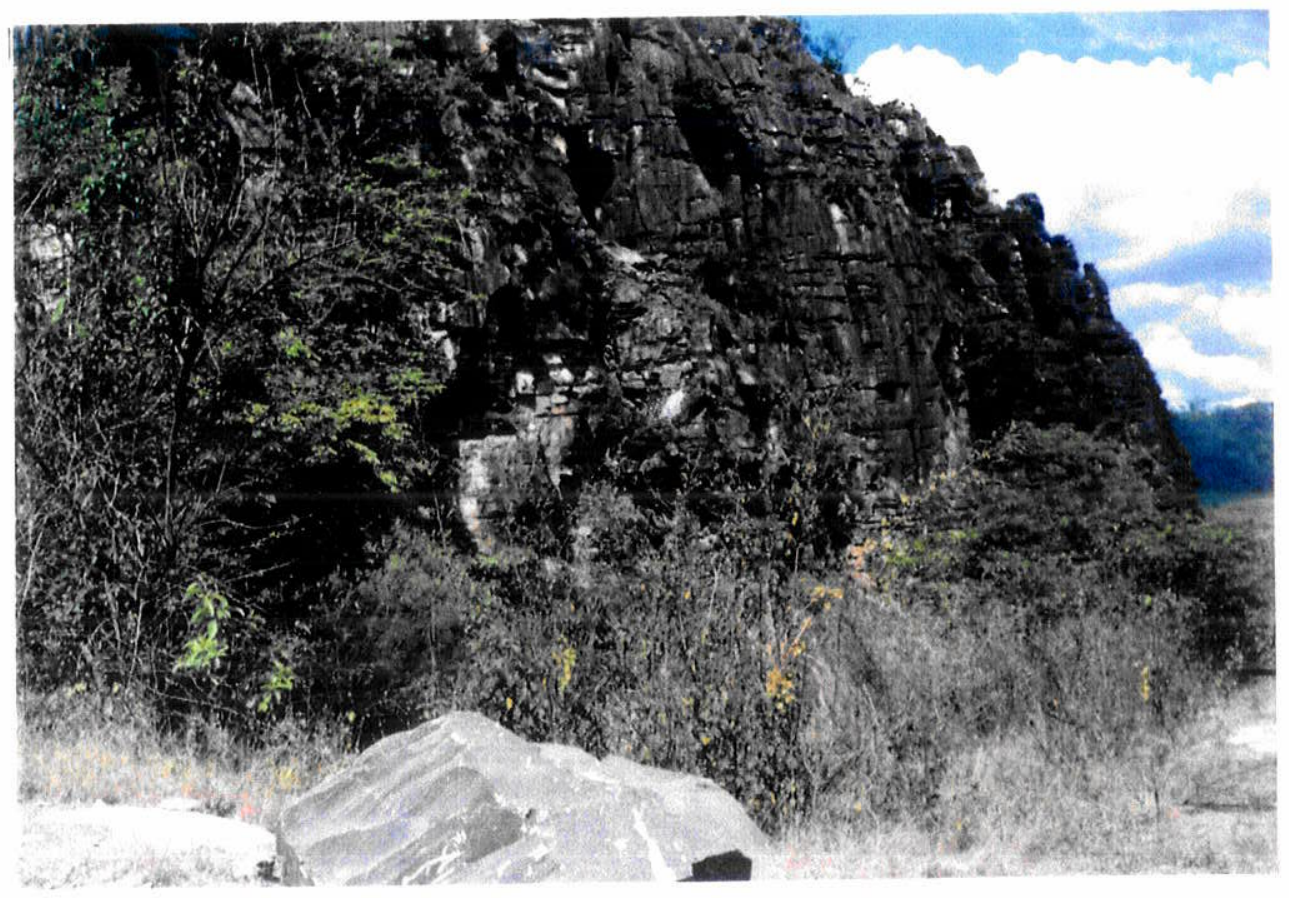

Foto 1 - Vista geral da mina abandonada da COMIG. - PERFIL 3

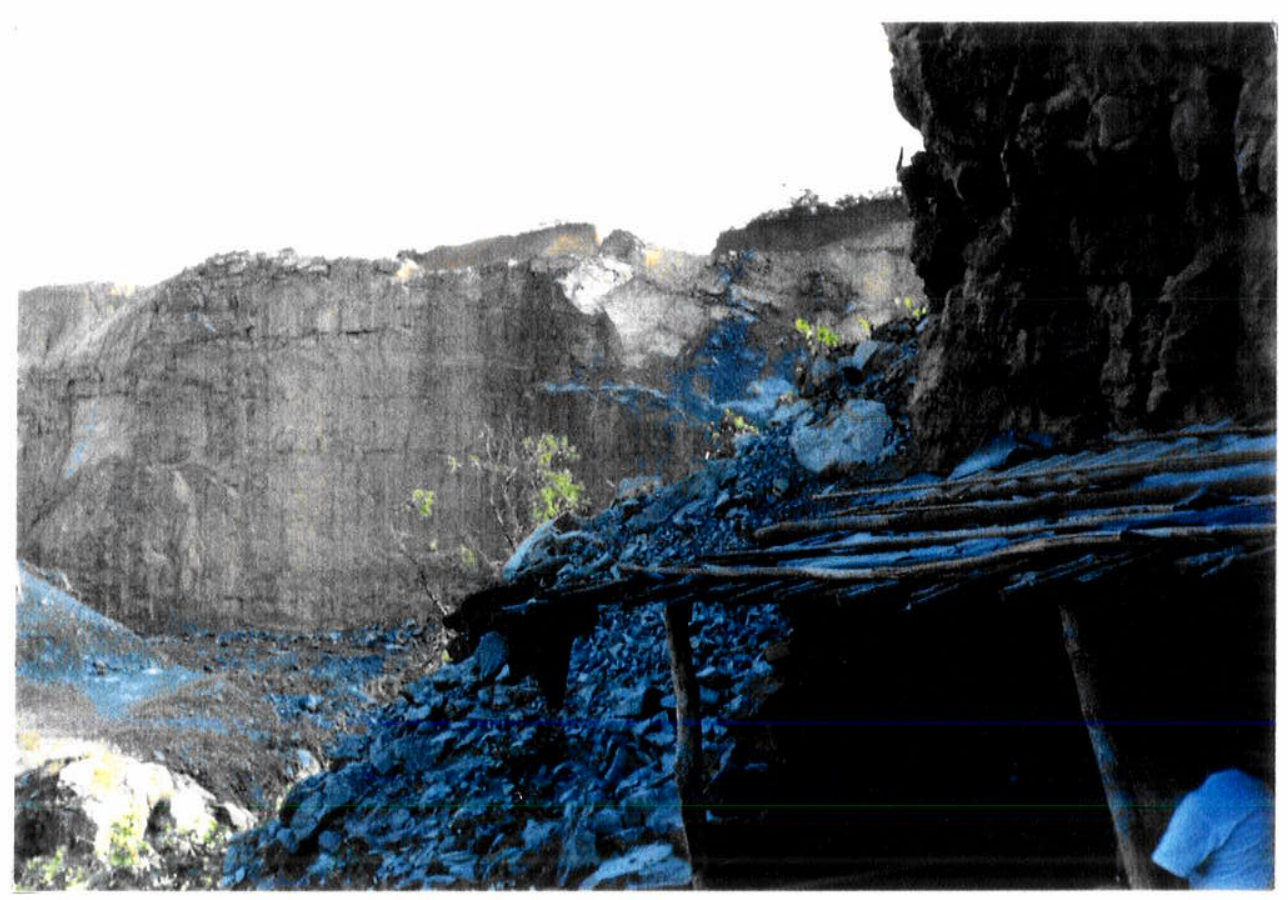

Foto 2 - Vista geral da mina em atividade da COMIG. - PERFIL 4 
idade de deposição das seções estudadas. As análises palinológicas foram efetuadas pela Dra. Norma Maria da C. Cruz.

Análises por Difratometria de Raios $\mathrm{X}$ foram efetuadas pelo geólogo Nelson da Silva Gondim e tiveram por objetivo a identificação dos minerais de argila presentes nos calcários silicosos da base das seções aflorantes e lentes carbonosas que ocorrem no Perfil 1.

A Dra. Norma M. da C. Cruz e o geólogo Nelson da S. Gondim são técnicos do Laboratório de Mineralogia - LAMIM, da CPRM.

Procurou-se também estudar os estromatólitos, que ocorrem em grande quantidade, sob o aspecto morfológico e de microestrutura, com vistas à identificaçảo do ambiente onde se desenvolveram.

Com as amostras de estromatólitos, foram confeccionadas no Centre Géologique et Géophysique - CGG-CNRS, na Universidade de Montpellier II, França, seçōes delgadas com maior superficie de observação, o que possibilitou a realização de estudos de sua microestrutura, efetuados sob orientação da Dra. Janine Bertrand-Sarfati.

As construções microbianas não estromatoliticas também foram estudadas, com observações de campo e análise da microestrutura em lâminas delgadas.

As lâminas delgadas e os resíduos orgânicos das preparaçōes palinológicas achamse arquivadas na Companhia de Pesquisa de Recursos Minerais, escritório Rio de Janeiro.

Para a identificaçäo da dolomita foi efetuado teste de coloração com Alizarina Red-S em $\mathrm{HCl}$ a $2 \%$.

A freqüência de dolomita e aloquímicos em lâminas delgadas foi estimada semi-quantitativamente, através da Comparison Chart for Visual Percentage Estimation (Terry \& Chillingar 1955 apud Scholle 1978).

Para a classificação granulométrica dos sedimentos foi utilizada a tabela de UddenWentworth, contida em Tucker (1982).

As microfotos apresentadas foram obtidas a partir de lâminas delgadas cortadas perpendicularmente ao acamamento geral da rocha, e salvo indicação em contrário, estão em posição normal, isto é, com o topo para cima.

As legendas utilizadas nos perfis, blocos-diagramas e pranchas são as seguintes:

- bioherma

- biostroma

// - laminação plano-paralela

i) - laminação plano-paralela a ondulada

«e- laminação cruzada 
/ - estratificação cruzada planar

- estratificação cruzada por ondas

$\smile$ - estratificação cruzada acanalada

น- marca ondulada

$\wedge$ - gradação normal

$\checkmark$ - gradação inversa

- estruturas de compactação

- gretas de contração

$\nabla$-brechas de dissolução ( brechas de colapso)

* - evaporitos

- lentes de sílex ou níveis silicificados

- lentes carbonosas

$W$ - wackestone; $P$ - packstone; $G$ - grainstone; pi -pirita

ag - argila; st - silte; af - areia fina; am - areia média; agr - areia grossa;

>a - granulação maior que areia

L.N.- luz natural X.N.- luz sob nicóis cruzados P.G.- placa de gipso 


\section{4 - DESCRIÇÄO DAS ROCHAS CARBONÁTICAS}

\section{1 - COMPONENTES DOS CARBONATOS DETRITICOS}

De modo geral, as rochas carbonáticas detríticas são compostas por gräos aloquímicos, matriz e cimento. Neste item serão discutidos os grãos aloquímicos e a matriz que constituem as rochas carbonáticas do Grupo Bambuí. 0 cimento será discutido no ítem reservado à diagênese.

Entre os principais tipos de grãos aloquímicos ou partículas carbonáticas que constituem 0 arcabouço das rochas estudadas, estão pelóides, intraclastos, oólitos, oóides e bioclastos.

\subsection{1 - Pelóides}

Pelóides são corpos arredondados, esféricos a elípticos ou agregados ovóides compostos por calcita criptocristalina. Não apresentam estrutura interna e a designação abrange gräos que tenham essas características, independente de sua origem (Folk 1962, Bathurst 1975). O termo foi cunhado por McKee (apud Bathurst 1975) e inclui gräos situados nas faixas silte $e$ areia. Nas fraçöes finas, nem sempre o contorno dos grãos é nítido, devido ao tamanho reduzido dos pelóides.

Uma das dificuldades no trato com pelóides é o estabelecimento de sua origem. Podem ser derivados de intraclastos que por abrasão foram reduzidos a pelóides, podem representar microncólitos sem estrutura interna ou mesmo células de microorganismos. Grãos sem limites definidos podem ainda ser derivados de aglutinação de micrita. $O$ fato de os carbonatos encontrarem-se freqüentemente recristalizados e compactados dificulta o estabelecimento da origem dos pelóides.

$\mathrm{Na}$ área estudada, os pelóides são freqüentes e nem sempre facilmente caracterizáveis, pois acham-se em grande parte neomorfizados (Prancha 3, fotos 1 e 2).

Nos calcissiltitos, os pelóides freqüentemente apresentam contornos nítidos, o que sugere que talvez em parte sejam constituidos por partículas orgânicas remanejadas de niveis bioconstruídos.

Calcissiltitos e calcarenitos são ainda eventualmente constituídos por pelóides micríticos muito escuros, bem arredondados, de contornos nítidos e freqüentemente neomorfizados. Poderiam ter sido originados por microorganismos, pois freqüentemente ocorrem associados a estromatólitos. 


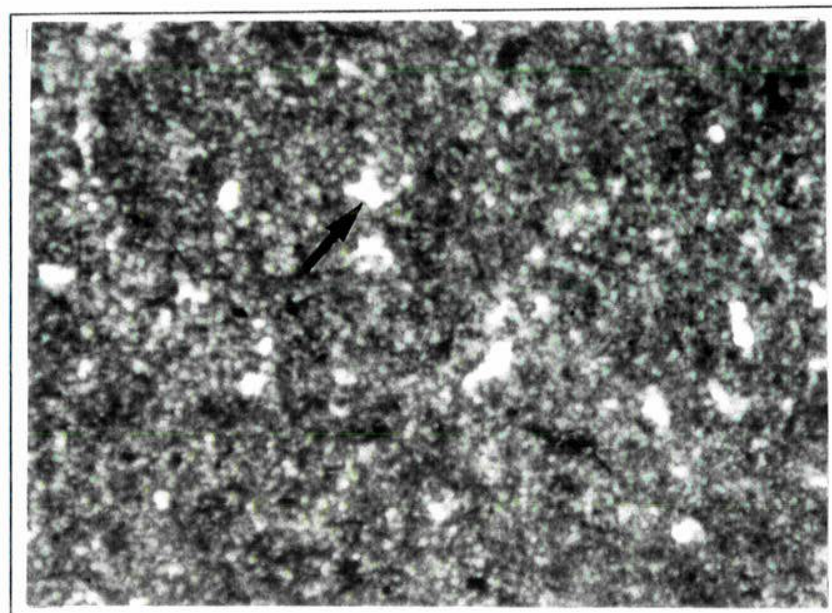

Foto 1 - Fotomicrografia de calcissiltito peloidal, onde se observa dissolução de grãos e abertura de cavidades que são preenchidas por calcita espática (seta). X.N. 30x

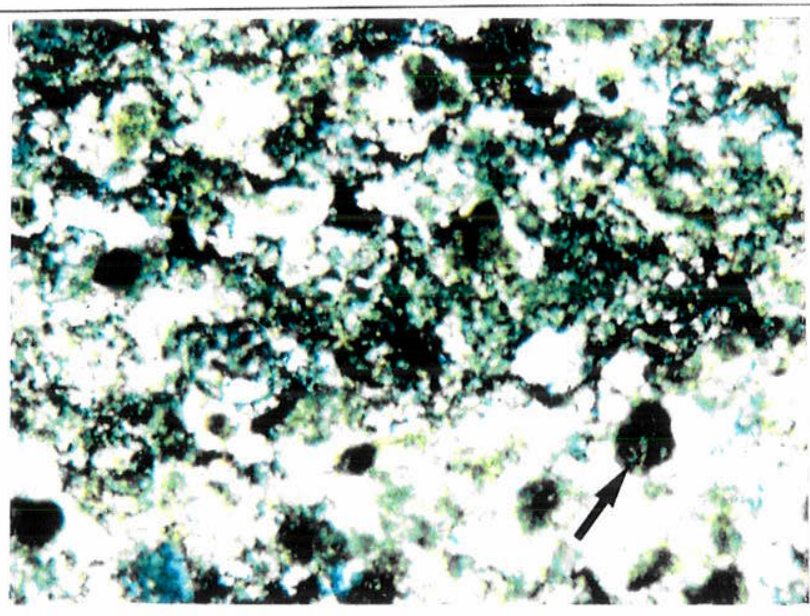

Foto 2 - Fotomicrografia de pelóides micríticos que estão parcialmente neomorfizados (seta). X.N. 70x

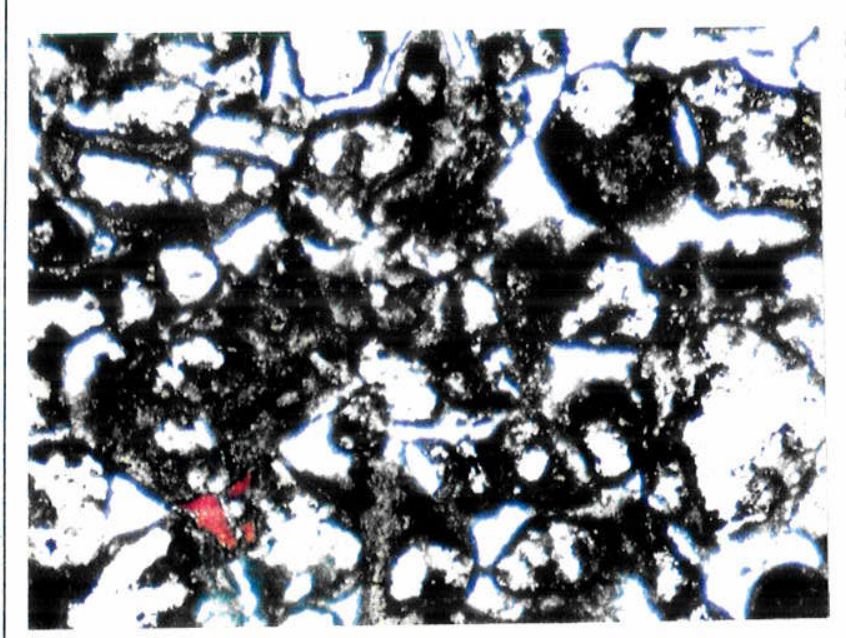

Foto 3 - Fotomicrografia de intraclasto parcialmente silicificado. A área em vermelho é calcita espática, por coloração com alizarina. L.N. 20x

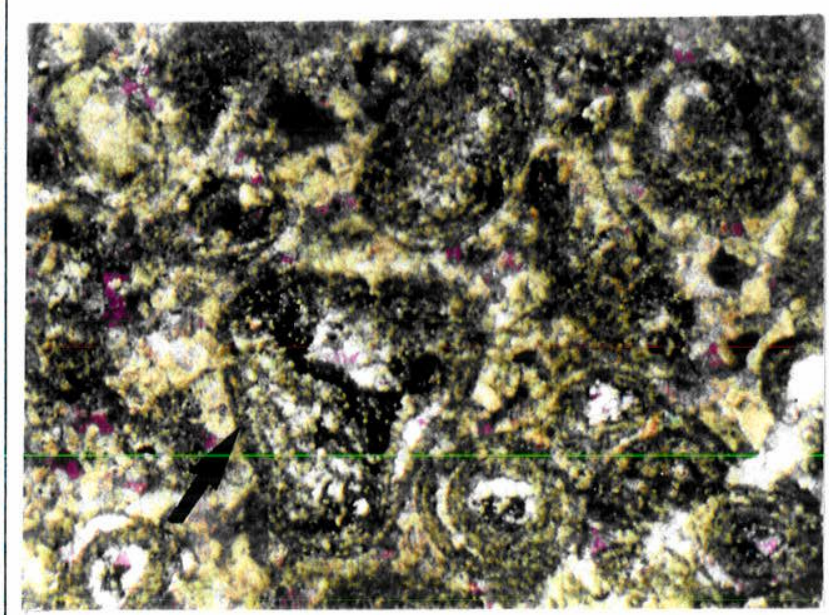

Foto 5 - Fotomicrografia de intraclastos oolíticos semelhantes a grapestones (seta); presença de oólitos múltiplos. P.G./L.N.30x

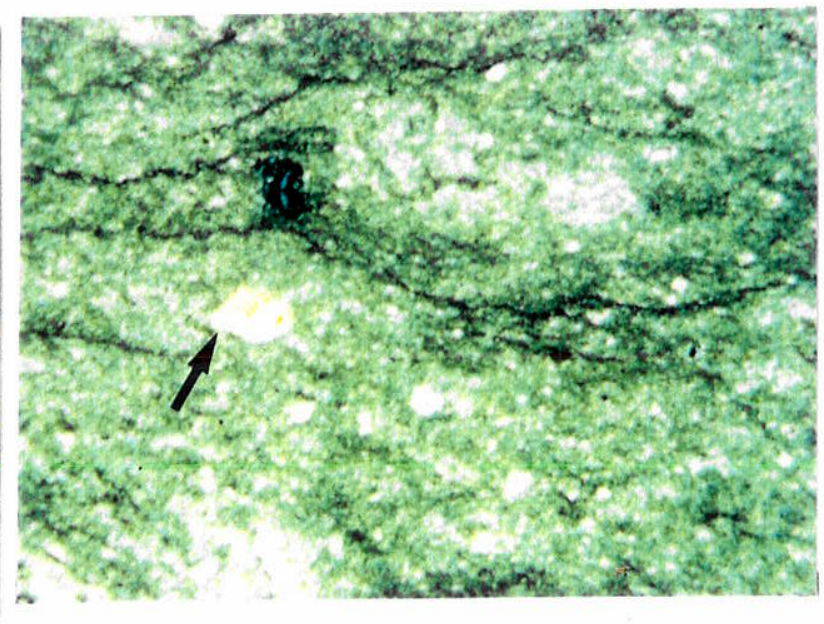

Foto 6 - Fotomicrografia de lama carbonática com estilólitos, evidenciando compactação; observa-se albita neoformada (seta). X.N. 25x 
Calcarenitos são também, em parte, constituídos por pelóides resultantes da abrasão de intraclastos.

\subsection{2 - Intraclastos}

Termo cunhado por Folk (1962), para descrever fragmentos de sedimentos carbonáticos penecontemporâneos, geralmente pouco consolidados, que foram erodidos de áreas adjacentes e redepositados para formar novo sedimento. Intraclastos podem se formar também sob condiçōes mais severas, como quando sedimentos já soterrados alguns decímetros abaixo do leito oceânico são arrancados, no geral por ação de eventos de tempestades. Assim, o termo intraclasto abrange o espectro completo de sedimento contemporâneo retrabalhado, desde que não se trate de rocha consolidada.

Segundo a concepção de Folk (op. cit.), o termo intraclasto implica que determinado sedimento tenha sido retrabalhado e redepositado em áreas próximas. Quanto à granulometria, podem variar de areia muito fina a matacöes. Podem ser calciticos ou dolomíticos.

Um tipo especial de intraclasto é constituido por agregados do tipo grapestones (Illing 1954 apud Folk 1962), compostos por grãos aglutinados que lembram pequenos cachos de uva, origem do têrmo grapestone. Quando remobilizados e transportados, esses agregados comportam-se como intraclastos.

Os intraclastos observados não apresentam deformação plástica e são constituídos principalmente por calcissiltitos maciços ou laminados, e fragmentos de calcarenito oolítico ou intraclástico (Prancha 3, fotos 3 e 4). Alguns intraclastos apresentam-se encurvados. Ocorrem ainda intraclastos policíclicos, derivados de calcirruditos retrabalhado, bem como raros grapestones (Prancha 3, foto 5).

\subsection{3 - Oólitos}

Os oólitos são grãos aloquímicos, caracterizados por serem compostos por envelopes ou capas concêntricas, nítidas e bem definidas, de composição carbonática e núcleo de composição variável. Quanto à forma, podem ser esféricos ou elipsoidais. Não apresentam estruturas biogênicas, ou as mesmas constituem apenas uma pequena parte das camadas externas do oólito (Tucker \& Wright 1990).

Alguns oólitos apresentam-se bem formados, com capas concêntricas bem desenvolvidas, outros são oólitos superficiais; podem não apresentar núcleo identificável, 
ou terem o núcleo constituido por vários fragmentos. Observa-se ainda oólitos polinucleados (Prancha 3, foto 5), e podem eventualmente ser micríticos ou terem sido micritizados (Prancha 4, fotos 1 e 2).

Em alguns oólitos, o padrão de envelopes concêntricos é cortado por estrutura fibrorradiada bem desenvolvida, não apresentam núcleo diferenciado, têm microestrutura radiada e sob nicóis cruzados exibem cruz negra; são esferulitos.

Os oólitos no geral estão neomorfizados e nem sempre bem preservados; em alguns casos, observa-se apenas vestígios dos envelopes concêntricos (Prancha 4, foto 3). Podem também estar deformados, quebrados, ou terem sofrido dissolução parcial com substituição de algumas capas por sílica (Prancha 3, foto 5; Prancha 4, fotos 1 e 2).

Embora a literatura geológica de língua inglesa utilize a designação colite para a rocha composta por ooids, o uso corrente da palavra oólito na língua portuguesa para designar a partícula, fez com que essa terminologia fosse adotada neste trabalho.

\subsection{4 - Oóides}

Esta terminologia foi adotada para grãos aloquímicos muito bem arredondados, de seção esférica ou ovalada, mas sem capas concêntricas observáveis, por estarem dolomitizados, ou terem sofrido dissolução, com posterior preenchimento por quartzo. Seriam oólitos presumiveis (Prancha 4, foto 4).

\subsection{5 - Oncólitos}

Oncólitos são grãos que exibem laminaçöes concêntricas, freqüentemente irregulares, consideradas como de origem biológica. Foram observados muito raramente; no geral observou-se apenas vestígios de aloquímicos muito recristalizados que sugerem oncólitos.

Como no caso de oólitos, a literatura inglesa utiliza o termo oncolite para a rocha e oncoids para os grãos; mas devido ao uso generalizado, no Brasil, da palavra oncólito designando a partícula, esta terminologia será mantida.

\subsection{6 - Bioclastos}

Como bioclastos, foram considerados todos os fragmentos derivados de bioconstruçōes ou de presumivel origem biológica. Embora o termo bioclasto, neste 


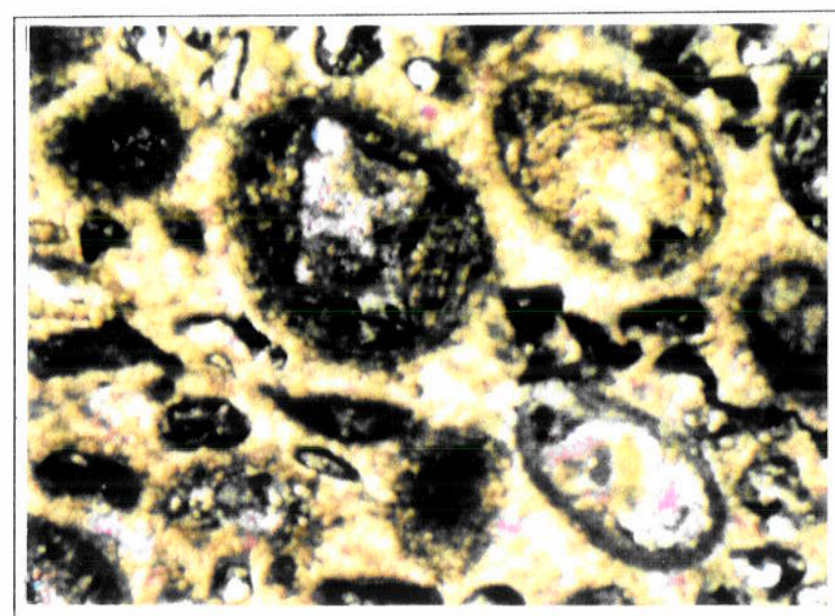

Foto 1 - Fotomicrografia de oólitos predominantemente micríticos ou micritizados, com capas irregulares; áreas com substituição por microquartzo.

P.G./L.N. 25x

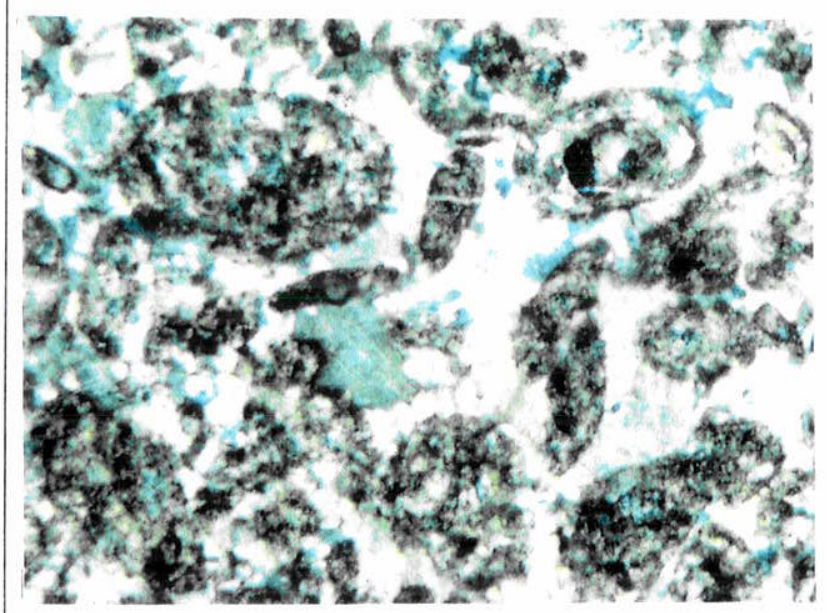

Foto 3 - Fotomicrografia de ólitos neoformizado vestígios das capas concêntricas X.N. 30x
com

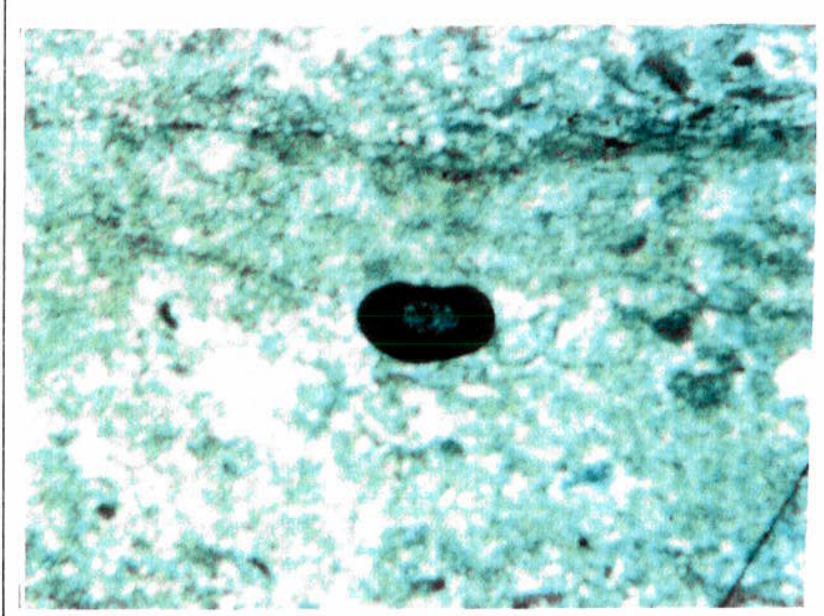

Foto 5 - Fotomicrografia de oóide micrítico. X.N. 30x

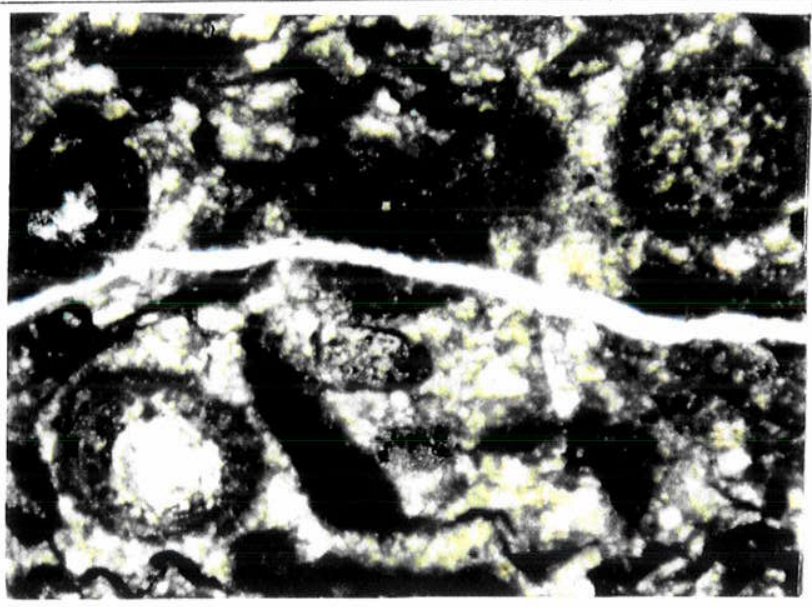

Foto 2 - Fotomicrografia de oólitos micríticos, ou que foram micritizados; deformação e fraturamento, com fratura aberta preenchida por calcita espática. L.N. $25 x$

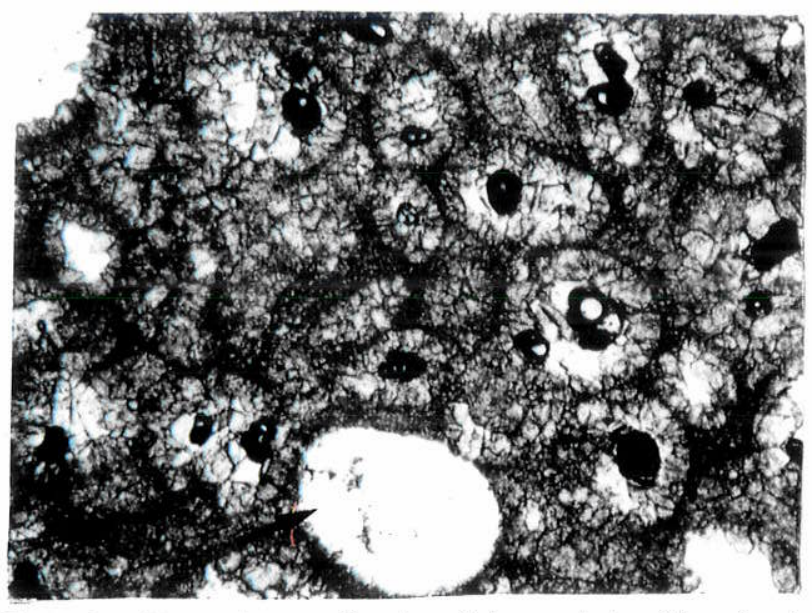

Foto 4 - Fotomicrografia de oóide; a dolomitização é responsável pela obliteração da textura original; notar silicificação parcial ou total de grãos por megaquartzo (seta). L.N. $25 x$

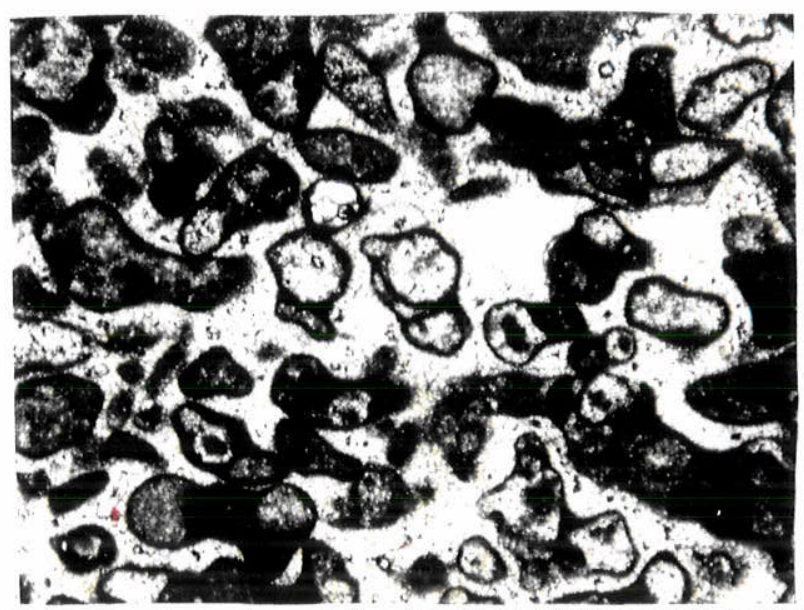

Foto 6 - Fotomicrografia de microfitólitos que foram dolomitizados de forma mímica, com preservação da estrutura original dos grãos. X.N. 35x 
trabalho seja utilizado com conotação algo diferente da utilizada em rochas fanerozóicas, quando se refere a fragmentos de organismos com estrutura calcária, quitinosa ou silicosa, a sua aplicação visou distinguir componentes bioderivados, de intraclastos.

Bioclastos de calcário microbiano críptico: São bioclastos micríticos, derivados do calcário microbiano críptico, definidos por Riding (1991) como depósitos microbianos com microfábrica micrítica, grumosa, peloidal ou espática, mas sem feiçōes macroscópicas distintivas. $O$ autor ressaita ainda que esses calcários podem apresentar traços de filamentos e que devido à ausência de macrofábrica, devem ser interpretados em função de sua microfábrica (Prancha 5, foto 1).

Bioclastos de estromatólitos: Ocorrem muito raramente, associados a estromatólitos (Prancha 5, fotos 4 e 6).

Bioclastos a Microfitólitos: o termo Microfitólito (Microphytolite) foi utilizado neste trabalho segundo o conceito adotado por Swett \& Knoll (1985). Originalmente o termo teria sido utilizado por paleontólogos soviéticos para designar uma grande variedade de grãos carbonáticos, alguns dos quais receberam denominação binomial, Lineana, e foram utilizados em bioestratigrafia; englobaria oncólitos e Catagraphes (Maslov 1953), como consta do glossário contido em Walter (1976). Catagraphs (Maslov 1953 apud BertrandSarfati 1972) são corpúsculos carbonáticos, de dimensöes diversas, globulosos, isolados ou aglutinados, que não apresentam envelopes concêntricos; são considerados como derivados de atividade algal. Tucker (1990), utiliza o termo Catagraph com a conotação de grãos algáceos calcificados. Apresentam dimensões variando de areia a cascalho e originalmente incluem oólitos, oncólitos, grapestones, algal lumps e outros intraclastos de origem discutivel. Foram interpretados (Swett \& Knoll op. cit.) como sendo geneticamente compostos, tendo sido gerados pela associação de processos microbianos e sedimentares, tais como o crescimento de bactérias ou cianobactérias, processos de mineralização inorgânica, de abrasão ou erosão, e neomorfismo. $\mathrm{Na}$ área pesquisada, microfitólitos são os principais componentes de dolarenitos que ocorrem associados a estromatólitos. Entre os microfitólitos, observa-se freqüentemente bioclastos semelhantes a Vesiculartes Reitlinger (1959 apud Bertrand- Sarfati 1972), um tipo de Catagraph. Na descrição de Bertrand-Sarfati (1972), Vesicularites são grãos constituídos por pequenas vesículas subesféricas, ovais ou irregulares, que podem formar agregados (Prancha 4, foto 6; Prancha 5, fotos 2 e 3). 


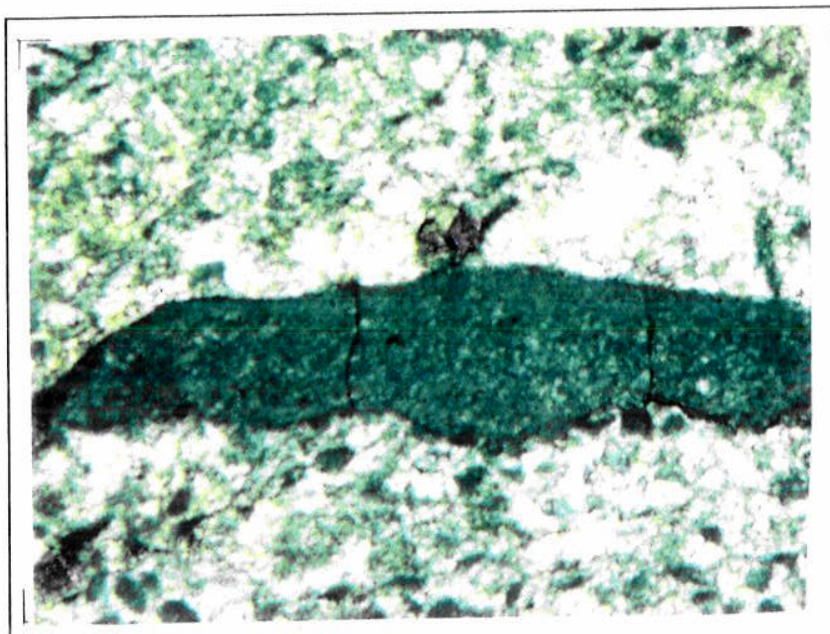

Foto 1 - Fotomicrografia de bioclasto de calcário microbiano críptico. X.N. 15x

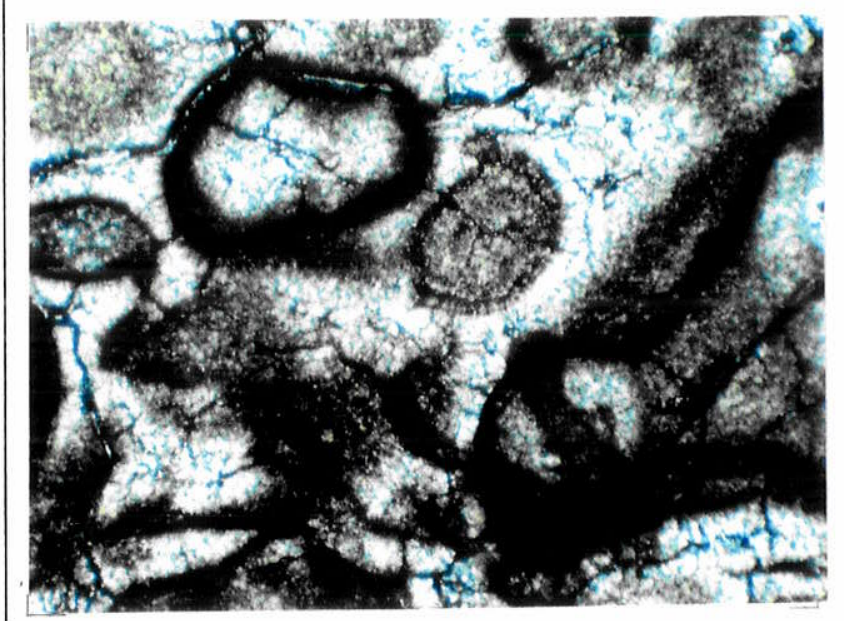

Foto 3 - Fotomicrografia de microfitólitos dolomitizados, onde se observa vestígios de franja isópaca acicular. X.N. 70x

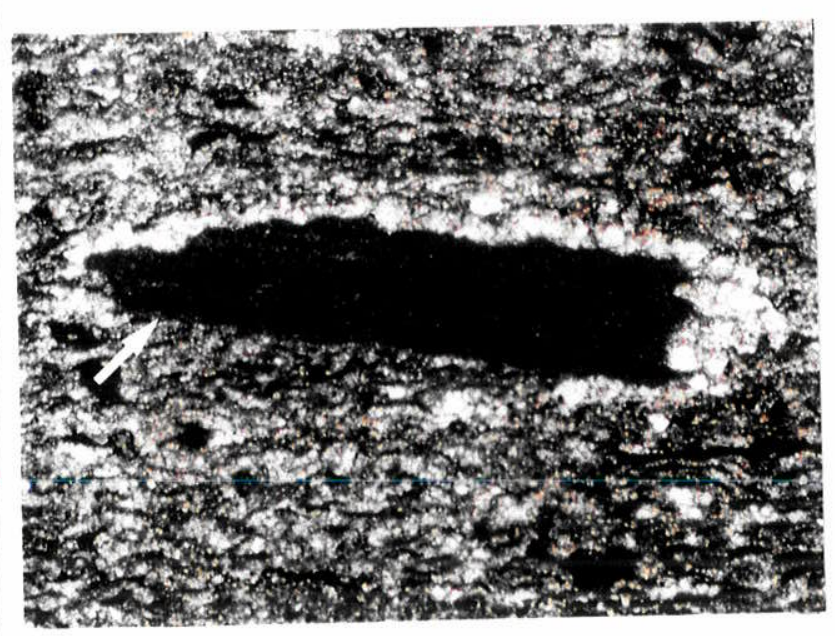

Foto 5 - Fotomicrografia de bioclasto microbiano semelhantes a algal chips (seta). L.N. 10x

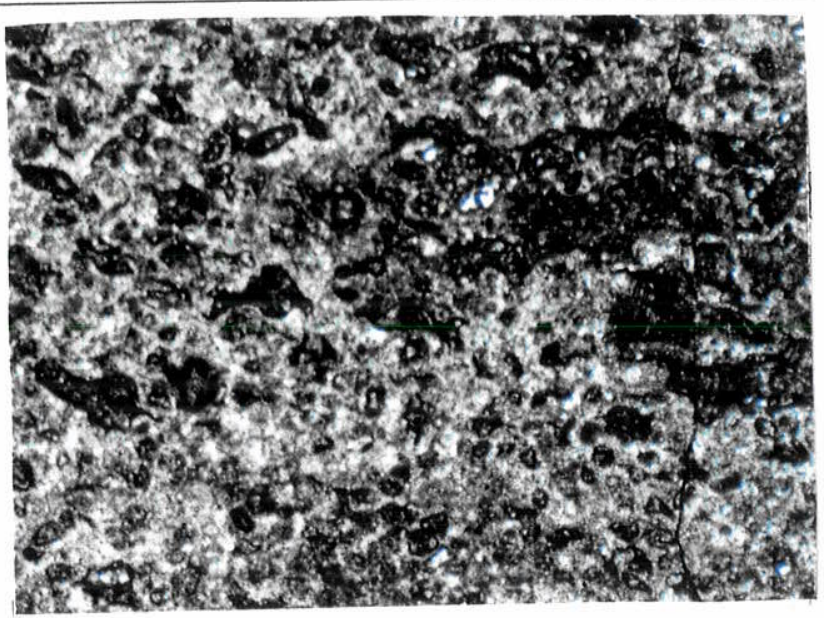

Foto 2 - Fotomicrografia de microfitólitos. L.N. 10x

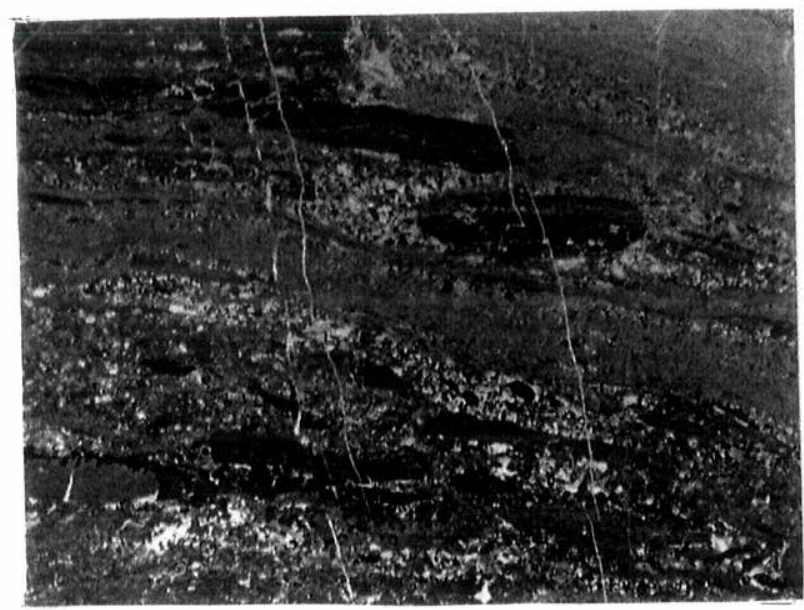

Foto 4 - Fotomicrografia de bioclastos estromatolíti cos. L.N. $4 x$

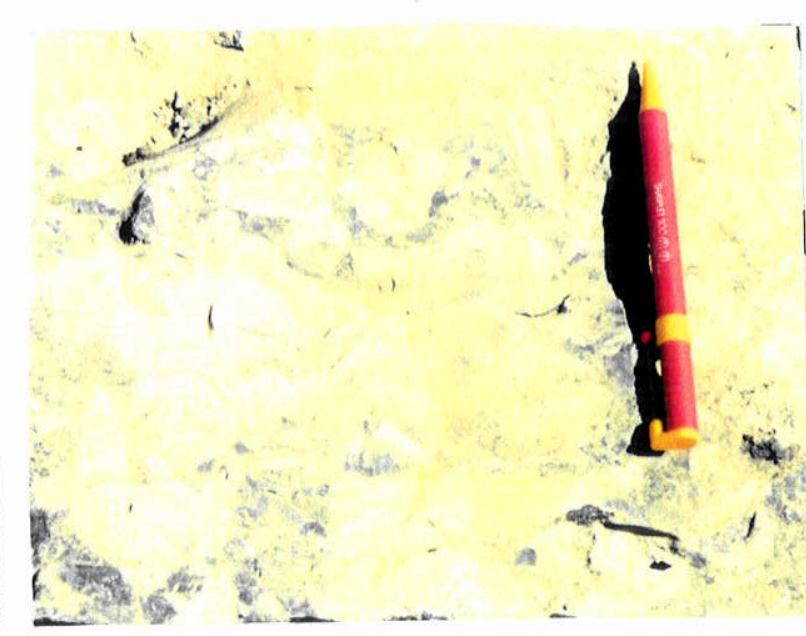

Foto 6 - Fotomicrografia de bioclastos de estromatólitos que ocorrem associados a estromatólito ramificado. 
Em lingua portuguesa, o termo fitólito é utilizado para cristais minerais, por exemplo opala, segregados por algumas plantas, e não tem nenhuma implicação com o termo microfitólito como utilizado nesta pesquisa.

\section{2 - LAMA CARBONÁTICA}

A lama carbonática é um dos constituintes mais comuns das rochas carbonáticas. Freqüentemente, o termo é utilizado como sinônimo de micrita, mas micrita (contração de microcrystalline calcite) refere-se apenas a carbonato de granulação argila, composto por cristais com dimensöes entre $1 \mu \mathrm{m}$ e $4 \mu \mathrm{m}$. Considera-se que micrita pode se formar de diferentes maneiras, tais como por rápida precipitação química ou bioquímica no fundo oceânico, por segregação diagenética ou pode resultar da abrasão de carbonatos preexistentes (Folk 1962).

O termo micrita é utilizado de várias formas. Pode designar a matriz microcristalina de uma rocha, isto é, um componente; pode ser utilizado como um termo de combinação na classificação das rochas carbonáticas, por exemplo, pelmicrito (Folk op. cit.); pode também designar uma rocha constituída inteiramente por calcita microcristalina, quando é sinônimo de lama carbonática, de calcilutito ou de calcário afanítico.

Rochas compostas por cristais maiores que $5 \mu \mathrm{m}$ não devem ser denominadas micríticas; quando os cristais têm dimensöes situadas entre $5 \mu \mathrm{m}$ e $15 \mu \mathrm{m}$, utiliza-se o termo microespato (Folk 1959).

Para fins sedimentológicos, o termo lama, como usado atualmente para sedimentos modernos, abrange componentes com dimensöes de até $62 \mu \mathrm{m}$. Neste trabalho o termo calcilutito foi utilizado para essa faixa de granulometria. Quando foi possivel identificar carbonatos detríticos de granulometria silte, os mesmos foram denominados calcissiltitos; em caso de dúvida, quando poderiam ser reflexo de processos neomórficos, foram classificados como calcilutitos (Prancha 3, foto 6).

\section{3 - BIOCONSTRUÇÕES}

$\mathrm{Na}$ área pesquisada, as bioconstruçöes são estromatolíticas ou crípticas (Riding 1991).

Para a descrição dos estromatólitos foram utilizados os conceitos e a classificação contida no Handbook of Stromatolites (Grey et al. 1992, 4th. draft ), o qual é baseado em grande parte no trabalho desenvolvido por Hofmann (1969). 
Estromatólitos são estruturas organossedimentares laminadas, produzidas por trapeamento, aglutinação de sedimentos e/ou precipitação mineral, resultantes do crescimento e atividade metabólica de microorganismos (Awramick \& Margulis 1974).

$\mathrm{Na}$ área estudada predominam estromatólitos estratiformes, mas ocorrem também elementos colunares e dômicos.

Carbonatos microbianos cripticos (Riding 1991) constituem bioconstruçōes que não apresentam feições macroscópicas distintivas, mas que possuem microfábrica compativel com as apresentadas por construçōes microbianas; pode ser classificado ainda como rocha sedimentar criptalgal (Aitken 1967), microbialito (Burne \& Moore 1987) ou microbolito (Riding op. cit.), mas essas denominações são gerais e abrangem vários tipos de construções microbianas, entre elas estromatólitos, trombólitos e calcários microbianos crípticos, entre outras.

Tanto os estromatólitos quanto as bioconstruçöes cripticas são derivados da interação de microorganismos bentônicos, cocoidais ou filamentosos, possivelmente cianobactéria, com o meio ambiente onde se desenvolveram.

As bioconstruçỏes podem constituir biohermas ou biostromas. Biohermas são estruturas organossedimentares circunscritas, freqüentemente de aspecto lenticular. Biostromas são predominantemente estratiformes, e constituem bancos extensos, cuja maior dimensão é sempre muito maior que a espessura.

\section{4 - CLASSIFICAÇÕES ADOTADAS PARA AS ROCHAS CARBONÁTICAS DETRITICAS}

Os carbonatos detríticos foram classificados segundo Folk (1959, 1962), Dunham (1962) e Embry \& Klovan (1971).

\subsection{1- Classificação de Folk $(1959,1962)$}

É uma classificação litológica, baseada essencialmente nos componentes da rocha carbonática, isto é grãos aloquímicos, matriz e cimento. Identifica quatro grupos básicos, a saber: carbonatos onde os grãos aloquímicos estão cimentados por calcita espática, carbonatos com os grãos aloquímicos em matriz micrítica, carbonatos microcristalinos sem aloquímicos e estruturas orgânicas desenvolvidas in situ, denominados biolititos. Os dois primeiros grupos constituem as rochas aloquimicas, no terceiro estão incluidas as rochas ortoquímicas; os biolititos abrangem construçōes recifais e outros tipos de bioconstruções 
autóctones. Os grãos aloquímicos podem ser intraclastos, oólitos, fósseis ou pelóides (Figura 5).

É uma classificação consagrada e foi utilizada sistematicamente neste trabalho, em conjunto com a classificação de Dunham.

\subsection{2 - Classificação de Dunham (1962)}

É baseada essencialmente na textura deposicional da rocha carbonática, e segundo o autor, três feições são especialmente úteis para classificar carbonatos que preservam sua textura deposicional (Figura 6).

1- A presença ou ausência de lama carbonática, o que permite diferenciar carbonatos lamosos, de grainstones, que não apresentam lama.

2- A abundância de grãos, que permite subdividir os carbonatos lamosos em mudstones (menos de $10 \%$ de grãos), wackestone (mais de $10 \%$ de grãos) e packstones, que embora contenham lama na matriz, säo sustentados pelos clastos como os grainstones. Wackestones são rochas sustentadas pela matriz.

3- A evidência de trapeamento de sedimentos durante a deposição do carbonato caracteriza o boundstone.

Rochas carbonáticas que praticamente não preservam feições deposicionais são consideradas à parte, e denominadas carbonatos cristalinos

A classificação de Dunham é extremamente prática e fornece indicações sobre a energia do meio ambiente onde se formaram as rochas carbonáticas. Sua utilização apresenta algumas limitaçōes, especialmente em se tratando de carbonatos precambrianos, onde o neomorfismo freqüentemente mascara muitas feições primárias, deposicionais. É o caso da dificuldade que pode ocorrer, às vezes, quando se tenta diferenciar packstone, de grainstone; o mesmo acontecer diferenciação entre espato e pseudoespato.

Esta classificação foi freqüentemente utilizada nesta pesquisa, com as devidas ressalvas. Os termos foram mantidos como no original em ingles, pela dificuldade de tradução e por serem de uso consagrado.

\subsection{3 - Classificação de Embry \& Klovan (1971)}

Utiliza basicamente a classificação de Dunham (1962), com modificações e acréscimos, em especial no que se refere a calcirruditos e a bioconstruçöes (Figura 6). Os 

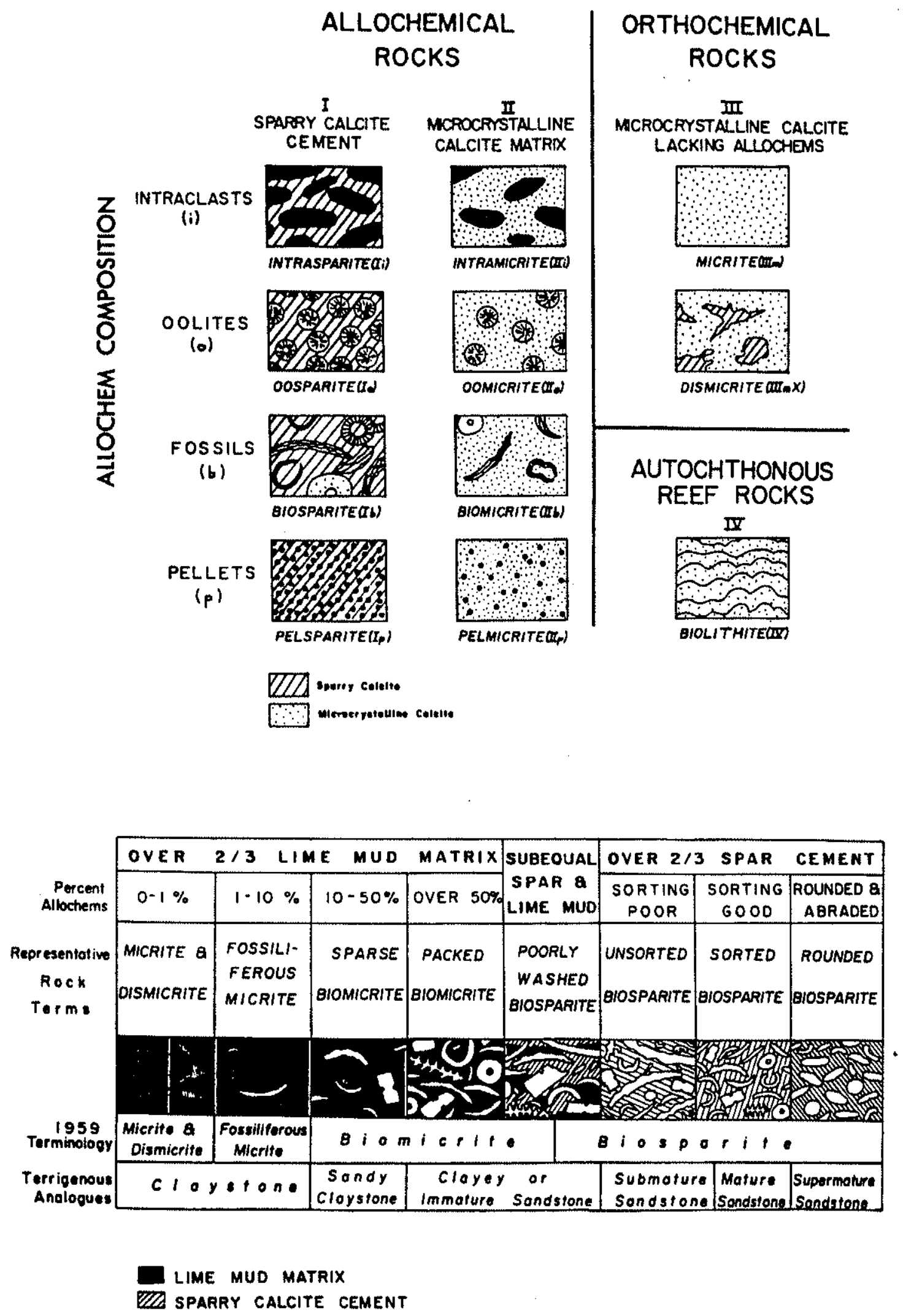

Figura 5 - Classificação de Folk (1962) para rochas carbonáticas e texturas de carbonatos. 


\begin{tabular}{|c|c|c|c|c|c|}
\hline \multicolumn{5}{|c|}{ Depositional Texture recongnizatile } & \multirow{3}{*}{$\begin{array}{l}\text { 1) pepositional texture } \\
\text { not recognizithic } \\
\text { Crystalline carbonate }\end{array}$} \\
\hline \multicolumn{4}{|c|}{$\begin{array}{l}\text { ()riginal conmonents not bound together } \\
\text { during depenitions }\end{array}$} & \multirow{5}{*}{$\begin{array}{c}\text { Original components } \\
\text { were bound together } \\
\text { during deposition... as } \\
\text { shown by intergrown } \\
\text { sheletal matter. lami- } \\
\text { nation contrary to } \\
\text { gravity. or sediment- } \\
\text { foored cavities that } \\
\text { arc roofed over by } \\
\text { organic or question- } \\
\text { ably organic matter } \\
\text { and are too large to } \\
\text { be interstices. }\end{array}$} & \\
\hline \multicolumn{3}{|c|}{$\begin{array}{l}\text { Contains mud } \\
\text { (particles of claly and fine silt size) }\end{array}$} & \multirow{3}{*}{$\begin{array}{l}\text { Lacks mud } \\
\text { and is grain- } \\
\text { supported }\end{array}$} & & \\
\hline \multicolumn{2}{|c|}{ Mud-supported } & \multirow{2}{*}{$\begin{array}{l}\text { Gratin- } \\
\text { supported }\end{array}$} & & & \\
\hline $\begin{array}{l}\text { Less than } \\
10 \% \text { grains }\end{array}$ & $\begin{array}{l}\text { More thatn } \\
10^{\circ} \% \text { grains }\end{array}$ & & & & \multirow[t]{2}{*}{$\begin{array}{l}\text { (Subdivide according } \\
\text { to classifications } \\
\text { designed to bear on } \\
\text { physical texture or } \\
\text { diagenesis.) }\end{array}$} \\
\hline Mudstone & Wackstone & Packstone & Grainstone & & \\
\hline
\end{tabular}

\section{Classificação de Dunham (1962)}

\begin{tabular}{|c|c|c|c|c|c|c|c|c|}
\hline \multicolumn{6}{|c|}{$\begin{array}{l}\text { Allochthonous limestones } \\
\text { original components not organically } \\
\text { bound during deposition }\end{array}$} & \multicolumn{3}{|c|}{$\begin{array}{l}\text { Autochthonous limestones } \\
\text { original components organi- } \\
\text { cally bound during deposition }\end{array}$} \\
\hline \multicolumn{4}{|c|}{ Less than $10 \%>2 \mathrm{~mm}$ components } & \multicolumn{2}{|c|}{$\begin{array}{l}\text { Greater than } \\
10 \%>2 \mathrm{~mm} \\
\text { components }\end{array}$} & \multirow{4}{*}{$\begin{array}{l}\text { By } \\
\text { organ- } \\
\text { isms } \\
\text { which } \\
\text { act } \\
\text { as } \\
\text { batmes }\end{array}$} & \multirow{4}{*}{$\begin{array}{l}\text { By } \\
\text { organ- } \\
\text { isms } \\
\text { which } \\
\text { encrust } \\
\text { and } \\
\text { bind }\end{array}$} & \multirow{4}{*}{$\begin{array}{l}\text { By } \\
\text { organ- } \\
\text { isms } \\
\text { which } \\
\text { build } \\
\text { a rigid } \\
\text { frame- } \\
\text { work }\end{array}$} \\
\hline Cont & $\begin{array}{l}\text { ains lime } \\
<.0 .3 \mathrm{mn}\end{array}$ & & $\begin{array}{l}\text { No } \\
\text { lime } \\
\text { mud }\end{array}$ & \multirow{3}{*}{$\begin{array}{l}\text { Matrix } \\
\text { sup- } \\
\text { ported }\end{array}$} & \multirow{3}{*}{$\begin{array}{l}>2 \mathrm{~mm} \\
\text { com- } \\
\text { ponent } \\
\text { sup- } \\
\text { ported }\end{array}$} & & & \\
\hline \multicolumn{2}{|c|}{ Mud supported } & \multirow{2}{*}{\multicolumn{2}{|c|}{$\begin{array}{c}\text { Grain } \\
\text { supported }\end{array}$}} & & & & & \\
\hline $\begin{array}{c}\text { Less than } \\
10 \% \\
\text { grains } \\
\{>0.9 \mathrm{~mm} \\
<2 \mathrm{~mm} \mid\end{array}$ & $\begin{array}{l}\text { Greater } \\
\text { than } \\
10 \% \\
\text { grains }\end{array}$ & & & & & & & \\
\hline $\begin{array}{l}\text { Mud- } \\
\text { stone }\end{array}$ & $\begin{array}{l}\text { Wacke- } \\
\text { stone }\end{array}$ & $\begin{array}{l}\text { Pack- } \\
\text { stone }\end{array}$ & $\begin{array}{l}\text { Grain- } \\
\text { stone }\end{array}$ & $\begin{array}{l}\text { Float- } \\
\text { stone }\end{array}$ & $\begin{array}{l}\text { Rud. } \\
\text { stone }\end{array}$ & $\begin{array}{l}\text { Baffle- } \\
\text { stone }\end{array}$ & $\begin{array}{l}\text { Bind. } \\
\text { stone }\end{array}$ & $\begin{array}{l}\text { Frame- } \\
\text { stone }\end{array}$ \\
\hline
\end{tabular}

Classificação de Embry \& Klovan (1971)

Figura 6 - Classificações de Dunham (1962) e Embry \& Klovan (1971) para rochas carbonáticas. 
calcirruditos possuem mais de $2 \%$ dos seus componentes com dimensöes maiores que dois milimetros, e podem ser sustentados pela matriz, floatstones, ou ser sustentados pelos clastos, quando são denominados rudstones. As denominações adotadas para os calcirruditos foram mantidas em inglês. As subdivisões adotadas para carbonatos bioconstruídos, bafflestone, bindstone e framestone, não foram utilizadas neste trabalho. 


\section{5 - DESCRIÇÃO DAS FÁCIES}

Foram definidas 23 fácies carbonáticas principais no Grupo Bambui (tabelas 1 e 2). A partir da reconstrução dos conjuntos de fácies e de sua sucessão vertical, foi possível identificar 4 intervalos principais, que correspondem a ciclos de sedimentação bem definidos (Figuras 7,8 e 9).

As fácies carbonáticas definidas no Grupo Bambui foram codificadas de forma a indicar a sua constituição.

Os códigos utilizados foram os seguintes:

C - calcário; Ca - calcarenito; $\mathrm{Cl}$ - calcilutito; $\mathrm{Cr}$ - calcirrudito; cc - calcítico

MRG - marga; D - dolomito/dolomítico; E - estromatólito/estromatolítico

d-dômicos; c - colunares; p - pseudocolunares; es - estratiformes

$c p$ - colunares a pseudocolunares; $m$ - microbiano críptico

it - intraclástico; od - ooidal; 00 - oolítico

I - laminado/ laminação; a - estratificação cruzada acanalada;

z -estratificação cruzada; $\mathbf{g}$ - gradação normal; f - floatstone

n - neomorfizado/ neomorfismo; s - silicificado

b - brecha de dissolução/colapso

\section{1 - FÁCIES Cm: Calcário microbiano criptico}

Esta fácies ocorre em toda a área pesquisada e tem cerca de 15 metros de espessura aflorante. Apresenta intercalaçōes muito subordinadas de calcarenitos e calcirruditos.

Macroscopicamente, trata-se de um calcário cinza escuro a preto, que tem como principal caracteristica o aspecto rítmico. A ritmicidade é dada pela alternância de níveis maciços, centimétricos a decimétricos, não deformados e de níveis decimétricos, compostos por lâminas milimétricas a estratos centimétricos, fortemente afetadas por compactação (Prancha 6, foto 1).

Os estratos são suborizontais, planares e de grande continuidade lateral, podendo ser acompanhados por dezenas de metros. Os leitos que compõem os niveis compactados apresentam adelgaçamentos freqüentes, são limitados por suturas estilolíticas ou dissolution seams e localmente podem ter aspecto brechóide.

Embora o calcário seja argiloso, não se observou níveis argilosos ou margosos individualizados. Possui, no entanto, entre os estratos, filmes constituidos por material 
Tabela 1

DESCRIÇÃO DAS FÁCIES DE

CARBONATOS DETRITICOS

\begin{tabular}{|c|c|c|c|c|c|}
\hline FÁCIES & LITOLOGIA & TEXTURA & FEIÇŌES DIAGENÉTICAS & $\begin{array}{l}\text { ESTRUTURAS } \\
\text { SEDIMENTARES }\end{array}$ & $\begin{array}{c}\text { AMBIENTE } \\
\text { DEPOSICIONAL }\end{array}$ \\
\hline Cs & Calcissiltitos & & $\begin{array}{l}\text { Dissolução de grâos; cavidades preenchidas por } \\
\text { calcita espática; neormorfismo }\end{array}$ & $\begin{array}{l}\text { Laminaçāo plano-paralela a ondulada e cruzada. } \\
\text { Gradaçă nomnal }\end{array}$ & sampa externa \\
\hline Cr & Calcirruditos & Sustentado pelos clastos & Dolomitzaçắo parcial da matriz em alguns niveis & $\begin{array}{l}\text { Calcirruditos năo organizados - maciços; raros com } \\
\text { gradaçăo normal }\end{array}$ & rampa externa \\
\hline Crg & $\begin{array}{l}\text { Calciruditos / calcarenitos I } \\
\text { calcissititios }\end{array}$ & $\begin{array}{l}\text { Calcirruditos sustentados } \\
\text { pelos clastos }\end{array}$ & Dolomitização parcial da matriz em alguns niveis & $\begin{array}{l}\text { Gradaçäo nornal incipiente. Laminação cruzada nos } \\
\text { calcissititios }\end{array}$ & rampa externa \\
\hline CaCrd & $\begin{array}{l}\text { Caicarentitos / calcissiltitos I } \\
\text { calcirruditos }\end{array}$ & $\begin{array}{l}\text { Calciruditos sustentados } \\
\text { pelos clastos }\end{array}$ & Parcialmente dolomitizados & $\begin{array}{l}\text { Laminaçāo plano-parabiala, cruzzada por ondas, marcas } \\
\text { onduladas. Gradaçăo normai }\end{array}$ & rampa externa \\
\hline Crf & Caicirruditos & $\begin{array}{l}\text { Calcirruditos sustentados } \\
\text { pela matriz }\end{array}$ & & $\begin{array}{l}\text { Leitos nudáceos com limites difusos. Gradação normal e } \\
\text { marcas onduladas sâo raras }\end{array}$ & zampa externa \\
\hline $\mathrm{CaDz}$ & Caicarenitos & & $\begin{array}{l}\text { Cimenta̧̧ão precoce, dołornitizaçãa, dissoluçäa } \\
\text { parcial, neornorfismo }\end{array}$ & $\begin{array}{l}\text { Estratificaçâo cruzada planar de médio porte. Marcas } \\
\text { onduladas }\end{array}$ & rampa interna \\
\hline CaDa & Calcarenitos & & & $\begin{array}{l}\text { Estratificação cruzada por ondas; estratificaçāo } \\
\text { acanalada de pequeno porte }\end{array}$ & rampa interna \\
\hline Dcc & Dofomito calcitico & Cristalina & Dolomitizzaçâo. Dissolução & $\begin{array}{l}\text { Vestigios de estratificaçāo cruzada, niveis granulares e } \\
\text { estromatoblitos }\end{array}$ & $\begin{array}{l}\text { rampa interna } \\
\text { Laguna de plataforma \& ambiente perilitoràneo }\end{array}$ \\
\hline DEdc & Dofarenito coidal & & Dolomitizaçăo, dissoluçâo, silicificação & & Ambiente perilitoráneo de alta energia \\
\hline DI & $\begin{array}{l}\text { Dolomito com laminaçōes } \\
\text { isregulares }\end{array}$ & & Dolomitização & & Exposição subaérea \\
\hline \multirow{3}{*}{ 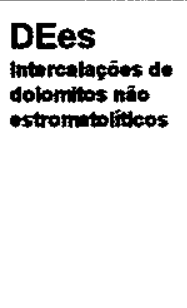 } & $\begin{array}{l}\text { Dolarentito constituido por } \\
\text { microfitolitos }\end{array}$ & & $\begin{array}{l}\text { Franja isópaca acicular aragonitica, dolomitizada de } \\
\text { forma mimica. Doformitizaçăo precoce }\end{array}$ & Estratificaçăo cruzada por ondas. Marcas onduladas & $\begin{array}{l}\text { Ambiente de águas rasas e levernente } \\
\text { agitadas em inframare }\end{array}$ \\
\hline & $\begin{array}{l}\text { Dolarenito composto por } \\
\text { microfitólitos }\end{array}$ & & Dolomitizaçāo & Estratificaçāo cruzada por ondas. Marcas onduladas & Inframare \\
\hline & $\begin{array}{l}\text { Dolarenito com bioclastos. } \\
\text { óides, agregados e } \\
\text { intraclastos }\end{array}$ & & $\begin{array}{l}\text { Franja isópaca acicular aragonitica, dolomitizada de } \\
\text { forma mimica }\end{array}$ & & Depósito de termpestade ern àguas rasas \\
\hline
\end{tabular}


Tabela 1 (continuação)

DESCRIÇÃO DAS FÁCIES DE

CARBONATOS DETRITICOS

\begin{tabular}{|c|c|c|c|c|c|}
\hline FÁCIES & LITOLOGIA & TEXTURA & FEIÇÕES DIAGENÉTICAS & ESTRUTURAS SEDIMENTARES & $\begin{array}{l}\text { AMBIENTE } \\
\text { DEPOSICIONAL }\end{array}$ \\
\hline DEes & Doloruditio & $\begin{array}{l}\text { Sustentada pelos clastos } \\
\text { lamelares }\end{array}$ & & Gradaçāo normal & Ambiente perilitoráneo de àguas rasas \\
\hline Caoo & Calcarenitos ooliticos & & Neomortismo, dissoluçāa, silicificcaçāo & Estratificaçắo cruzada por ondas; marcas onduladas & Depósitos de Middle Shelf \\
\hline $\mathrm{CaCl}$ & $\begin{array}{l}\text { Calcarenitos e } \\
\text { calcilutitos }\end{array}$ & & Neomortismo. Nöduios de silex & $\begin{array}{l}\text { Laminaç̄os cruzadas por ondas; acamamento flasere } \\
\text { wavy }\end{array}$ & Depositos de middle shelf \\
\hline CII & Calcilututios & & Pirita disseminada & Laminaçâo plano-paralela & $\begin{array}{l}\text { Depósitios de planicie de maré restrita - } \\
\text { inframaré }\end{array}$ \\
\hline Csi & Calcissititios & & Neomorfismo; cristais de anidrita & Laminaậ̆es cruzadas por ondas; gretas de contraçăo & Depósitos de planicie de mare restrita \\
\hline MRG & Margas & & Neomorfismo & $\begin{array}{l}\text { Laminaçbes cruzadas por ondas, drapes, acamamento } \\
\text { lenticular, laminasąăo plano-paraletla a ondulada }\end{array}$ & Depósito de planicie de mare restrita \\
\hline
\end{tabular}


Tabela 2

\section{DESCRIÇÃO DAS FÁCIES DE} BIOCONSTRUÇŌES

\begin{tabular}{|c|c|c|c|c|c|}
\hline FÁCIES & LITOLOGIA & MORFOLOGIA & $\begin{array}{c}\text { ESTRUTURA } \\
\text { ORGANOSSE } \\
\text { DIMENTAR }\end{array}$ & FEIÇŌES MICROSCÓPICAS / DIAGENÉTICAS & $\begin{array}{l}\text { AMBIENTE } \\
\text { DEPOSICIONAL }\end{array}$ \\
\hline $\mathbf{C m}$ & $\begin{array}{l}\text { Calcário argiloso, } \\
\text { micrítico, de microfábrica } \\
\text { peloidal a grumosa }\end{array}$ & $\begin{array}{l}\text { Calćario microbiano criptico, sem estruturas } \\
\text { macroscópicas }\end{array}$ & Biostroma & 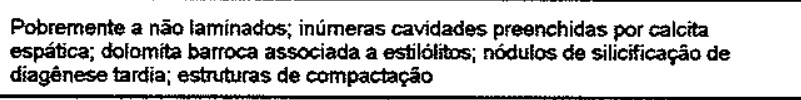 & $\begin{array}{l}\text { Rampa externa, abaixo do nivel de } \\
\text { açăo de ondas normais }\end{array}$ \\
\hline DEcp & Dolomito estromatolitico & $\begin{array}{l}\text { Estromatolitos colunares de pequeno porte, } \\
\text { associados a estromatolitos estratifomes }\end{array}$ & Biohermas & $\begin{array}{l}\text { Niveis lamosos e granulares; cavidades abertas por dissoluçäo forradas por franja } \\
\text { isopaca neomorfisada e contendo calcita espática; cristais aciculares de anidrita }\end{array}$ & Ambiente lagunar \\
\hline DEd & Dolomito estromatolitico & $\begin{array}{l}\text { Estromatólitos dómicos de pequeno porte e } \\
\text { relevo alto }\end{array}$ & Bioherma & $\begin{array}{l}\text { Laminaçăo fenestral; dissoluçâơcimentaçāo por calcita espática; duas geraçōes } \\
\text { de dolomita }\end{array}$ & Ambiente perilitorảneo \\
\hline DEdc & Dolotnito estromatolitico & $\begin{array}{l}\text { Estromatólitos dômicos e colunares de } \\
\text { grande porte e relevo alto, associados a } \\
\text { dolarenito ooidal }\end{array}$ & Biohermas & Oconem associados a dolarenito ooidal & Ambiente perilitoräneo \\
\hline DEb & Dolomito estromatolitico & Estromatolitos estratiformes & Biostroma & Brechas de dissoluçăa no topo do biostroma & Ambiente perilitoráneo \\
\hline \multirow{4}{*}{ DEes } & Dolomito estromatolitico & $\begin{array}{l}\text { Estromatólitios em macicos aboorescentes, } \\
\text { colunares a pseudocolunares }\end{array}$ & Bioherma & $\begin{array}{l}\text { Ausência de larninaçáo fenestral, de material lamoso ou de evidências de } \\
\text { ressecaçāo; material granular enté as colunas enas laminaçoes }\end{array}$ & $\begin{array}{l}\text { Planície de maré } \\
\text { Inframaré a intermaré }\end{array}$ \\
\hline & Dolomito estromatolitico & $\begin{array}{l}\text { Estromatólitos estratiformes com pequenas } \\
\text { colunas esparsas }\end{array}$ & Biostroma & 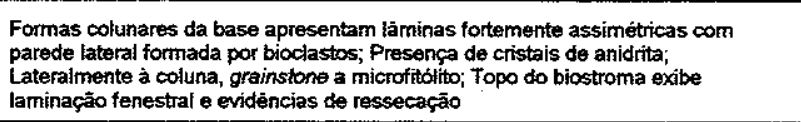 & $\begin{array}{l}\text { Planície de maré } \\
\text { Inframaré a internaré }\end{array}$ \\
\hline & Dolomito estromatolitico & $\begin{array}{l}\text { Estromatóltos estratiformes a pseudo } \\
\text { colunares com formas dômicas e colutuares } \\
\text { esparsas }\end{array}$ & Biostroma & $\begin{array}{l}\text { Aportes irregulares de grāos, que ficam presos nas laminaç̄oses estromatoliticas; } \\
\text { Laminaçăo fenestral e e feiçoes de diagēnese vadosa }\end{array}$ & $\begin{array}{l}\text { Planicie de maré } \\
\text { Inframaré a intermaré }\end{array}$ \\
\hline & Dolomito estromatolitico & $\begin{array}{l}\text { Estromatölitos estratiformes com intercalaçāo } \\
\text { de dolarentito contendo bioclastos de } \\
\text { estromatólitos imbricados }\end{array}$ & Biostroma & $\begin{array}{l}\text { Laminaçăo fenestral; niveis granulares contendo um pouco de tama; franja isópaca } \\
\text { acicular ao redor dos aloquimicos }\end{array}$ & $\begin{array}{l}\text { Planicie de maré } \\
\text { Inframaré a intermaré }\end{array}$ \\
\hline
\end{tabular}


Tabela 2 (continuação)

\section{DESCRIÇÃO DAS FÁCIES DE}

BIOCONSTRUÇŌES

\begin{tabular}{|c|c|c|c|c|c|}
\hline FÁCIES & LITOLOGIA & MORFOLOGIA & $\begin{array}{c}\text { ESTRUTURA } \\
\text { ORGANOSSE } \\
\text { DIMENTAR }\end{array}$ & FEIÇŌES MICROSCÓPICAS / DIAGENÉTICAS & $\begin{array}{l}\text { AMBIENTE } \\
\text { DEPOSICIONAL }\end{array}$ \\
\hline \multirow[t]{2}{*}{ DEes } & Dolomito estromatolitico & $\begin{array}{l}\text { Estromatbilitos estratiformes a } \\
\text { pseudicocolunares }\end{array}$ & Biostroma & 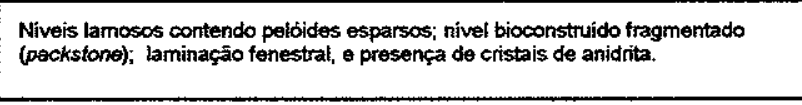 & $\begin{array}{l}\text { Planicie de maré } \\
\text { Inframaré a internaré }\end{array}$ \\
\hline & Dolomito estromatolitico & 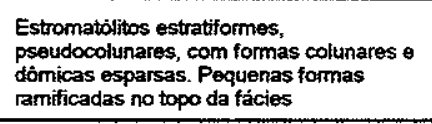 & Biostroma & $\begin{array}{l}\text { Na base, espossso pacote granular seguido por estromatóititos estratiformes com } \\
\text { nodulusos de silex }\end{array}$ & Planicie de maré \\
\hline CE & Calcário estromatolitico & $\begin{array}{l}\text { Pseudocolunares com formas colunares e } \\
\text { dômicas associadas trequenternente }\end{array}$ & $\begin{array}{l}\text { Biohemass semelhantes } \\
\text { a patch roefs }\end{array}$ & 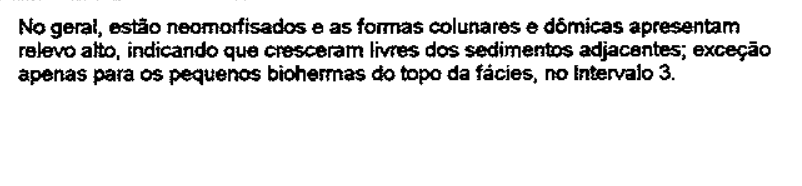 & 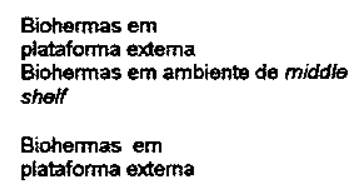 \\
\hline
\end{tabular}




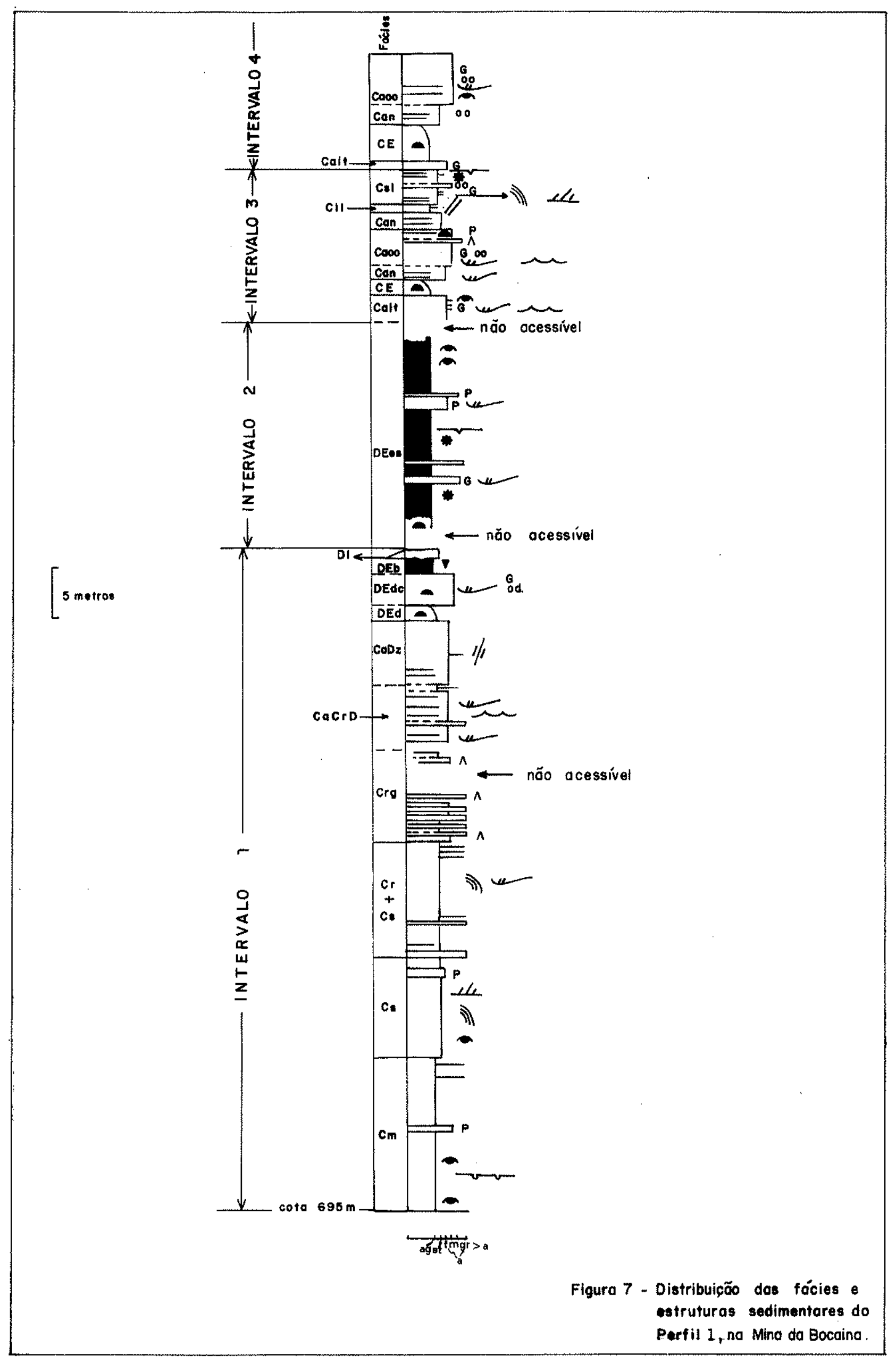




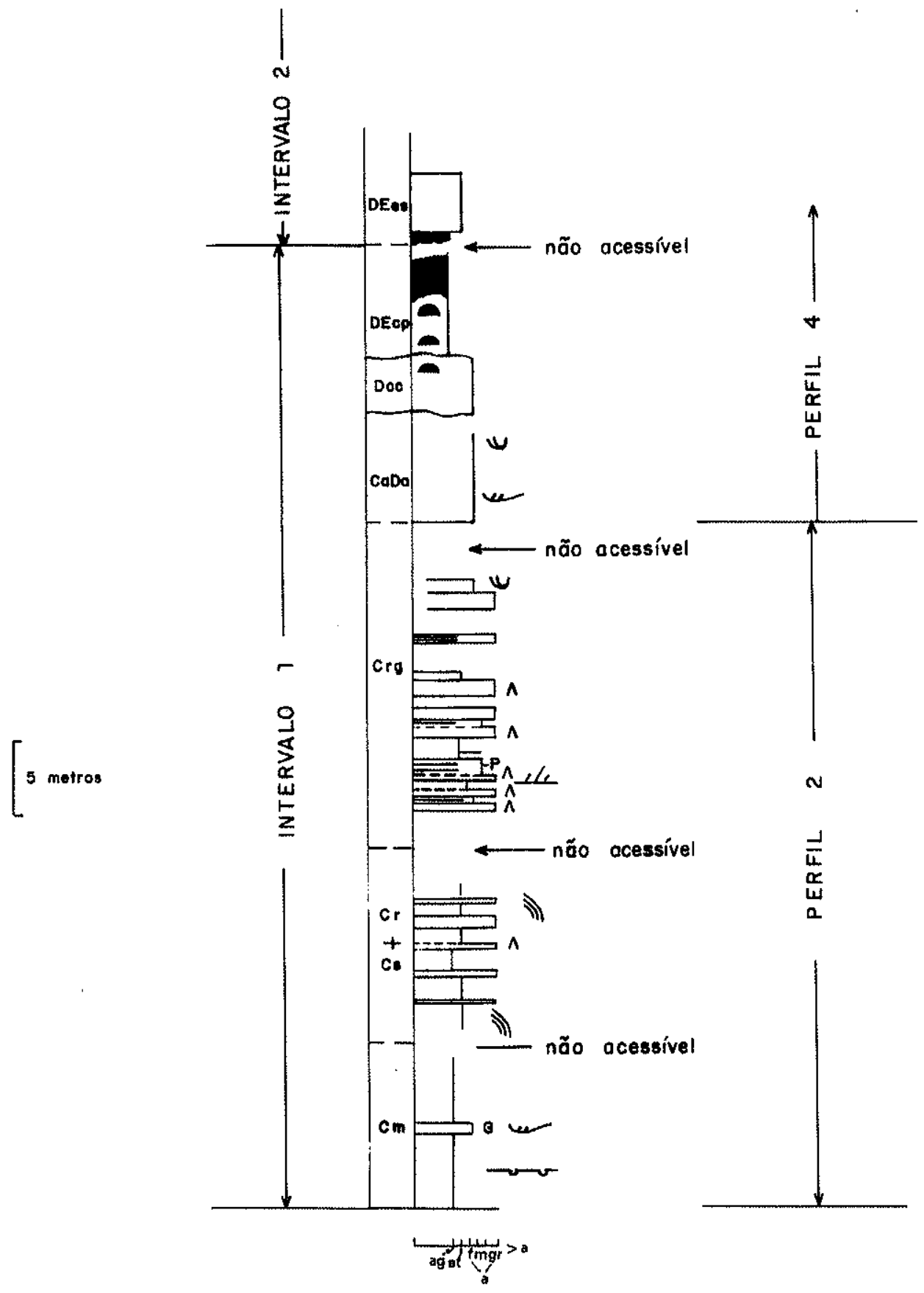

Figura 8 - Distribuicão das fócies e estruturas sedimentares no perfil composto petos pertis 2 (entrada da COMIG) e 4 (mina em atividade da COMIG). 


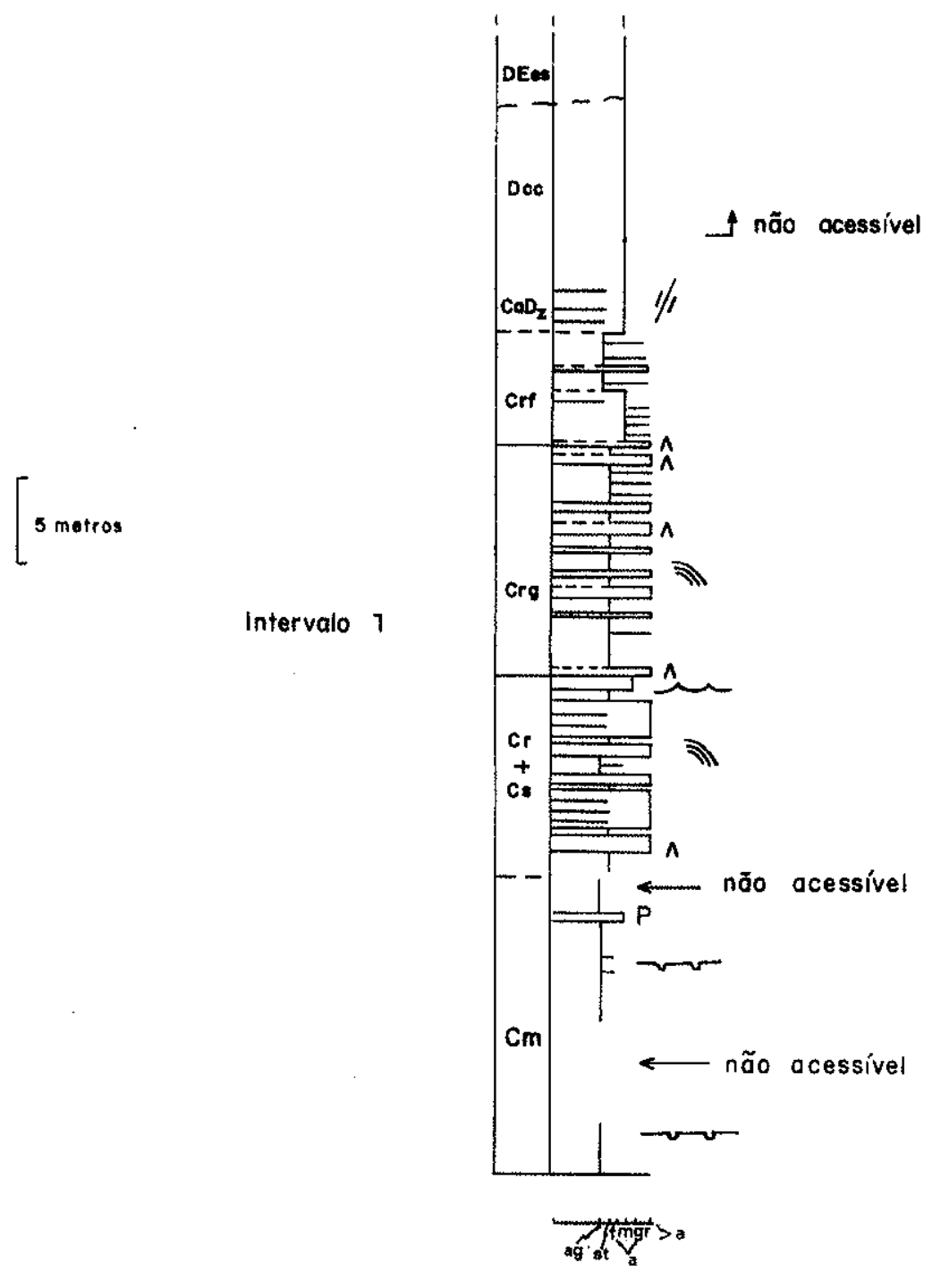

Figura 9 - Distribuicão das fócies e estruturas sedimentares do Perfil 3, na mino abandonada da COMIG. 


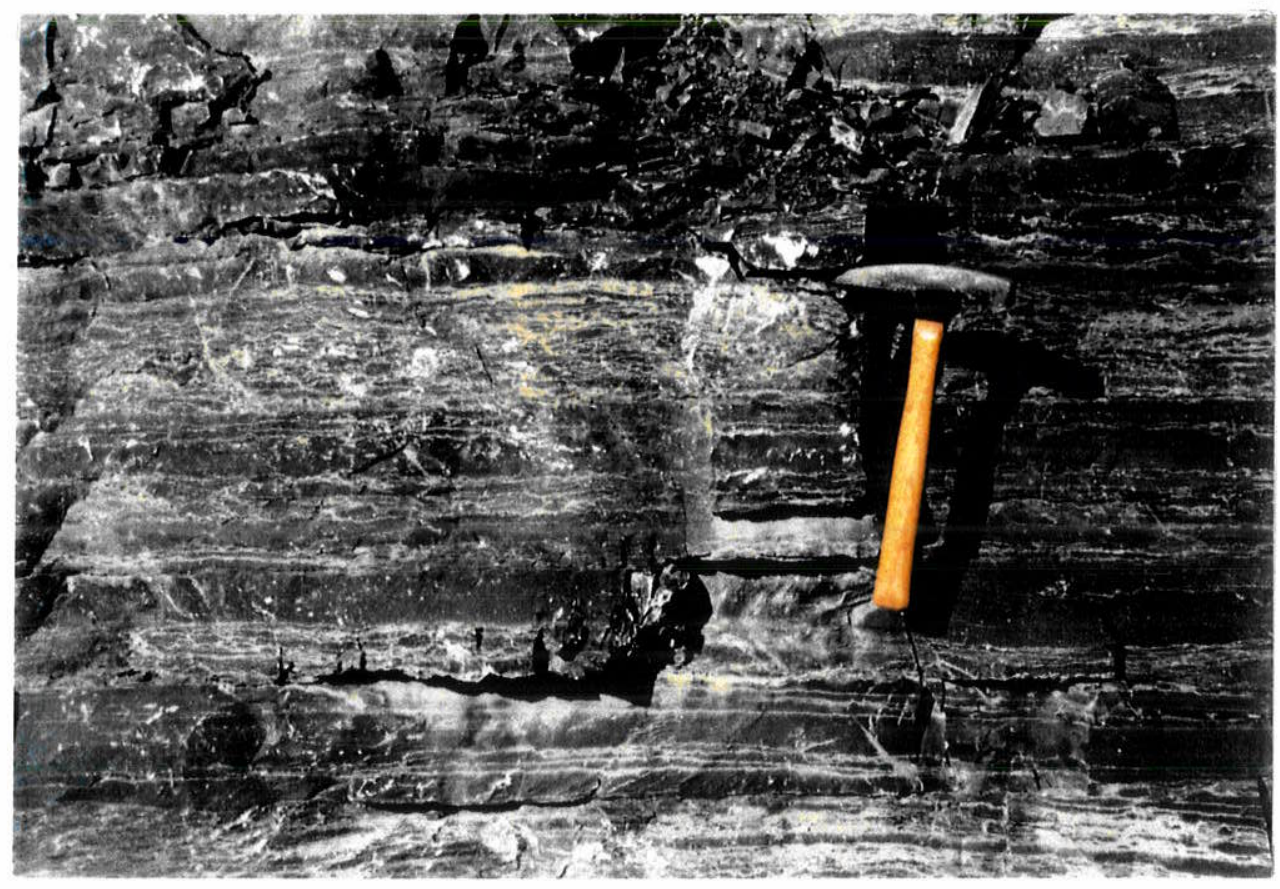

Foto 1 - Detalhe de exposição do calcário microbiano críptico, onde pode ser observada a alternância de níveis maciços e compactados (Fácies $\mathrm{Cm}$ ). Mina da Bocaina, Perfil 1. Cota 700 metros.

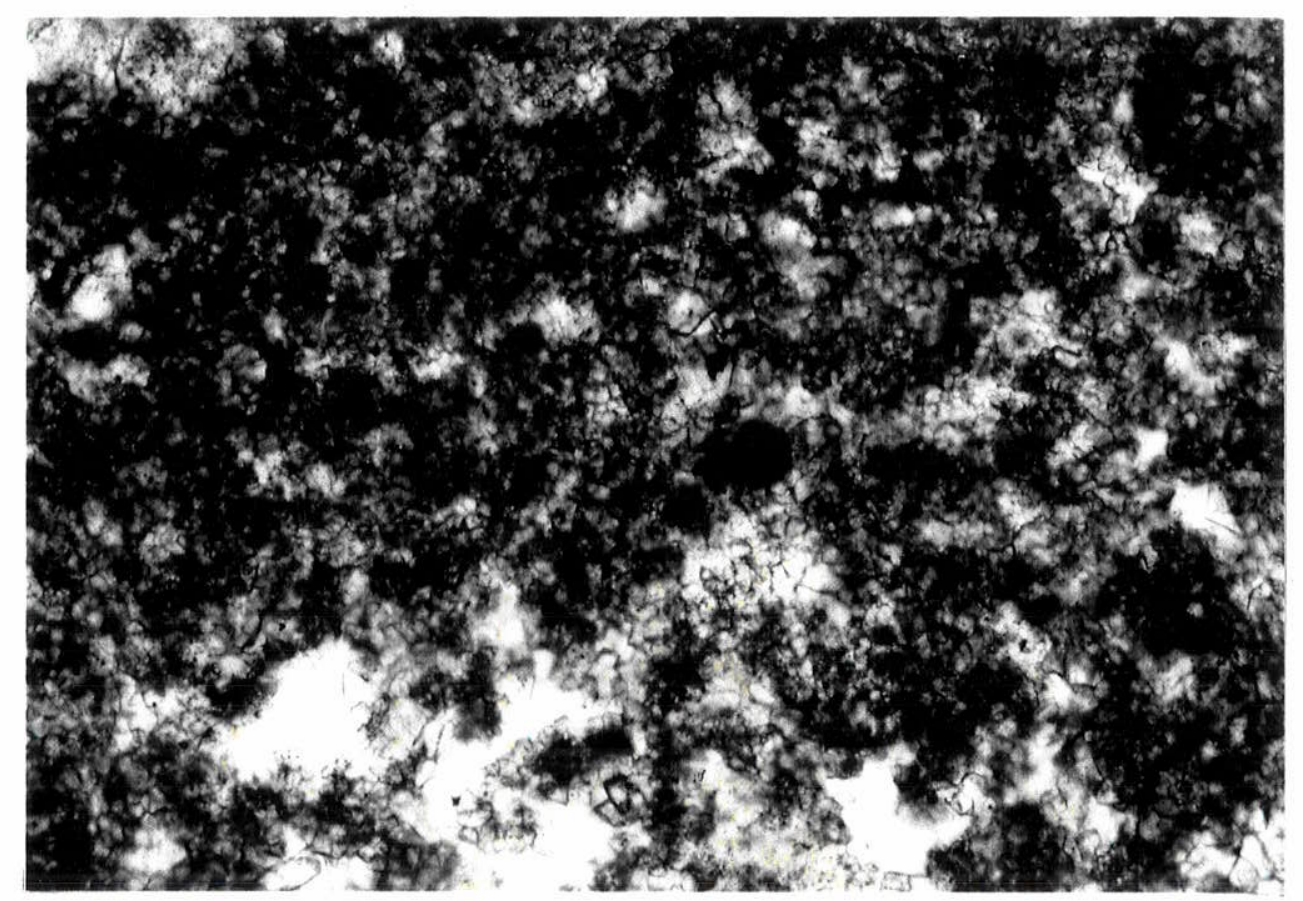

Foto 2 - Fotomicrografia de calcário microbiano críptico (Fácies $\mathrm{Cm}$ ), com microestrutura semelhante à Porostromata. L.N. $65 x$ 
argiloso associado à matéria carbonosa, que quando alterados formam uma película esbranquiçada. Análise por Difratometria de Raios X, identificou nesse material residual os seguintes argilominerais: illita, esmectita, camada mista irregular de illita-esmectita e caolinita. No calcário foram encontrados os mesmos argilominerais mais a presença de clorita, enquanto desaparece a caolinita.

Macroscopicamente, o calcário apresenta textura muito fina e não exibe estruturas organossedimentares.

Petrograficamente observa-se que tanto os niveis compactados quanto os maciços apresentam laminação incipiente, ou não são laminados. Quando o carbonato tem aspecto laminar, é resultante da alternância de níveis com laminação fenestral, isto é, da recorrência de leitos com inúmeras cavidades en rede alinhadas paralelamente do calcário, o que caracteriza, segundo Monty (1976) uma laminoid fenestral fabric, e não pode ser caracterizada como um laminação, a exemplo do que se observa nos estromatólitos . A alternância de níveis que apresentam laminação fenestral com níveis maciços ou com poucas cavidades ou lamosos, também dá ao calcário um aspecto laminar (Prancha 8, foto 2).

As cavidades no geral são alongadas ou irregulares, pequenas; algumas cavidades possuem teto digitado, base plana e apresentam semelhanças com stromatactis, embora sejam feições microscópicas (Prancha 7). Em nenhum caso as cavidades apresentam sedimento interno, sendo cimentas por calcita espática (Prancha 6, foto 2; Pranchas 7 e 8).

Quanto à microestrutura, o calcário microbiano criptico apresenta padrões variados, primários, pois não mostram evidências de resultarem de processos mecânicos e são semelhantes às encontradas em bioconstruções criptalgais (Aitken 1967) de águas rasas, com microfábrica micrítica, peloidal ou grumosa e cimentação precoce, sinsedimentar.

Em algumas lâminas delgadas, observa-se um aglomerado de grãos globulosos e de contorno micrítico, com diâmetros variando entre $30 \mu \mathrm{m}$ e $50 \mu \mathrm{m}$, que mostram semelhança com a microestrutura Porostromata (Pia 1929 apud Monty 1981), em especial com a descrita por Bertrand-Sarfati \& Moussine-Pouchkine (1983), em Gourma, na África (Prancha 6, foto 2), o que poderia caracterizar uma biofábrica celular (Hofmann 1969).

Freqüentemente, observa-se que a microestrutura é constituida por "grãos" micríticos ou de contorno micrítico, de seção subcircular, alongada ou irregular; eventualmente os diâmetros das seções alongadas são compativeis com as seções subcirculares $(70 \mu \mathrm{m}$ a $100 \mu \mathrm{m}$ ), o que poderia indicar a presença de microorganismos filamentosos (Prancha 8, foto 1). Esses "grãos" podem ainda formar agregados semelhantes a clusters ou apresentar vaga semelhança com formas descritas como Renalcis Vologdin, consideradas 


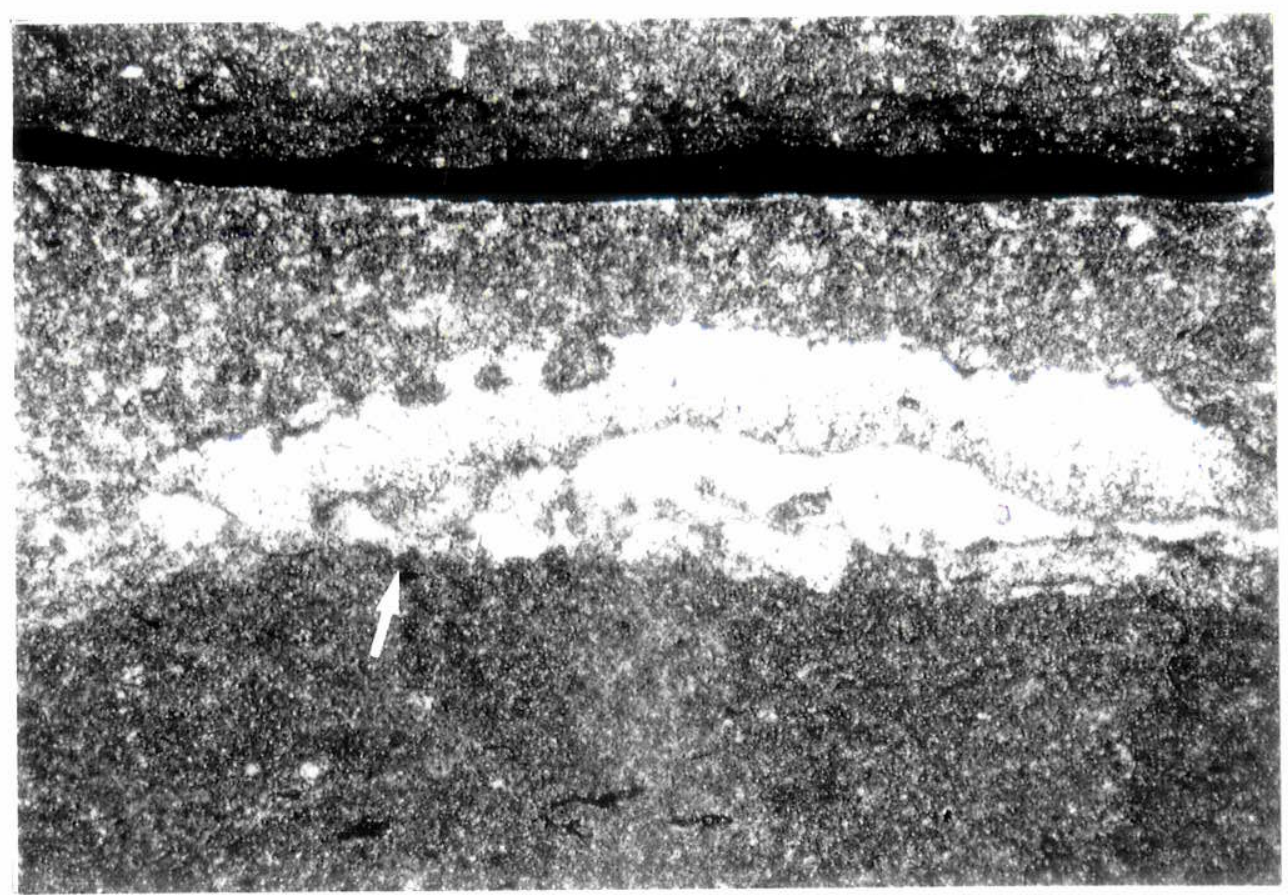

Foto 1 - Fotomicrografia de cavidade semelhante a stromatactis, de base plana e teto digitado, preenchida por calcita espática (seta), em calcário microbiano críptico associado a calcissiltito peloidal (Fácies Cs). L.N. 20x

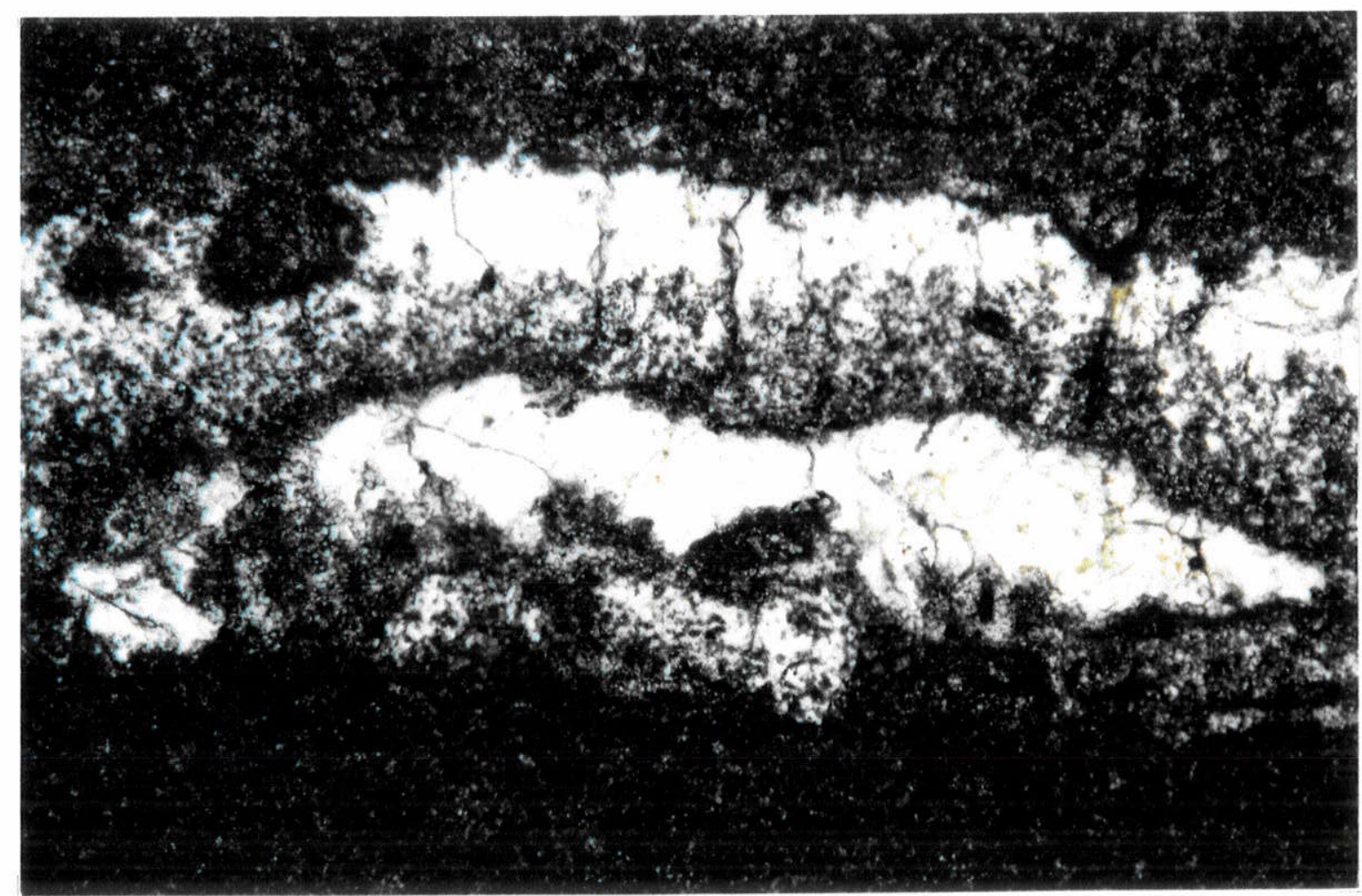

Foto 2 - Fotomicrografia mostrando detalhes da foto 1 . X.N. 60x 


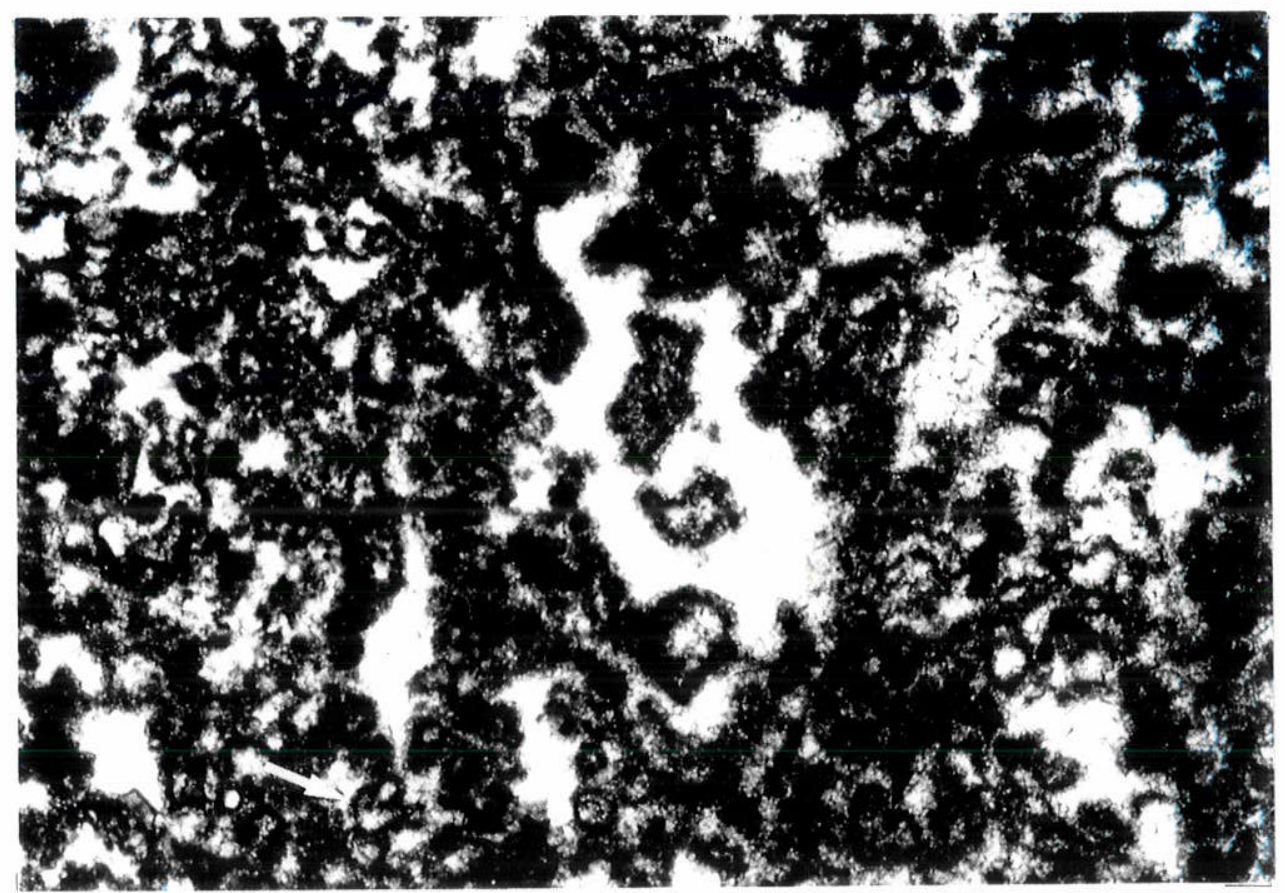

Foto 1 - Fotomicrografia de calcário microbiano críptico (Fácies Cm), que apresenta microestrutura grumosa a peloidal; observa-se ainda grãos bem arredondados e de contorno micrítico, preenchidos por calcita espática, bem como formas vagamente semelhantes a Renalcis (seta). L.N. $25 x$

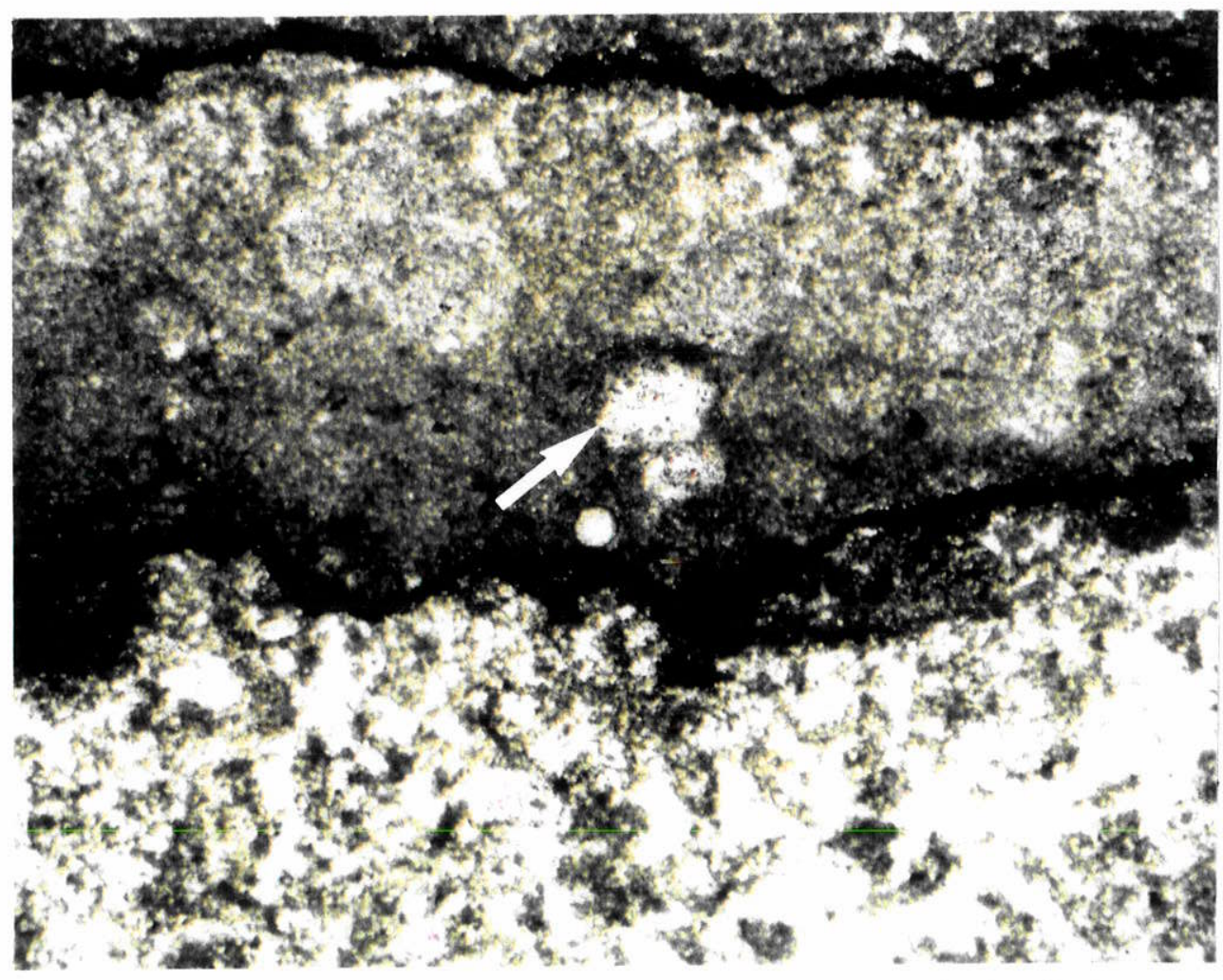

Foto 2 - Fotomicrografia de calcário microbiano críptico (Fácies Cm), onde se observa alternância de leitos com inúmeras cavidades e leitos lamosos; grão de contorno micrítico preenchido por calcita espática; silicificação (seta) em pequena área. P.G./L.N. 20x 
por Riding (1991) como prováveis cianobactérias calcitizadas, ou por Pratt (1984) como microfósseis diagenéticos, formados a partir da calcificação de células cocoidais, relacionadas a cianobactérias, em estágios diversos de decomposição.

Observa-se ainda, dispersos nos níveis microbianos, "grãos" de seção circular a subcircular, micríticos ou de contorno micrítico, prenchidos por calcita espática. Apresentam diâmetro variando entre $100 \mu \mathrm{m}$ e $185 \mu \mathrm{m}$, existindo, no entanto raros "grãos" com até $320 \mu \mathrm{m}$ de diâmetro. No geral não estão deformados, mas não são raros os casos em que isso acontece. Não foram encontradas evidências de que possam representar estruturas tubulares ou microorganismos filamentosos. Poderiam representar microorganismos cocoidais (Prancha 8, fotos 1 e 2).

Lentes decimétricas, isoladas, de sílex preto săo observadas em alguns horizontes; pequenas concreçōes constituídas por microquartzo ocorrem principalmente nos niveis lamosos, ricos em argilominerais.

Não foram observadas feições que sugerissem compactação sinsedimentar.

Dolomitização ocorre de modo muito incipiente, mas esporadicamente observa-se pequenas cavidades contendo dolomita barroca, limitadas por estilólitos.

Análises palinológicas efetuadas em níveis argilosos compactados, identificaram exemplares de acritarcas, pertencentes aos gêneros Kildinosphaera e Stictosphaeridium (Prancha 13).

Intercalados no calcário microbiano críptico ocorrem diversos níveis de calcarenitos e calcirruditos. Os calcirruditos constituem lentes descontínuas, de espessura centimétrica. São sustentados pelos clastos e foram observados apenas no Perfil 1. Os clastos são lamelares, milimétricos a centimétricos, e são constituidos por bioclastos de calcário microbiano criptico e intraclastos de calcissiltitos, calcilutitos e subordinadamente calcarenitos peloidais. Os clastos não apresentam deformação interna, e podem estar fortemente compactados, às vezes com contatos por suturas estilolíticas, ou imersos em matriz residual (Prancha 9).

As intercalações de calcarenitos apresentam espessuras centimétricas a métrica. Quando os calcarenitos constituem níveis delgados, são packstones e wackestones compostos por pelóides e bioclastos de calcário microbiano criptico de granulação fina a média. O pacote mais espesso de calcarenito ocorre no Perfil 2, na entrada da COMIG e tem cerca de um metro e meio de espessura. Dispöe-se em ciclos decimétricos, que apresentam a seguinte sucessão de estruturas sedimentares, da base para o topo: laminaçōes cruzadas por ondas, laminações onduladas de pequena amplitude e laminações plano-paralelas a onduladas, com discordâncias internas de baixo ângulo. 


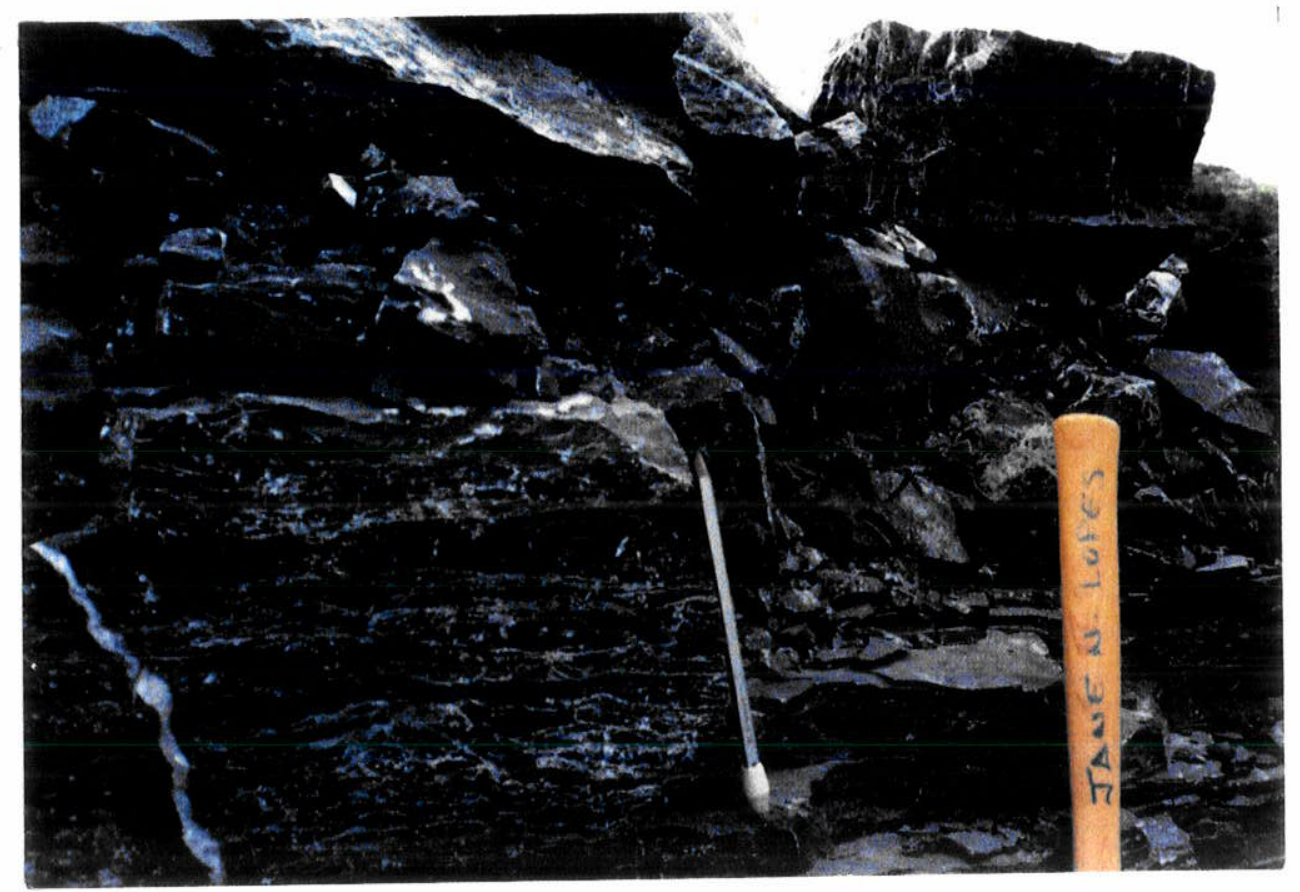

Foto 1 - Delgado nível brechóide intercalado no calcário microbiano críptico (Fácies Cm). Mina da Bocaina. Perfil 1.

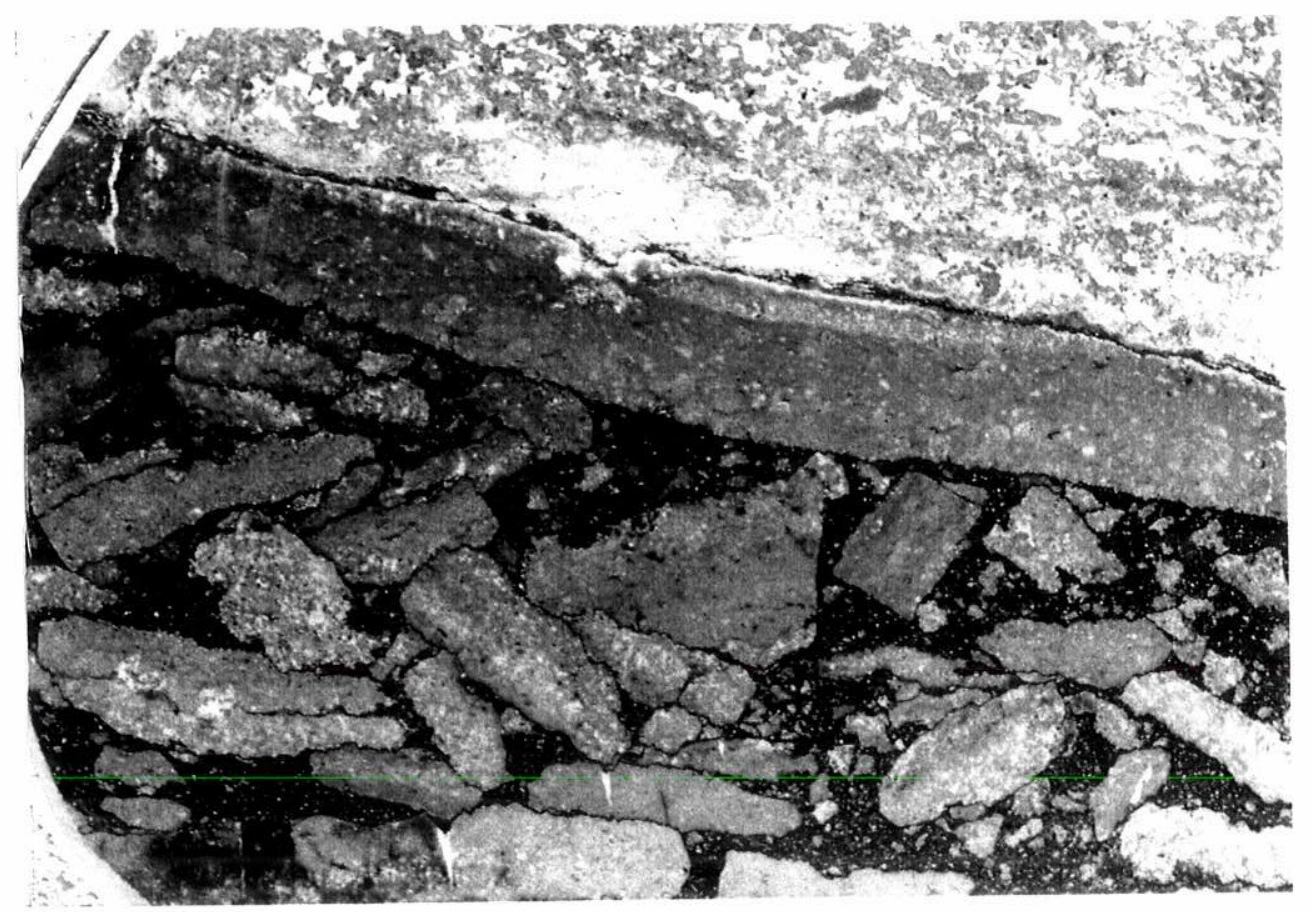

Foto 2 - Fotomicrografia do nível de calcirrudito observado na foto 1 , onde intraclastos, frequentemente limitados por suturas estilolíticas, estão imersos em matriz residual. L.N. $4 x$ 
Observa-se ainda truncamentos por ondulações de grande comprimento de onda. Petrograficamente, são grainstones a packstones, compostos por intraclastos de calcissiltitos e bioclastos de calcário microbiano críptico, de granulação fina a média; ocorrem ainda bioclastos representados pelos grãos de contorno micrítico, subcirculares ou deformados, preenchidos por calcita espática. Os calcarenitos têm arcabouço aberto e sofreram cimentação precoce (Prancha 10).

\section{2 - FÁCIES Cs: Calcissiltitos}

Os calcissiltitos foram observados em todas as seçōes, mas estão melhor representados na Mina da Bocaina (CSN)- Perfil 1, onde podem atingir cerca de 18 metros de espessura.

Regionalmente, os calcissiltitos apresentam intercalações freqüentes de calcirruditos não organizados (Fácies $\mathrm{Cr}$ ) e ocorrem sobrepostos ao calcário microbiano críptico (Fácies $\mathrm{Cm}$ ), em contato nítido, não gradacional. Exibem ainda delgadas intercalações de calcarenitos e de calcário microbiano críptico.

São de cor cinza escuro a preto e constituem niveis centimétricos a decimétricos, suborizontais. Em sua porção basal, na Mina da Bocaina, são argilosos (cerca de dois metros) e exibem padrőes de compactação semelhantes aos calcários microbianos cripticos; os contatos são ondulados, irregulares e contêm película de alteração esbranquiçada, constituída por argilominerais e matéria carbonosa residuais. Gradativamente, a proporção de minerais argilosos vai diminuindo e os niveis superiores apresentam contatos regulares, com superficie plana a ondulada.

Os calcissiltitos podem ser laminados, com laminações plano-paralelas a onduladas; laminações cruzadas ocorrem secundariamente e climbing ripples, não definidas se por onda ou corrente, foram observadas localmente em apenas um nível. Ocorrem ainda níveis de calcissiltitos maciços, não laminados (Pranchas 11 e 12 ).

Petrograficamente, observa-se que os calcissiltitos são peloidais, pelmicritos. Quando laminados, apresentam bandeamento milimétrico a submilimétrico, contato basal nítido e podem apresentar granodecrescência ascendente (Prancha 12, foto 1). Como estruturas de compactação, observa-se apenas raros estilólitos paralelos ao acamamento. Exibem pequenas cavidades preenchidas por calcita espática, originadas da dissolução de grãos, o que pode indicar presença de aloquímicos de composições diferentes (Prancha 12 , foto 2 ). 


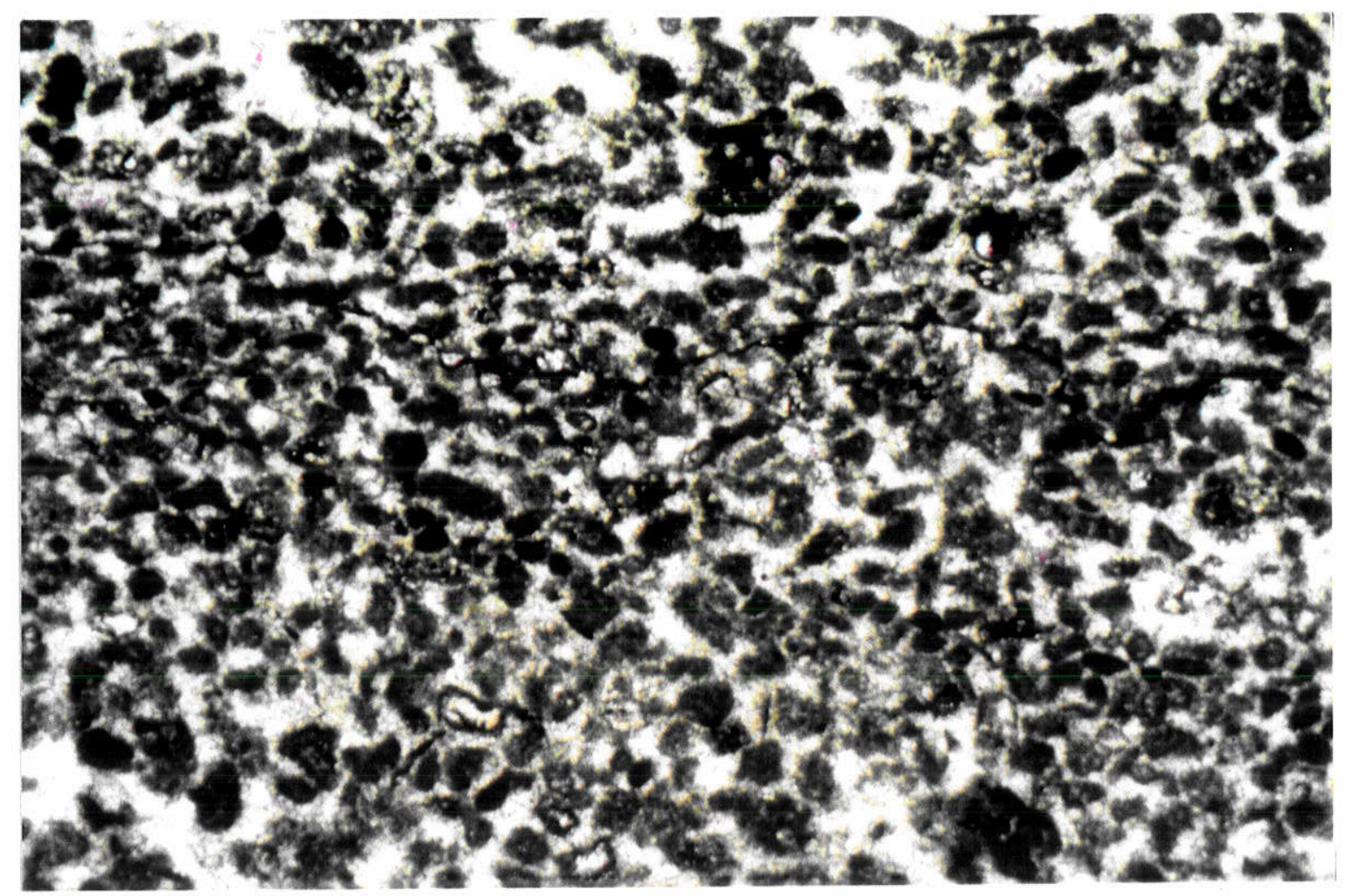

Foto 1 - Fotomicrografia de grainstone a packstone que ocorre associado ao calcário microbiano críptico (Fácies $\mathrm{Cm}$ ), no Perfil 2, na entrada da COMIG. P.G./X.N. 35x

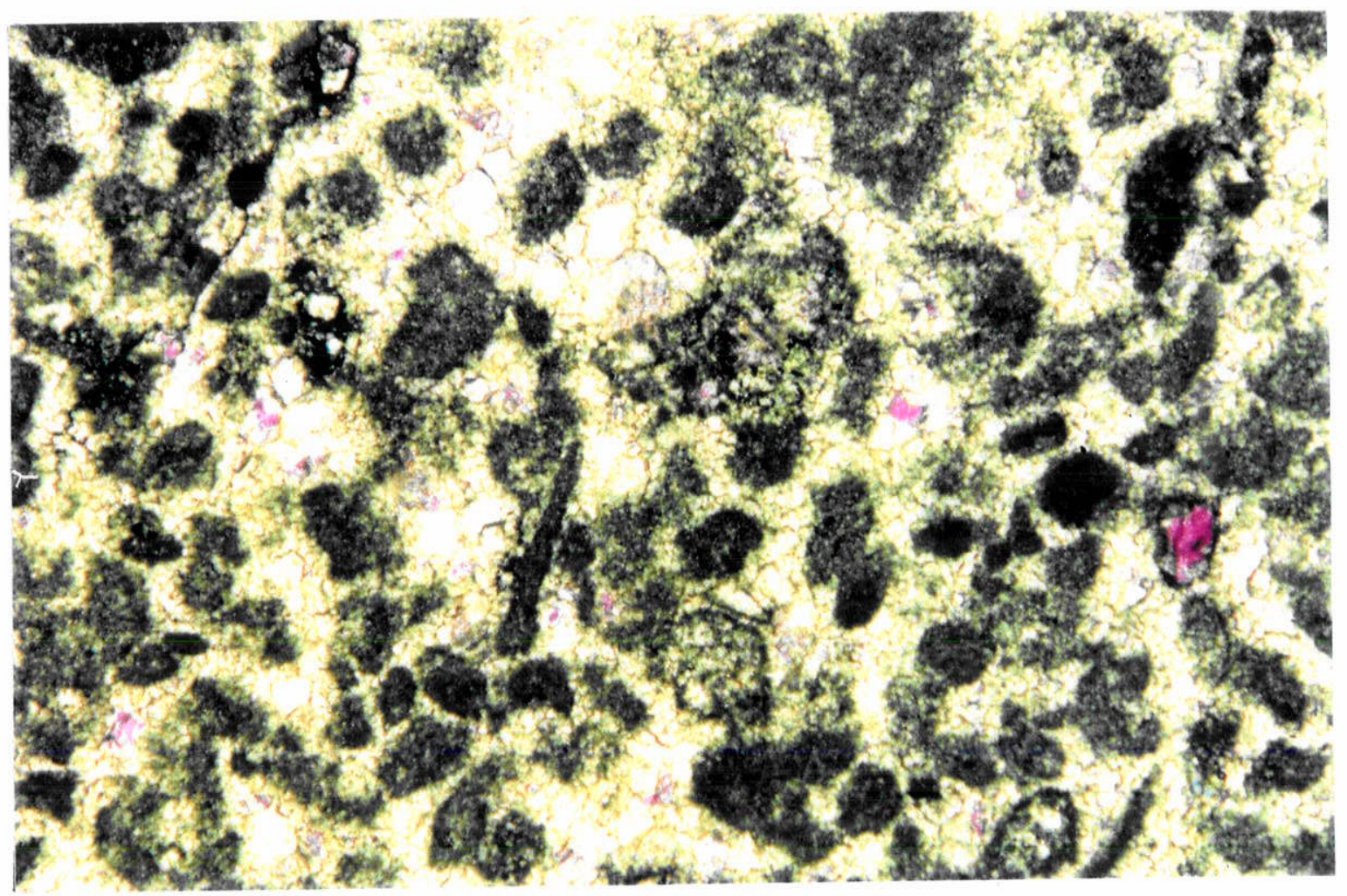

Foto 2 - Fotomicrografia de detalhe da foto acima, com bioclastos de calcário microbiano críptico e intraclastos de calcissiltitos. P.G./X.N. 65x 


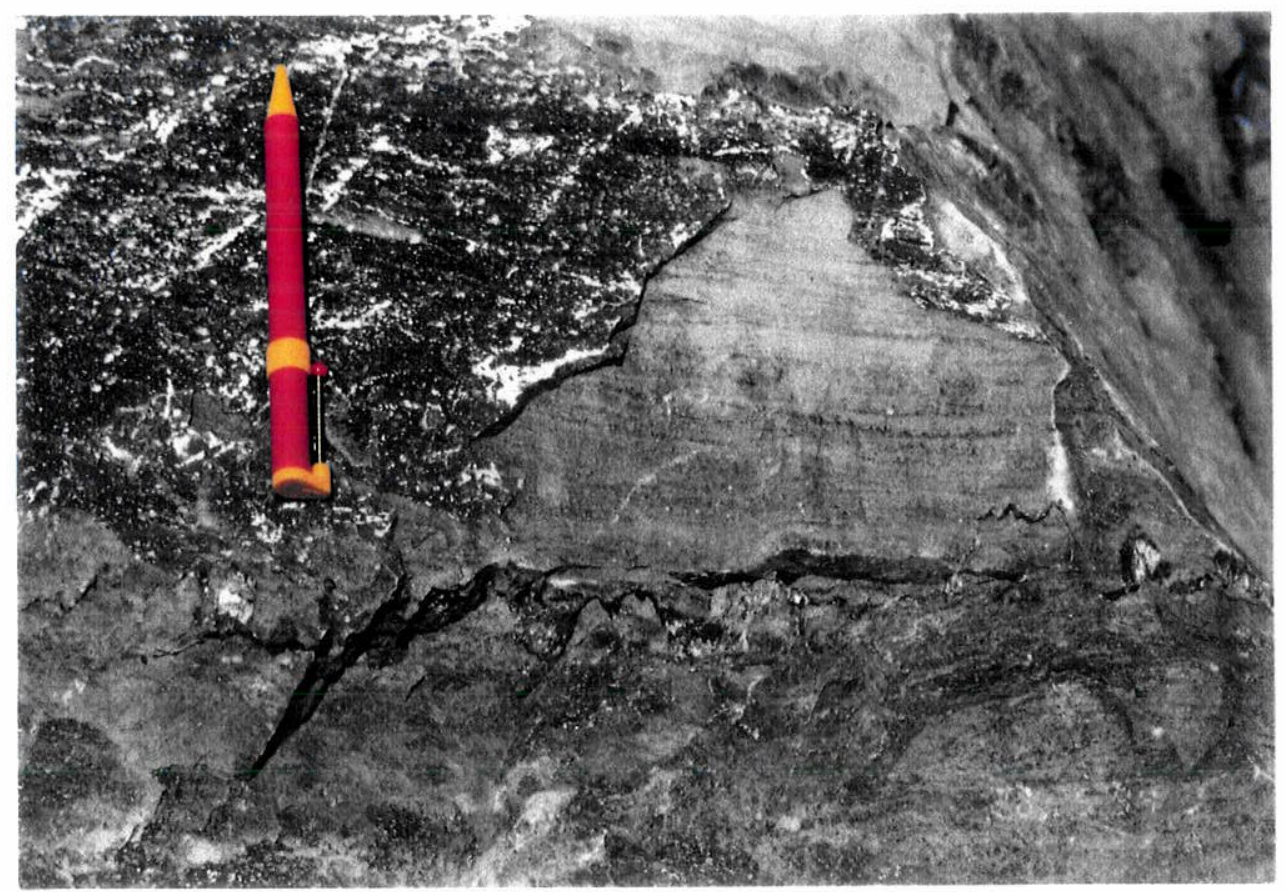

Foto 1 - Afloramento calcissiltito onde se observa laminação cruzada e granodecrescência ascendente (Fácies Cs). Mina da Bocaina, Perfil 1.

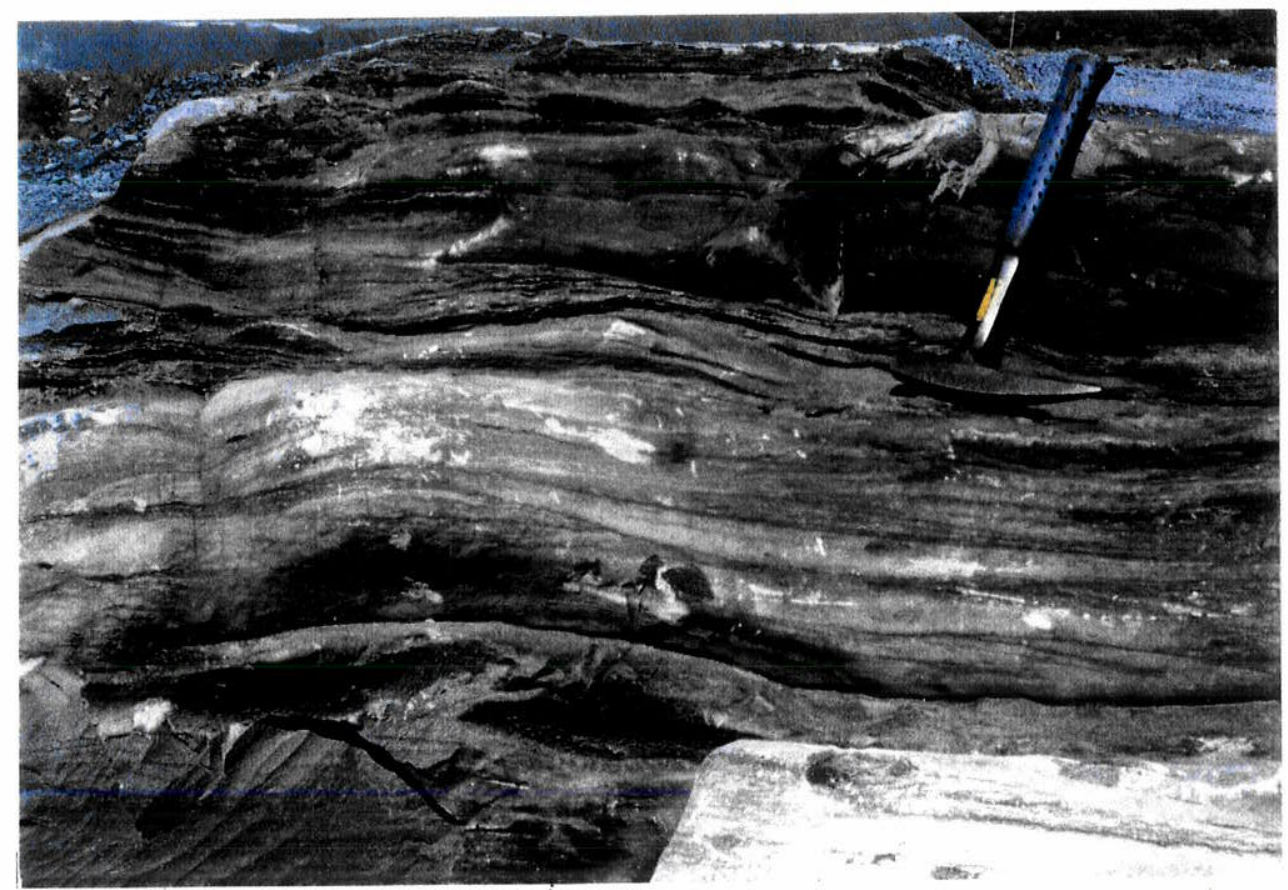

Foto 2 - Calcarenitos com estratificação cruzada por ondas truncadas por marcas onduladas de grande comprimento de onda (Fácies Cs). Perfil 1, Mina da Bocaina.

PRANCHA 11 


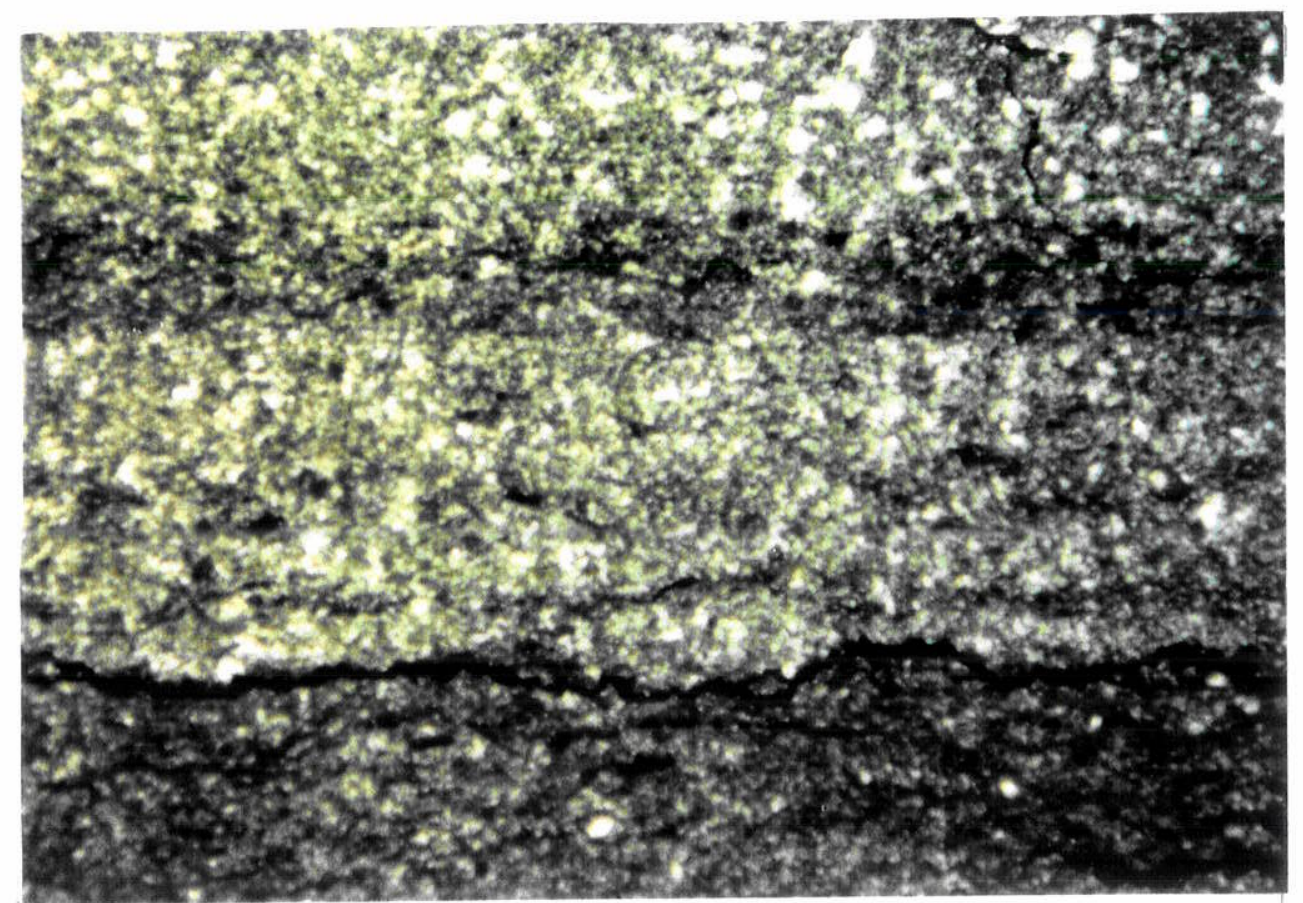

Foto 1 - Fotomicrografia de calcissiltito peloidal (pelmicrito), com laminação plano-paralela (Fácies Cs). Mina da Bocaina. Perfil 1. X.N. 30x

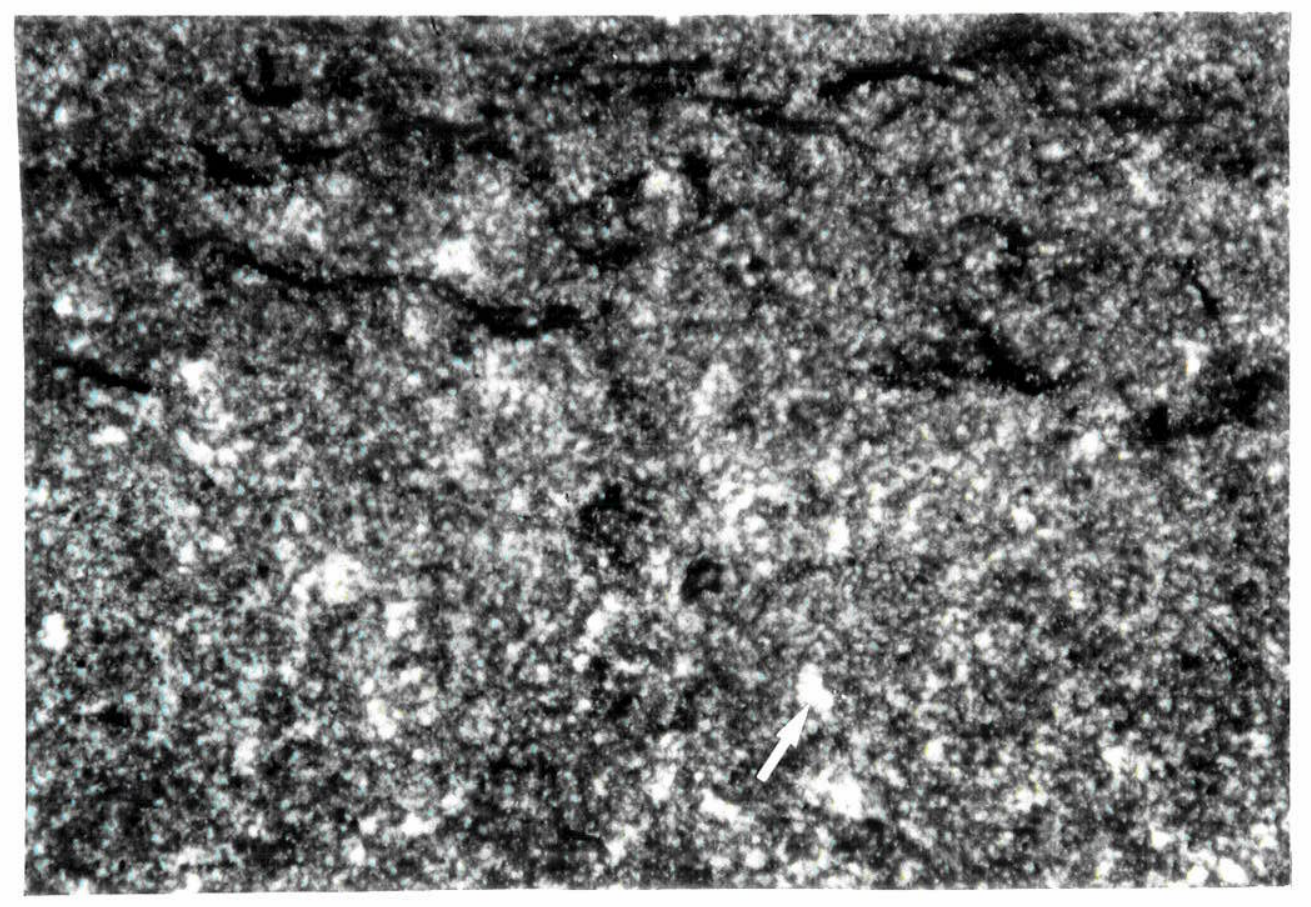

Foto 2 - Fotomicrografia de calcissiltito maciço (pelmicrito); observar dissolução de grãos, com preenchimento das cavidades por calcita espática (seta). Presença de dissolution seams descontínuos e delgados (Fácies Cs). Mina da Bocaina. X.N. 50x 
Os niveis de calcissiltitos maciços, não laminados, são de granulação mais fina, mais argilosos, e contêm mais matéria orgânica; como estruturas de compactação exibem inúmeros e delgados dissolution seams anastomosados e descontínuos; podem apresentar albita neoformada.

Os calcarenitos que ocorrem intercalados nos calcissiltitos constituem leitos delgados e são compostos por intraclastos de calcissiltitos e bioclastos de calcário microbiano críptico. Texturalmente são packstones, de granulação fina a média, mal selecionados. Calcarenitos finos, com estratificação cruzada e truncamentos por ondas de grande comprimento de onda (cerca de 1 metro), foram observados em blocos rolados (Prancha 11, foto 2).

Ainda intercalados nos calcissiltitos, sempre em contato nítido, são freqüentemente encontrados delgados níveis de calcário microbiano críptico.

Lentes decimétricas de sílex preto ocorem nos niveis mais argilosos que ocorrem próximos à base da fácies.

Análises palinológicas efetuadas nos níveis basais, mais argilosos, dos calcissiltitos, identificaram Acritarchae (Prancha 13), pertencentes aos gêneros Kildinosphaera, Trachysphaeridium, Stictosphaeridium e Protosphaeridium, além de espécimes em forma de vaso, filiados provavelmente a protistas heterotróficos. Ocorrem ainda formas com ornamentação em forma de apêndices, que não foram identificadas taxonomicamente.

\section{3 - FÁCIES Cr: Calcirruditos}

Regionalmente, os calcirruditos são caracterizados por ocorrerem intercalados nos calcissiltitos, compondo pares de contato nítido, não gradacional (Pranchas 14 e 15 ). No geral constituem camadas com espessura variando desde poucos centímetros até um metro. Alguns niveis basais constituem corpos tabulares extensos, podendo ser seguidos por até 100 metros.

Os calcirruditos apresentam também apresentar importante variação lateral como se observa no Perfil 1, na Mina da Bocaina, onde espesso pacote de calcirruditos com intercalações subordinadas de calcissiltitos grada a calcissiltitos com raras intercalações lenticulares de calcirruditos.

Os níveis rudáceos apresentam contato basal abrupto, planar ou ligeiramente irregular. Marcas de sola, gutter casts centimétricas, foram observadas apenas na base de uma camada no Perfil 2. 

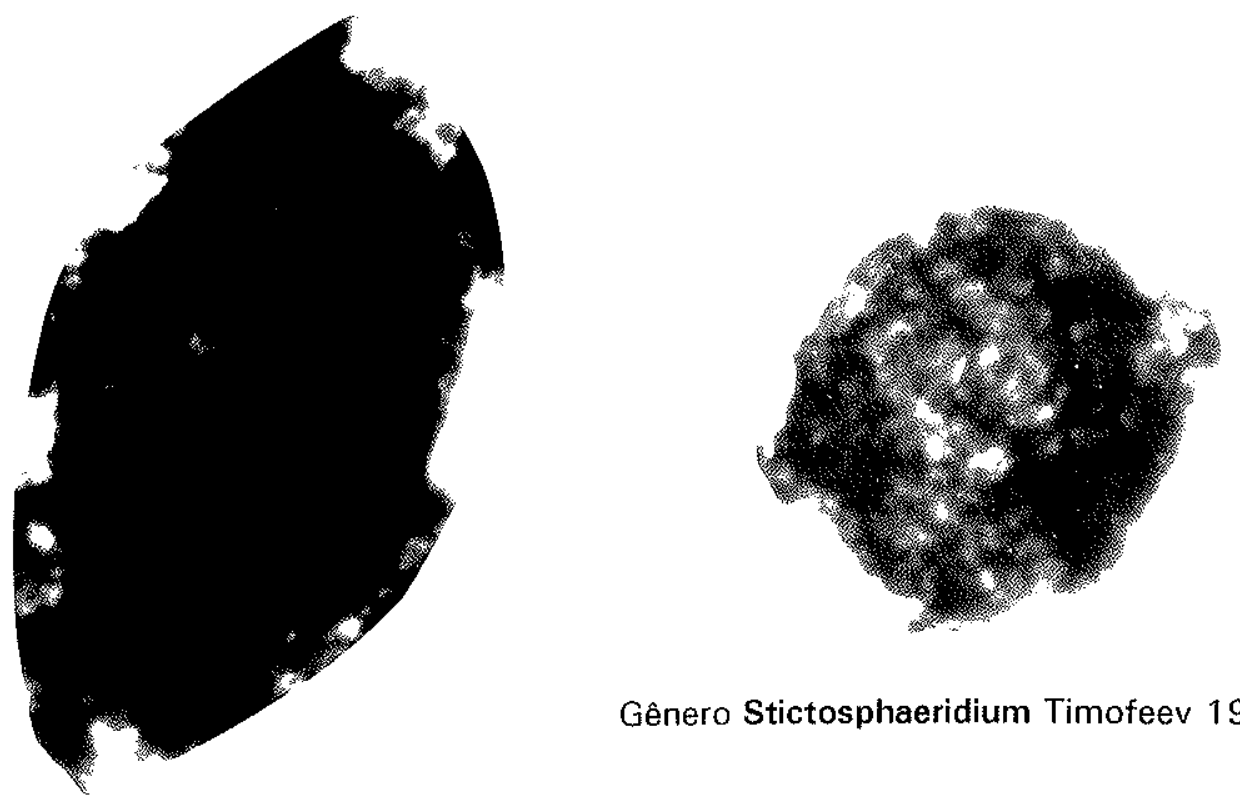

Gênero Stictosphaeridium Timofeev 1966

Gênero Trachysphaeridium Timofeev (1966) 1969
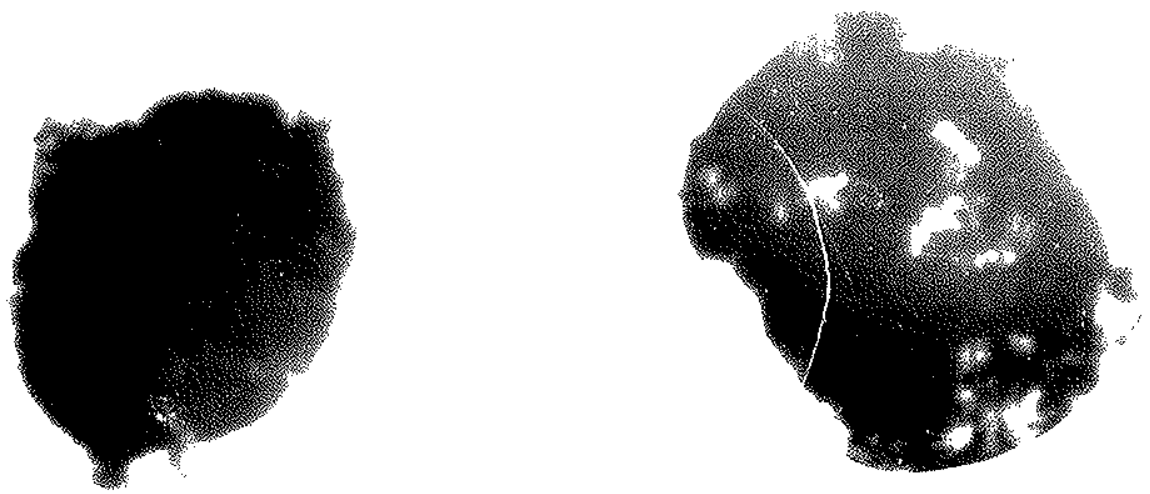

Gênero Kildinosphaera Vidal 1983

Gênero Protosphaeridium Timofeev 1966

0 $25 \mu \mathrm{m}$

Grupo Acritarcha Evitt 1963 


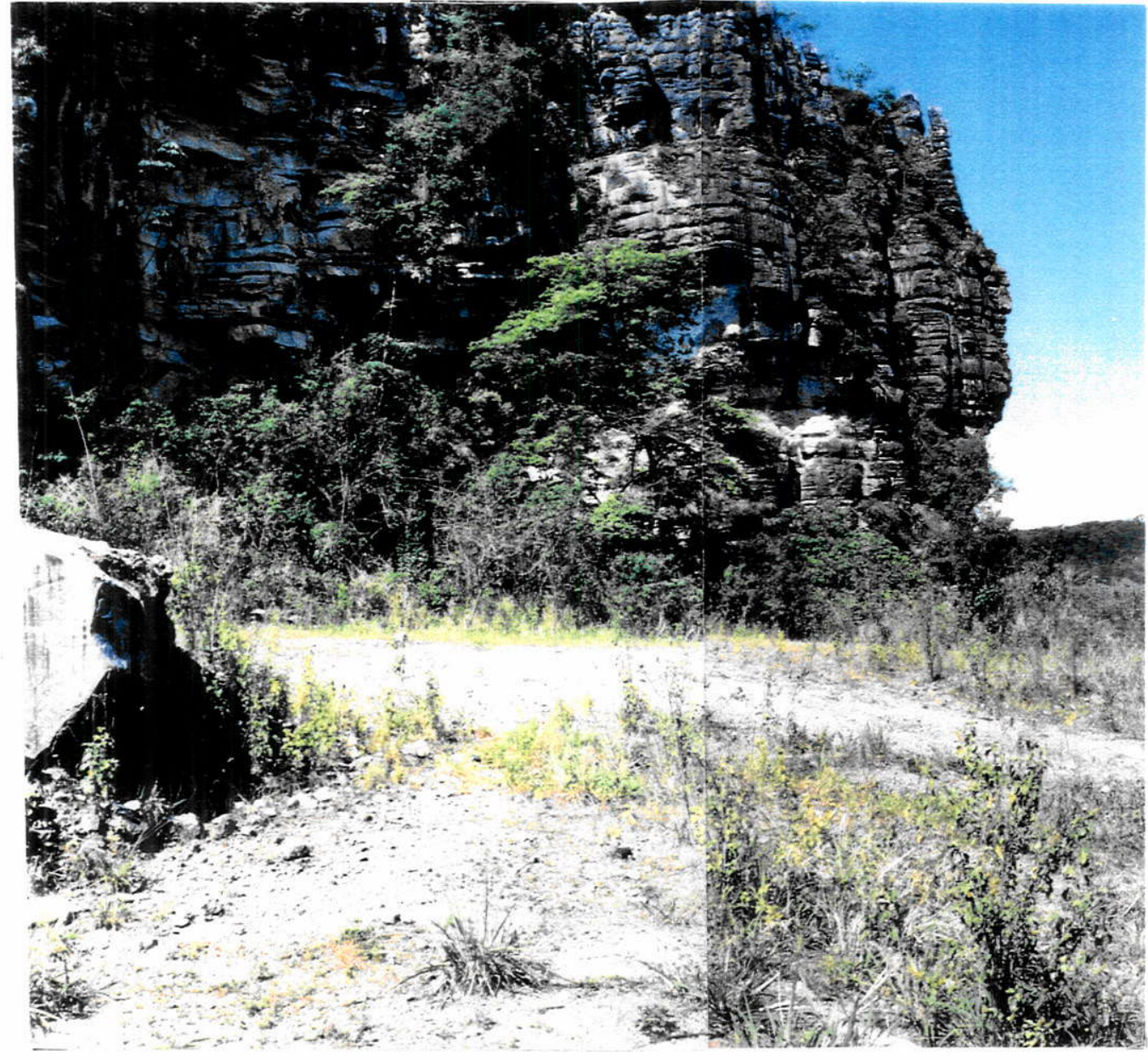

Foto 1 - Vista geral do Perfil 3, onde são acessíveis as fácies $\mathrm{Cm}, \mathrm{Cs}, \mathrm{Cr}$ Crf e parte da fácies CaDz. Mina abandonada da COMIG.

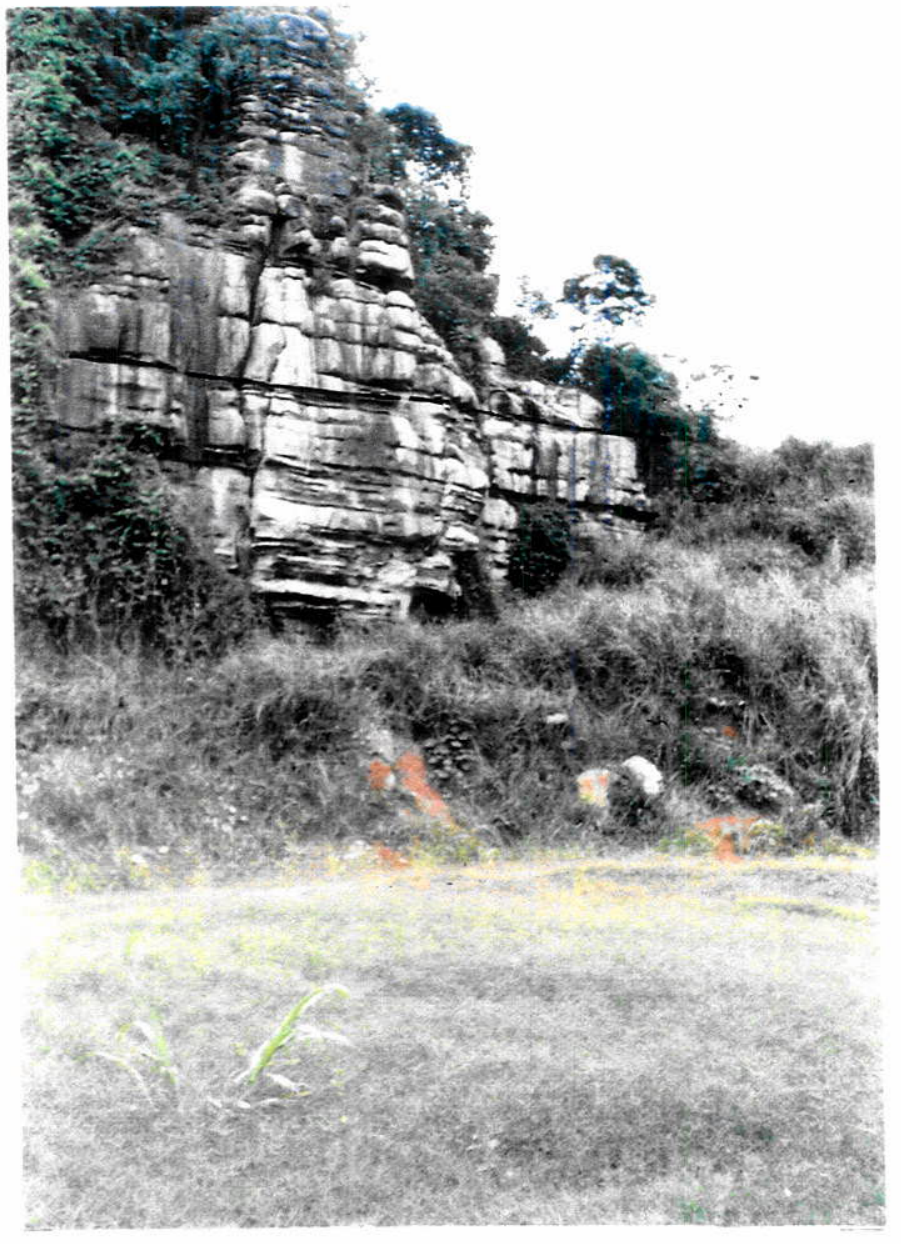

Foto 2 - Vista geral da parte superior do Perfil 2, na entrada da COMIG. onde afloram as litologias das fácies $\mathrm{Cr}$ e $\mathrm{Crg}$. 

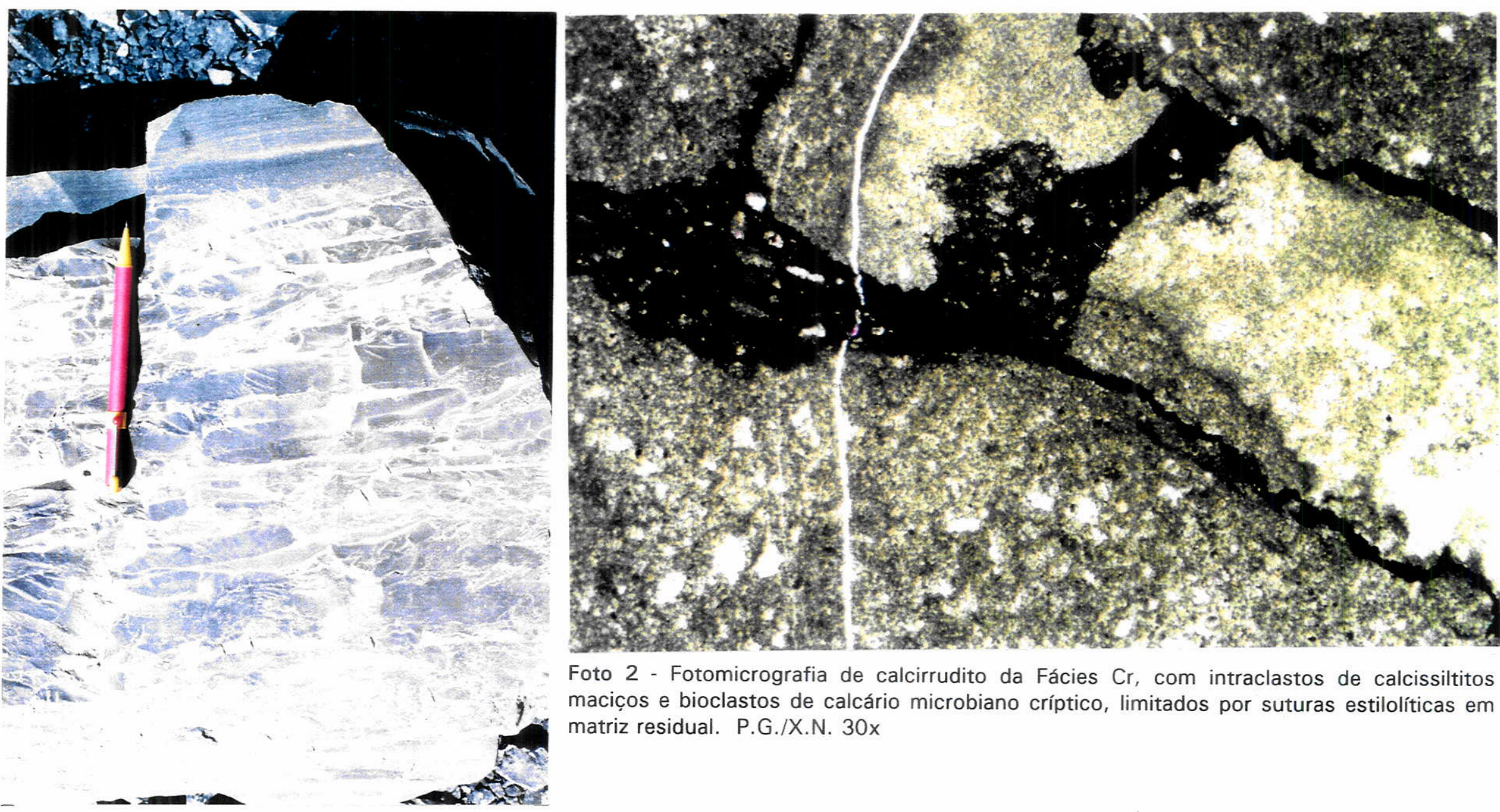

Foto 2 Fotomicrografia de calcirrudito da Fácies $\mathrm{Cr}$, com intraclastos de calcissiltitos maciços e bioclastos de calcário microbiano críptico, limitados por suturas estilolíticas em matriz residual. P.G./X.N. 30x

Foto 1 - Bloco de calcirrudito não organizado (Fácies $\mathrm{Cr}$ ), em contato nítido com calcissiltitos da Fácies Cs, na Mina da Bocaina, Perfil 1. 
Os calcirruditos são maciços, não organizados e estão sustentados pelos clastos. São rudstones. Os niveis mais delgados tendem a ter clastos menores. Raramente exibem gradação normal.

Os clastos são exclusivamente carbonáticos, sendo compostos predominantemente por intraclastos de calcissiltitos, maciços ou laminados e bioclastos de calcário microbiano críptico (Prancha 14, foto 2). Muito subordinadamente ocorrem intraclastos de packstones peloidais. Quanto à forma, são placóides, ovalados ou irregulares, subangulares a bem arredondados e apresentam dimensões variando de alguns milimetros a decímetros.

A matriz é arenosa, polimodal, de natureza intraclástica e bioclástica, ou lamosa. Certos niveis conglomeráticos praticamente não apresentam matriz. Estão fortemente compactados, com os intraclastos e bioclastos em contatos suturados por estilólitos; exibem ainda extensas áreas com dissolution seams que eventualmente contêm fragmentos submilimétricos de rocha carbonática fragmentada. Não se observou deformação plástica nos intraclastos.

Alguns niveis mais espessos de calcirruditos podem apresentar dolomitização parcial da matriz e eventualmente dos clastos menores.

\section{4 - FÁCIES Crg: Calcirruditos/ calcarenitos com gradação normal}

Estas rochas são mais expressivas no Perfil 2 (afloramento da entrada da COMIG), com cerca de 12 metros de espessura estimada (Figura 10) e nos perfis 3 (mina abandonada da COMIG) e 5 (estrada Arcos-Pains). Na Mina da Bocaina, esta fácies compõe um pacote de aproximadamente seis metros de espessura.

A Fácies $\mathrm{Crg}$ apresenta contato gradacional tanto com as fácies $\mathrm{Cr}$, e Cs, subjacentes, como CaCrD e Crf, de topo.

Os calcirruditos/calcarenitos exibem variação lateral de espessura e constituem ciclos decimétricos com granodecrescência ascendente; o contato basal de cada ciclo é abrupto, de natureza erosiva (Prancha 16, foto 1).

Internamente, os diversos ciclos desenvolvem os seguintes tipos de sucessão:

1) niveis com gradação normal; na base ocorrem conglomerados não organizados que gradam para calcissiltitos com laminação plano-paralela a ondulada no topo. Gradações inversas são raras, mas podem ocorrer, associadas a gradações normais.

2) níveis com granodecrescência ascendente, onde calcirruditos maciços gradam a calcissiltitos com laminação plano-paralela, sem que haja uma diminuição significativa nas 


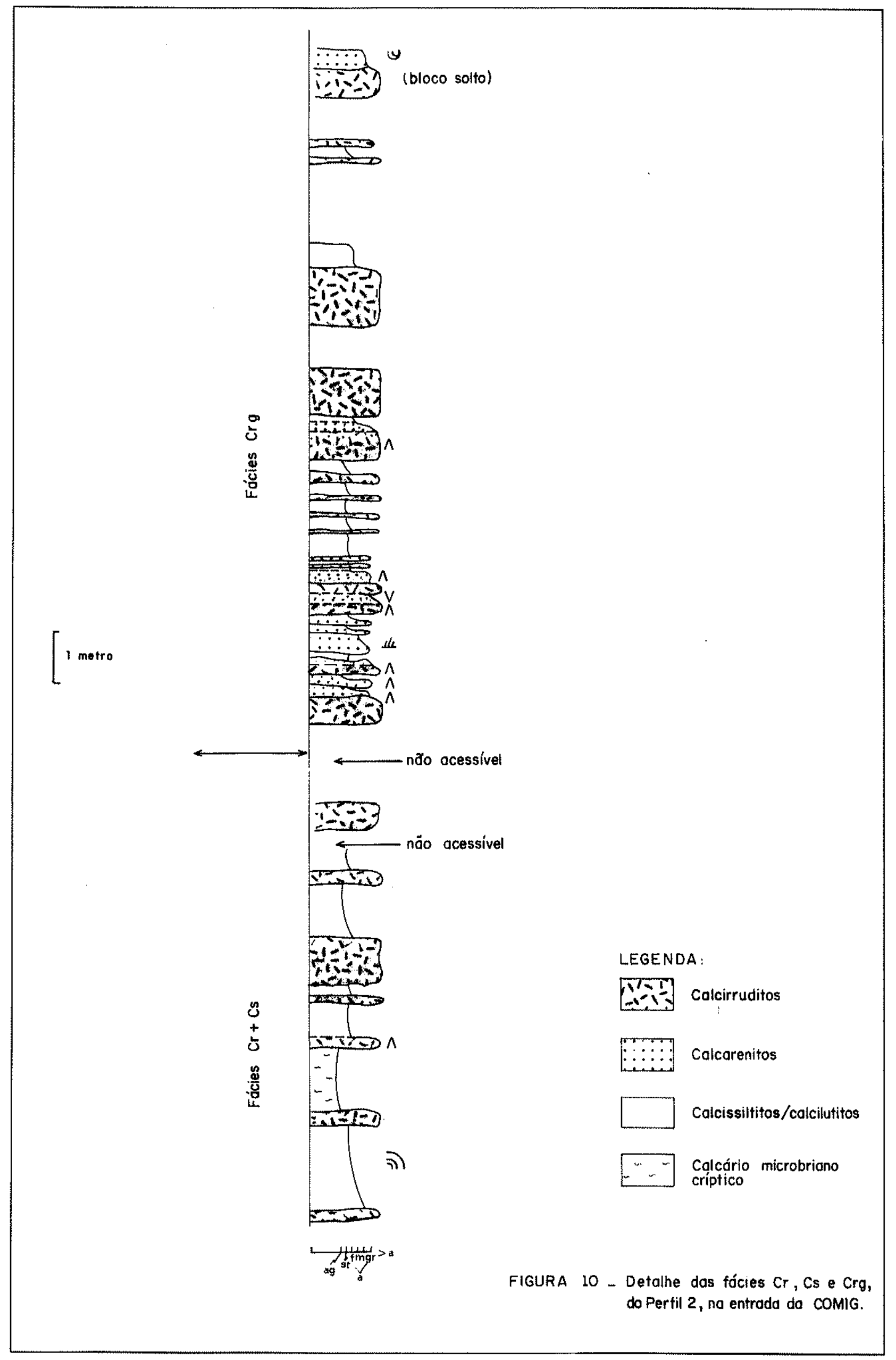




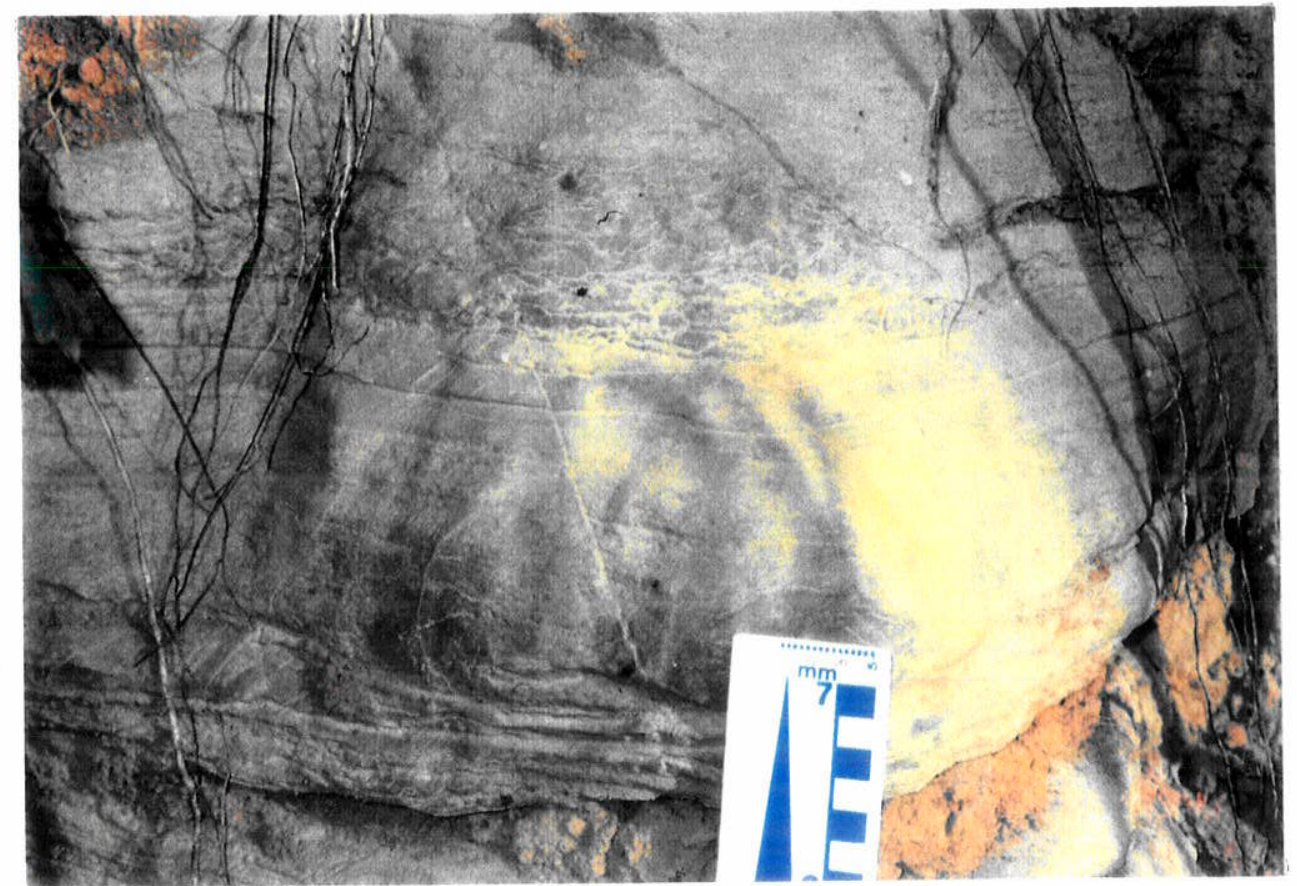

Foto 1 - Afloramento, no Perfil 5, de calcirrudito com gradação normal (Fácies Crg). Estrada Arcos-Pains.

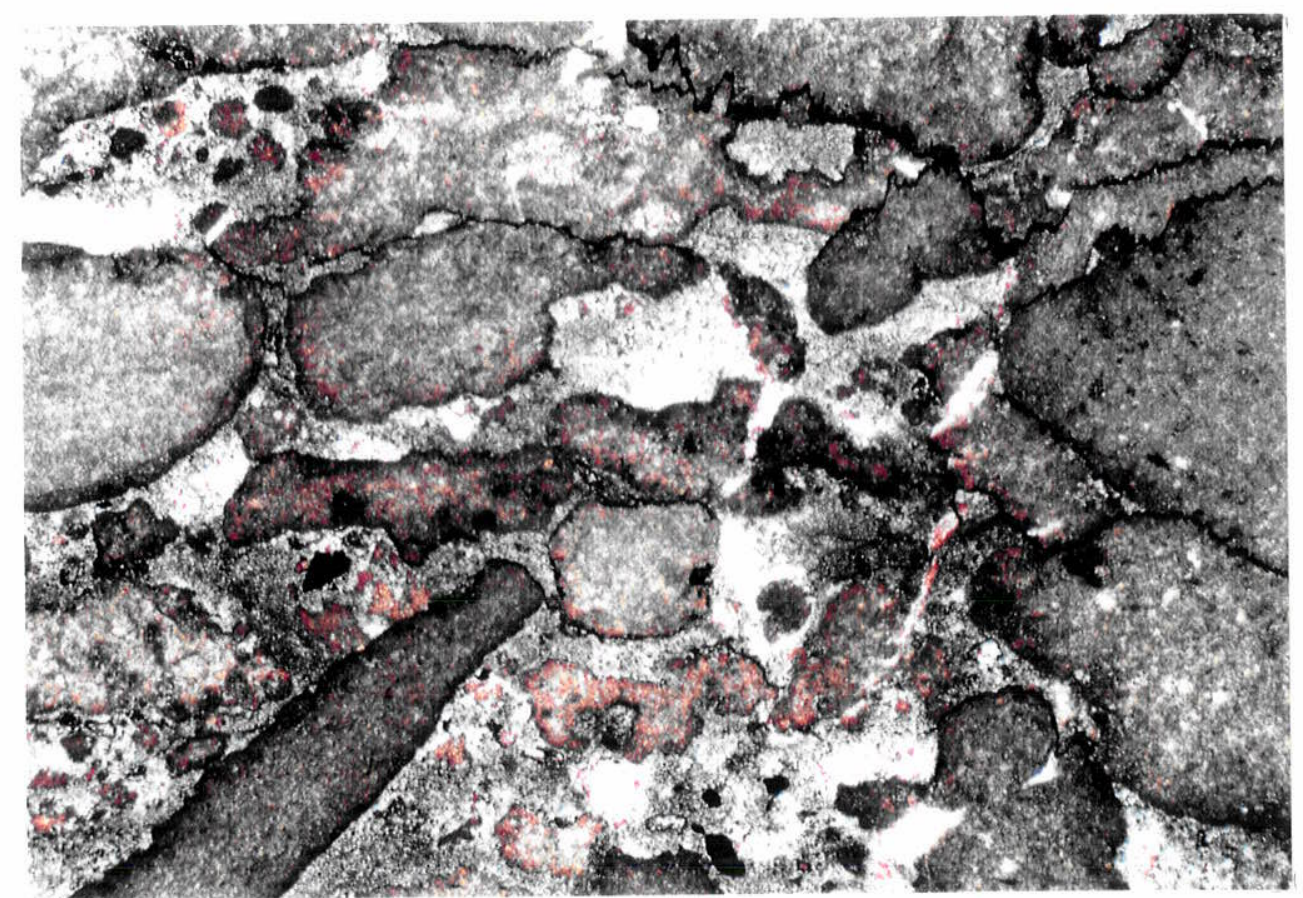

Foto 2 - Fotomicrografia de calcirrudito da Fácies Crg, com dolomitização parcial da matriz e dos clastos menores. A dolomitização pode alterar o contorno dos clastos, no geral limitados por suturas estilolíticas. Coloração por Alizarina. Perfil 2 - Afloramento da entrada da COMIG. X.N. 10x 
dimensōes dos intraclastos, que apenas se tornam mais escassos à medida que aumenta a proporção de finos. Neste caso, ocorrem alguns floatstones.

3) niveis com granodecrescência ascendente, compostos por leitos distintamente segregados em função da granulometria dos aloquímicos que os compõem. $\mathrm{Na}$ base dos ciclos geralmente ocorrem conglomerados com grânulos ou calcarenitos de granulação grossa, que passam a calcarenitos de granulação fina a muito fina, com laminações cruzadas, e a calcissiltitos com laminações plano-paralelas a onduladas com discordâncias internas de baixo ângulo.

Ocorrem ainda, subordinadamente, niveis de calcarenitos com pequenas marcas onduladas que gradam a calcissiltitos com laminaçōes plano-paralelas a onduladas $e$, eventualmente laminações cruzadas de baixo ângulo.

Os calcirruditos são conglomerados intraformacionais sustentados pelos clastos, que são milimétricos a decimétricos, arredondados; podem ser lamelares ou irregulares e alguns estão encurvados.

Os niveis rudáceos com grânulos, possuem clastos maiores subordinados, têm entre 10 centimetros e 30 centimetros de espessura e eventualmente ocorrem associados aos níveis de calcirruditos mais possantes e de granulação mais grossa.

Petrograficamente, os calcirruditos são compostos por intraclastos e bioclastos de composição carbonática. Podem apresentar arcabouço aberto, com matriz de granulação areia, polimodal, intraclástica a bioclástica, ou arcabouço fechado, quando os clastos apresentam contatos suturados, no geral por estilólitos. Os clastos são mais heterogêneos que na Fácies $\mathrm{Cr}$, embora a maioria deles ainda seja derivada das litologias adjacentes. Predominam os intraclastos de calcissiltitos e subordinadamente os biociastos de calcário microbiano (Prancha 16, foto 2). Observa-se no entanto um ligeiro aumento na proporção de clastos de packstones peloidais, e aparecem agora clastos policiclicos de calcirruditos.

Embora as seçöes descritas apresentem feições comuns, exibem também particularidades próprias.

Assim, na Mina da Bocaina (Perfil 1), predominam as sucessões descritas como tipos 1 e 2, com lama no topo dos ciclos.

No Perfil 2, na entrada da COMIG, são freqüentes os ciclos do tipo 3, com conglomerados com grânulos na base; para o topo da fácies os niveis de calcirruditos são mais espessos e de granulação mais grossa; alguns níveis de calcirruditos apresentam dolomitização parcial dos clastos e da matriz (Prancha 16, foto 2).

O Perfil 5 possue ciclos do tipo 1, com níveis de calcirruditos mais espessos e de granulação mais grossa para o topo da fácies. 
No Perfil 3, na mina abandonada da COMIG, não foram observadas laminações cruzadas por ondas, apenas pequenas e raras marcas onduladas próximo ao topo da unidade, quando ocorrem sedimentos finos. Os niveis conglomeráticos aí se distribuem de modo regular, sem grandes variações de espessura.

Delgados niveis de calcário microbiano criptico podem ocorrer intercalados entre as sucessōes descritas.

Nos perfis 2 e 5 , em blocos soltos, observa-se espessas camadas de calcirrudito não organizado, contendo intraclastos encurvados, sendo recobertas, em contato nítido, por calcarenitos com estratificação acanalada de médio porte (cerca de 30 centímetros).

\section{5 - FÁCIES Crf: Calcirruditos sustentados pela matriz}

Esta fácies apresenta cerca de 6 metros de espessura e ocorre apenas no Perfil 3 , na mina abandonada da COMIG, em contato gradacional com as fácies $\mathrm{Crg}$ e $\mathrm{CaDz}$.

Tem como principal caracteristica a ocorrência de delgados niveis de calcirruditos sustentados pela matriz, que pode ser calcarenítica ou calcilutítica (Prancha 17).

Os niveis brechóides são subhorizontais, centimétricos a decimétricos, e têm limites difusos. Podem ocorrer associados a niveis de calcirruditos mais espessos e de base erosiva, sustentados pelos clastos e com gradação normal, sendo semelhantes aos descritos na Fácies Crg; nesse caso ocorrem floatstones na parte superior do nível.

Nos dois metros basais, os niveis brechóides ocorrem associados a calcarenito ou calcirrudito com grânulos, maciços; para o topo, o calcário torna-se mais escuro, de granulação fina, e os intraclastos estão imersos em matriz carbonática lamosa.

Próximo ao topo da fácies, diminuem as intercalações brechóides e a matriz, composta por calcilutito, apresenta delgadas lentes arenosas com laminações cruzadas por ondas. Progressivamente passa a predominar a fração areia, com raras lentes de lama carbonática, gradando para o calcarenito dolomítico sobrejacente (Fácies CaDz).

No geral, tanto o calcarenito quanto o calcilutito onde se inserem os níveis brechóides têm aspecto maciço. Muito raramente, observam-se laminações cruzadas ou pequenas marcas onduladas.

Petrograficamente, observa-se que os calcirruditos são constituídos por intraclastos de calcissiltitos e de calcarenito peloidal; mais raramente, ocorrem intraclastos policíclicos de calcirruditos. 

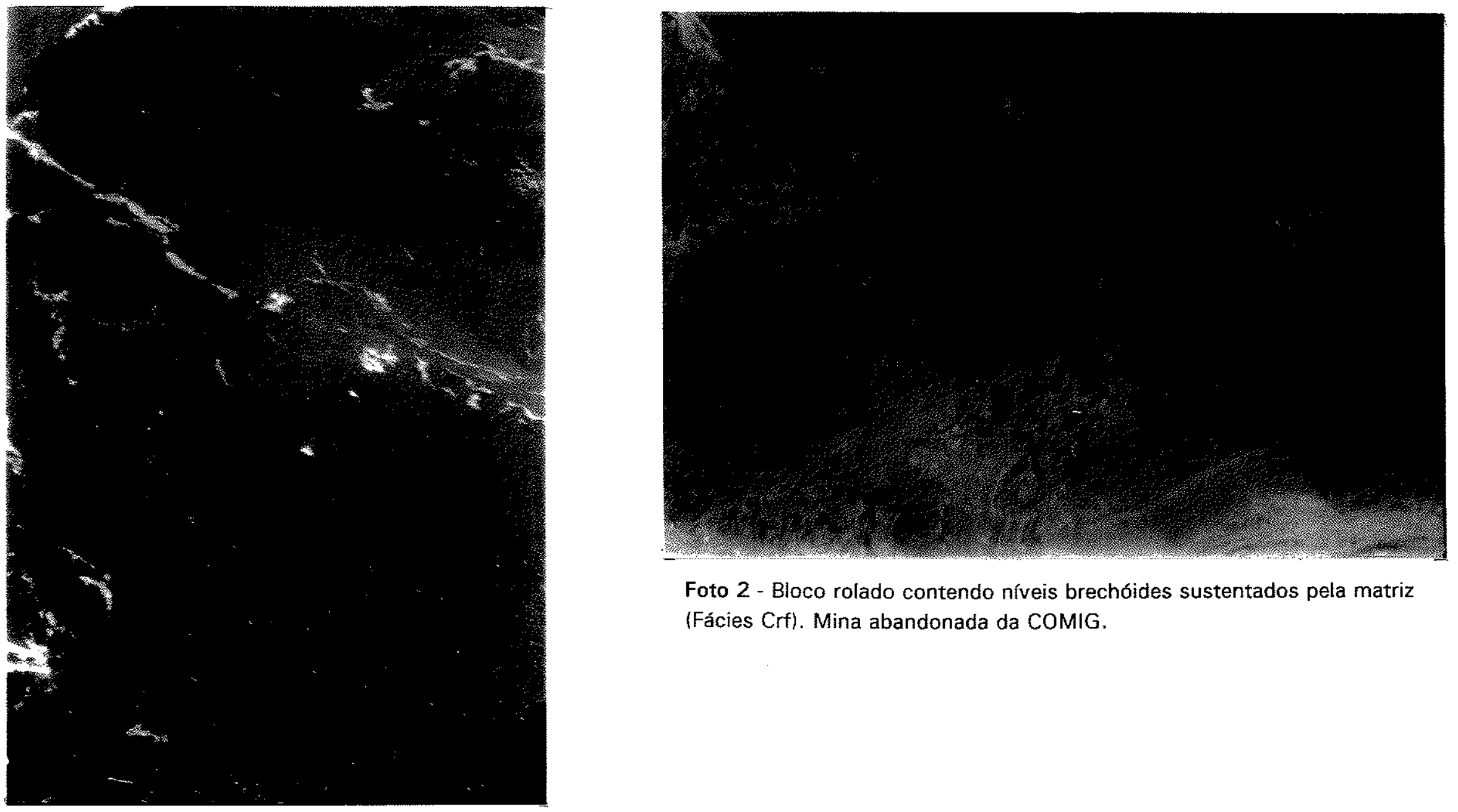

Foto 2 - Bloco rolado contendo níveis brechóides sustentados pela matriz (Fácies Crf). Mina abandonada da COMIG. 
Os calcirruditos sustentados pelos clastos podem ou não conter matriz; se presente, a matriz é arenosa, polimodal; na ausência de matriz, os intraclastos apresentam contatos suturados por estilólitos. Não se observou dolomitização nos clastos ou na matriz.

Os calcirruditos na fração grânulos são maciços e mal selecionados. Os clastos são placóides, irregulares, alguns extremamente delgados, e podem ser subangulares a subarredondados; são compostos por intraclastos de calcissiltitos, calcilutitos, calcarenito peloidal e bioclastos de calcário microbiano críptico.

O calcarenito é um packstone mal selecionado, composto por aloquímicos micríticos, arredondados a subarredondados.

Os calcilutitos apresentam-se fortemente neomorfizados e podem gradar para wackestones.

5.6 - FÁCIES CaCrD: Calcarenitos/calcirruditos dolomíticos com granodecrescência ascendente

Esta fácies apresenta contato gradativo com as fácies $\mathrm{Crg}$ e $\mathrm{CaDz}$ na Mina da Bocaina (Perfil 1), onde tem cerca de 10 metros de espesssura; aflora ainda na estrada Arcos-Pains (Perfil 5), em cortes isolados.

Os niveis de calcarenitos e/ou calcirruditos dolomiticos têm espessura centimétrica a decimétrica, são amalgamados e exibem granodecrescênçia ascendente. Apresentam contato basal brusco, de natureza erosiva, e compöem ciclos que têm na base calcarenitos grossos ou calcirruditos, que gradativamente passam a calcarenitos de granulação mais fina e eventualmente a calcissiltitos

A seqüência típica de estratificação nesses níveis é de laminação plano-paralela, laminação ondulada cruzada por ondas, laminação ondulada e laminação plano-paralela a ondulada quando existe material lamoso no topo do nível. Essa sucessão raramente é completa, pois os ciclos estão freqüentemente truncados.

Embora as sucessōes obsenvadas sejam similares, ocorrem variaçöes locais. Assim, na estrada Arcos-Pains (Perfil 5) é freqüente a presença de niveis conglomeráticos com gradação normal que passam a calcarenitos com laminação plano-paralela; raramente se observa o nivel com laminaçōes cruzadas por onda (Prancha 18, foto 1). Para o topo da seção ocorrem camadas espessas (decimétricas a métricas) de conglomerados caóticos, não organizados, com intraclastos placóides, alguns encurvados, decimétricos a centimétricos, subarredondados a arredondados. 


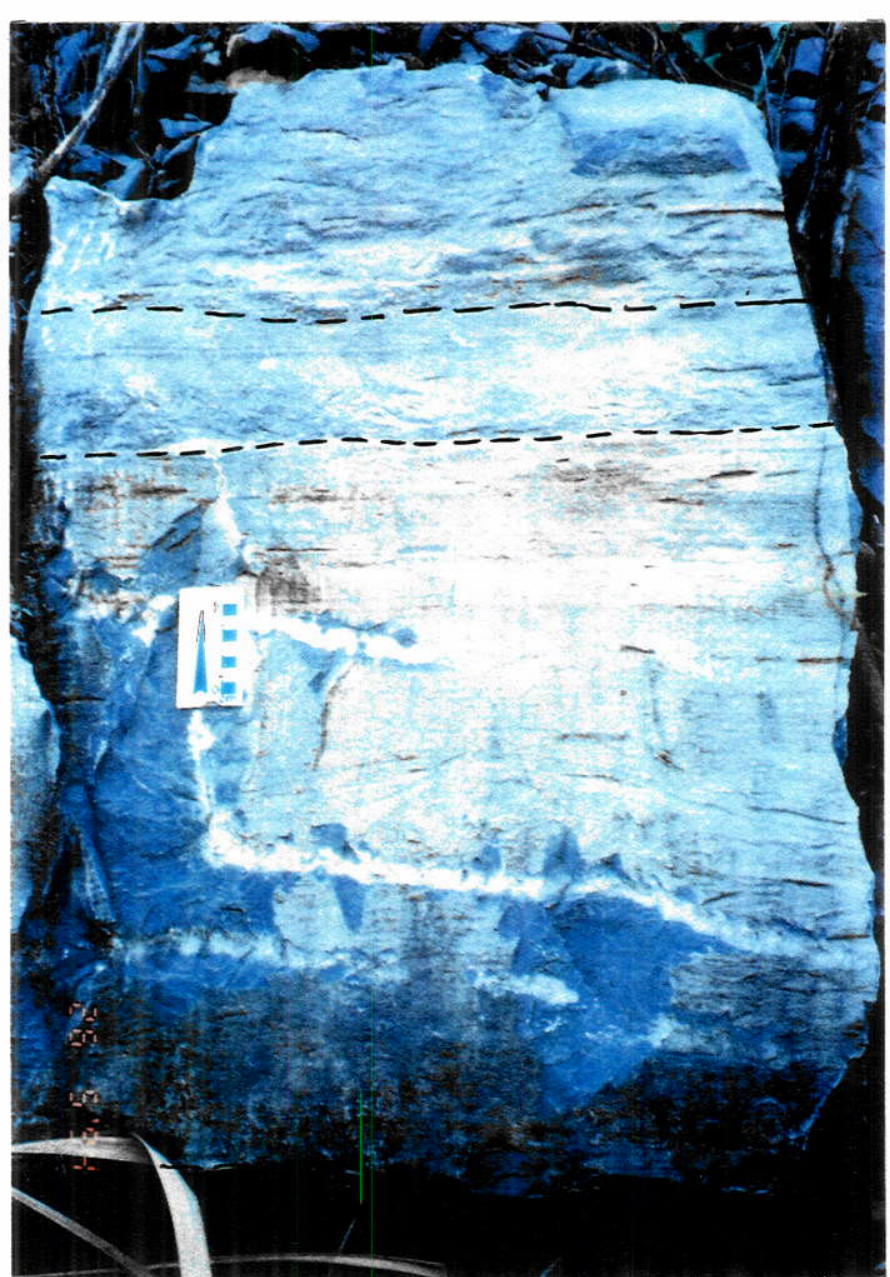

Foto 1 - Afloramento das Fácies CaCrD no Perfil 5, na estrada Arcos - Pains, onde calcirruditos apresentam gradação normal a calcarenitos com laminação planoparalela, e são truncados por nova sucessão que apresenta calcirruditos na base.

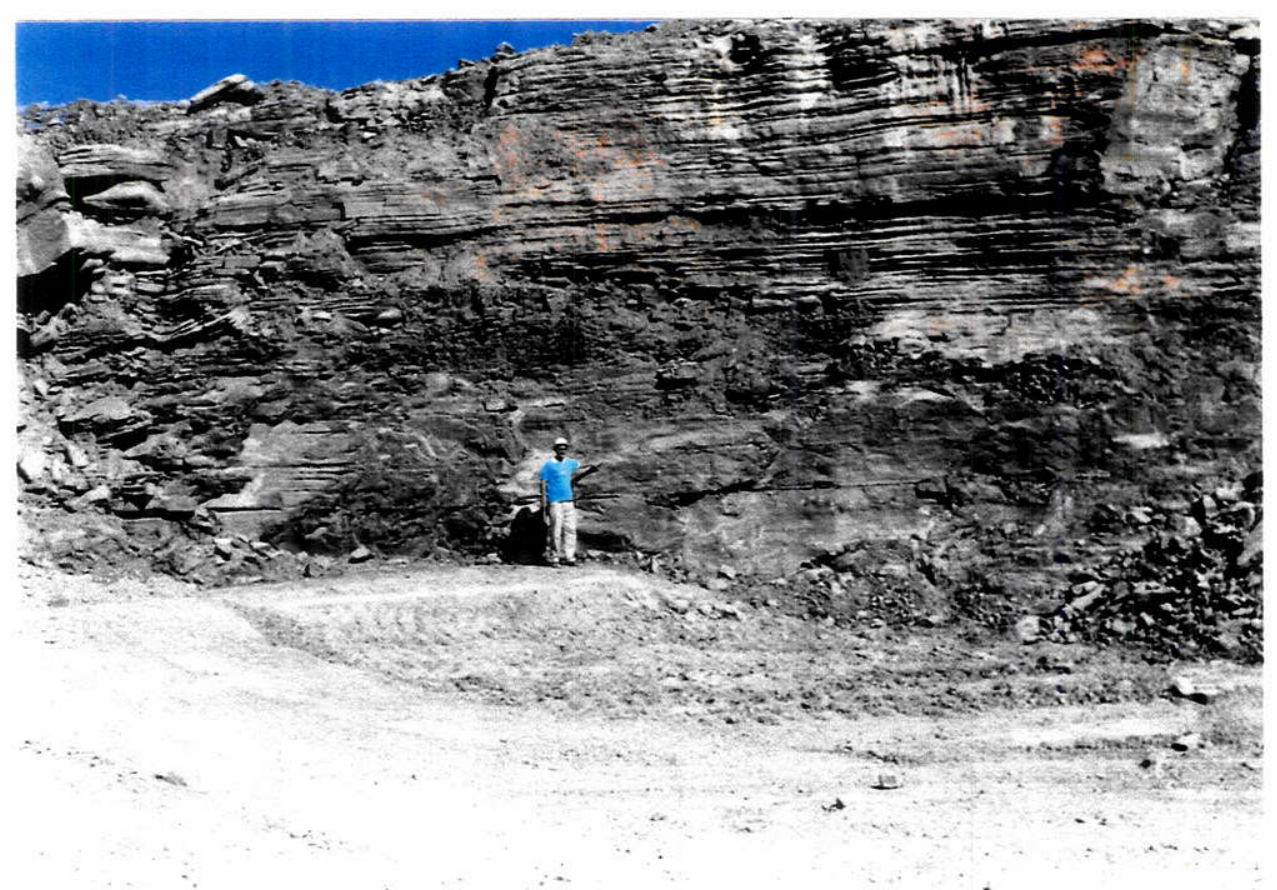

Foto 2 - Vista geral da Fácies CaCrD na Mina da Bocaina, Perfil 1. Observar amalgamação dos níveis. Cota 730 metros. 
Na Mina da Bocaina é possivel observar a amalgamação dos niveis, que são frequentemente truncados por marcas onduladas (Prancha 18, foto 2). De modo geral os ciclos iniciam-se com calcarenitos de granulação grossa ou conglomerados na fração grânulos com estratificação cruzada por ondas, e gradam para calcarenitos mais finos com laminação cruzada por onda, e eventualmente marcas onduladas centimétricas; no topo do ciclo pode ocorrer calcissiltito com laminação plano-paralela a ondulada. Não se observam para o topo da fácies os espessos niveis conglomeráticos que ocorrem na estrada ArcosPains (Perfil 5), havendo gradação para os calcarenitos da Fácies $\mathrm{CaDz}$ através de níveis de calcissiltitos com laminações cruzadas por onda e plano-paralelas, truncadas por marcas onduladas.

Os calcarenitos são predominantemente packstones mal selecionados, compostos por pelóides e bioclastos de calcário microbiano críptico; subordinadamente, ocorrem wackestones.

Por toda a fácies, mas em especial nos horizontes de granulação mais fina, ocorrem inúmeros pelóides micríticos, ovalados ou arredondados, de granulação areia fina, que estão parcial ou totalmente neomorfizados.

\section{7 - FÁCIES CaDz: Calcarenito dolomítico com estratificação cruzada}

Os calcarenitos dolomíticos com estratificação cruzada constituem um pacote de aproximadamente sete metros de espessura na Mina da Bocaina (Perfil 1), em contato transicional com a Fácies CaCrD; na mina abandonada da COMIG (Perfil 3), transicionam com a Fácies Crf e têm cerca de seis metros de espessura.

Na Mina da Bocaina (Perfil 1), a fácies inicia-se com o predomínio de calcarenitos dolomíticos sobre os sedimentos da Fácies CaCrD. No Perfil 3, recobre os calcilutitos com niveis brechóides da Fácies Crf. Como estruturas sedimentares, apresenta, na base, estratificaçäo cruzada por ondas e marcas onduladas decimétricas a métricas. Pequenas lentes de lama carbonática ocorrem na parte basal da fácies (Prancha 19).

Para o topo predominam estratificações cruzadas planares, com sets tabulares, centimétricos a decimétricos. A porção superior da fácies apresenta estratificação cruzada por onda, de baixo ângulo, finamente laminada, e ondulaçōes suaves, que em perfil, apresentam comprimento de onda de cerca de 1 metro.

Os principais tipos texturais presentes nos perfis 1 e 3 são packstones e grainstones; subordinadamente ocorrem wackestones (Prancha 20). Calcissiltitos dolomíticos ocorrem muito subordinadamente na porção basal da fácies. 


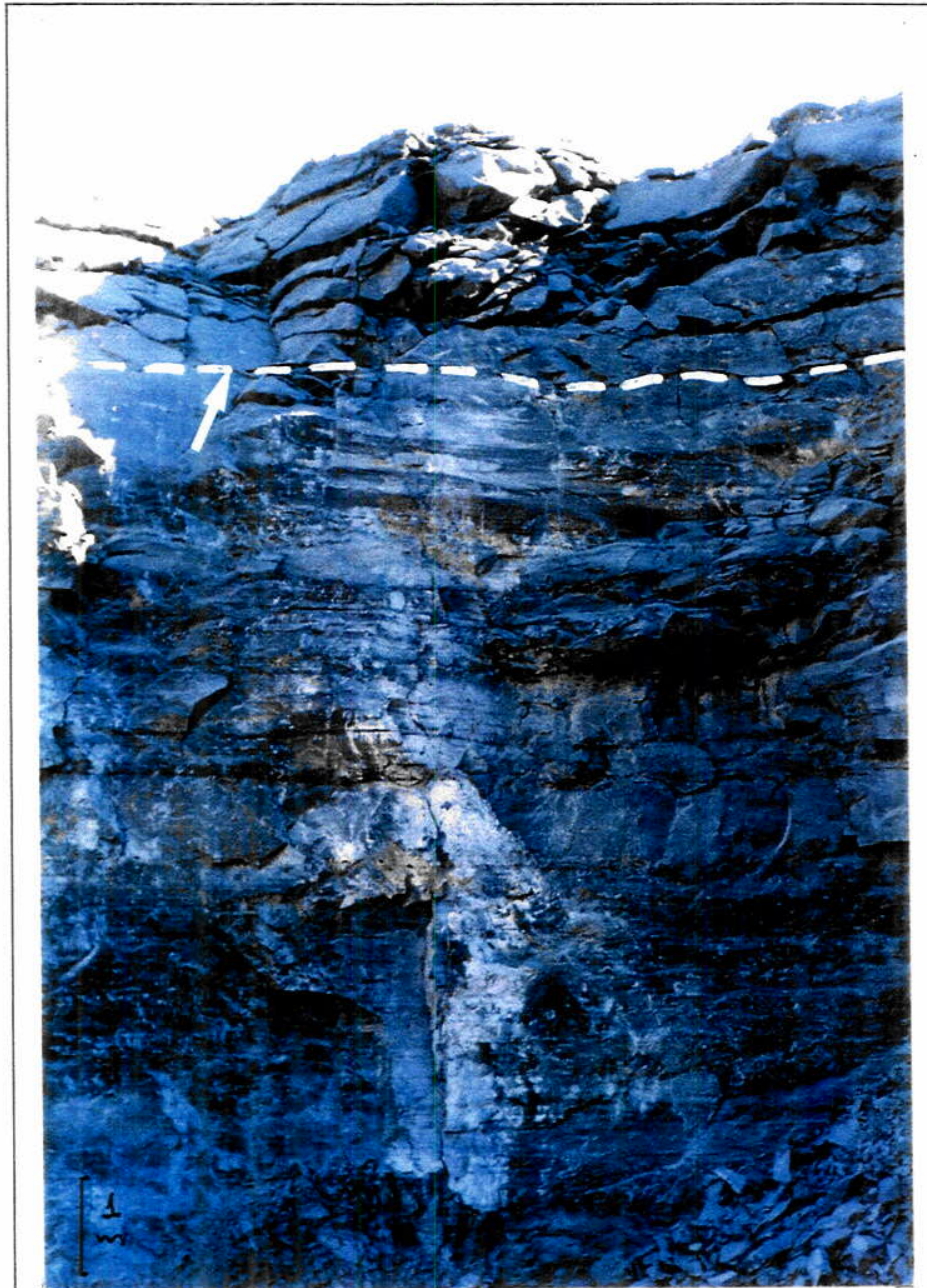

Foto 1 - Vista geral da Fácies $\mathrm{CaDz}$ na Mina da Bocaina. Observar limite inferior do dolomito calcítico e seu padrão de quebramento em lascas.

Foto 2 - Foto de detalhes da base da Fácies $\mathrm{CaDz}$

Foto 3 - Estratificação cruzada planar observada abaixo do nível de dolomito calcítico, na Mina da Bocaina, Perfil 1

PRANCHA 19
Foto 2

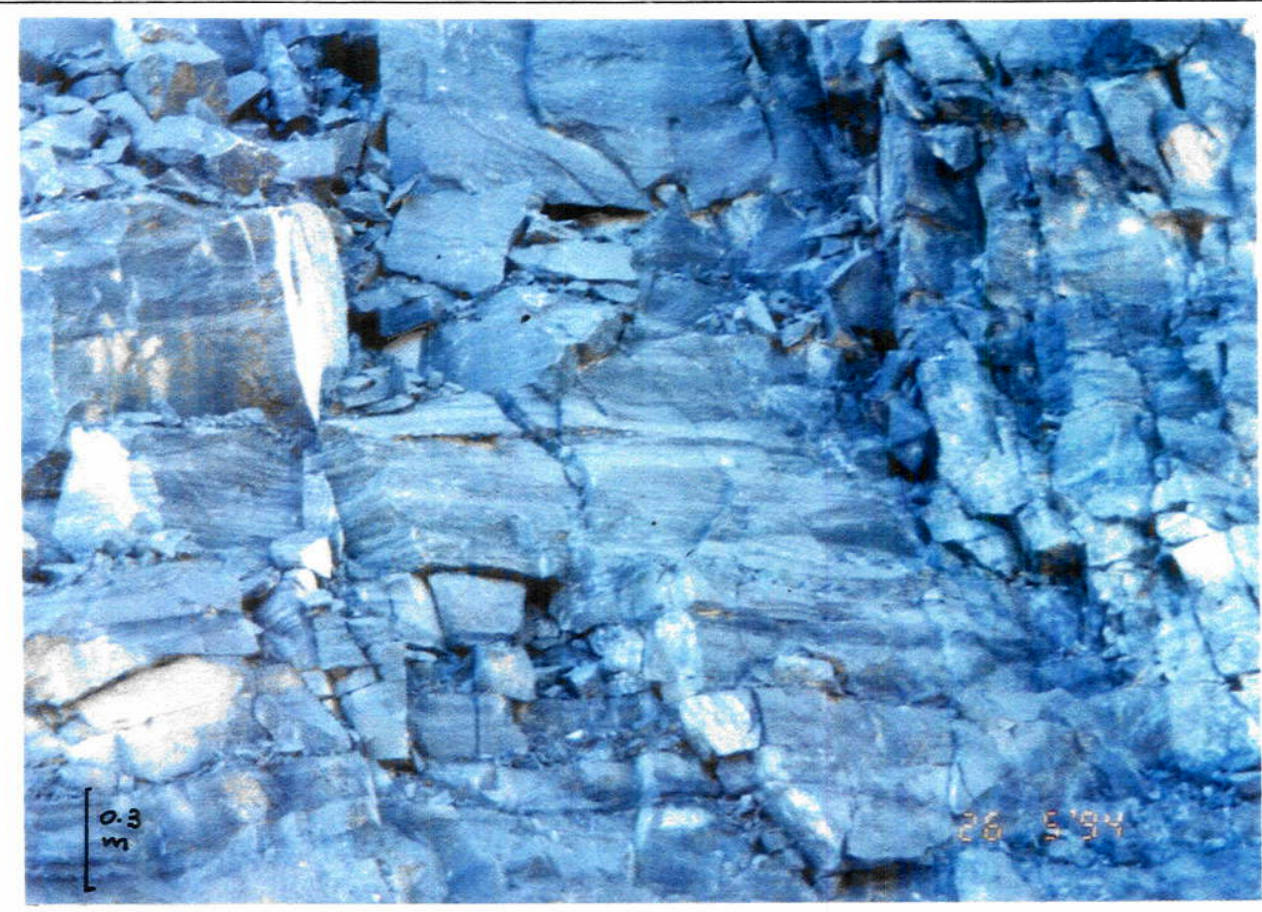

Foto 3

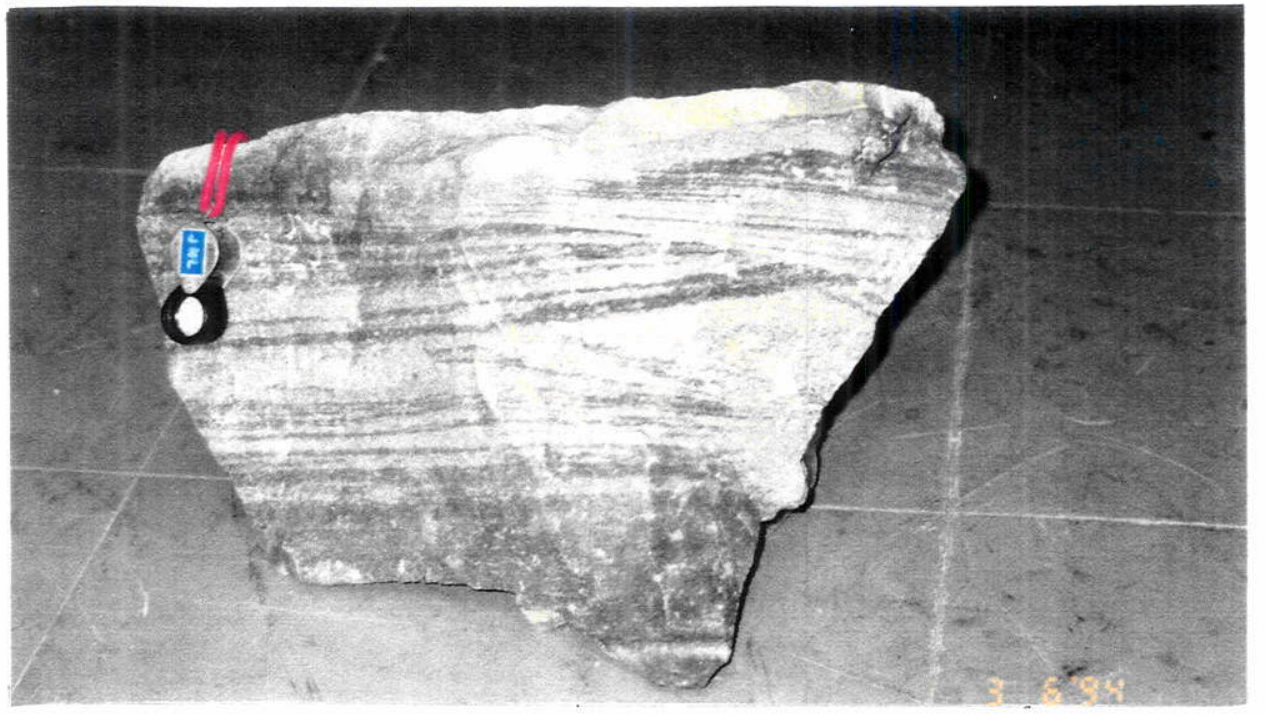




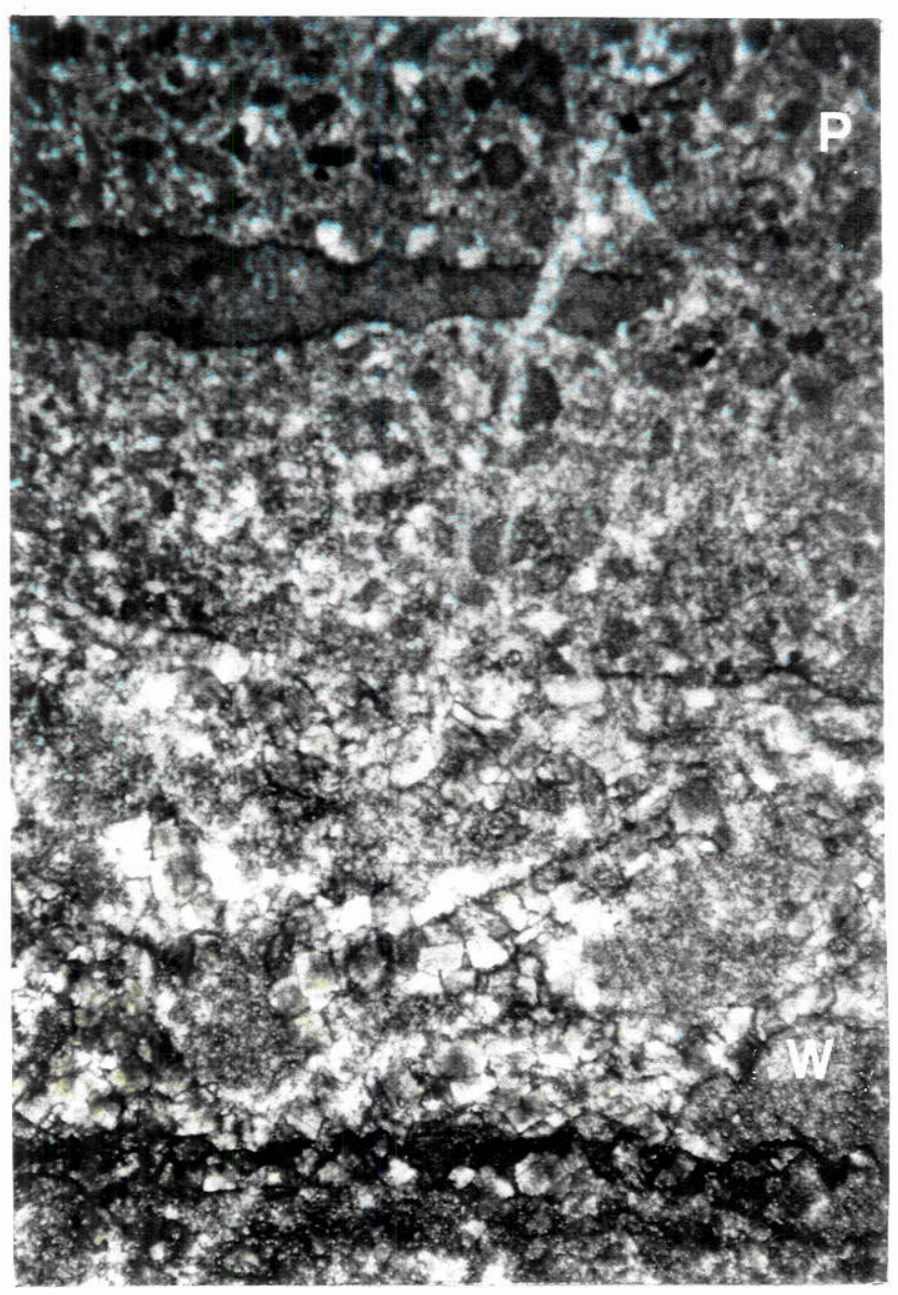

Foto 1 - Fotomicrografia de calcarenito dolomítico da Fácies $\mathrm{CaDz}$; observar a diferença de dolomitização entre packstone e wackestone, na Mina da Bocaina, Perfil 1. X.N. 30x.

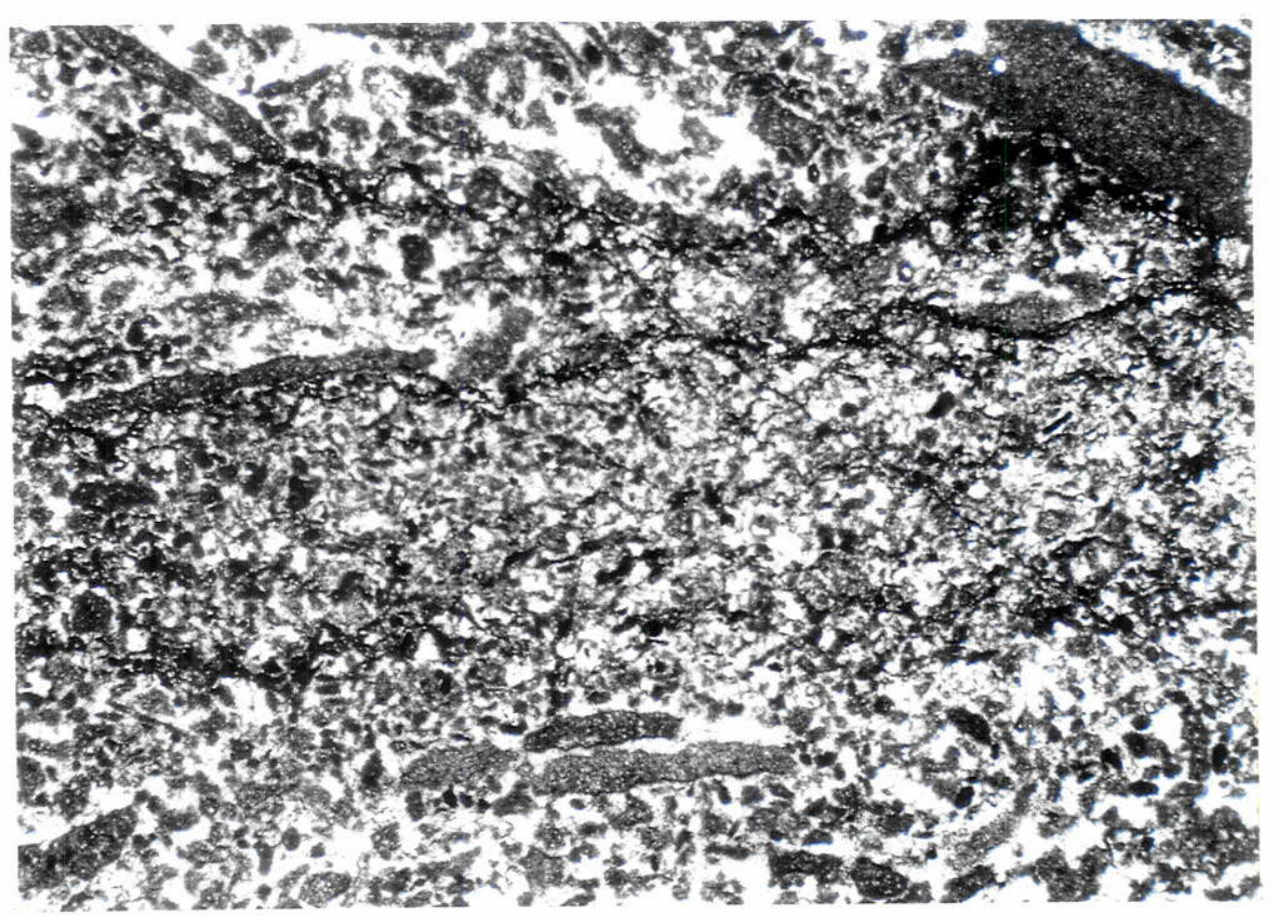

Foto 2 - Fotomicrografia de grainstone com estratificação cruzada, composto por pelóides, intraclastos lamelares e ainda bioclastos de calcário microbiano críptico da Fácies CaDz. Mina da Bocaina, Perfil 1. L.N. 10x 
Os calcarenitos dolomíticos são de granulação areia fina ou média e frequentemente contém grânulos (até $5 \%$ ). Os grãos aloquimicos são intraclastos micríticos e bioclastos de calcário microbiano críptico, que podem ser irregulares, placóides ou ovalados quanto à forma, subangulares ou arredondados.

Os wackestones apresentam pelóides bem arredondados de granulação areia fina ou intraclastos placóides com dimensões de areia grossa e grânulos. Apresentam evidências de compactação com estilólitos em rede, o que não se observa nos grainstones e packstones adjacentes Mais raramente observa-se calcilutitos fortemente compactados e dolomitizados.

Os calcissiltitos podem ser maciços ou apresentar laminação plano-paralela a cruzada de baixo ângulo.

A dolomitização não afeta de modo homogêneo os diferentes tipos texturais. Os niveis de grainstones adjacentes a wackestones praticamente não são afetados pela dolomitização, ao passo que os packstones e wackestones apresentam de $20 \%$ a $40 \%$ de dolomita. O calcissiltito é pouco dolomitizado (cerca de 10\%).

5. 8 - FÁCIES CaDa: Calcarenito dolomítico com estratificação cruzada acanalada

Ocorre no Perfil 4, na mina em atividade da COMIG, têm cerca de sete metros de espessura; o contato com a litologia subjacente não é observado. Embora o calcarenito dolomítico descrito na fácies $\mathrm{CaDz}$ apresente semelhanças com o da Fácies $\mathrm{CaDa}$, observa-se que exibem algumas diferenças entre si, em especial no que se refere às estruturas sedimentares.

Na mina em exploração da COMIG, o calcarenito dolomítico constitui um pacote com cerca de 3 metros de espessura observável; estratificação cruzada truncada por ondas (Prancha 21, foto 1) e estratificação cruzada acanalada de pequeno porte são as principais estruturas sedimentares observadas.

$\mathrm{Na}$ base do afloramento, as estratificações cruzadas por onda são finamente laminadas, e apresentam truncamentos por ondulaçōes de baixa amplitude; em direção ao topo da fácies, as ondulaçöes apresentam comprimento de onda progressivamente menor e são cortadas esporadicamente por pequenos canais (scours) preenchidos por cruzadas acanaladas (centimétricas).

Observa-se ainda, intercalados nos calcarenitos, delgados níveis de conglomerados com grânulos que apresentam gradação normal e superfície basal erosiva. 


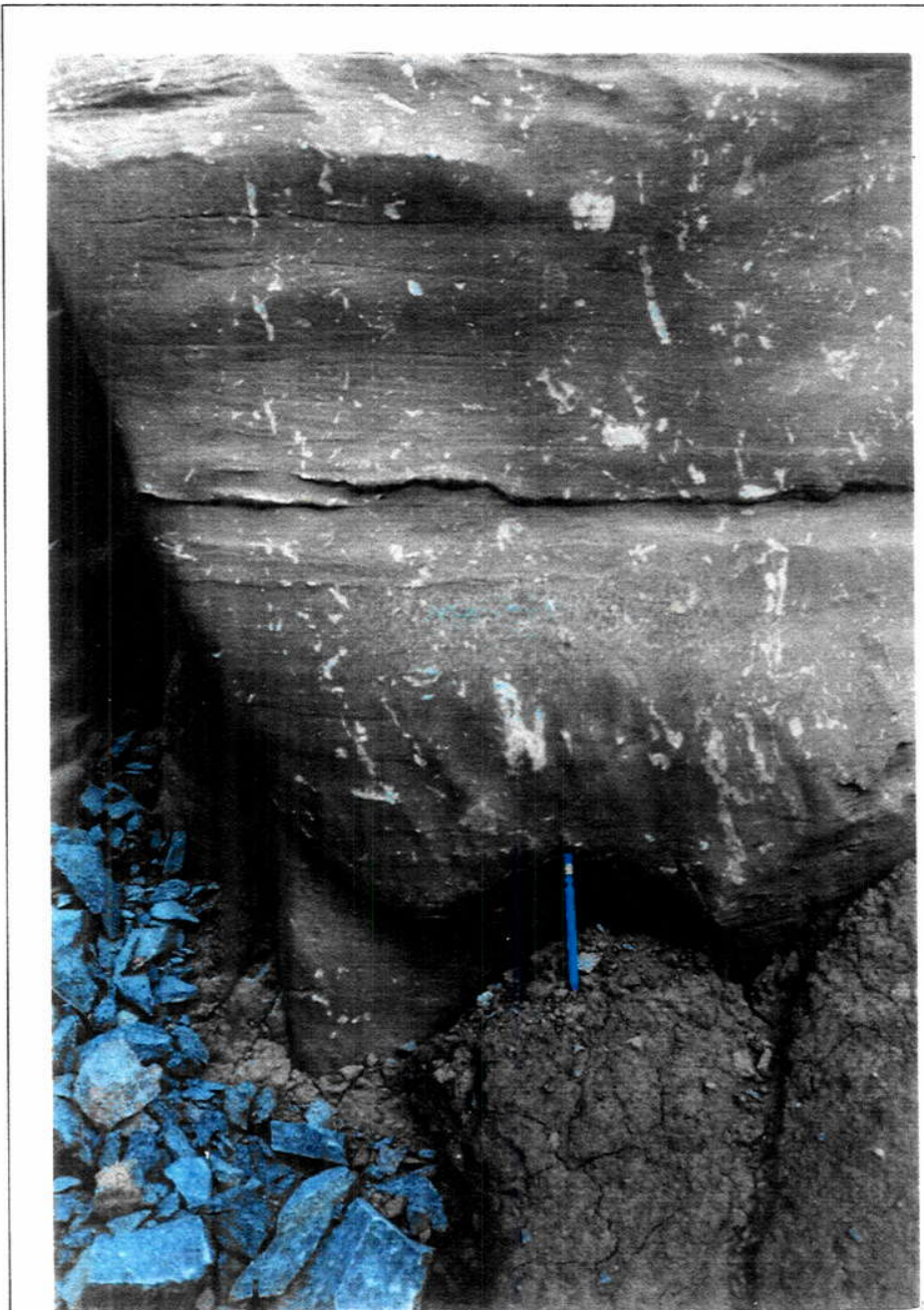

Foto 1 - Estratificações cruzadas truncadas por ondas, em afloramentos da Fácies CaDa. Perfil 4, na mina em atividade da COMIG.

Foto 2 - Calcarenito dolomítico da Fácies CaDa, no Perfil 4. X.N. $40 x$.

Foto 3 - Calcarenito dolomítico com aloquímicos bem arredondados. Fácies $\mathrm{CaDa}$, na mina em atividade da COMIG. X.N. 30x.
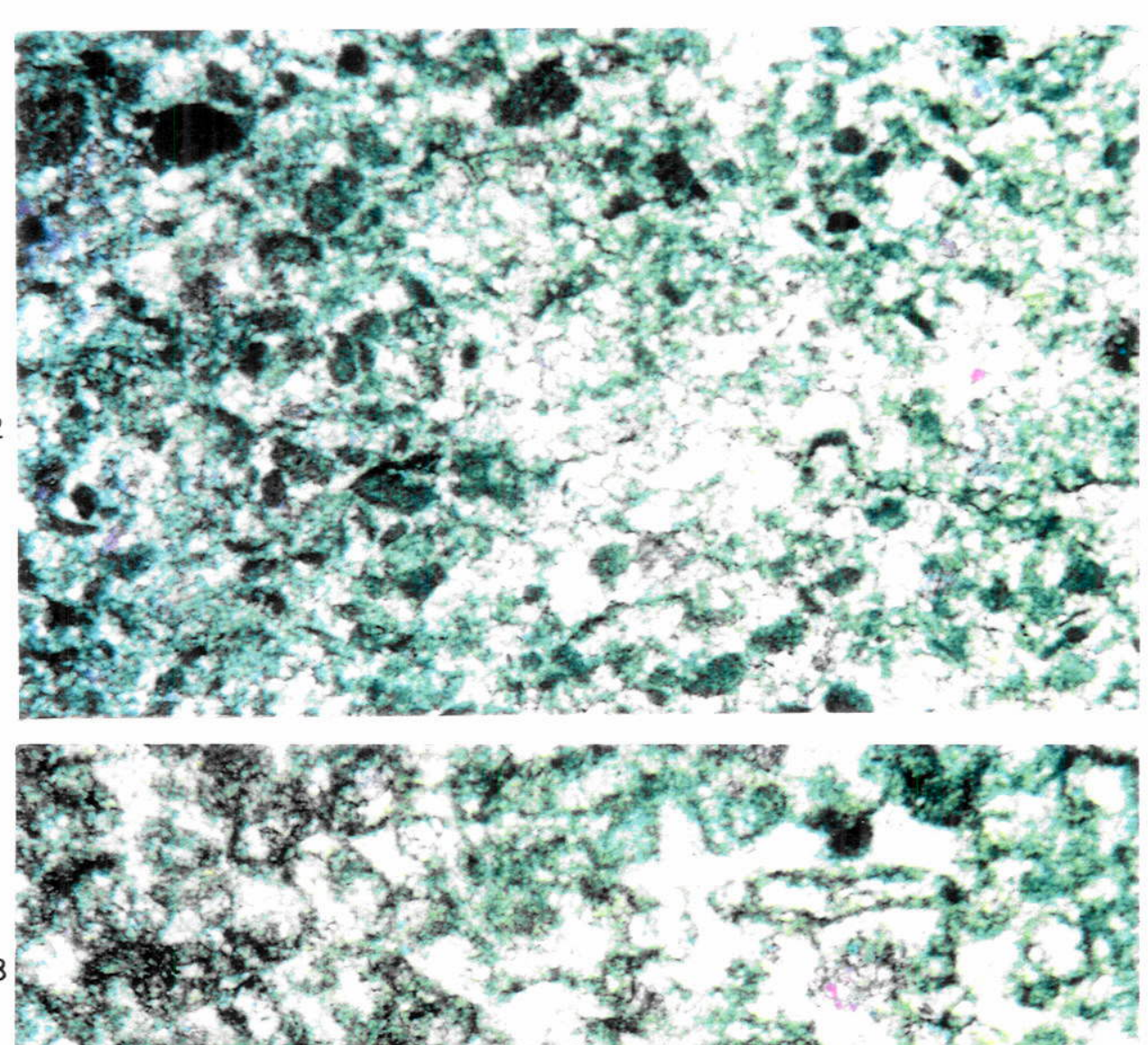

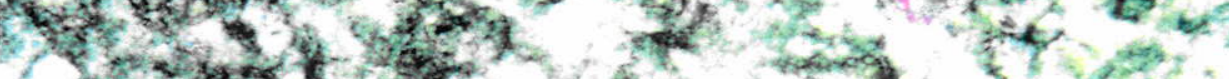
2.

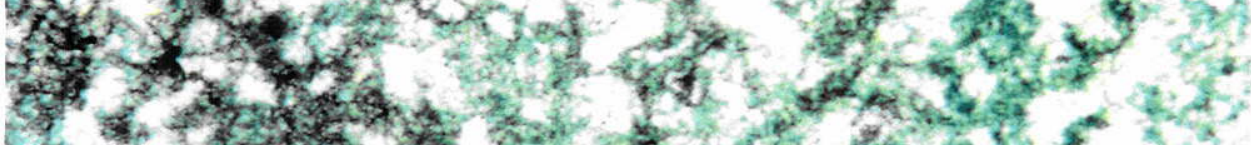

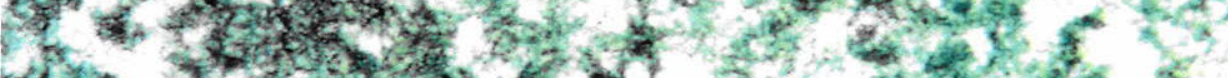

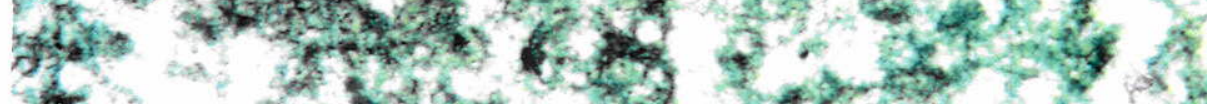

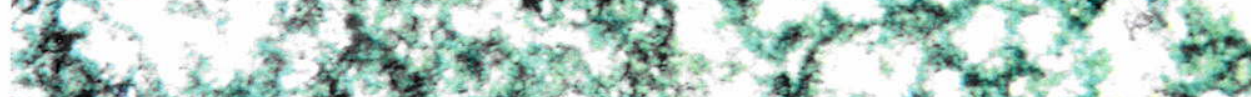

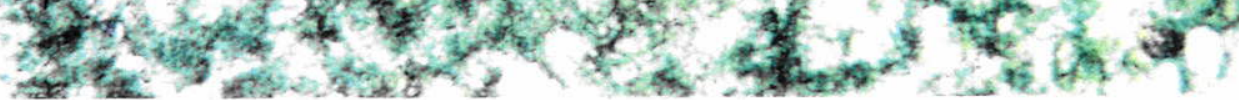


Petrograficamente, o calcarenito dolomítico é constituído por grainstones a packstones de arcabouço aberto, sem evidências de compactação. São compostos por bioclastos e intraclastos micríticos, de granulação areia fina a média, e apresentam vestígios de franja isópaca, originalmente aragonítica que foi posteriormente dolomitizada. Freqüentemente os qloquímicos são mal selecionados, tendo cerca de $5 \%$ dos grãos nas fraçöes areia grossa e grânulos, podendo atingir $10 \%$ nos grainstones que compõem as cruzadas acanaladas. Os grãos são subarredondados a arredondados, ovalados a esféricos, placóides ou irregulares (Prancha 21, foto 2).

Ainda em lâmina delgada, foi observado um nivel de grainstone composto por aloquímicos extremamente bem arredondados, ovalados, irregulares ou alongados, de contorno micrítico nítido, mas sem estrutura interna preservada; os grãos são mal selecionados, com mistura de grãos areia fina a média e grossa e mostram semelhanças com microfitólitos (Prancha 21, foto 3).

Não se observa, em todo o pacote, a presença de sedimentos finos.

Freqüentemente, na parte superior da fácies, ocorre dissolução parcial ou total de grãos, com posterior preenchimento por calcita espática.

Em geral os calcarenitos apresentam cerca de $20 \%$ a $30 \%$ de dolomita, mas nos niveis basais essa porcentagem não ultrapassa $10 \%$.

Todo o pacote de calcarenito dolomítico é truncado, próximo ao topo da fácies, por uma superficie irregular que representa a base do dolomito calcítico (Fácies Dcc). Os calcarenitos situados acima dessa superfície estão fortemente dolomitizados, sem preservação da textura original da rocha (Prancha 22).

\section{9 - FÁCIES Dcc: Dolomito calcítico}

Frequentemente ocupa o topo das várias elevações da área, e exibe feições cársticas, geralmente em lapiez. Apresenta limites basal e de topo nítidos e irregulares (Prancha 22, foto 1), tem espessura variável entre três e cinco metros, é de cor cinza bem mais claro que as litologias vizinhas, e quebra em lascas, padrão facilmente identificável no campo. Corresponde ao dolomito sacaróide de Madalosso \& Veronese (1978).

Na Mina da Bocaina (Perfil 1), embora em afloramento se identifique o nivel de dolomito calcítico, quase sempre é possível reconhecer petrograficamente a textura original da rocha (Prancha 4, foto 4) embora afetada em maior ou menor grau pela dolomitização. 


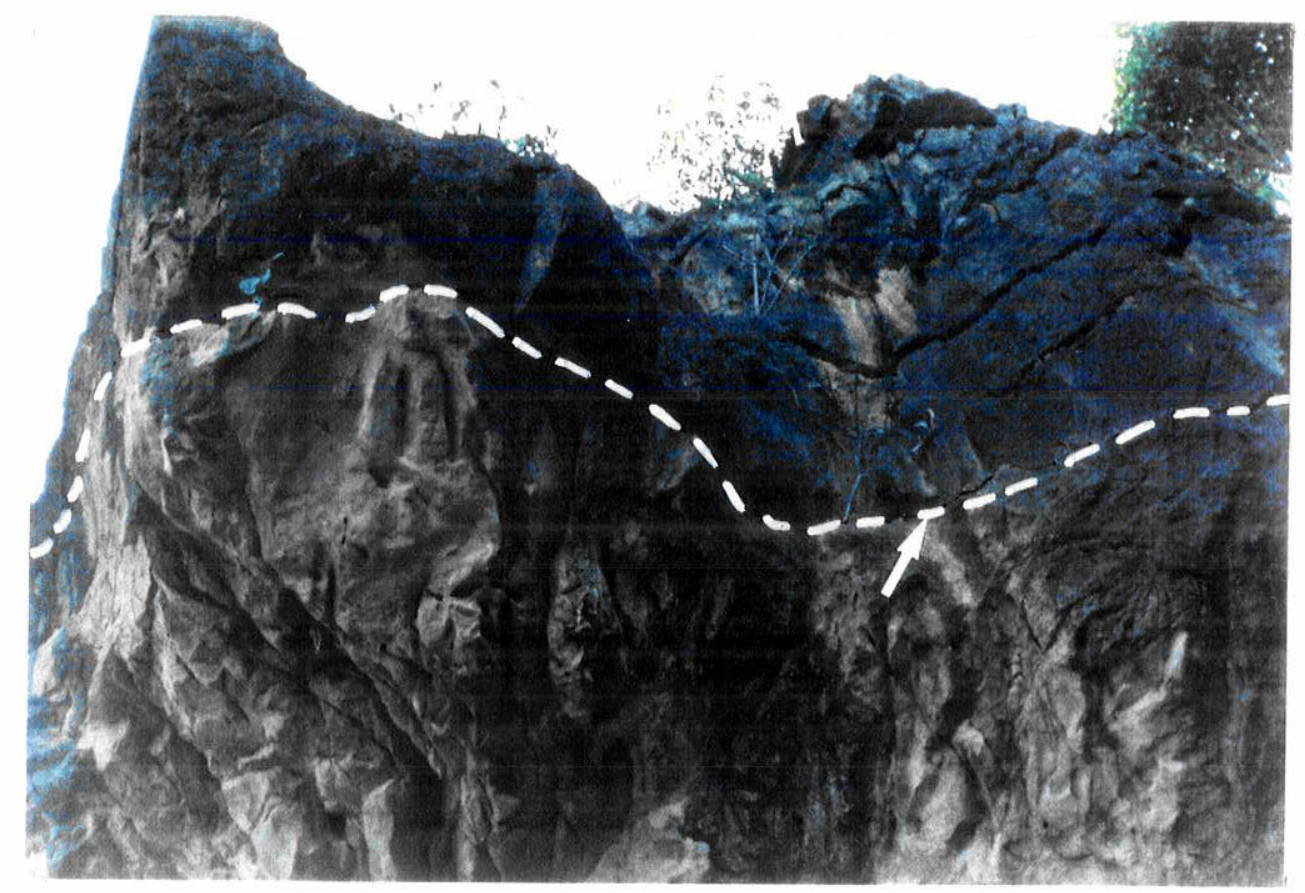

Foto 1 - Vista geral do limite superior do dolomito calcítico (Fácies Dcc), em contato com dolomitos estromatolíticos no Perfil 4, na mina em atividade da COMIG.

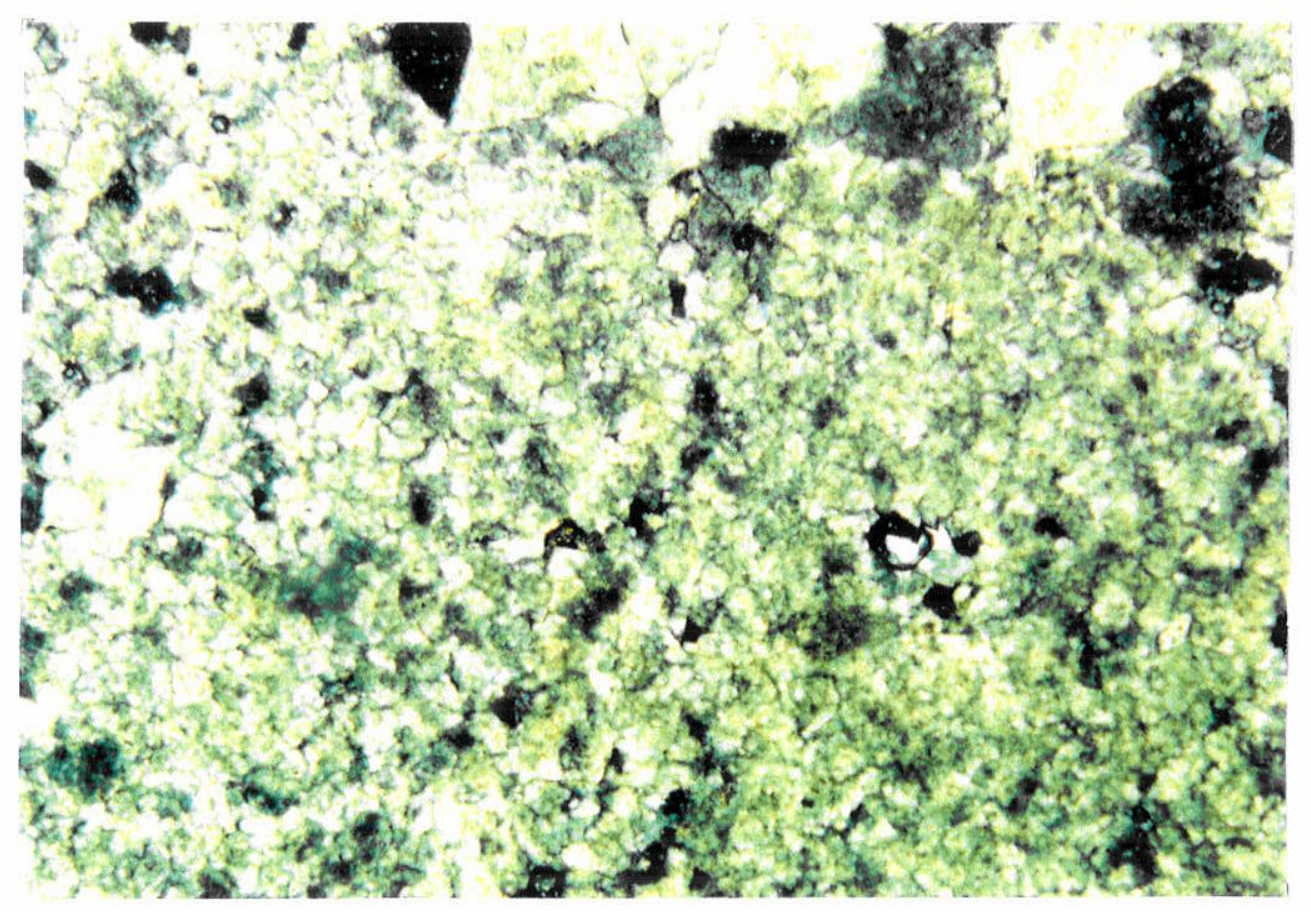

Foto 2 - Fotomicrografia do dolomito calcítico (Fácies Dcc), onde se observa apenas um dolomito cristalino. Perfil 4, na mina em atividade da COMIG. X.N. $65 x$ 
Nos perfis 3 e 4 a dolomitizaçäo é mais intensa, e em lâmina delgada observa-se apenas um dolomito cristalino (Prancha 22, foto 2), com raros vestígios de aloquímicos ou de laminaçōes. Eventualmente observa-se grãos bem arredondados, ovalados, de contorno difuso, com vestígios de envelopes micríticos concêntricos; alguns grãos parecem ser polinucleados e são de granulação areia muito grossa. Próximo ao topo do pacote dolomítico, um nivel com cerca de 1 metro de espessura parece conter estromatólitos estratiformes com formas colunares associadas.

5.10 - FÁCIES DEd: Dolomito estromatolítico com elementos dômicos de pequeno porte

Ocorre apenas na Mina da Bocaina, onde constitui um bioherma de aspecto lenticular, com espessura máxima de três metros e cerca de cinco metros de extensão; é composto predominantemente por pequenos estromatólitos dômicos (Prancha 23, foto 1), sobrepostos aos calcarenitos dolomíticos da Fácies $\mathrm{CaDz}$. Na base do bioherma, observase estromatólitos estratiformes e pequenos cumulados assimétricos assentados sobre delgados niveis micríticos, ou niveis de intraclastos micríticos com raros bioclastos semelhantes a algal chips (Prancha 5, foto 5).

Os estromatólitos dômicos freqüentemente são contíguos, mas podem apresentar espaçamento centimétrico. Possuem diâmetro subcircular de até 50 centímetros e altura média de 30 centímetros. São ligeiramente assimétricos, e em alguns estromatólitos observa-se a presença de parede externa praticamente vertical, o que sugere que possuiam relevo, tendo se desenvolvido livres dos sedimentos adjacentes. Apresentam laminações convexas, com alternância de lâminas claras e escuras, lisas, sem ondulações e grau de herança médio a alto. Podem ocorrer descontinuidades, em especial nas lâminas mais externas. Não foram observadas feições de ressecação.

Os estromatólitos estão fortemente dolomitizados, mas em lâmina delgada ainda são visíveis delgados niveis micríticos, contínuos, alternados com niveis espessos, de cor mais clara que contém vestígios de aloquímicos. Exibem laminação fenestral e evidências de terem sofrido dissolução parcial, com abertura de cavidades, pois apresentam fragmentos de suas paredes cimentados por calcita espática. 


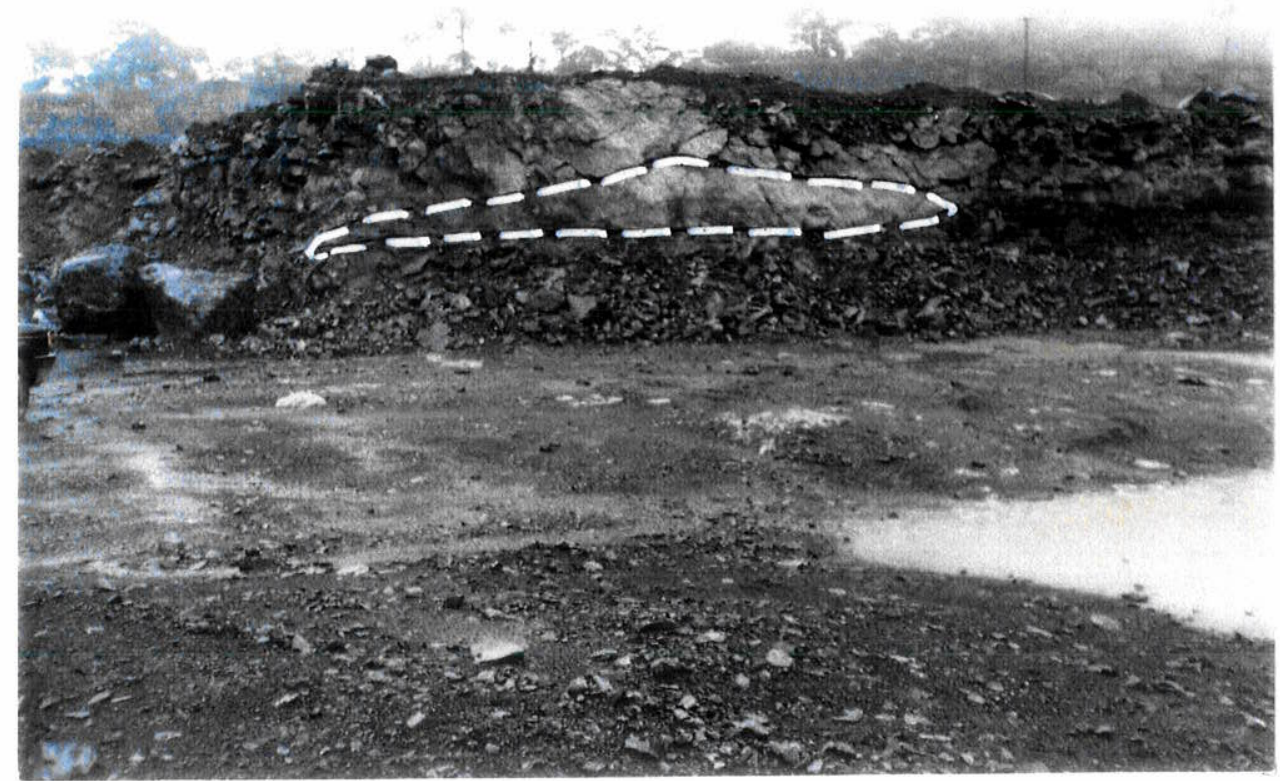

Foto 1 - Vista geral do bioherma estromatolítico da Fácies DEd. Mina da Bocaina.

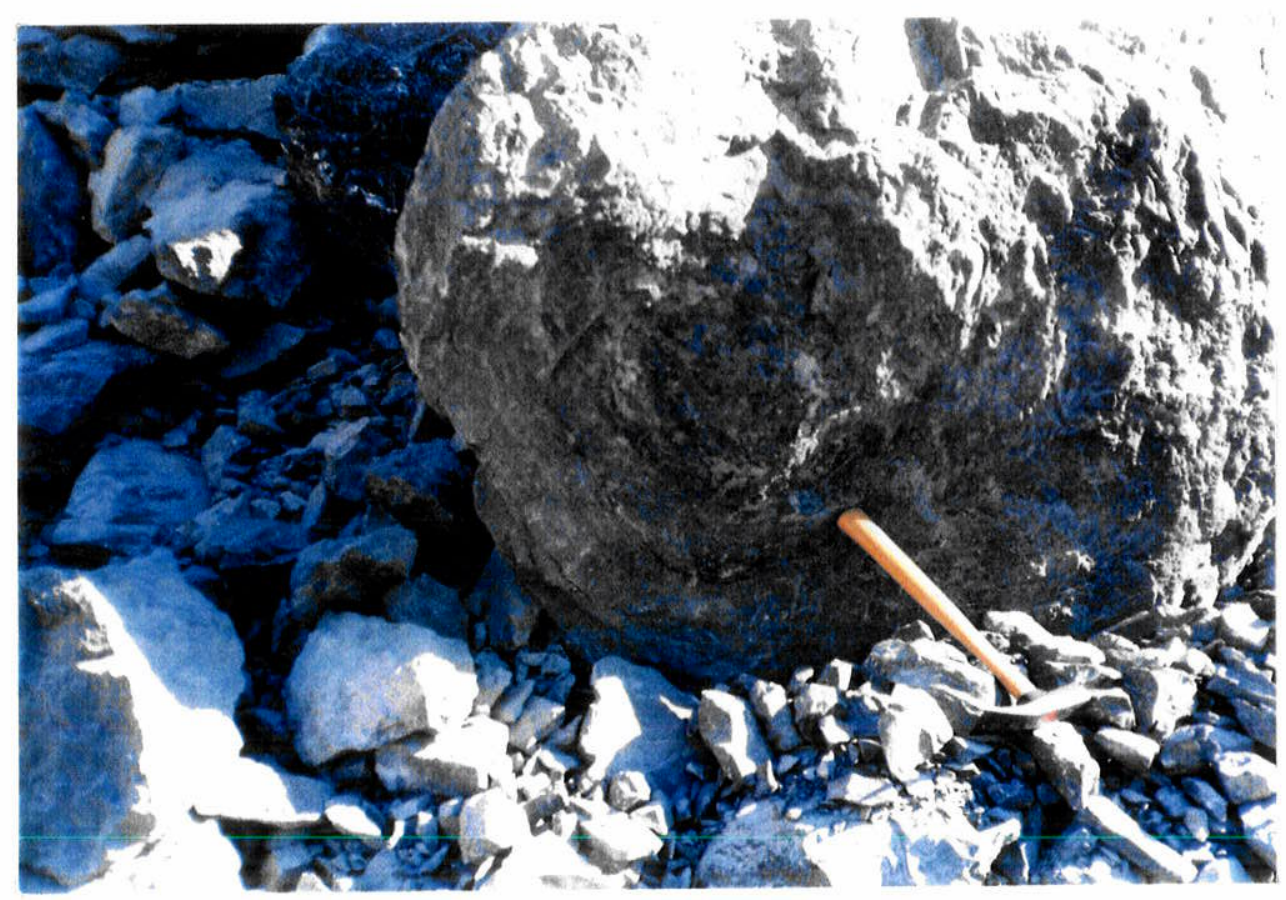

Foto 2 - Bloco caído de estromatólito dômico (Fácies DEdc); ocorre associado a dolarenito ooidal. Mina da Bocaina, Perfil 1. 
5.11 - FÁCIES DEdc: Dolomito estromatolítico com formas dômicas e colunares associado a dolarenito ooidal

Esta fácies foi registrada apenas na Mina da Bocaina, e na maior parte das vezes, os estromatólitos foram observados em blocos soltos (Prancha 23, foto 2 e Prancha 24).

Em afloramento observou-se estromatólitos dômicos, de cerca de um metro de altura, em contato lateral com dolarenito ooidal que apresenta estratificação cruzada por onda. Em blocos rolados, observou-se que esses estromatólitos têm seção subcircular e diâmetro variando de 20 centímetros a 70 centímetros e podem ser coalescentes. Apresentam laminações convexas, lisas, que englobam intraclastos milimétricos e apresentam alguns truncamentos.

Estromatólitos aparentemente colunares, e de seção ovalada, com diâmetros variando entre 30 centímetros e 1 metro, também foram encontrados em blocos soltos. Os estromatólitos no geral são paralelos e apresentam pequeno espaçamento entre si ou são coalescentes (Prancha 24). São finamente laminados, com lâminas lisas, de 1 a 2 milimetros de espessura, e exibem descontinuidades. Apresentam relevo alto e provavelmente cresceram livres dos sedimentos adjacentes.

O dolarenito ooidal é um grainstone dolomitizado, bem selecionado, de arcabouço fechado e compactado. Os grãos são bem arredondados, de granulação grossa a muito grossa, ovalados a esféricos, e o contato entre eles é normal ou côncavo-convexo; alguns grãos sofreram dissolução e estão parcialmente silicificados (Prancha 25, foto 1). Os oóides não apresentam vestigios de capas concêntricas, e provalvemente representam oólitos que foram dolomitizados de forma não mímica, sem preservação de sua estrutura interna original.

5.12 - FÁCIES DEcP: Dolomito estromatolítico com formas colunares a pseudocolunares.

Constitui um nivel bioconstruido, estromatolítico, observado no Perfil 4, na mina em atividade da COMIG. É predominantemente composto por estromatólitos decimétricos a centimétricos, colunares a pseudocolunares.

Em lâmina delgada observa-se que pequeno estromatólito colunar apresenta grau de herança regular, com as laminaçōes exibindo várias descontinuidades (Prancha 26, foto 1). Como microestrutura, apresenta niveis lamosos contendo gräos ooidais e microfitólitos dispersos, filmes micríticos contínuos e paralelos, o que sugere terem sido construídos 


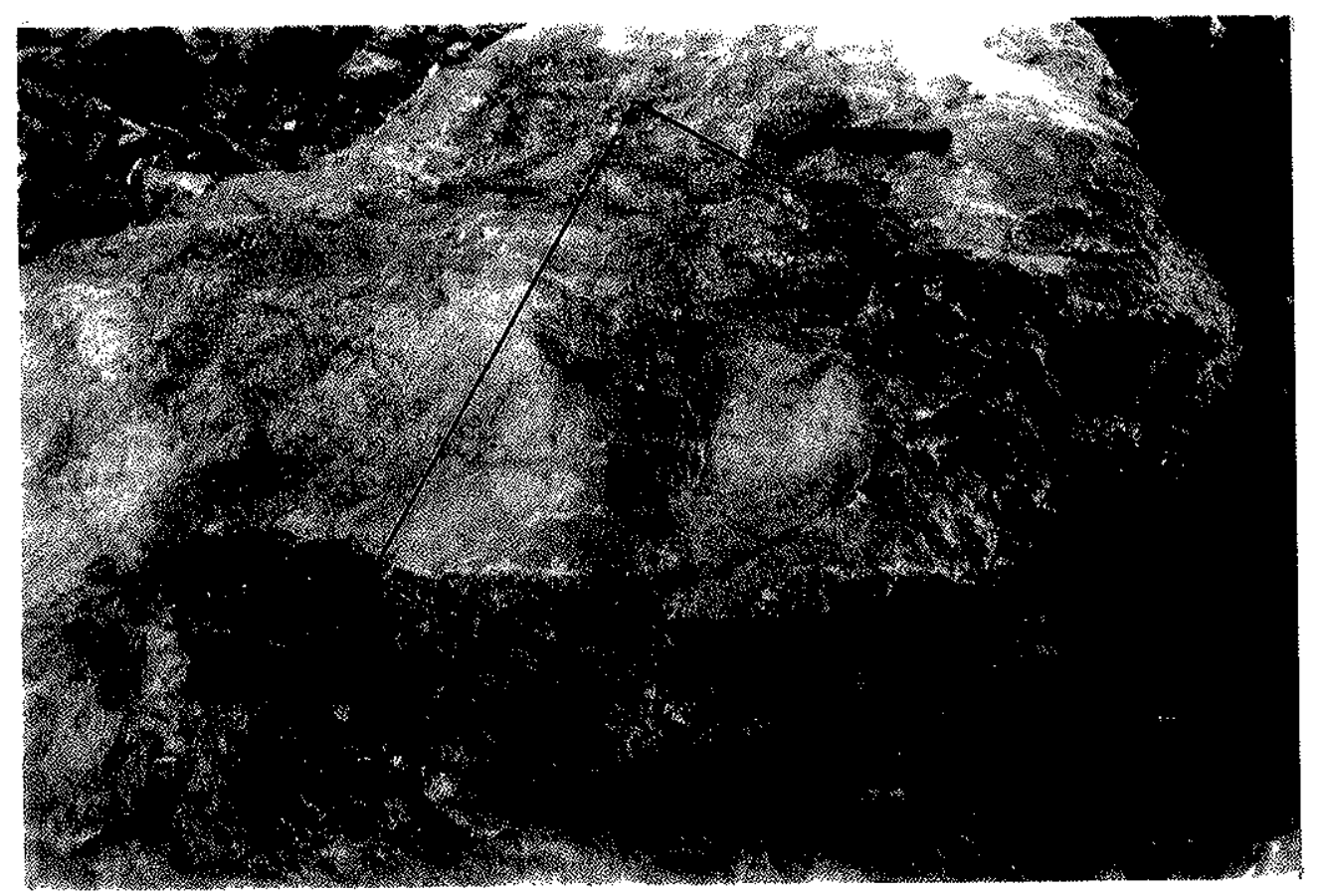

Foto 1 - Bloco caído composto por dolomito estromatolítico, com estromatólitos de grande porte (Fácies DEdc). Mina da Bocaina. Cota 755 metros.

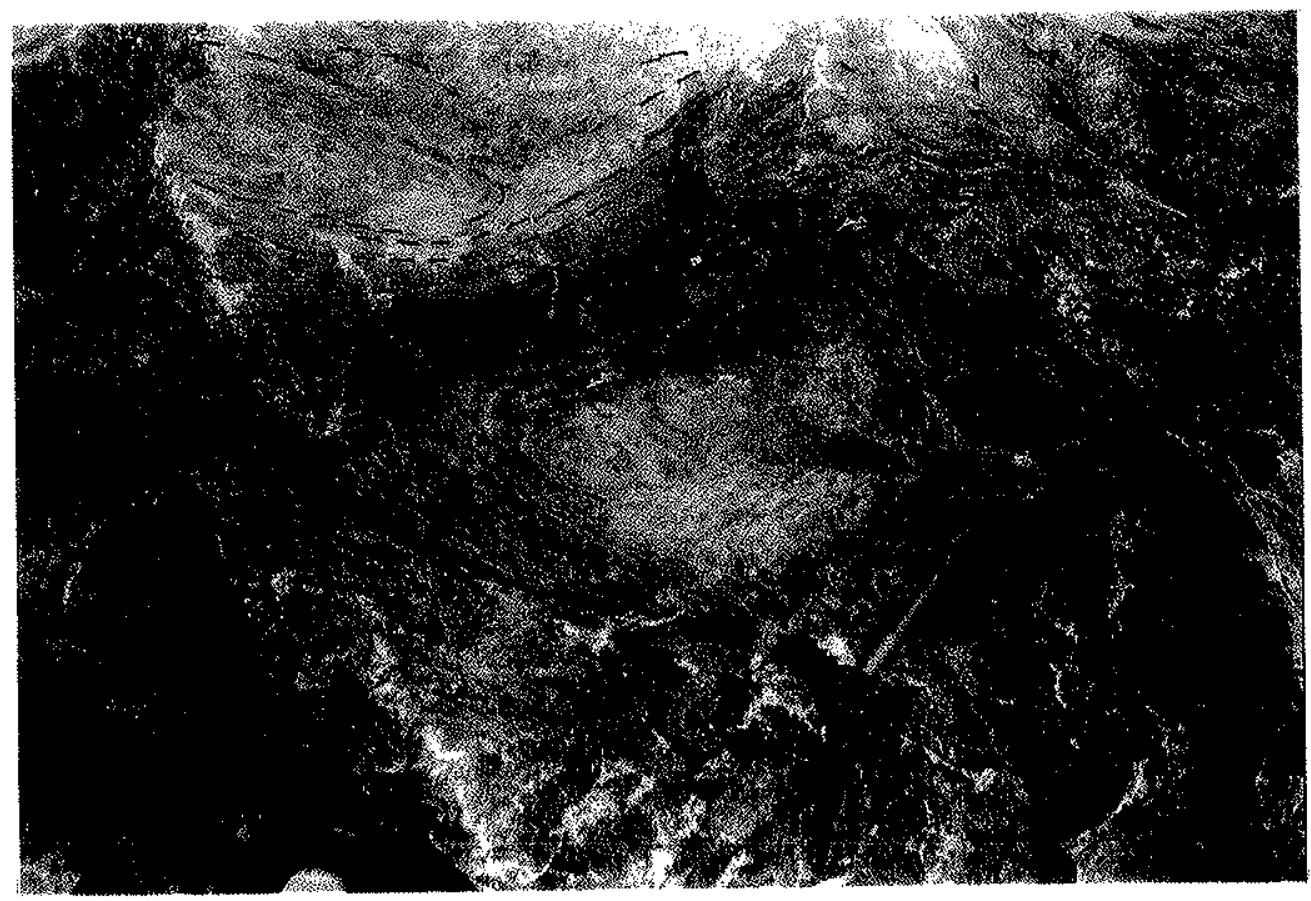

Foto 2 - Detalhe dos estromatólitos da foto 1 ; observar que os estromatólitos dispõem-se paralelamente e são coalescentes. 


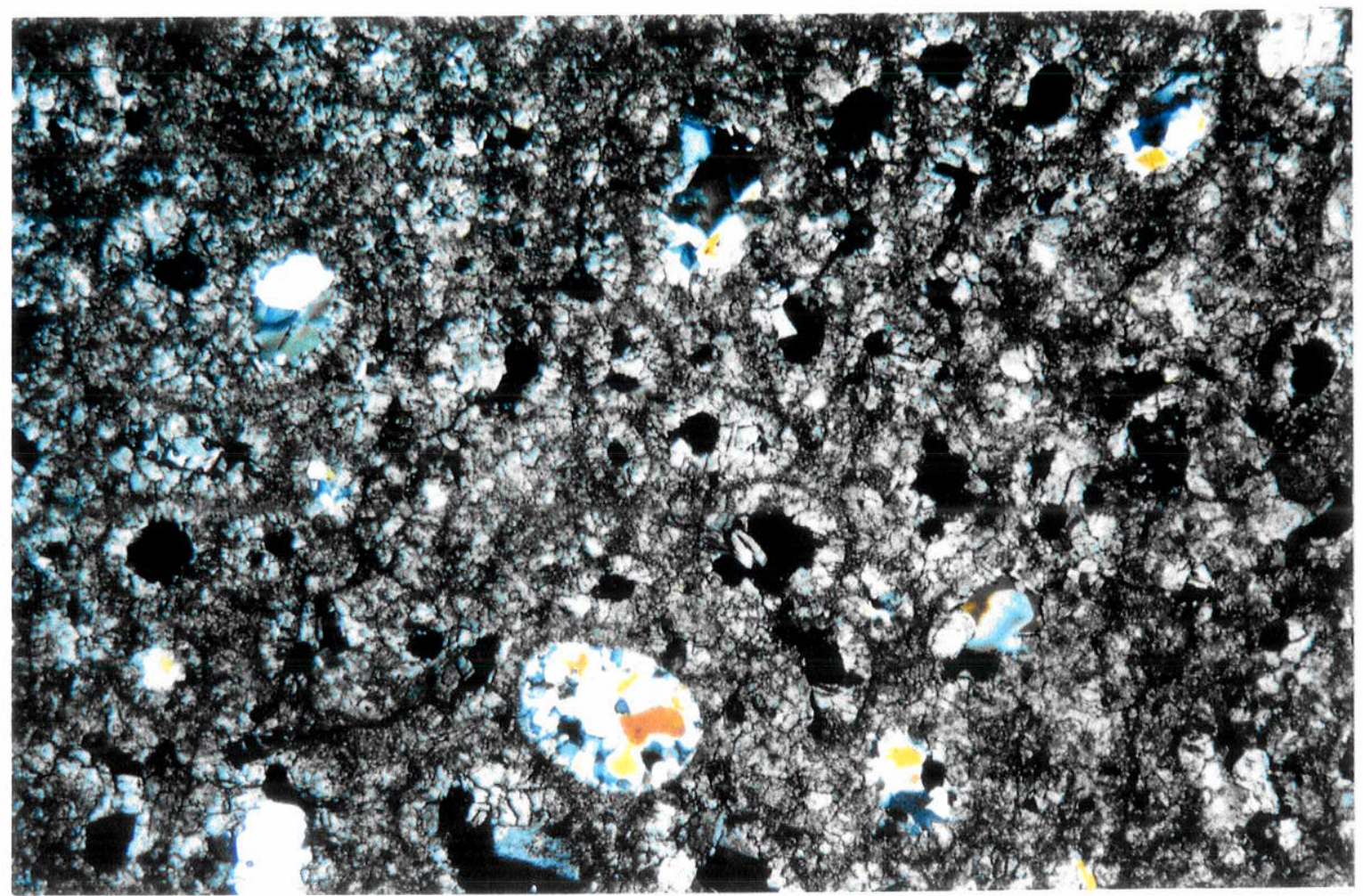

Foto 1 - Fotomicrografia do dolarenito ooidal (Fácies DEdc); a dolomitização acarreta a perda das características originais dos grãos, os quais apresentam evidências de dissolução, com preenchimento posterior das cavidades por megaquartzo. Perfil 1. Mina da Bocaina. X.N. $25 x$

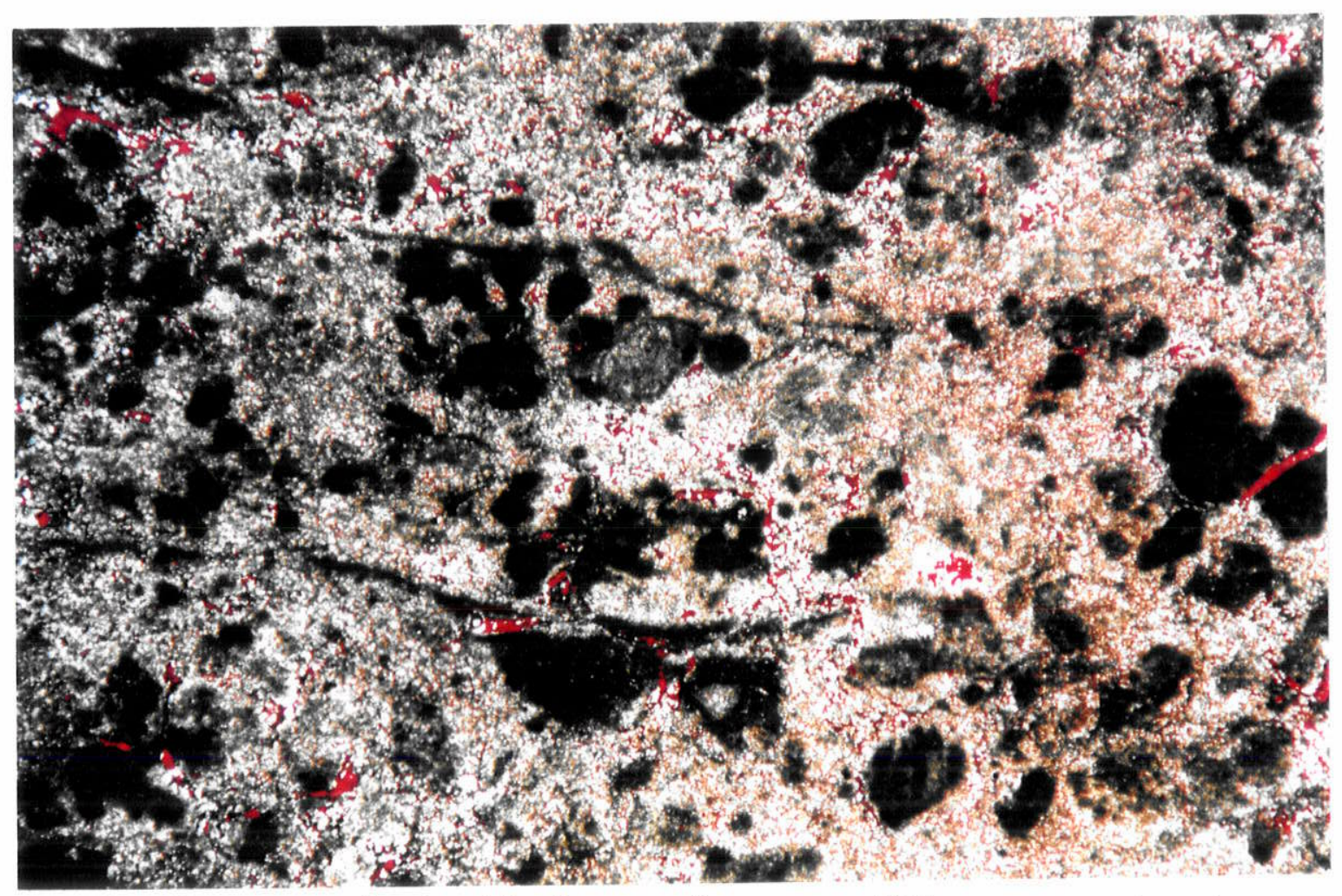

Foto 2 - Fotomicrografia de dolomito granular, com pelóides esparsos, irregulares e vestígios de filmes micríticos. Coloração da calcita por alizarina. Perfil 1, Mina da Bocaina. X.N. $30 x$ 


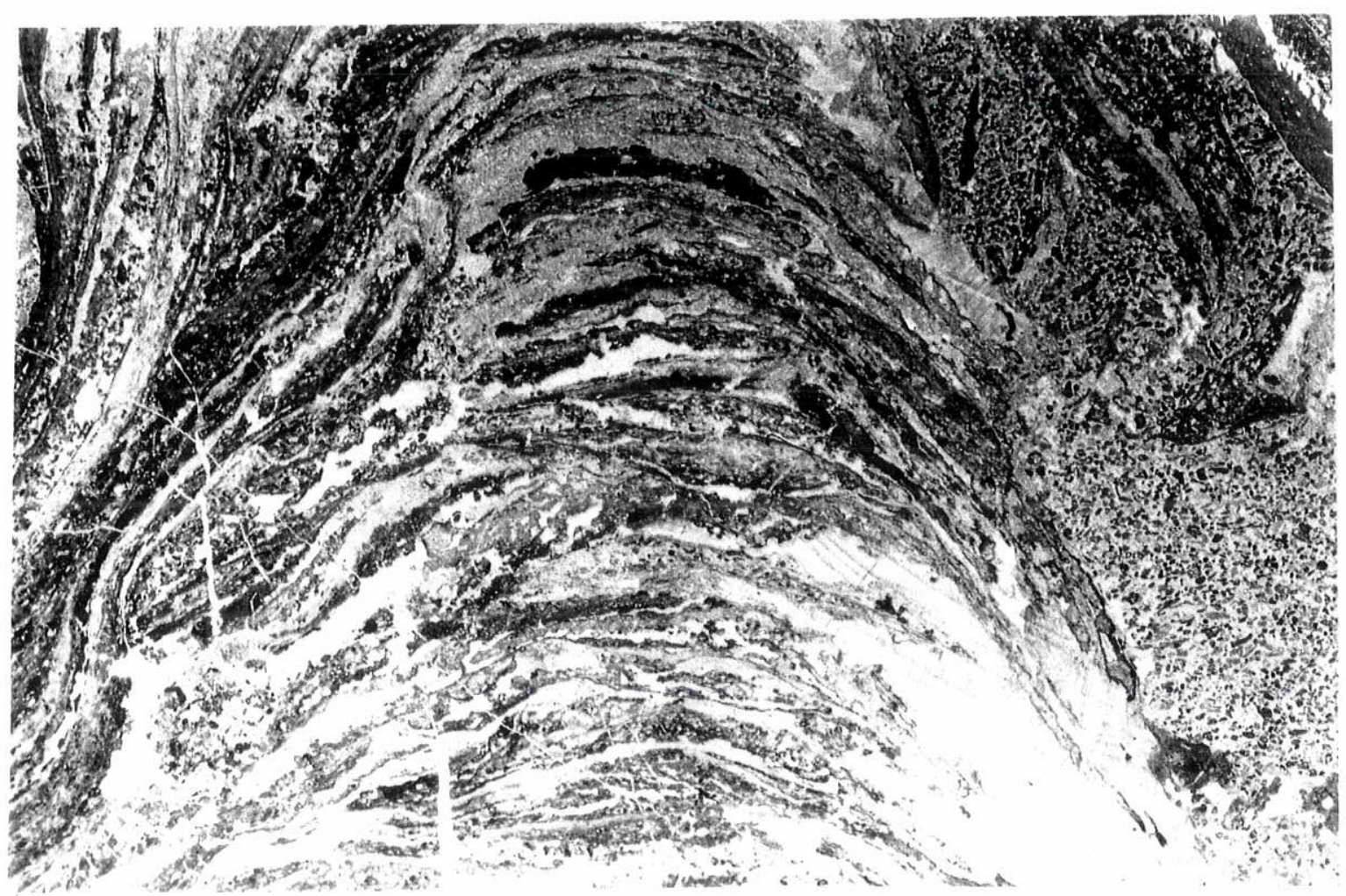

Foto 1 - Fotomicrografia de pequena coluna estromatolítica que apresenta grau de herança regular e onde se observa que as laminações apresentam descontinuidades. Parte basal da Fácies DEcp, no Perfil 4, na mina em atividade da COMIG. L.N. 2,5x

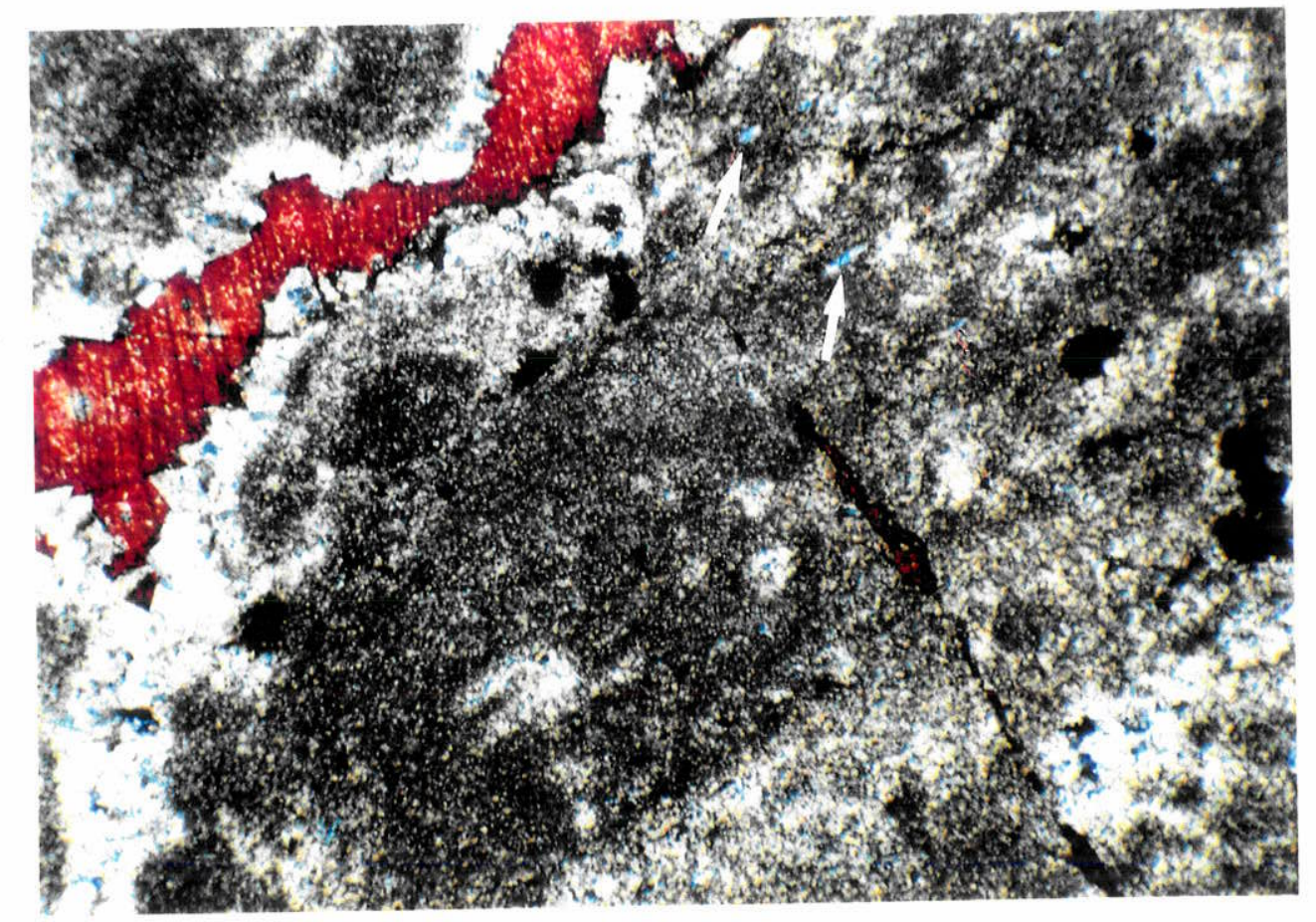

Foto 2 - Fotomicrografia mostrando detalhes da foto anterior, onde as cavidades apresentam franja dolomítica, e têm o centro preenchido por calcita espática (vermelho, por coloração com alizarina); presença de cristais aciculares de anidrita (seta). X.N. 70x 
paulatinamente por microorganismos e lâminas espessas de micrita escura, grumosa, com raros microfitólitos, pelóides, e inúmeros cristais prismáticos, aciculares de anidrita, que apresentam cores de interferência de segunda ordem características (Prancha 26, foto 2). Observa-se ainda cavidades forradas por franja isópaca, dolomítica, preenchidas por mosaico de calcita espática (Prancha 26, foto 2), que no geral são concordantes com a laminação; observa-se também pequenas fraturas preenchidas por calcita espática, mas sem cimento em franja. Freqüentemente a calcita espática apresenta deformação, com maclas retorcidas e onduladas.

Para o topo, observa-se pequenos estromatólitos colunares, dispersos em meio a estromatólitos planares de laminações finissimas. Pequena coluna estromatolítica amostrada (Prancha 27, foto 1), apresenta espessas lâminas granulares, composta por grãos micríticos e microfitólitos, e lâminas escuras, micríticas, de aspecto grumoso (Prancha 27, foto 2). Observa-se pequenas fraturas preencidas por calcita espática, talvez resultantes de processos de ressecação e evidência de laminação fenestral.

5.13 - FÁCIES DEb: Dolomito estromatolítico estratiforme com brecha de dissolução associada

Ocorre na Mina da Bocaina (cota 755 metros), tem cerca de um metro e meio de espessura e continuidade lateral observada por cerca de 10 metros.

É constituido predominantemente por estromatólitos estratiformes, de laminação ondulada, e pseudocolunares; apresenta ainda alguns cumulados esparsos, centimétricos a decimétricos (Prancha 28, foto 1 ).

O topo desse nivel estromatolítico é nítido e irregular, com desniveis centimétricos.

Os estromatólitos estão fortemente dolomitizados, observando-se em lâmina delgada apenas delgados niveis de micrita escura e cavidades semelhantes a fenestrae preenchidas por calcita espática. O dolomito estromatolítico, no topo do biostroma, apresenta evidência de dissolução, com formação de brechas de colapso. Alguns fragmentos exibem franja isópaca, dolomítica, e estão cimentados por calcita espática (Prancha 28, foto 2).

\subsection{4 - FÁCIES DI: Dolomito com laminação irregular}

Ainda no Perfil 1, na Mina da Bocaina, no nível 757 metros, ocorre uma camada de cerca de 80 centímetros de espessura de dolomito aparentemente granular, com 


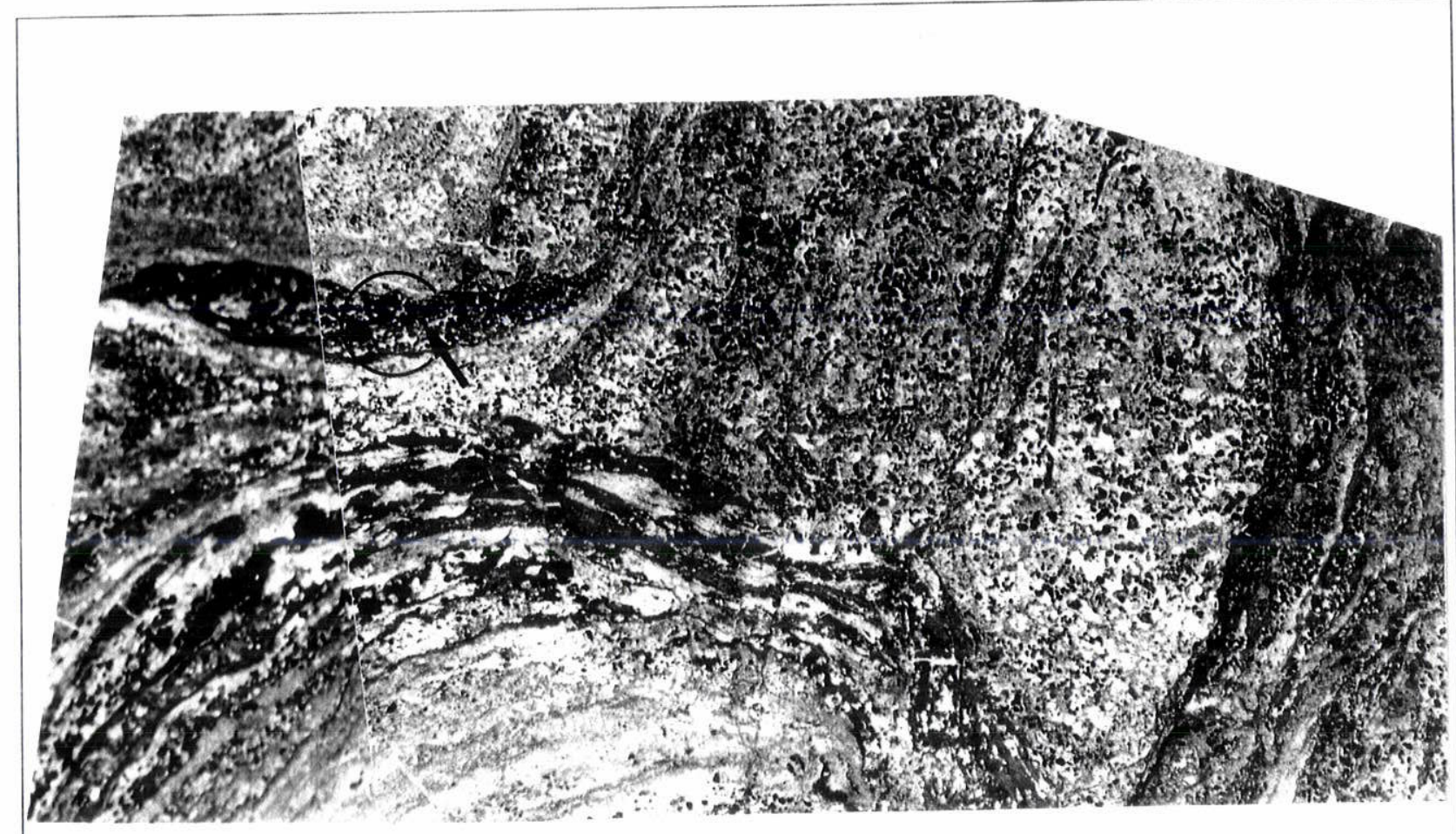

Foto 1 - Fotomicrografia composta de pequena coluna estromatolítica observada no topo da Fácies DEcp, no Perfil 4, na mina em atividade da COMIG. L.N. 5x

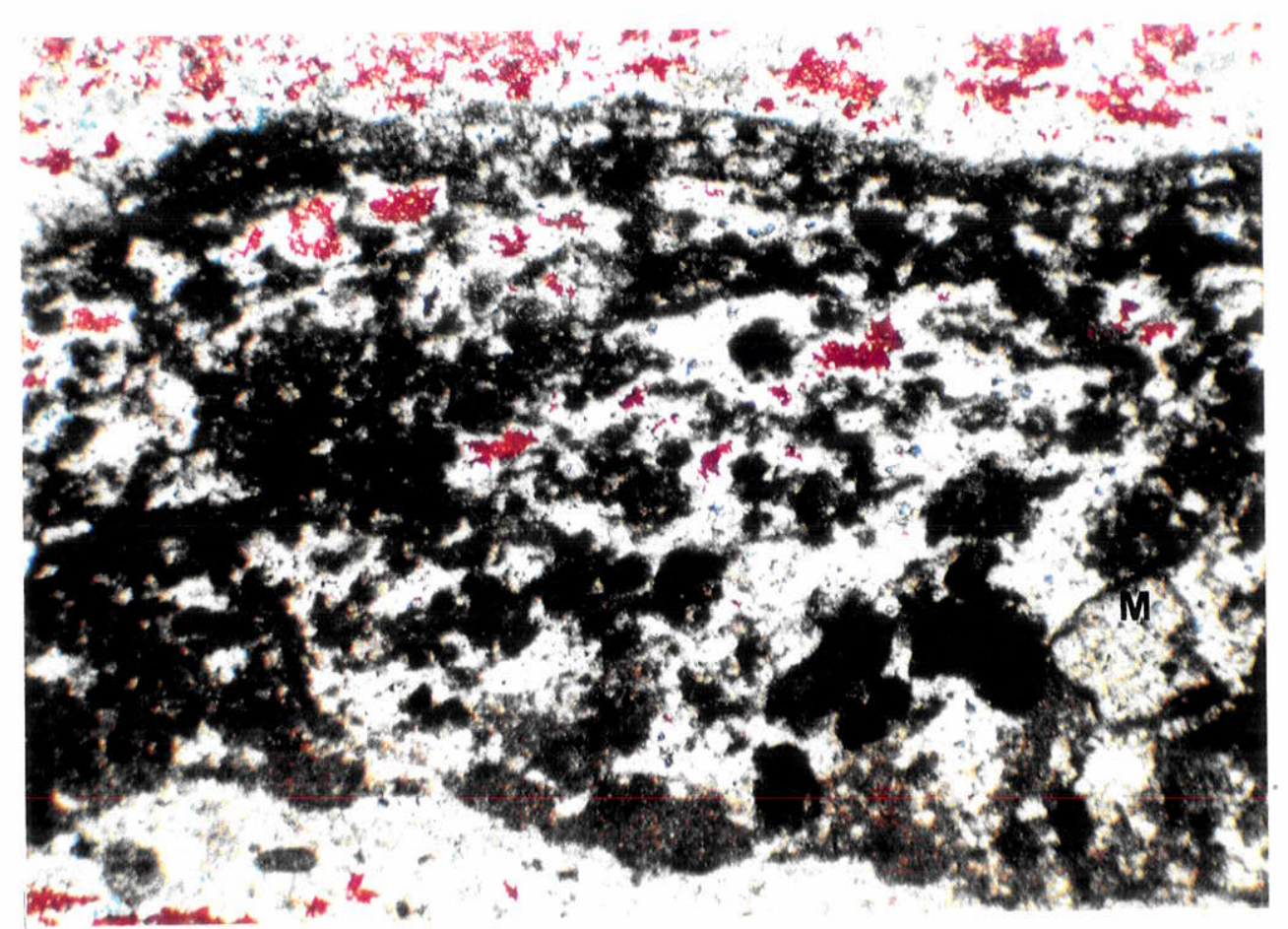

Foto 2 - Detalhe da foto anterior, onde se observa lâmina micrítica com microfábrica grumosa. Presença de microfitólito (M). Coloração da calcita por alizarina. X.N. 35x 


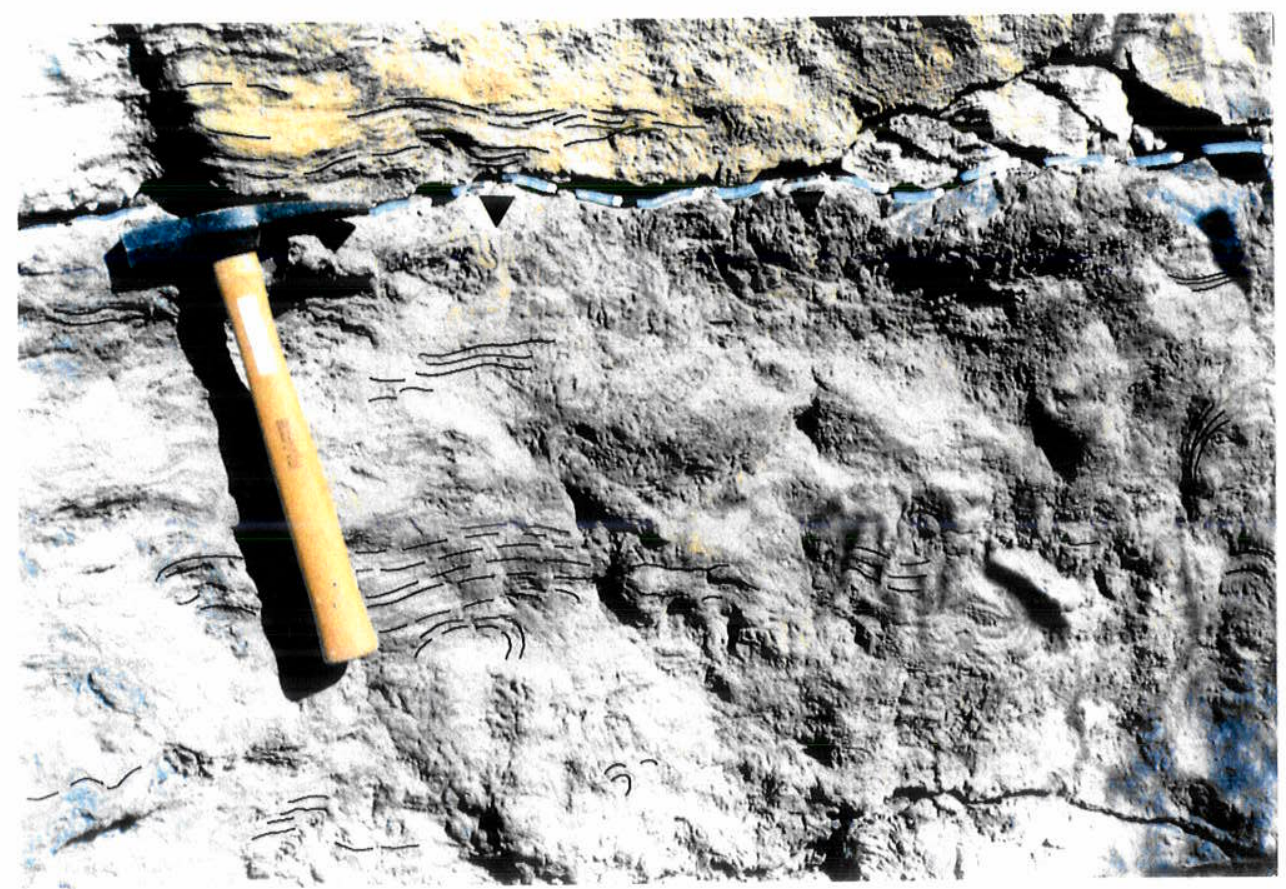

Foto 1 - Dolomito estromatolítico (Fácies DEb), que apresenta no topo brechas de colapso. Acima situa-se a Fácies DI. Mina da Bocaina. Perfil 1.

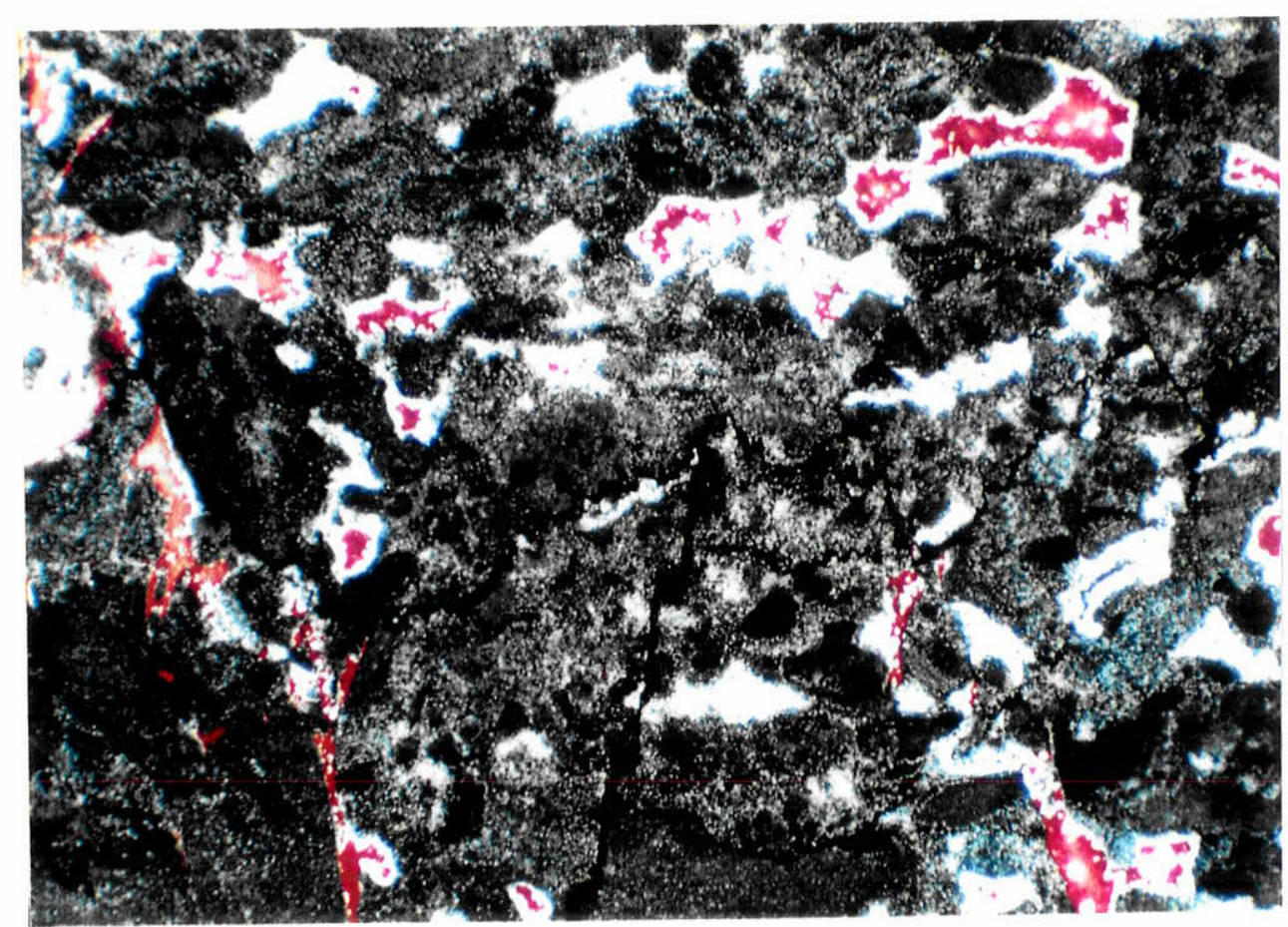

Foto 2 - Fotomicrografia das brechas de colapso que ocorrem no topo da Fácies DEb. As cavidades e fragmentos apresentam franja dolomítica e as cavidades estão preenchidas por calcita espática. Coloração da calcita por alizarina. Perfil 1, Mina da Bocaina. L.N. 20x 
laminações irregulares. Em lâmina delgada, observa-se apenas pelóides esparsos de granulação areia fina ou áreas micríticas irregulares, contendo pequenos pelóides em meio a um mosaico de dolomita microcristalina (Prancha 25, foto 2).

5.15 - FÁCIES DEes: Dolomitos estromatolíticos estratiformes e intercalações de dolomitos não estromatolíticos

Essa fácies está bem representada no Perfil 1, na Mina da Bocaina, com cerca de 20 metros de espessura, embora também seja observada no Perfil 4, na mina em atividade da COMIG. No Perfil 3, na mina abandonada da COMIG, apresenta grande espessura, mas é acessível apenas em blocos rolados (Figuras 7, 8, e 9 ).

Os diversos níveis estromatolíticos descritos na Mina da Bocaina, serão referenciados pela cota (altitude) em que foram observados; a base aflorante da Mina da Bocaina situa-se em torno de 695 metros.

A Fácies DEes é predominantemente composta por estromatólitos estratiformes, sendo bastante homogênea quanto ao aspecto macroscópico (Prancha 29). Feições que permitissem caracterizar o ambiente de desenvolvimento dos estromatólitos com maior segurança foram obtidas através da microestrutura dos estromatólitos.

A maioria das estruturas estromatolíticas estudadas é constituida por dolomitos finamente cristalinos e desenveu-se em ambiente de baixa energia, com intercalaçöes de lâminas e leitos granulares ou placóides. Niveis bioconstruidos, mas não estromatolíticos, constituem esteiras microbianas e atuaram como estabilizadoras dos sedimentos.

\subsection{1 - Dolomitos não estromatolíticos}

Os dolomitos não estromatoliticos constituem delgados niveis ou camadas granulares, e são compostos por microfitólitos, pelóides e intraclastos.

Os niveis mais espessos podem apresentar, na base, laminação plana a ondulada, seguida por estratificação cruzada por ondas; marcas onduladas observadas em perfil, apresentam comprimento de onda de até 1 metro. Os níveis mais delgados tendem a apresentar gradaçäo normal.

Na cota 766,5 metros (Mina da Bocaina), ocorre um nivel de dolarenito, com cerca de 70 centímetros de espessura. Apresenta um leito basal com laminação plana a ondulada, seguido por estratificação cruzada por ondas compondo sets centimétricos a decimétricos, truncados por grandes ondulaçōes (Prancha 30, topo da foto 1). 


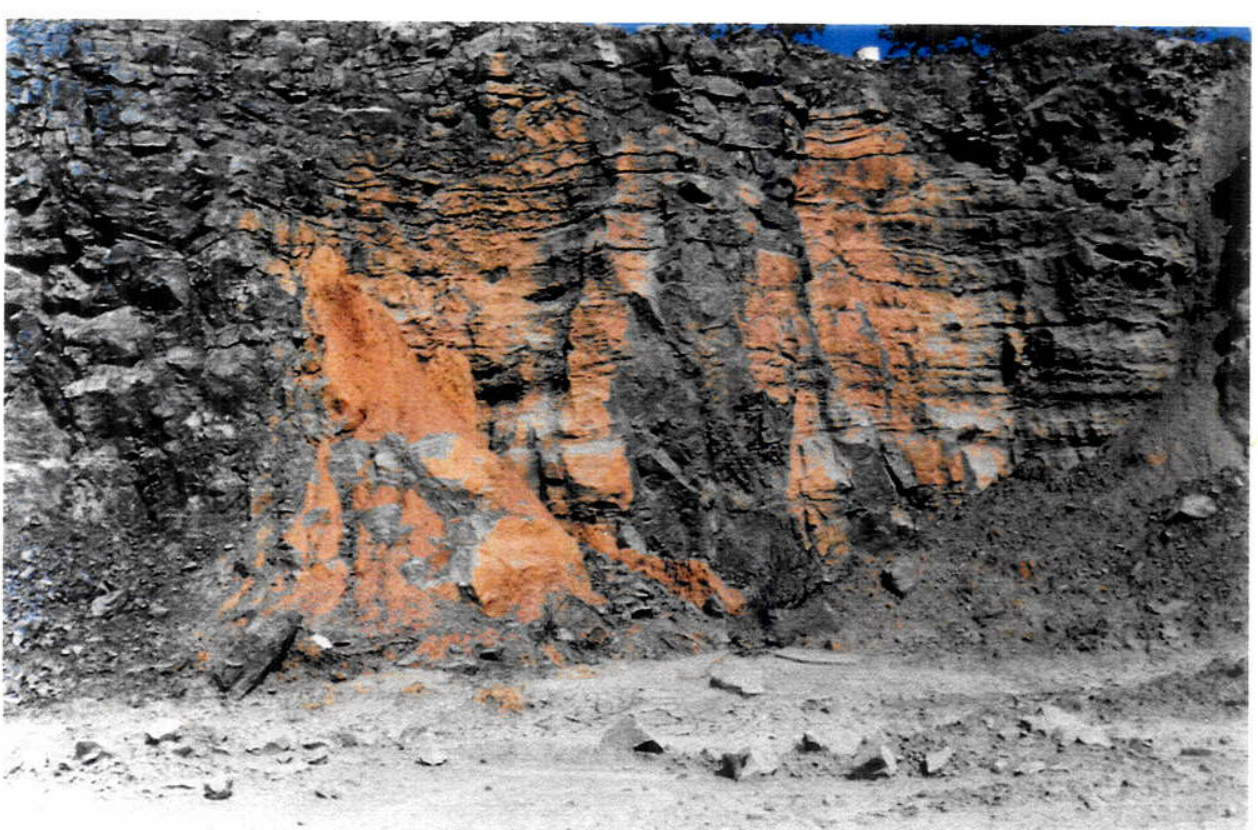

Foto 1 - Vista geral do nível 770 a 780 metros, na Mina da Bocaina. Fácies DEes.

Foto 2 - Detalhe da foto anterior, onde se observa, na parte basal (771 metros) espesso nível de packstone, limitado no topo por uma superfície ondulada. Acima predominam estromatólitos estratiformes com lentes de silex. A escala da foto corresponde a sete centímetros.

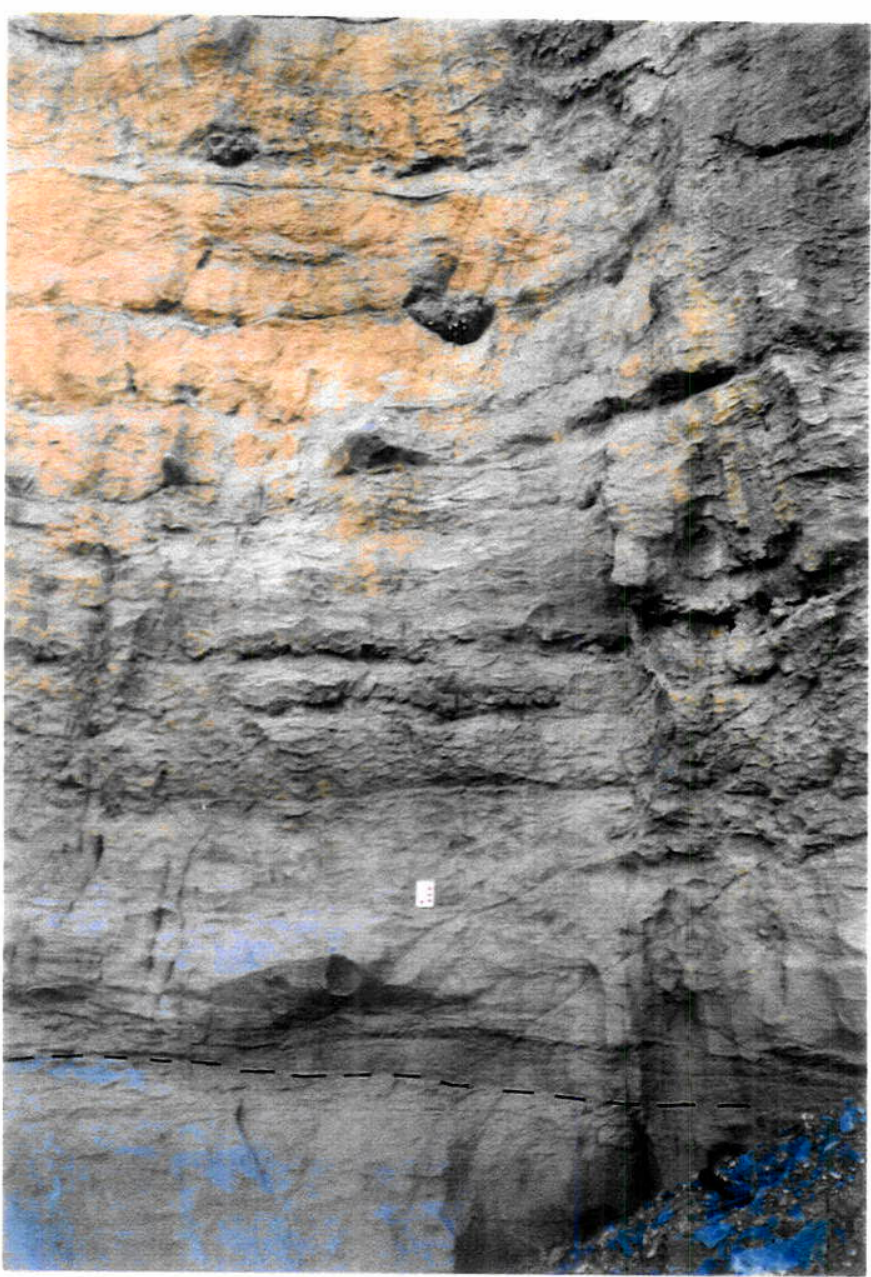

Foto 2 


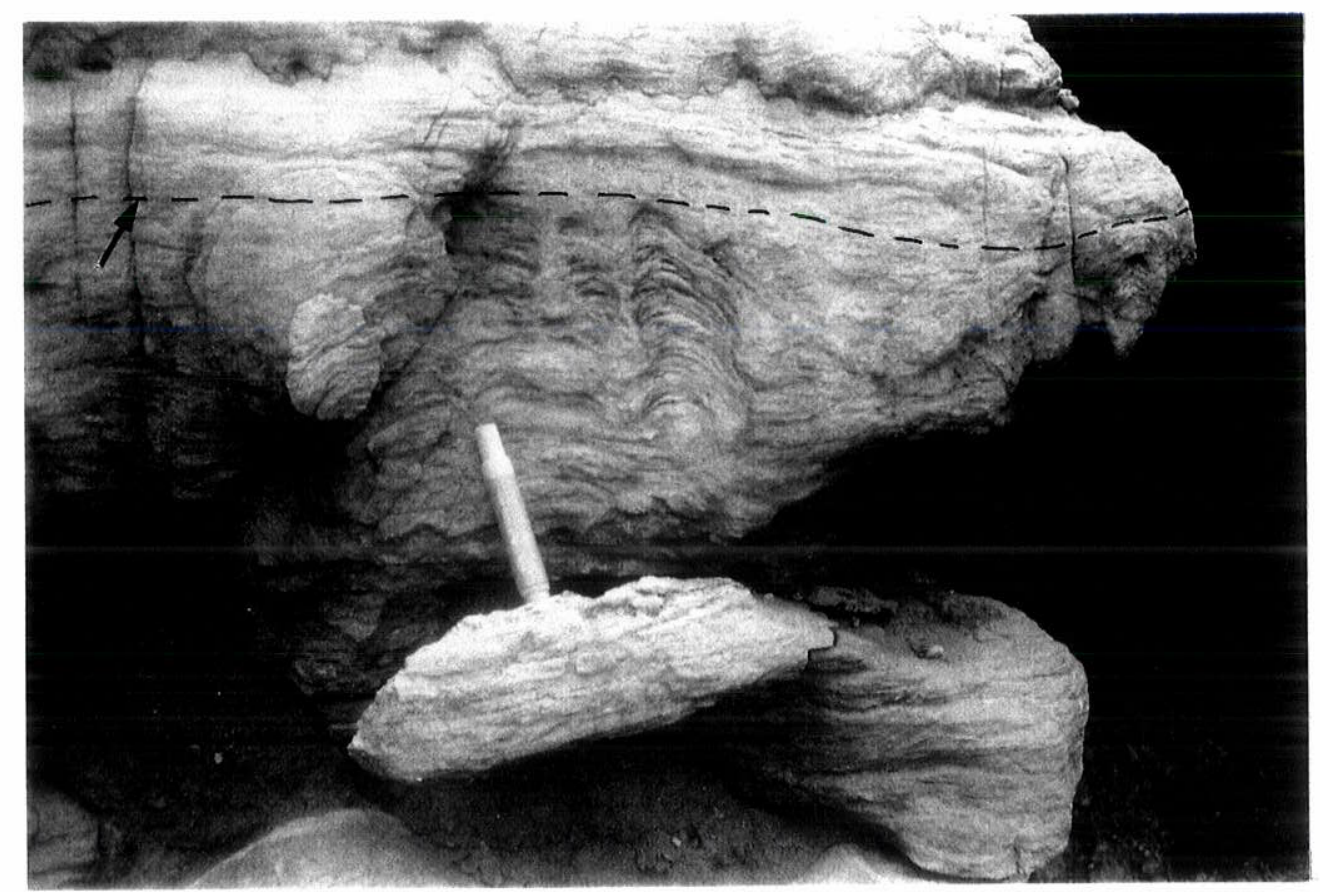

Foto 1 - Afloramento da Fácies DEes, no Perfil 1, na Mina da Bocaina. na base ocorre um dolomito estromatolítico, que é cortado no topo por uma superfície ondulada, sobre a qual se depositou o dolarenito constituído por microfitólitos, com estratificação cruzada por ondas (cota 766,5 metros).

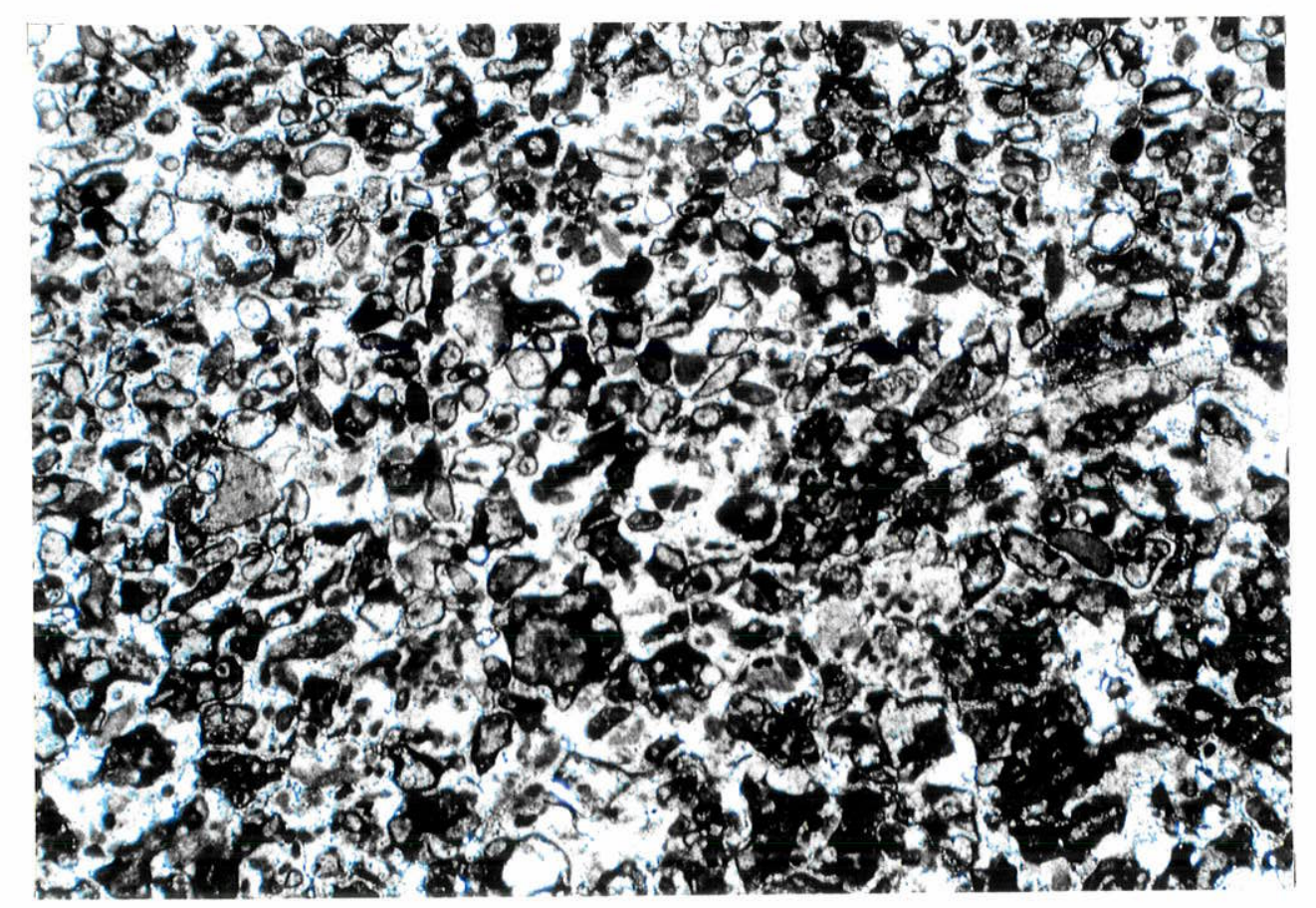

Foto 2 - Fotomicrografia do dolarenito com microfitólitos. Observar a grande variedade morfológica dos grãos. Topo da foto 1. L.N. 10x 
Texturalmente, constitui um grainstone de granulação grossa a muito grossa, composto por microfitólitos de formas variadas (Prancha 30, foto 2). 0 arcabouço da rocha é aberto e os bioclastos exibem delgada franja isópaca acicular, originalmente aragonítica, que foi posteriormente dolomitizada de forma mímica, isto é, sem perda de suas características originais. É um dolarenito que praticamente não apresenta deformação; observa-se apenas silicificação incipiente em pequenas áreas, geralmente no núcleo dos bioclastos.

No nivel 771 metros ocorre um nível arenoso, com cerca de um metro e meio de espessura, que apresenta estratificação cruzada por ondas e pequenas marcas onduladas. Litologicamente, é um dolarenito de granulação muito grossa, mal selecionado, texturalmente um packstone, de arcabouço aberto. É composto por microfitólitos, de granulação muito fina a fina e areia grossa a grânulos, que apresentam vestígios de franja isópaca acicular (Prancha 31, foto 1).

Sobre esse dolarenito, assenta-se, através de marcas onduladas, um nivel granular, de espessura decimétrica; texturalmente é um packstone extremamente mal selecionado. Contém grãos nas fraçōes areia fina a média (dominante), areia muito grossa e ainda grânulos. A composição dos aloquímicos é extremamente variável, com microfitólitos, oóides de granulação areia média, pelóides, oólitos superficiais (granulação areia fina), agregados de aspecto botrioidal (grânulos) e intraclastos laminados e micríticos (Prancha 31, foto 2).

Entre as intercalações rudáceas, tem-se, na Mina da Bocaina (cota 767 metros), um delgado nível de dolorrudito que constitui uma brecha sustentada pelos clastos, fracamente gradada e composta por intraclastos centimétricos, lamelares, eventualmente encurvados.

\subsection{2 - Dolomitos estromatolíticos estratiformes}

Os dolomitos estromatolíticos estratiformes foram observados nos perfis 1 e 4, mas os dados apresentados referem-se especialmente à Mina da Bocaina (Perfil 1), onde são mais facilmente acessiveis.

Os estromatólitos compõem biostromas, são estratiformes a pseudocolunares, de laminação plana a ondulada e eventualmente apresentam pequenas formas colunares ou dômicas muito subordinadas.

Os biostromas apresentam truncamentos por ondas, intercalaçöes de material granular e/ou placóide, níveis com gretas de contração e cristais de evaporitos, 


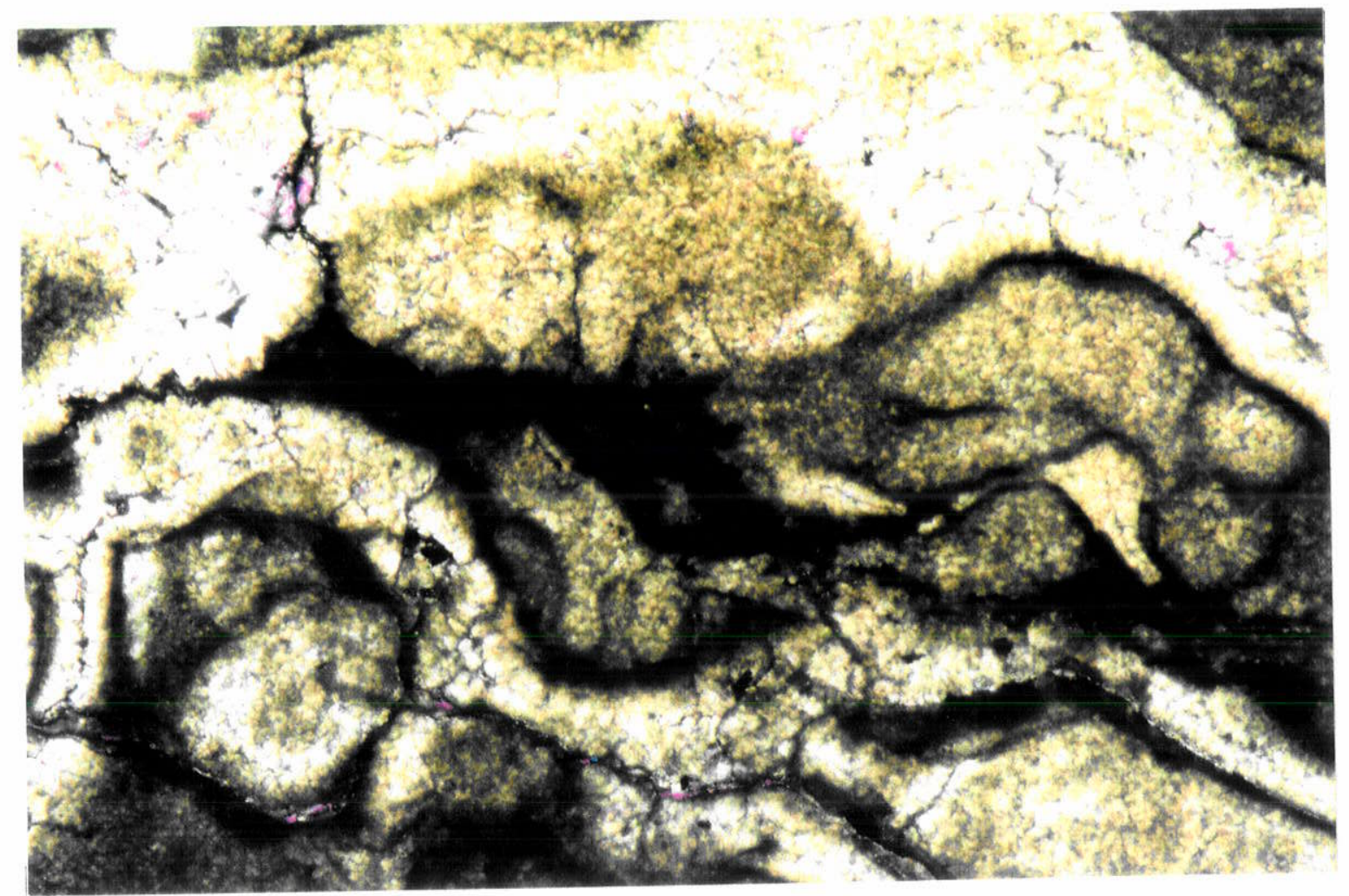

Foto 1 - Fotomicrografia de detalhe de microfitólito da foto 2, Prancha 30. Observar vestígios de franja isópaca acicular originalmente aragonítica, ao redor dos grãos. P.G./X.N. $100 x$

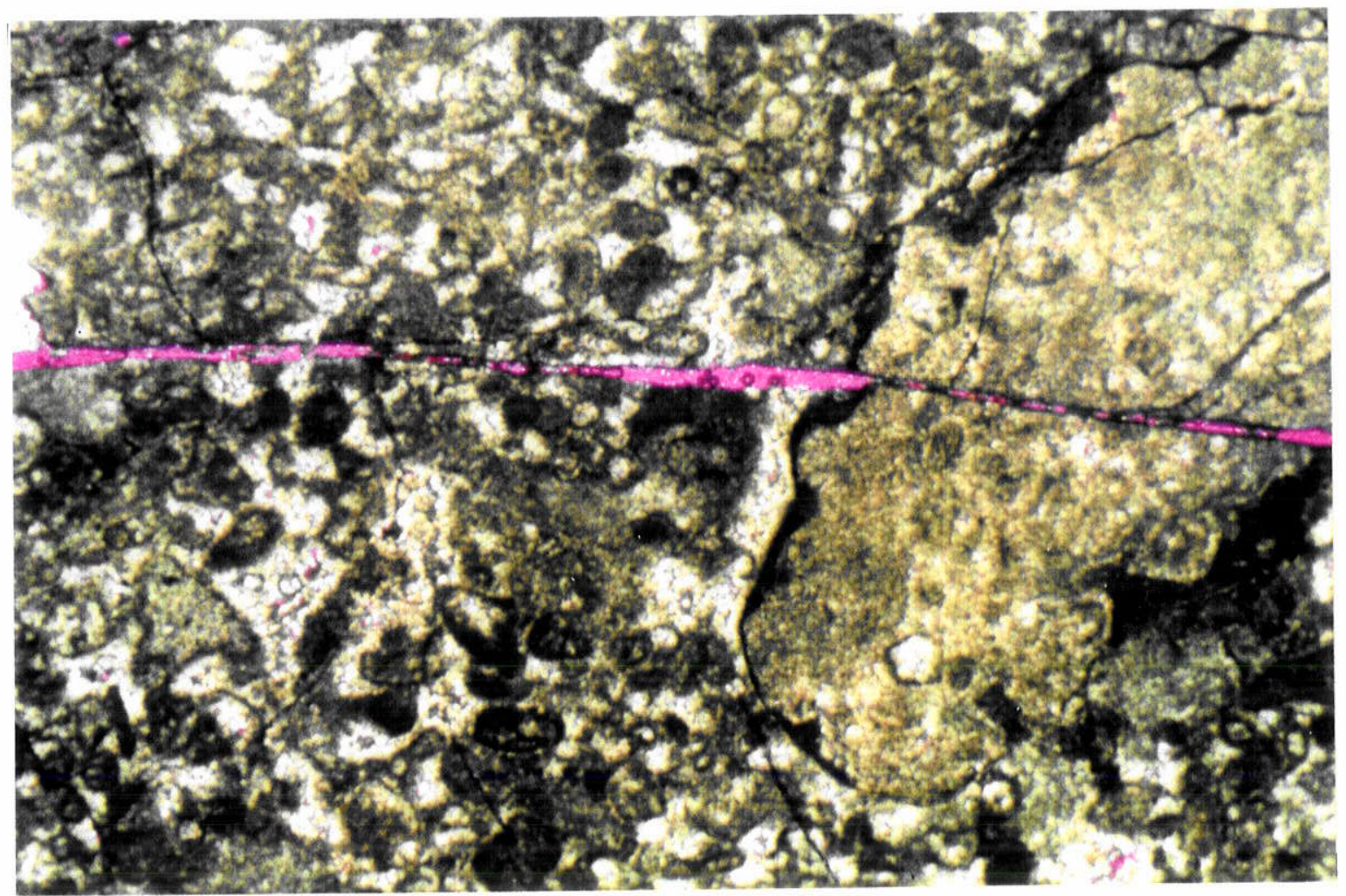

Foto 2 - Fotomicrografia de packstone mal selecionado (Fácies DEes), no Perfil 1, na Mina da Bocaina. P.G./X.N.25x 
especialmente anidrita. Esses elementos no geral indicam os limites naturais dos biostromas e sugerem a ação de fluxos de tempestades ou ligeiras flutuações do nivel do mar.

A Fácies DEes apresenta, na Mina da Bocaina, próximo à base (cota 765 metros), um bioherma estromatolitico, com cerca de 1 metro de espessura, composto por maciços estromatolíticos de aspecto arborescente, constituidos por estromatólitos pseudocolunares a colunares (Prancha 32), que apresentam espaçamento variável entre si de meio a um metro. Lateralmente aos maciços estromatolíticos, as estruturas são menos proeminentes, os estromatólitos são estratiformes, e as laminações apresentam espessuras variadas, com intercalaçőes importantes de material granular.

Os estromatólitos têm em média 80 centímetros de altura e seção ovalada, cujo diâmetro maior pode atingir 75 centimetros. Macroscopicamente, as laminações são milimétricas, têm perfil convexo a plano e apresentam pequenas descontinuidades. $A$ base dos maciços estromatolíticos é sempre constituida por domos ou colunas centimétricas, onde se nota a presença de parede lateral, que desaparece em direção ao topo do estromatólito.

Em lâmina delgada observa-se que os domos e colunas apresentam relevo positivo, tendo crescido livres dos sedimentos adjacentes. Apresentam laminações muito espessas e de baixo grau de herança, pois observa-se superposição de três ou quatro lâminas, e então ocorrem discontinuidades que são devidas ao desenvolvimento do estromatólito, e não a processos de erosão (Prancha 33, foto 1).

As laminações são bastante características com limites nítidos entre si. Foram observados 3 tipos principais de microestrutura: lâminas de microespato dolomitizado contendo grãos, espessas lâminas micriticas dolomitizadas e filmes micríticos.

- As lâminas de microespato dolomitizado com grãos são de cor cinza claro e apresentam relevo; os gräos são peloidais e sua distribuição nas lâminas é irregular não se concentrando na base das mesmas.

- As lâminas micríticas são espessas e podem às vezes constituir uma lâmina composta (espessura de até quatro milimetros), onde se observa niveis internos mais claros, raros grãos e vestígios de estruturas filamentosas, em especial na base e topo da laminação (Prancha 33, foto 2). É um nível de origem microbiana, praticamente sem aporte de material externo.

- Os delgados filmes micríticos dolomitizados são nítidos, extensos e regulares; capeiam as lâminas com grãos. 


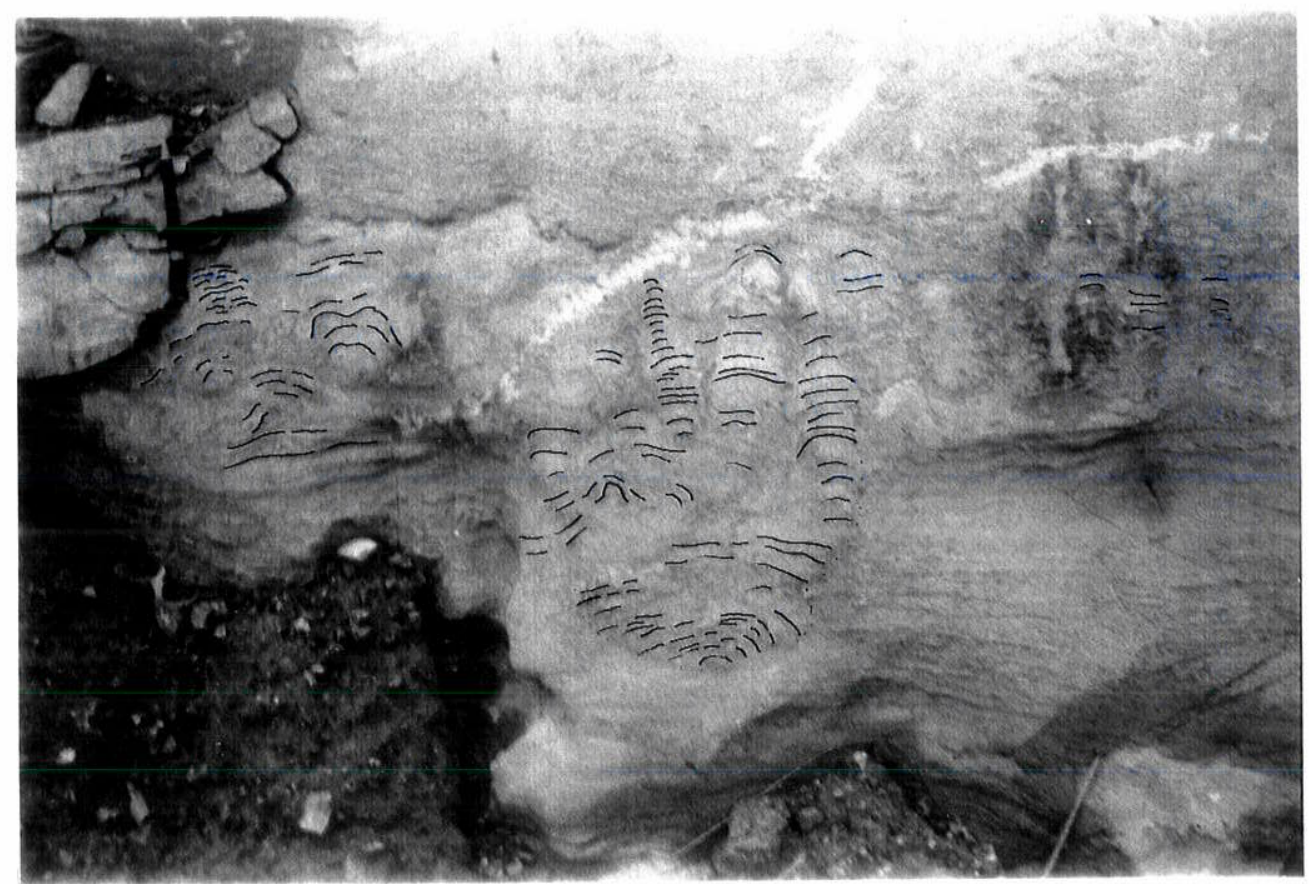

Foto 1 - Afloramento com estromatólitos em "maciços arborescentes" na Mina da Bocaina, Perfil 1. Fácies DEes.

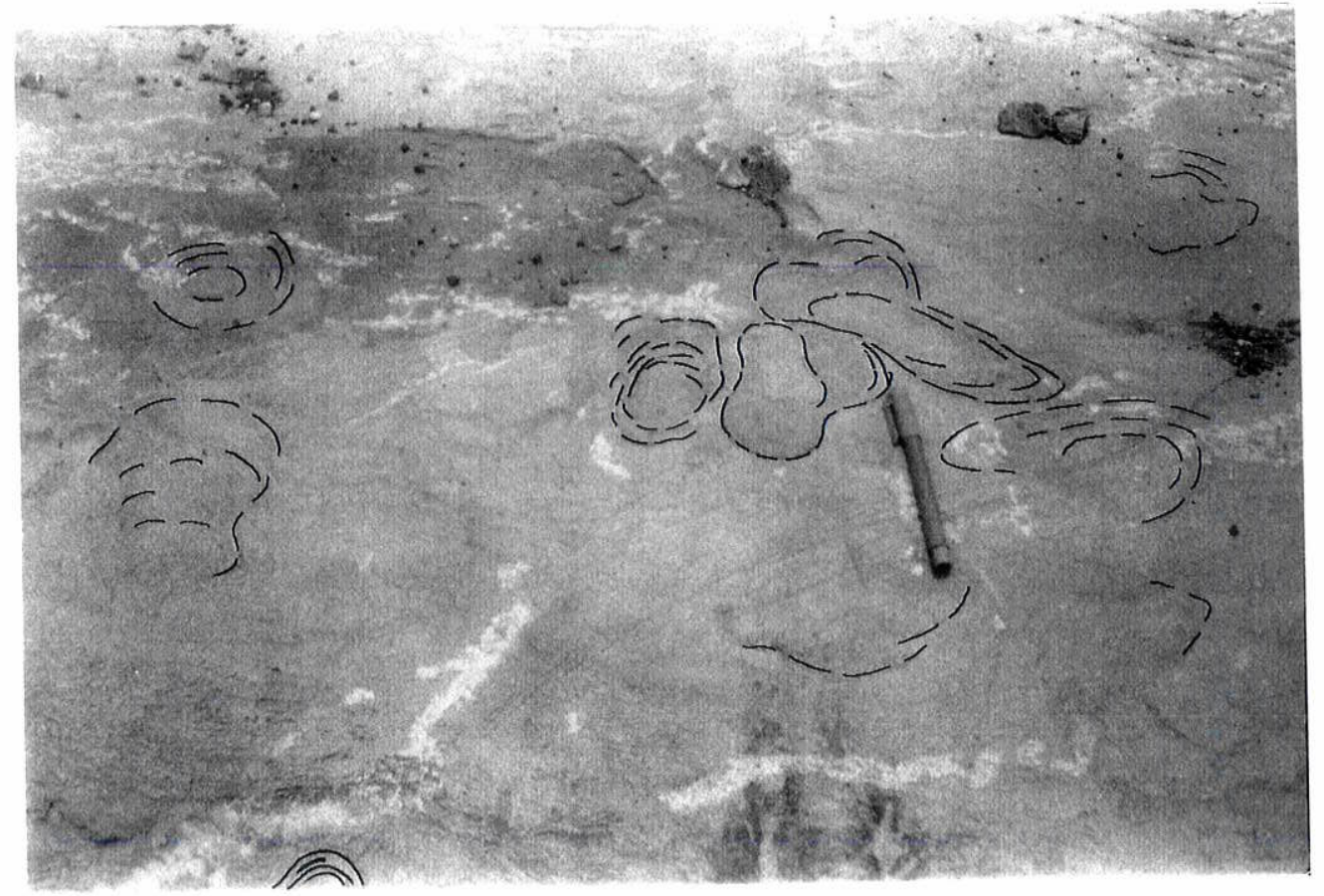

Foto 2 - Estromatólitos em "maciços arborescentes" visto em planta. Perfil 1, Mina da Bocaina. 


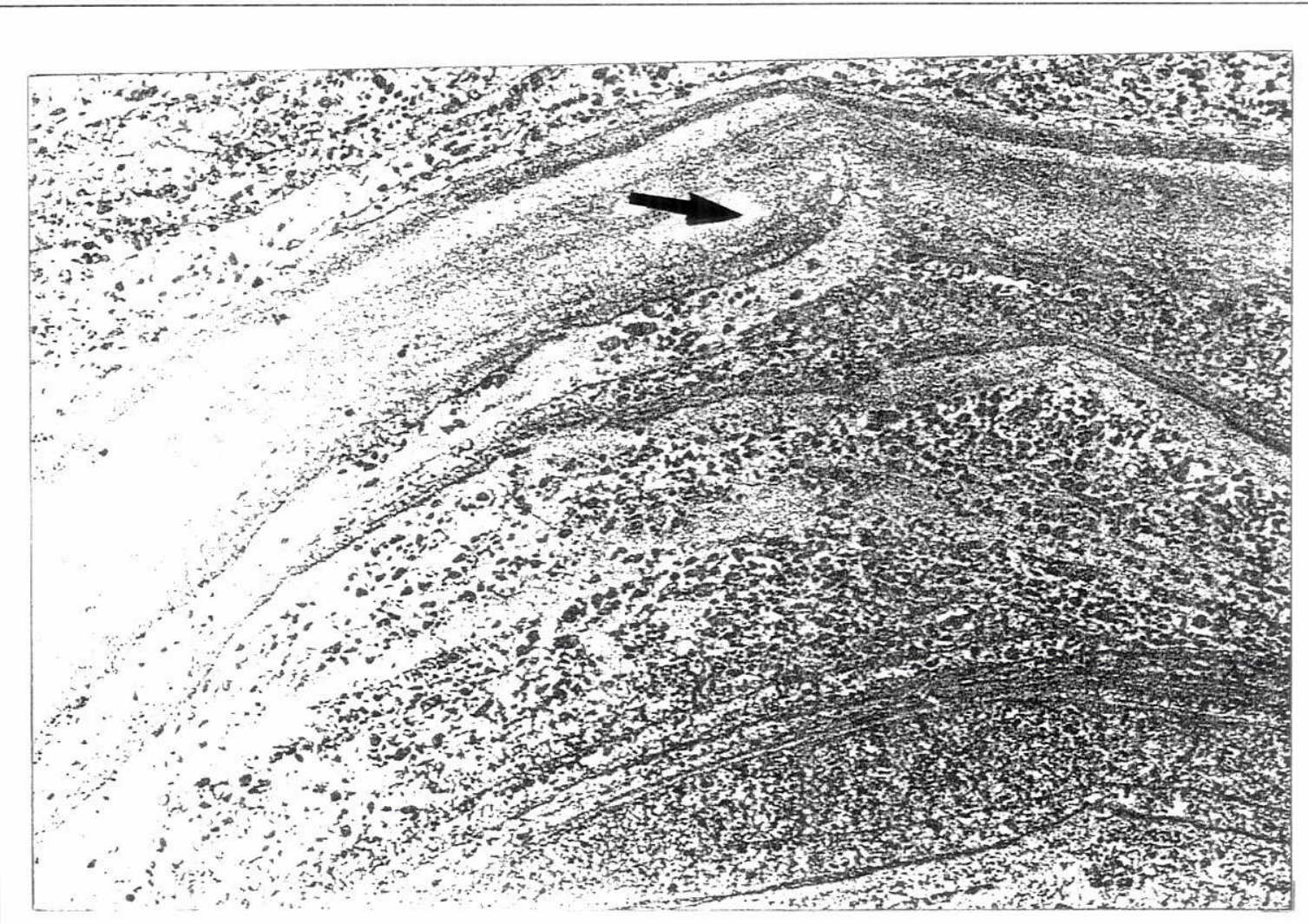

Foto 1 - Fotomicrografia de dolomito estromatolítico da Fácies DEes, onde se alternam lâminas granulares e lâminas micríticas, microbianas. Próximo ao topo, parece existi vestígios de estruturas semelhantes a filamentos. Perfil 1, Mina da Bocaina. L.N. 10x

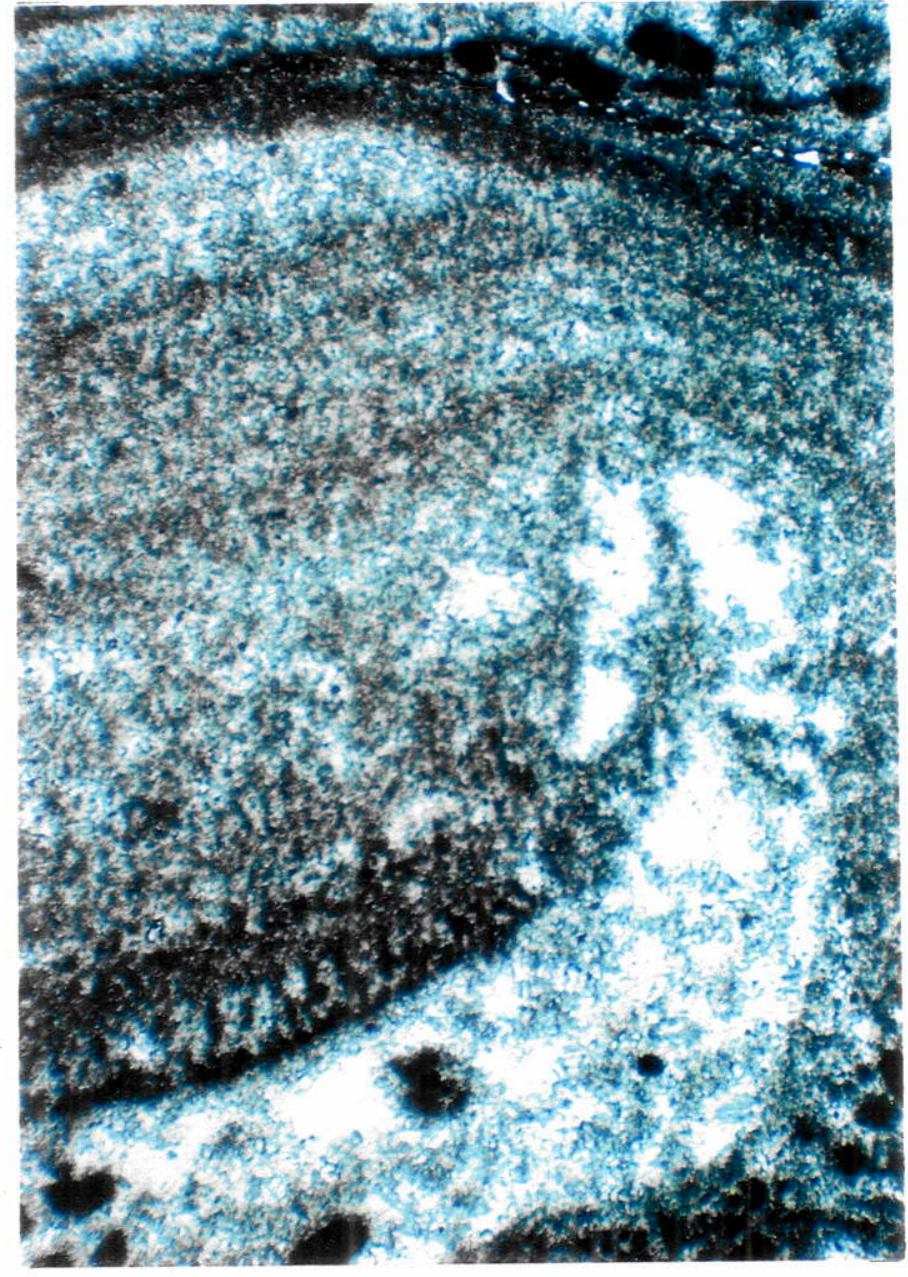

Foto 2 - Fotomicrografia de detalhe da área que apresenta textura que lembra filamentos eretos, com material granular. X.N. 60x 
Acima dos estromatólitos em "maciços arborescentes" os estromatólitos são predominantemente estratiformes a pseudocolunares, com formas colunares esparsas (cota 766 metros) e compöem um biostroma. São capeados pelo nivel de grainstone composto por microfitólitos com estratificação cruzada por ondas (Prancha 30, parte superior da foto 1).

Os estromatólitos colunares são assimétricos, com colunas decimétricas ligeiramente obliquas, que apresentam parede lateral (Prancha 34, foto 1); ocorrem ainda pequenas formas dômicas esparsas.

Lâmina delgada de pequena coluna estromatolítica apresenta as seguintes microestruturas:

-Tapete micrítico espesso, de cor cinza claro; é constituído por microespato dolomitizado, e contém pequenos grãos micríticos esparsamente distribuídos.

-Filmes micríticos, delgados e contínuos, de cor cinza escuro.

-Nivel micrítico dolomitizado de cor escura, irregular, com limite superior e continuidade pouco nitidos; esse nivel parece exibir internamente delgados filmes micríticos, que poderiam ser microbianos quanto à origem. Observa-se ainda, inúmeros cristais aciculares de anidrita.

A parede lateral do estromatólito apresenta-se como um nível à parte, sendo constituida por microfitólitos, que podem se apresentar aglutinados verticalmente, formando parte da parede (Prancha 34, foto 1). Lateralmente ao estromatólito, os microfitólitos constituem um grainstone, e apresentam delgada franja isópaca acicular (Prancha 34, foto 2).

Acima do nivel de dolarenito, os estromatólitos são estratiformes, de laminação plana, com raras formas dômicas esparsas, centimétricas. Exibem laminação fenestral e evidências de ressecação esporádica, com tapetes microbianos litificados, fraturados e gretas de ressecação (Prancha 35). São recobertos pelo nível de dolorrudito que ocorre na cota 767 metros.

Acima desse nivel brechóide reaparecem estromatólitos estratiformes de laminação plana com pequenas formas dômicas esparsas, mas com microestrutura diferente da apresentada dos estromatólitos situados abaixo do dolorrudito. As laminações são muito espessas, devido ao aprisionamento de grãos em grande quantidade, e apresentam inúmeras descontinuidades (Prancha 36, foto 1). As principais microestruturas observadas constituem pares, formados por lâminas espessas e irregulares, granulares, compostas por microfitólitos e pelóides e lâminas micríticas, possivelmente de origem microbiana. Alguns dos níveis granulares constituem verdadeiros grainstones estabilizados por tapetes 

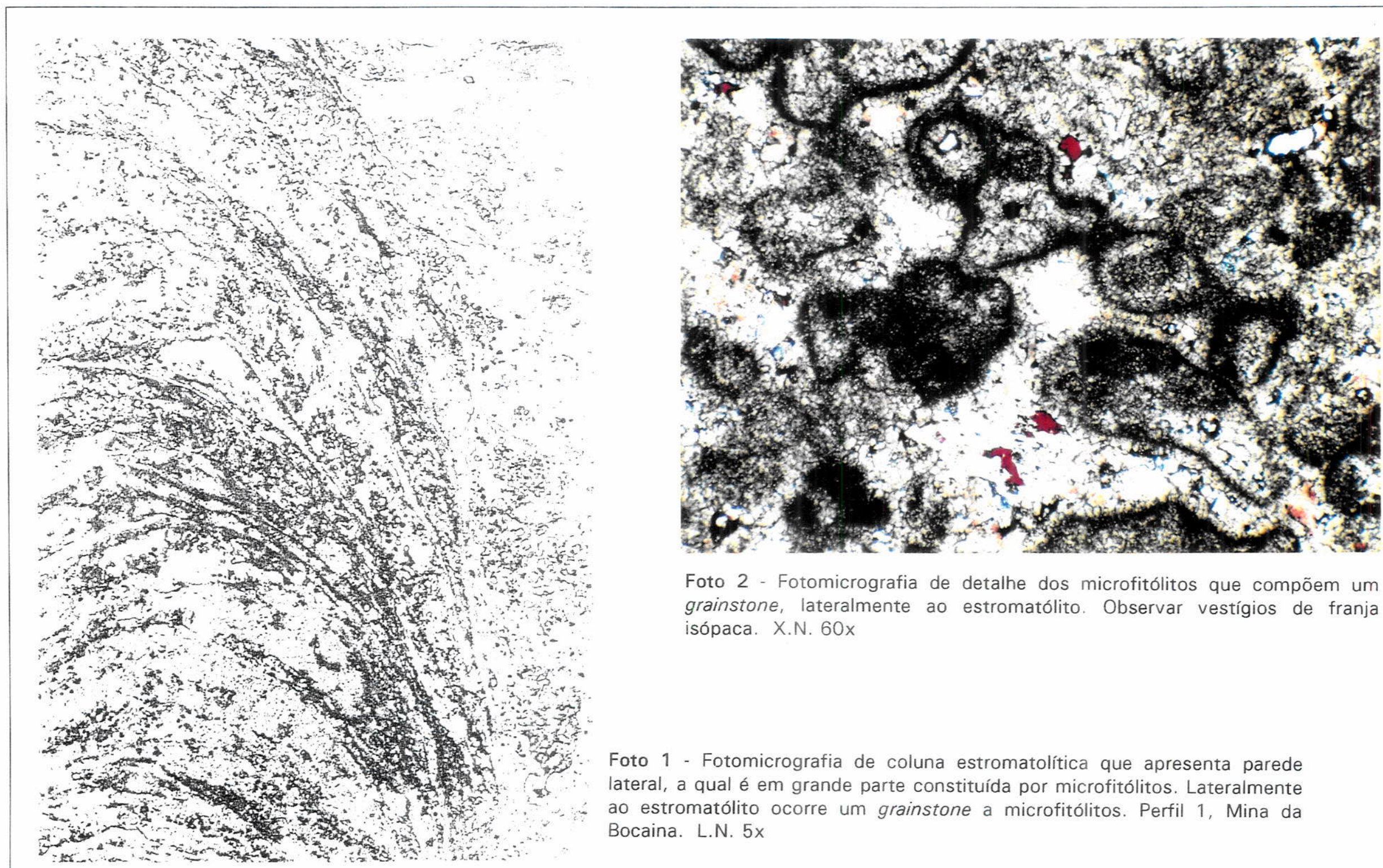

Foto 2 - Fotomicrografia de detalhe dos microfitólitos que compõem um grainstone, lateralmente ao estromatólito. Observar vestígios de franja isópaca. X.N. 60x

Foto 1 - Fotomicrografia de coluna estromatolítica que apresenta parede lateral, a qual é em grande parte constituída por microfitólitos. Lateralmente ao estromatólito ocorre um grainstone a microfitólitos. Perfil 1, Mina da Bocaina. L.N. $5 x$ 


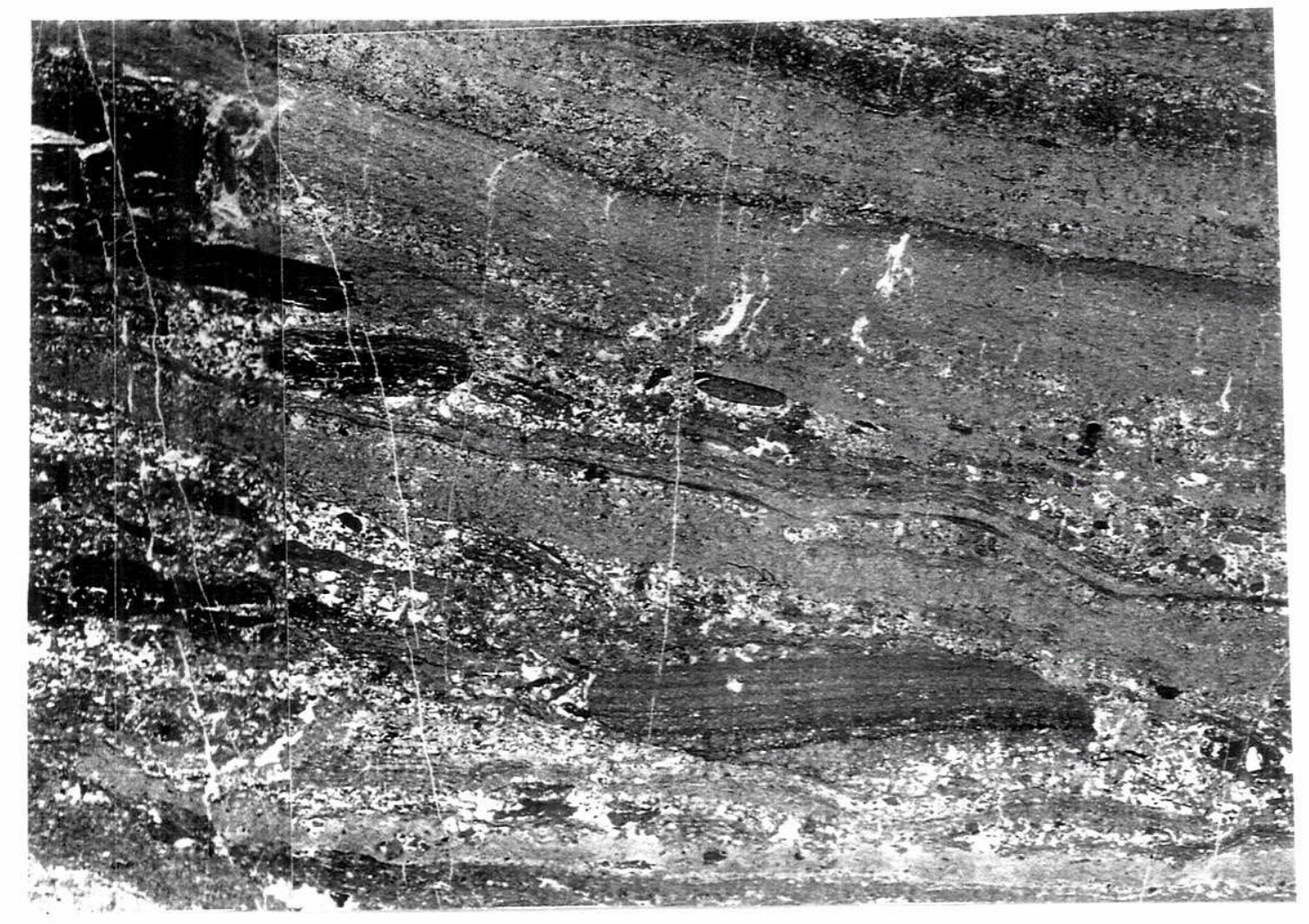

Foto 1 - Fotomicrografia de estromatólitos de laminação plana, que apresentam evidência de ressecação esporádica, com níveis microbianos litificados e fraturados. Perfil 1, Mina da Bocaina. L.N. 5x

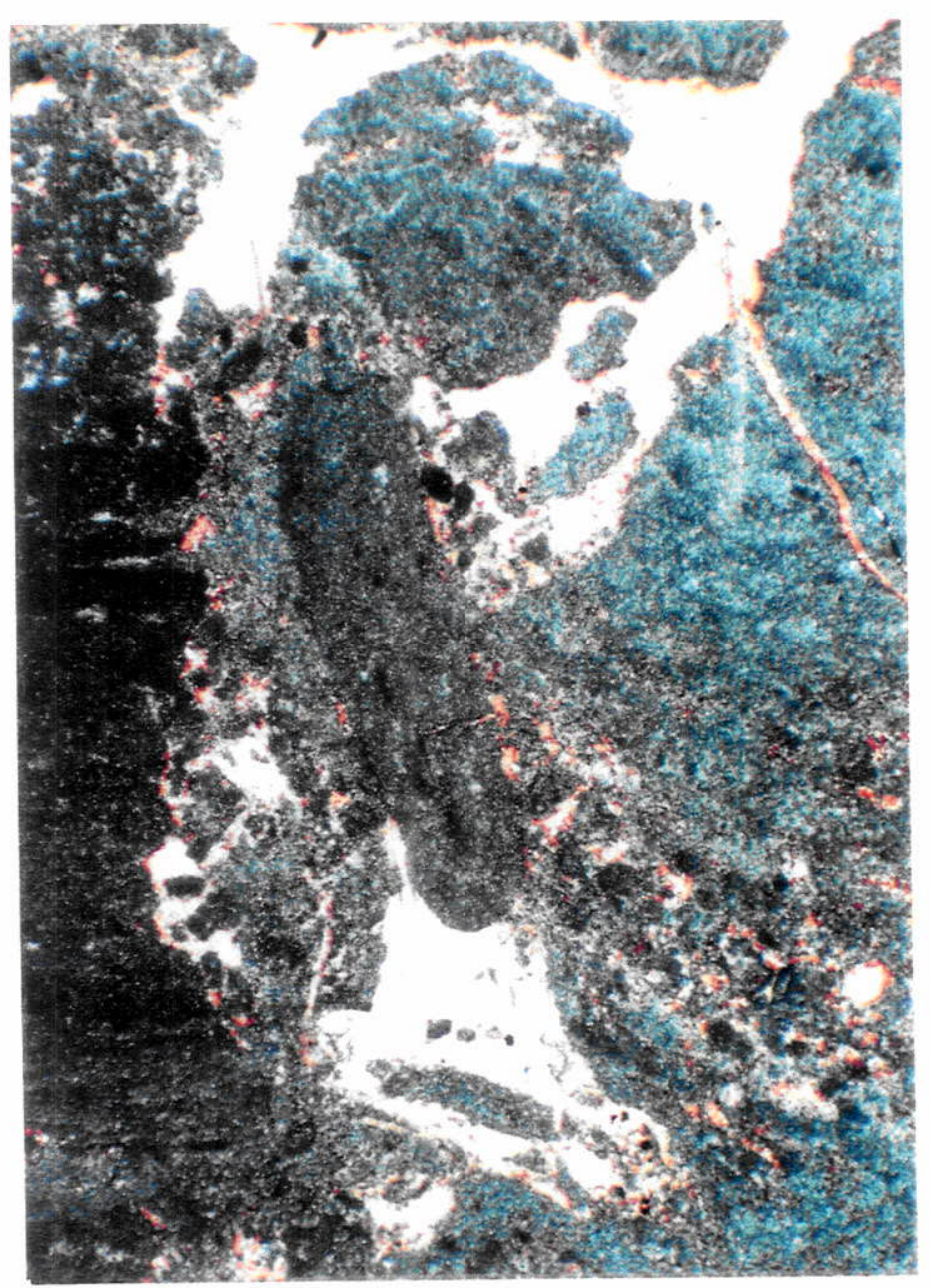

Foto 2 - Fotomicrografia de detalhe da foto anterior, onde se observa níveis com gretas de ressecação, que são em parte preenchidas por sedimentos, e cimentadas por calcita espática. Coloração rósea da calcita por alizarina. X.N. 30x 


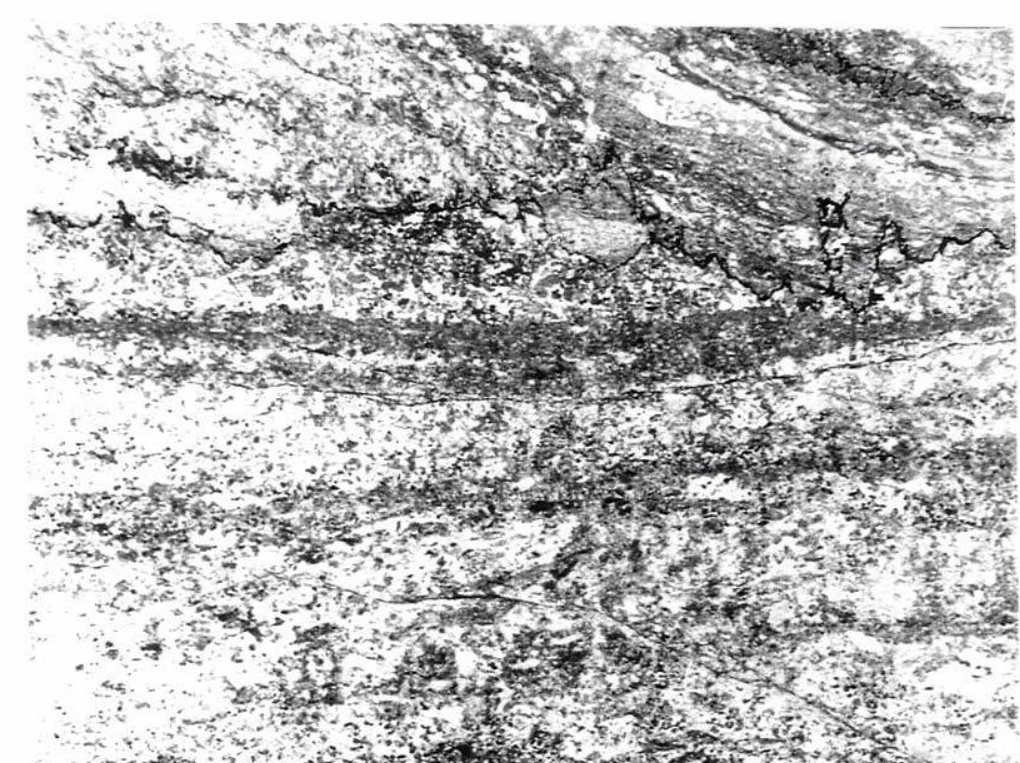

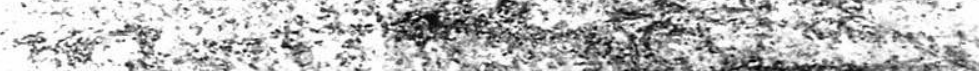

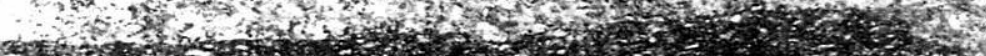

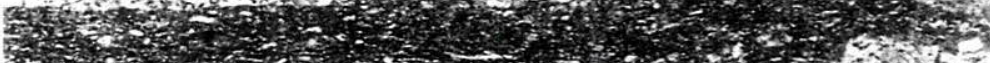

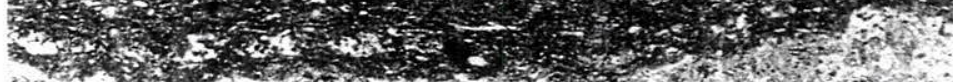

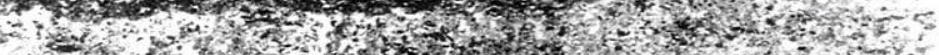

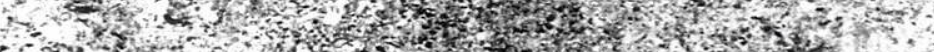

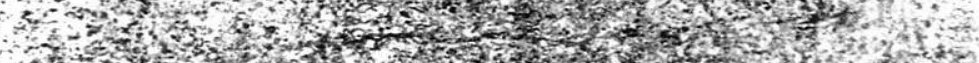

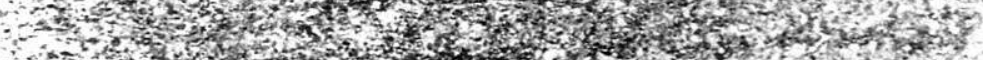
4.

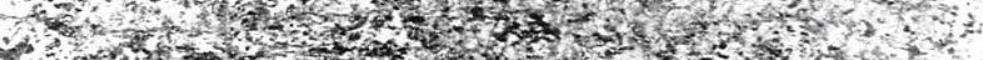

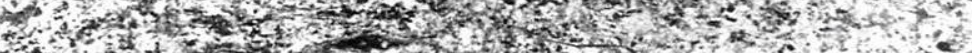

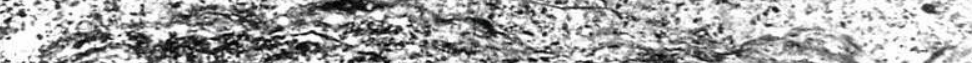

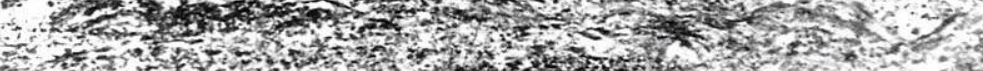
r.t.

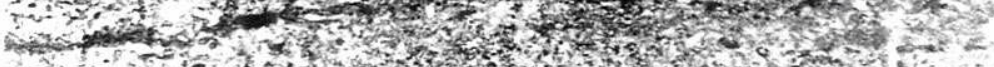
How

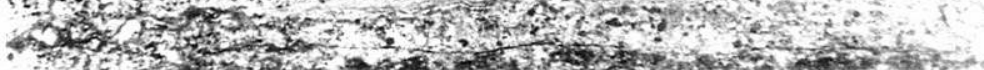

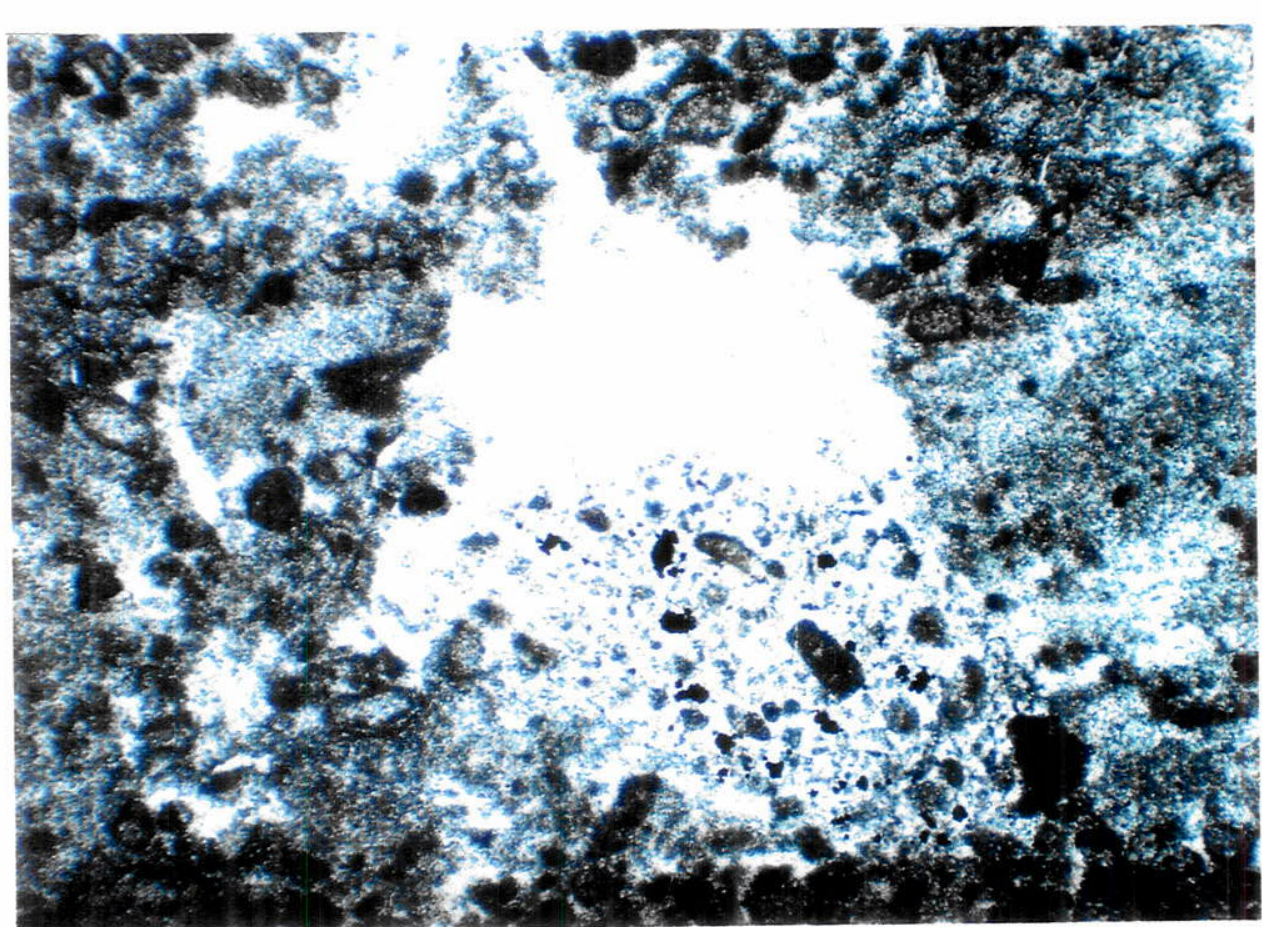

Foto 2 - Fotomicrografia de detalhe da foto 1 , onde se observa cavidade parcialmente preenchida por sedimentos e cimentada por calcita espática, uma feição de diagênese vadosa. X.N. 40x

Foto 1 - Fotomicrografia de estromatólito planar que apresenta espessos níveis granulares, inúmeras discontinuidades e feições de diagênese vadosa. Perfil 1, Mina da Bocaina. L.N. 5x 
microbianos. As lâminas micríticas eventualmente apresentam grãos peloidais e microfitólitos, semelhantes aos que compöem os niveis granulares. Nota-se ainda laminaçäo fenestral, pequenas fraturas e feiçōes de diagênese vadosa, como cavidades com preenchimento parcial por sedimento, caracterizando feição geopetal (Prancha 36, foto 2).

Para o topo, continuam a predominar estromatólitos de laminações planas, mas as formas pseudocolunares e colunares que ocorrem esparsas podem apresentar desenvolvimento quase horizontal (cota 768,5 metros). Laminaçöes estromatolíticas milimétricas e gretas de contração são observadas um metro acima, ainda em estromatólitos estratiformes.

$\mathrm{Na}$ cota 770 metros, os estromatólitos estratiformes, apresentam intercalações centimétricas de dolarenitos, constituídos por pequenos clastos imbricados. $O$ dolarenito é um packstone a grainstone, composto por intraclastos micríticos, microfitólitos e bioclastos de estromatólitos; os aloquímicos são mal selecionados, apresentam delgada franja isópaca acicular e pequenas cavidades, originadas por dissolução, preenchidas por calcita espática. Os estromatólitos são constituídos por niveis micríticos, onde se observa pelóides esparsos e laminação fenestral, e por niveis granulares mal selecionados que contêm um pouco de lama.

Na cota 770,5 metros, sobre uma superficie de truncamento, com ondulação ampla, instalaram-se estromatólitos estratiformes de laminação plana a ondulada, com alguns elementos pseudocolunares associados. Petrograficamente, observa-se que os estromatólitos são constituídos por niveis lamosos, que contêm pelóides e raros oóides dispersos. Não foram observadas feições de ressecação, nem laminação fenestral.

Sobre esses estromatólitos, ocorre um nivel decimétrico de dolarenito, constituído essencialmente por bioclastos irregulares, onde ainda se nota material lamoso e restos de filmes orgânicos dispersos (Prancha 37). Observa-se também a presença de bioclastos esféricos, de contorno micrítico, que podem exibir vestígios de silicificaçăo. Esse dolarenito possivelmente representa níveis microbianos, contínuos, e com pouca coesäo, que sofreram desagregação.

Estromatólitos estratiformes, situados acima desse nivel de dolarenito, apresentam pouca laminação fenestral e cristais esparsos de anidrita. Observa-se ainda intercalações granulares mal selecionadas, que são estabilizadas por filmes microbianos e no geral contêm sempre um pouco de lama.

Esses estromatólitos apresentam-se truncados por uma superficie ondulada, sobre a qual se depositaram os packstones com microfitólitos(cota 771 metros), que foram 


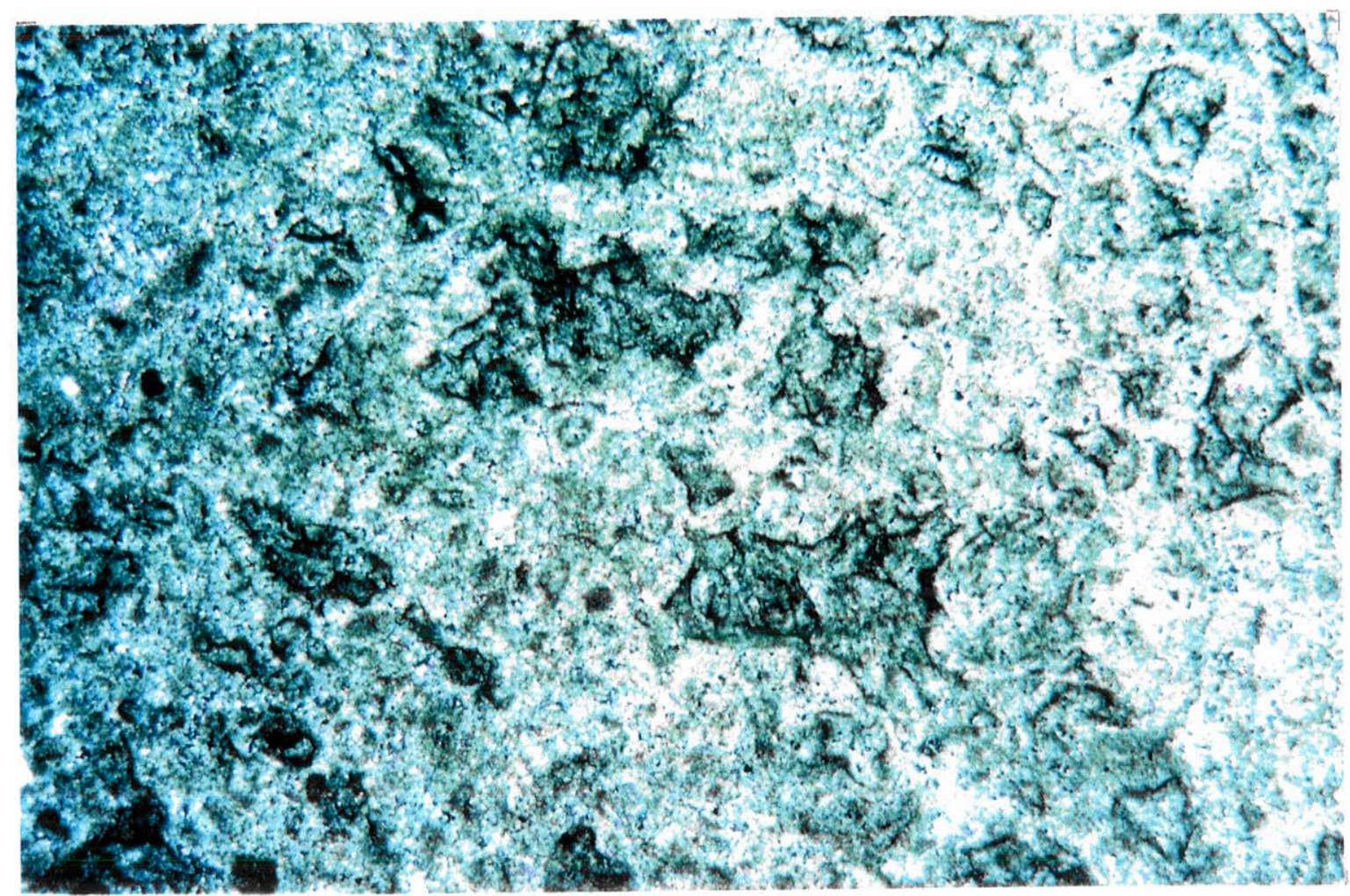

Foto 1 - Fotomicrografia de nível bioconstruído que sofreu desagregação (Fácies DEes) Mina da Bocaina. X.N. 30x

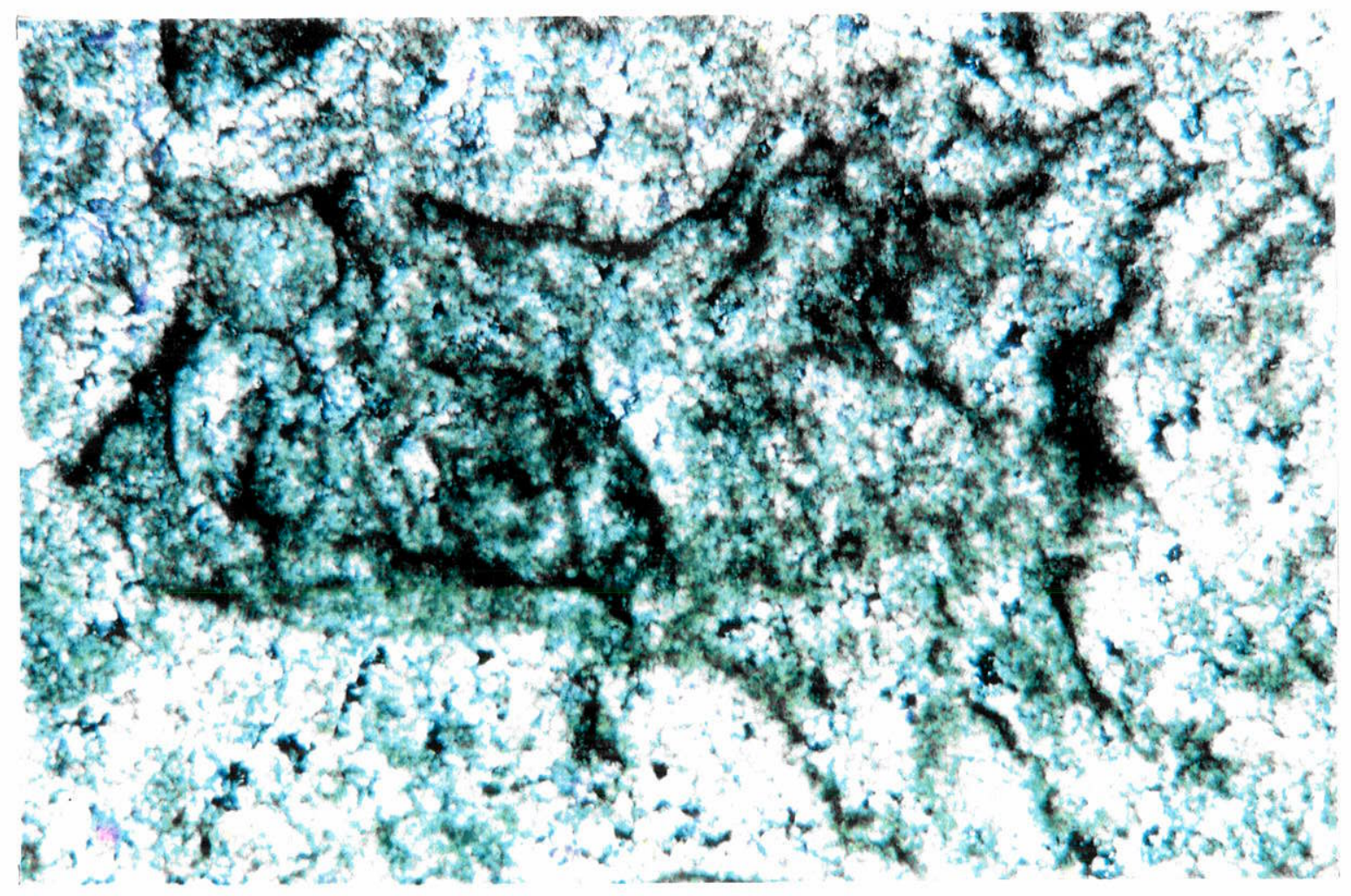

Foto 2 - Fotomicrografia de detalhe da foto anterior, onde se observa restos de filmes orgânicos na matriz. X.N. 100x 
colonizados por estromatólitos estratiformes, os quais näo apresentam laminação fenestral ou evidências de ressecação.

A partir desse nivel, os estromatólitos estratiformes a pseudocolunares de laminação plana a ondulada continuam a ser predominantes, mas não são acessiveis à observação direta.

Próximo ao topo da fácies, parece ocorrer pequenos estromatólitos ramificados e delgados niveis argilosos de cor avermelhada. Lentes de sílex são freqüentes na porção média-superior da fácies, e em lâmina delgada exibem agregados e grãos ooidais, sendo vários deles esferulíticos.

\subsection{3 - Dolomito laminado}

Ocorre na mina em atividade da COMIG (Perfil 4) e tem cerca de 3 metros de espessura. É constituído por um dolomito que apresenta laminações muito variáveis quanto à espessura e pouca regularidade de estruturas sedimentares, tais como laminaçöes cruzadas.

Em lâmina delgada, observa-se que são as laminaçöes representam niveis granulares, packstones, compostos por microfitólitos e pelóides, recobertos por niveis micríticos delgados e contínuos, possivelmente de origem microbiana (Prancha 38).

Obsenva-se aporte cíclico de grãos e de lama carbonática, a qual permanece como pequenas lentes. Não se observou evidências de ressecação.

\subsection{6 - FÁCIES CE: Calcários estromatolíticos}

Foram observados apenas na Mina da Bocaina e ocorrem nos intervalos 3 e 4, sempre instalados sobre uma superficie planar. Os biohermas que ocorrem no Intervalo 4 e os biohermas basais do Intervalo 3 estão instalados sobre calcarenitos intraclásticos (Fácies Cait), em meio aos calcalcarenitos neomorfizados (Fácies Can); Os biohermas de topo do Intervalo 3 estão associados a calcarenitos que apresentam intercalações de calcilutitos (Fácies $\mathrm{CaCl}$ ).

Os biohermas basais do Intervalo 3 constituem corpos estromatolíticos lenticulares, com cerca de um metro e meio de altura e extensão observada de dois metros (Prancha 39 , foto 1). $\mathrm{Na}$ base dos biohermas predominam estromatólitos estratiformes, de laminação ondulada, que gradam a formas pseudocolunares, com alguns elementos colunares e dômicos, decimétricos a centimétricos, associados. As formas colunares são assimétricas, 


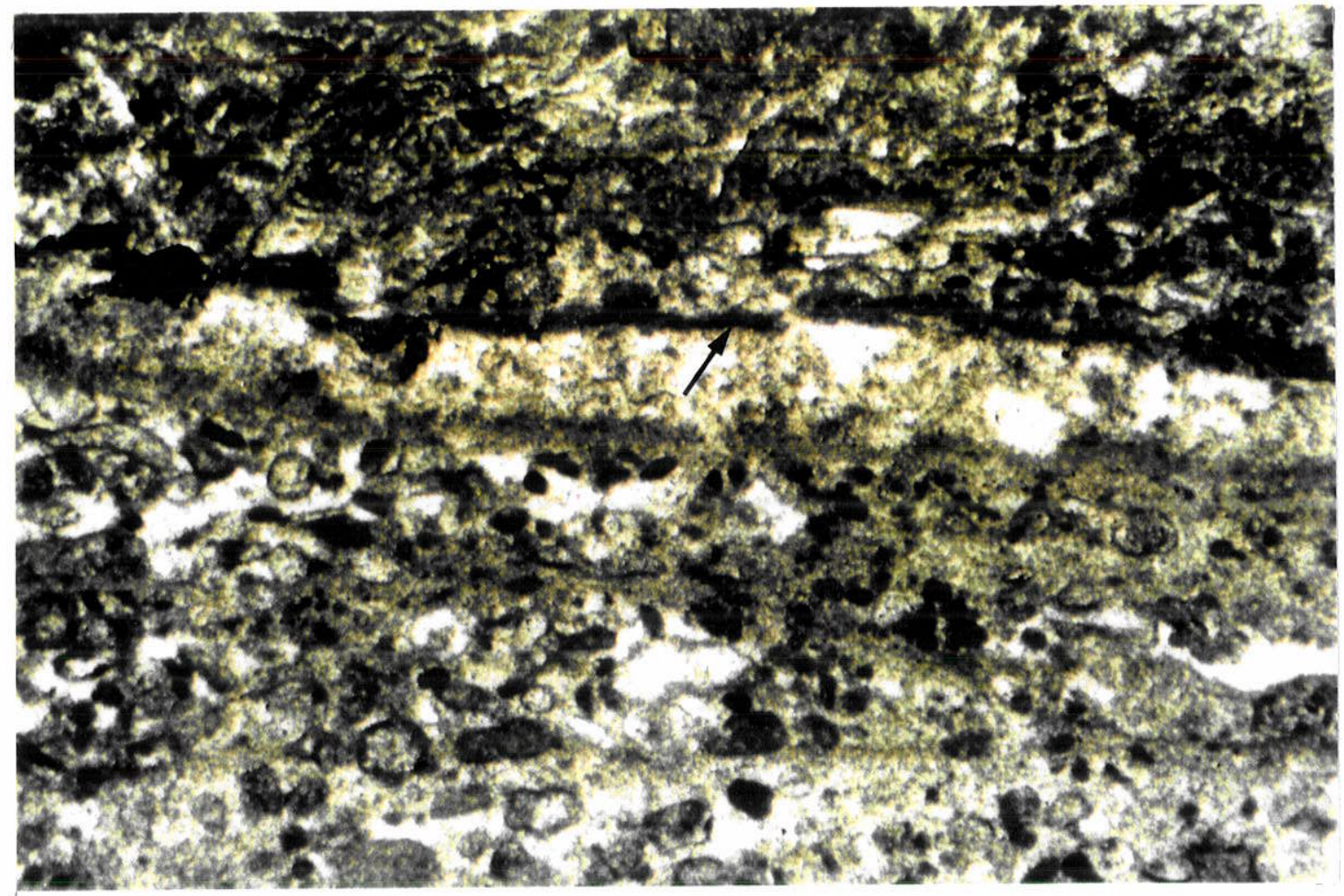

Foto 1 - Fotomicrografia do dolomito laminado que ocorre no Perfil 4, na mina em atividade da COMIG. Observar níveis granulares, packstones, estabilizados por delgados níveis micríticos (seta) P.G./X.N. 25x

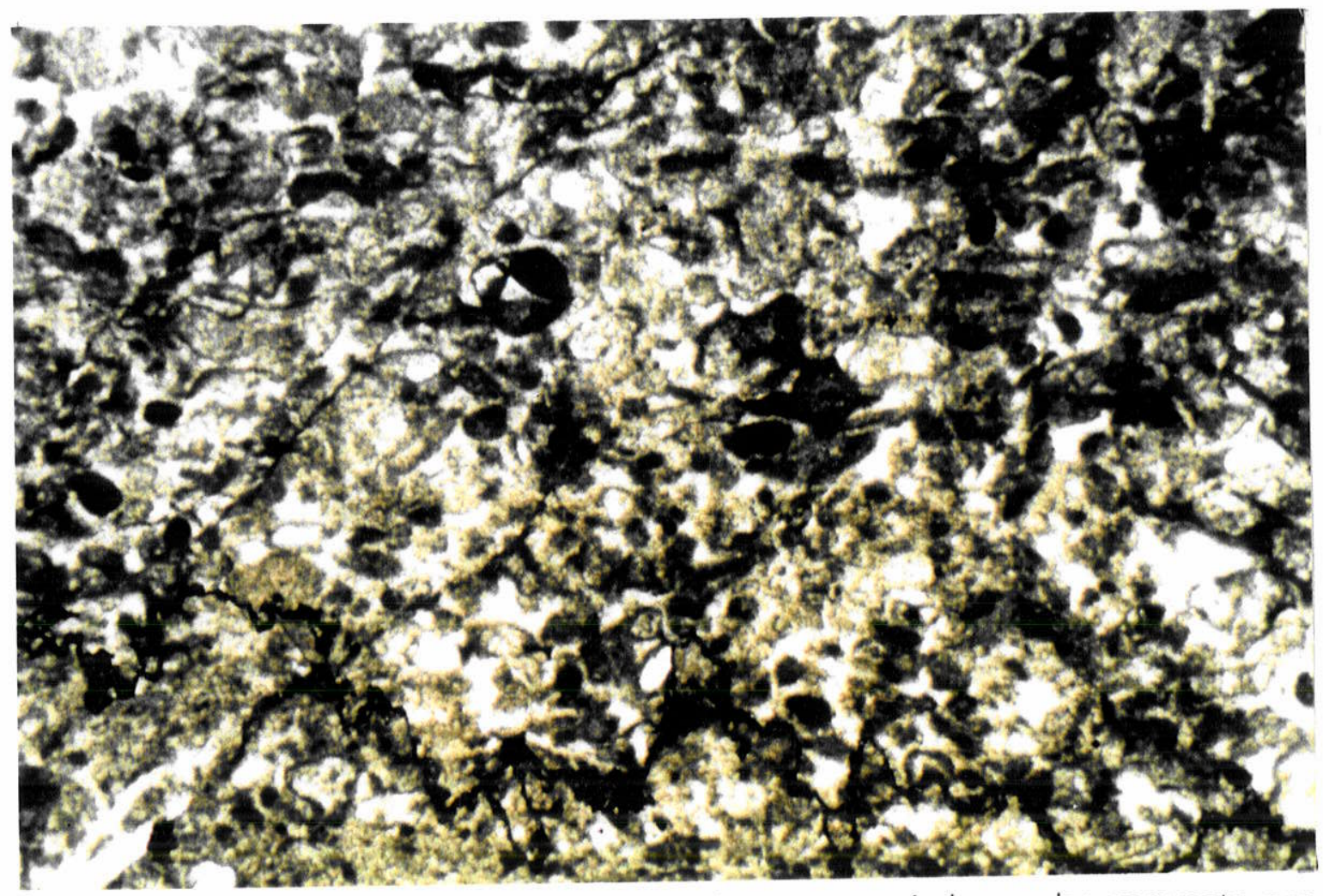

Foto 2 - Detalhe da foto anterior, onde se observa um nível granular composto por microfitólitos e pelóides. X.N. 25x. 


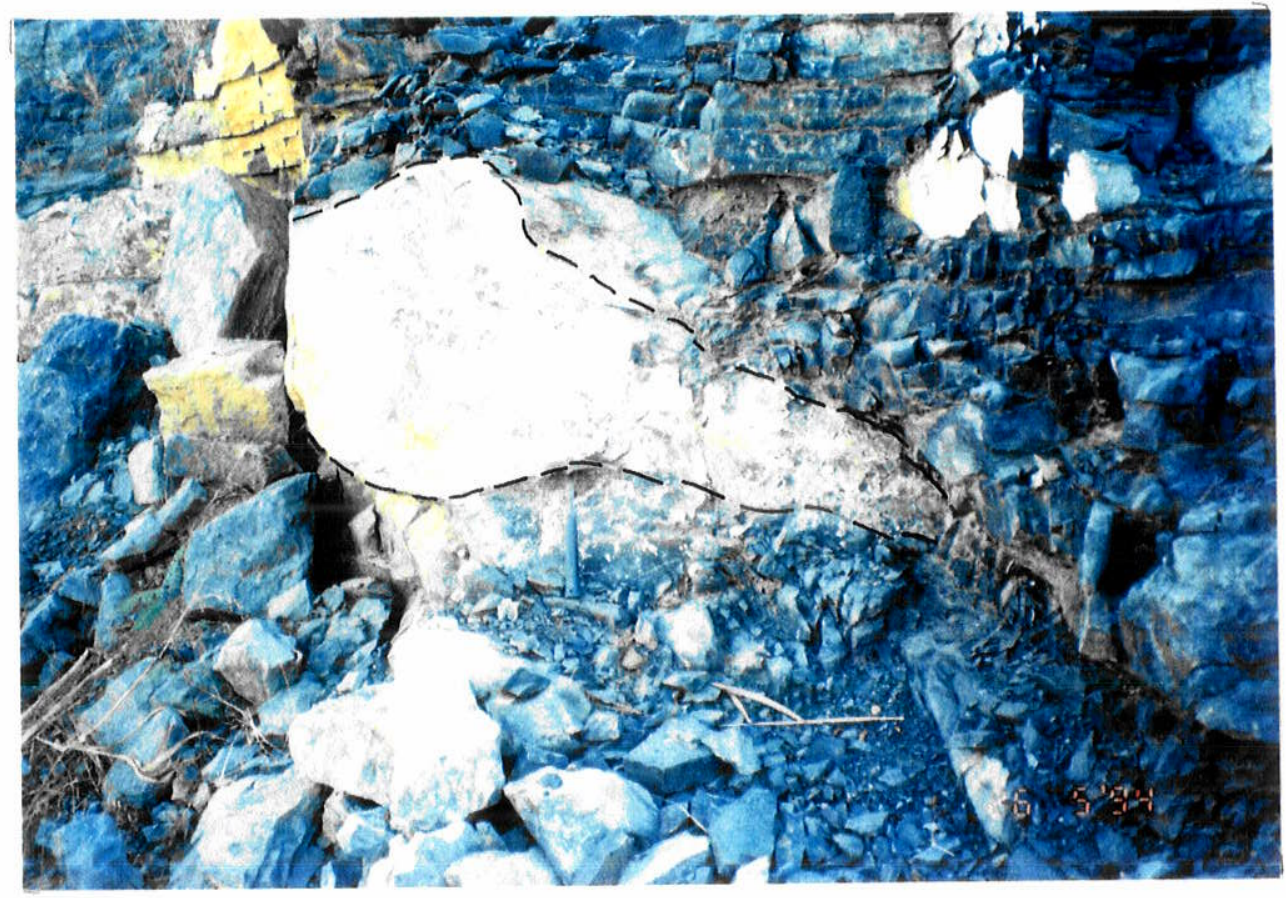

Foto 1 - Bioherma de calcário estromatolítico da Fácies CE, no Intervalo 3, assentado sobre calcarenitos intraclásticos - Fácies Cait. Mina da Bocaina, Perfil 1.

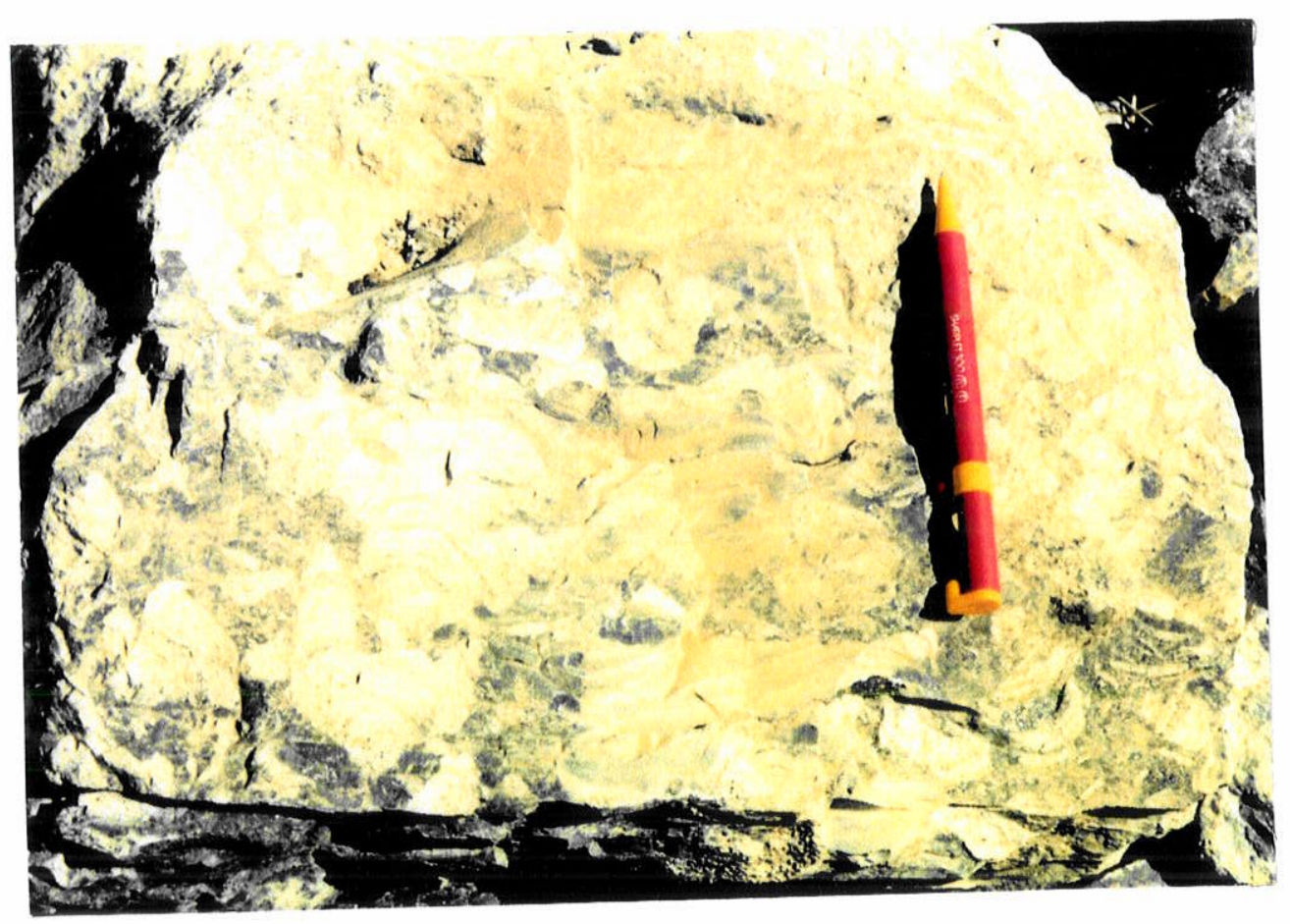

Foto 2 - Bloco rolado, onde se observa fragmentos de estromatólitos junto a estromatólitos ramificados. Perfil 1, Mina da Bocaina. 
e no geral possuem parede lateral e relevo alto, o que indica que cresceram livres dos sedimentos adjacentes. Os estromatólitos dômicos também são ligeiramente assimétricos (Prancha 40).

Em lâmina delgada observa-se que os estromatólitos apresentam níveis construídos, microbianos, de textura grumosa com grãos peloidais esparsos, e niveis granulares, resultantes de aportes externos, cimentados por microespato. Observa-se rara laminação fenestral, com pequenas cavidades.

Em bloco rolado, observou-se pequeno estromatólito colunar ramificado associado à brecha caótica, composta por bioclastos de estromatólitos.

Os biohermas que ocorrem associados aos carbonatos da Fácies $\mathrm{CaCl}$ são métricos (cerca de um metro de altura e mais de dois metros de comprimento), apresentam espaçamento médio de um metro, e se tornam progressivamente menores (10 centímetros de altura e 30 centímetros de comprimento em média) e mais escassos em direção ao topo da fácies (Prancha 41).

Os biohermas que ocorrem na parte basal da Fácies $\mathrm{CaCl}$ são compostos por estromatólitos pseudocolunares, com raros elementos colunares associados, formando uma massa compacta (Prancha 41, foto 2) e apresentam-se inteiramente recobertos por lama carbonática de cor avermelhada. Estão fortemente neomorfizados, mas em lâmina delgada ainda se observa lâminas micríticas que contém filmes escuros, delgadas lentes ou niveis lamosos e bolsões ou niveis granulares compostos por pelóides (Prancha 42). Os pequenos biohermas de topo são constituidos por estromatólitos estratiformes, de laminação plana a ondulada. Muito raramente ocorrem elementos colunares, que não apresentam parede lateral, o que sugere que não apresentavam relevo em relação aos sedimentos adjacentes (Prancha 41, foto 1).

Os biohermas estromatolíticos presentes no Intervalo 4 têm cerca de dois metros e meio de altura e três metros de extensão observada, e são constituidos por estromatólitos predominantemente pseudocolunares, com formas dômicas e colunares associadas (Prancha 43).

Em lâmina delgada, observa-se pequenos estromatólitos colunares que apresentam conexões entre as colunas. A microestrutura é difusa (Hofmann 1969), pode-se reconhecer as laminações, mas seus limites não são nítidos (Prancha 44). No espaço intercolunar ocorrem bioclastos escuros, micríticos, ou de contorno micrítico, que constituem um grainstone a microfitólitos. Não se observou a presença de material lamoso nas laminações estromatolíticas, nem no material contido no espaço intercolunar. 

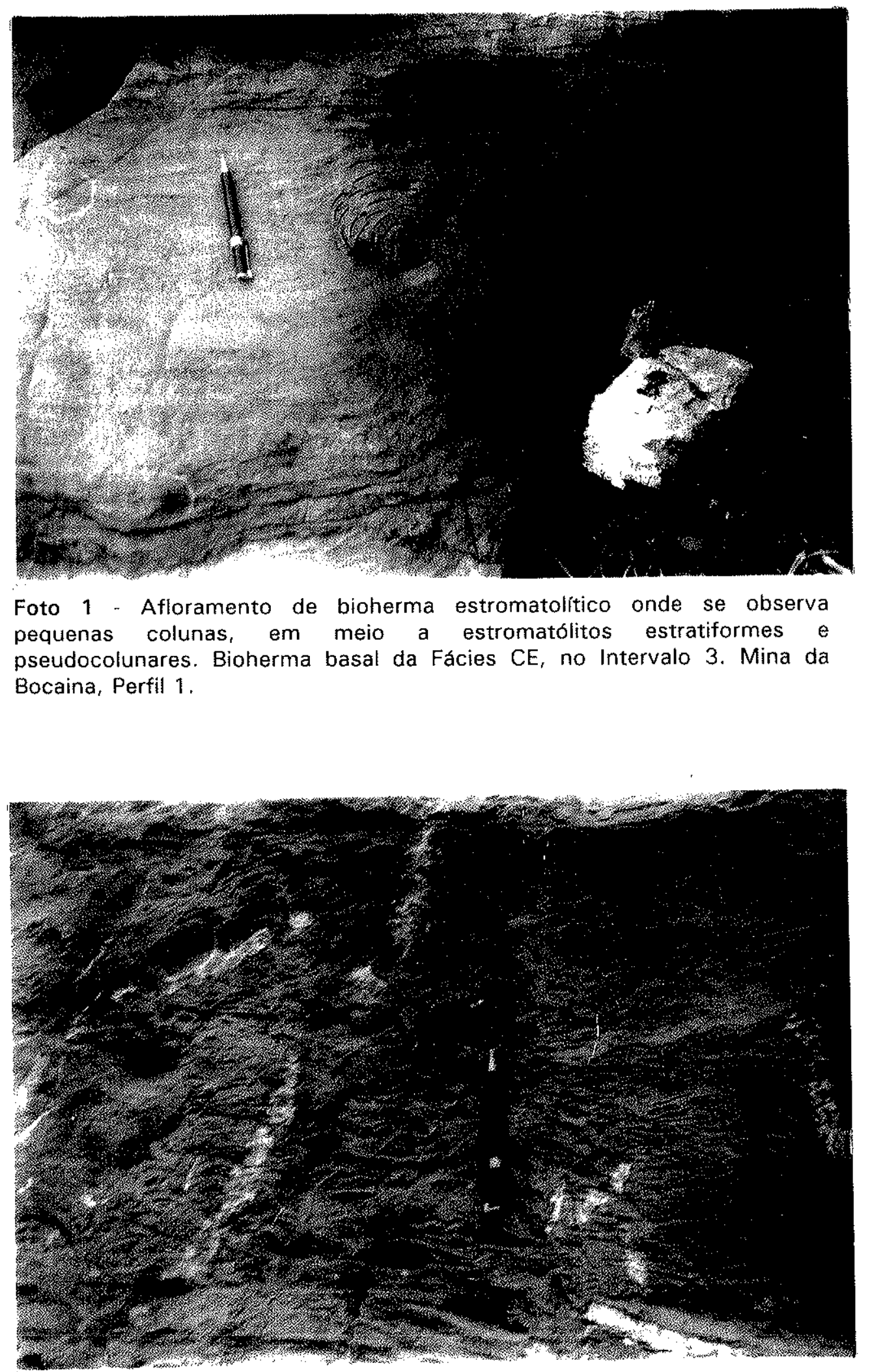

Foto 2 - Detalhe do bioherma estromatolítico da foto anterior, onde se nota formas colunares associadas a estromatólitos pseudocolunares. 


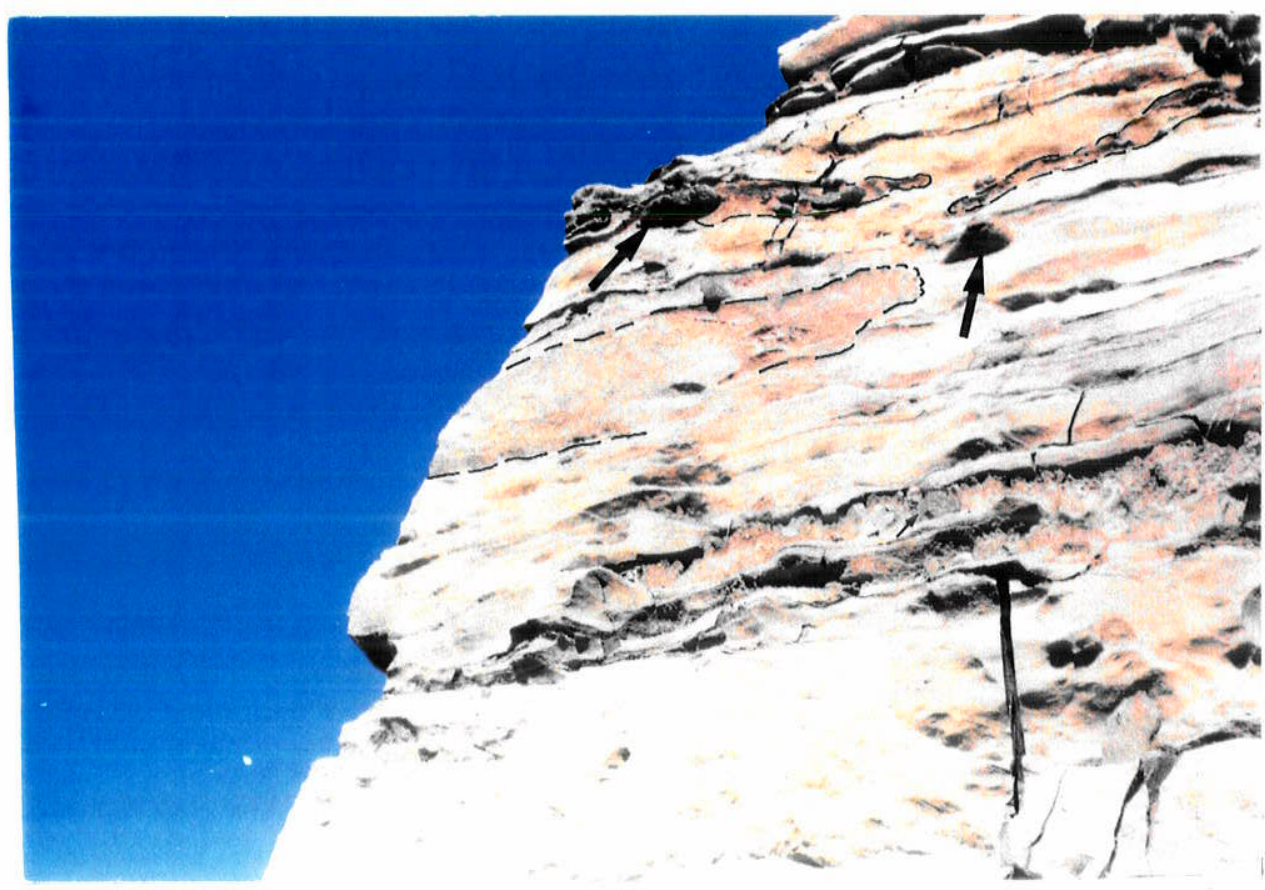

Foto 1 - Pequenos biohermas de calcário estromatolítico, eventualmente associados a lentes de sílex (seta). Os estromatólitos são predominamente estratiformes, com raras formas colunares. Mina da Bocaina, Fácies CE, Intervalo 3.

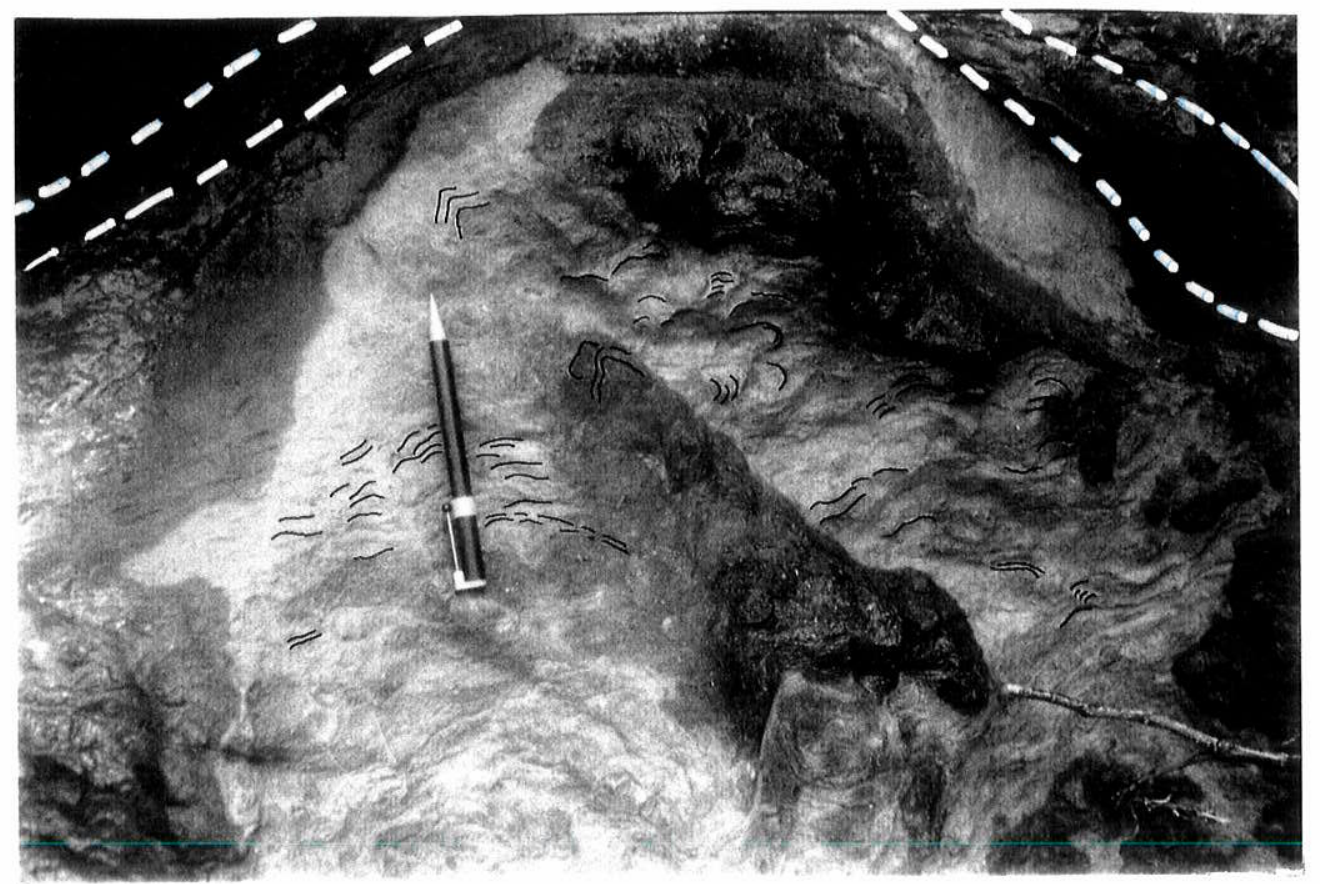

Foto 2 - Bioherma estromatolítico com formas pseudocolunares a colunares. Assenta-se sobre o nível de calcirrudito associado à Fácies Caoo, Intervalo 3, e foi totalmente recoberto por material lamoso. Fácies CE. Mina da Bocaina. 


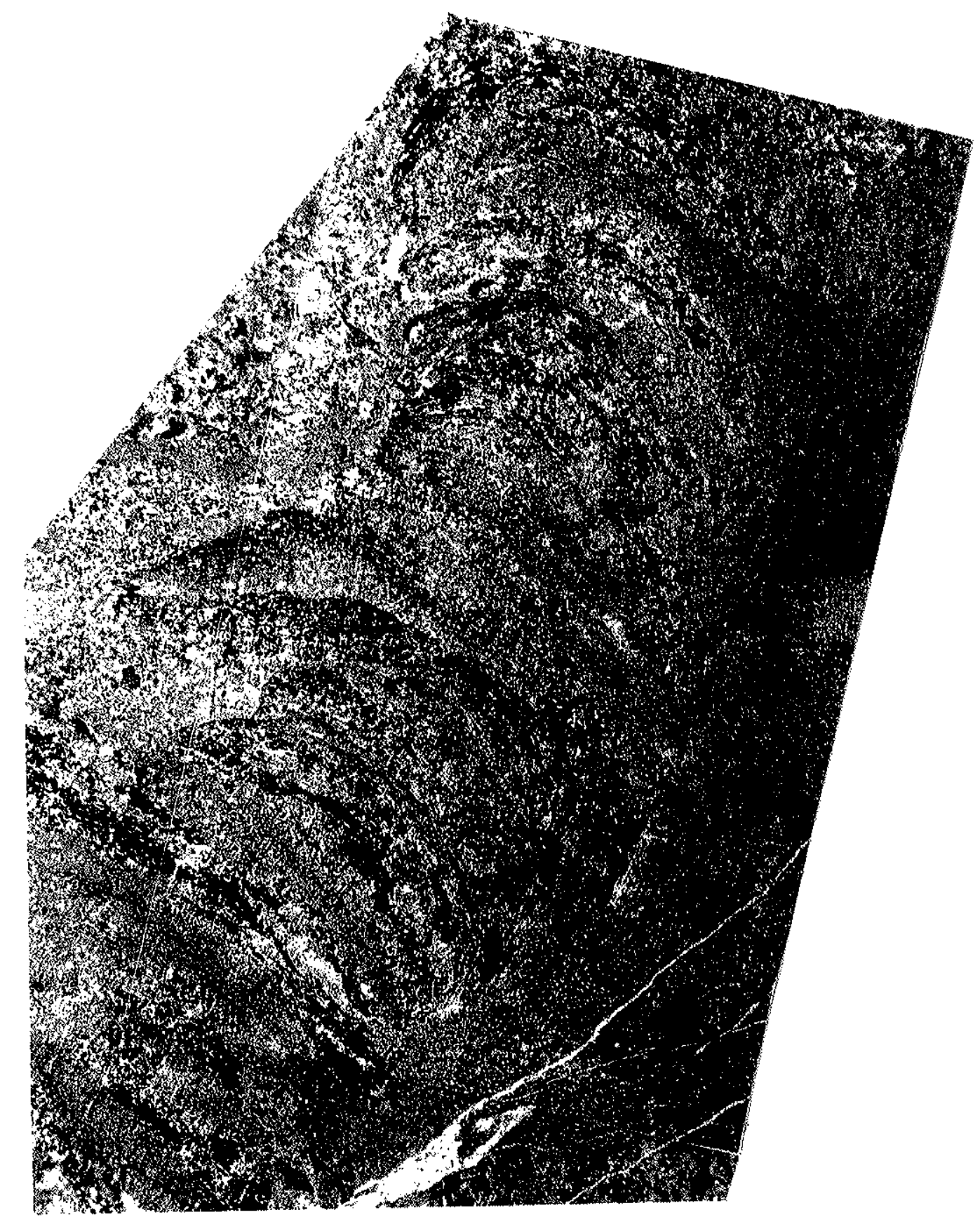

Fotomicrografia composta de pequena coluna estromatolitica da Fácies CE, muito neomorfizada. Observa-se ainda alguns filmes micríticos, e material granular lateralmente ao estromatólito. Perfil 1, Mina da Bocaina L.N. $5 x$ 


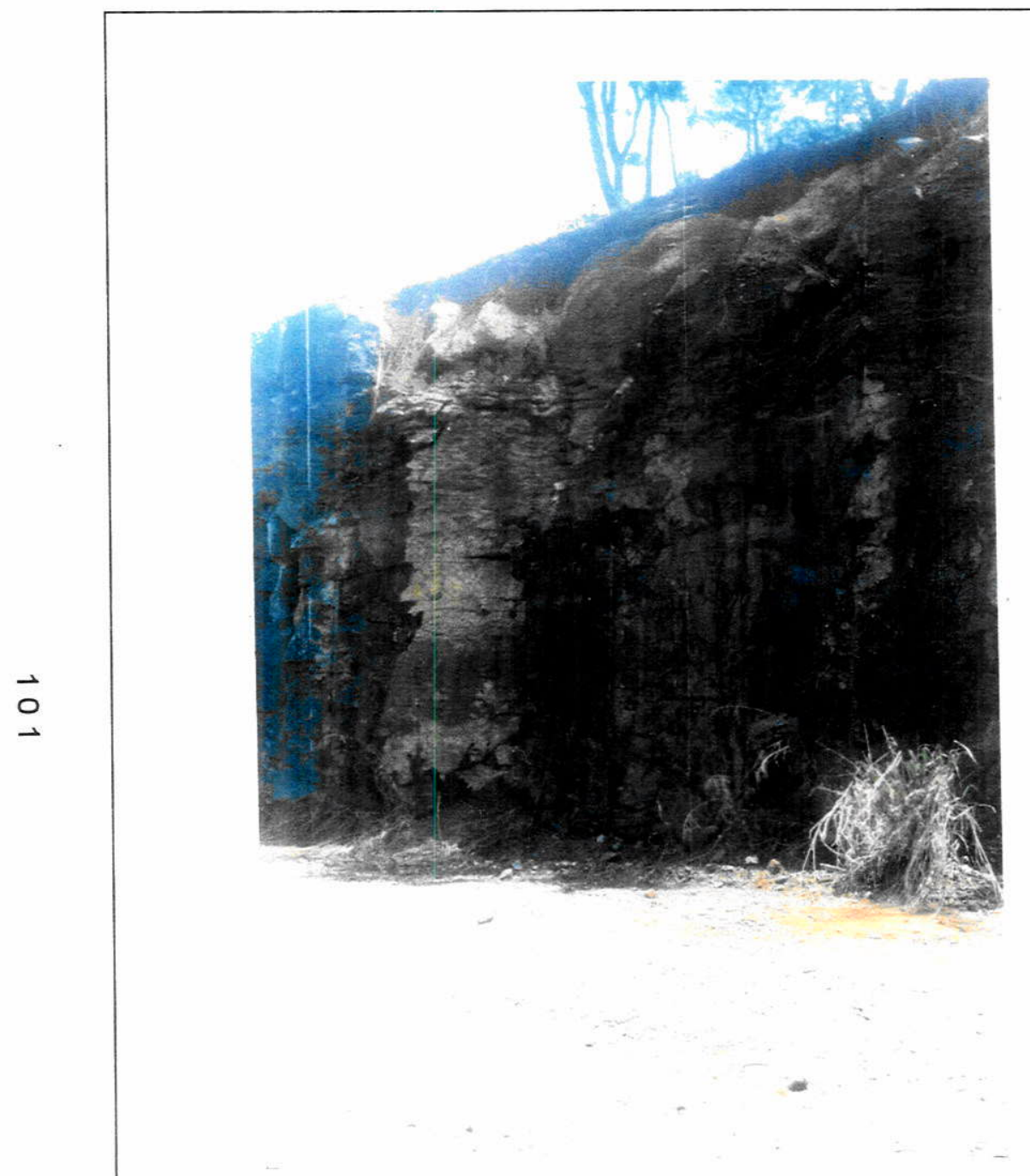

Foto 1 - Vista geral das fácies que afloram no topo da Mina da Bocaina, Perfil 1 (Intervalo 4) com cerca de 15 metros de altura.

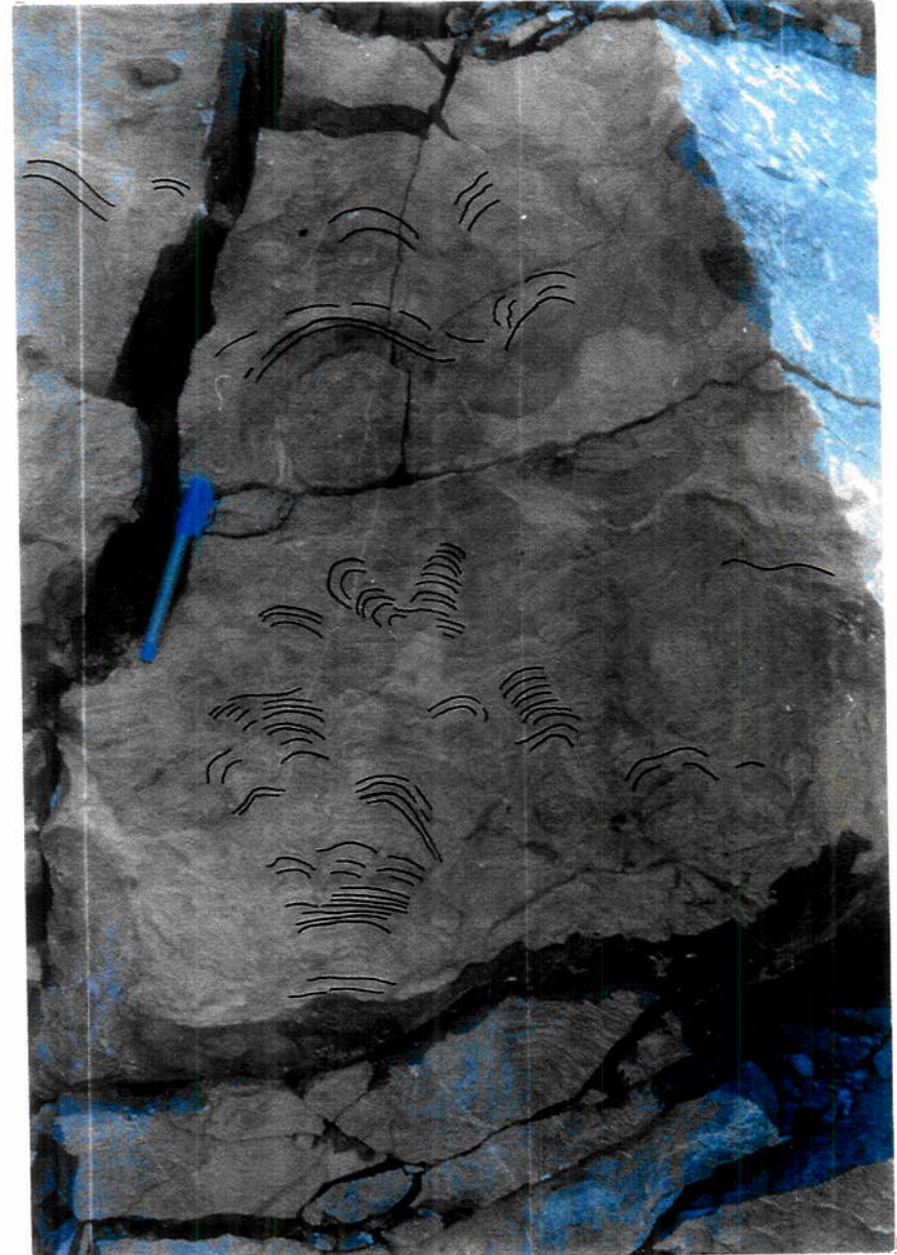

Foto 2 - Bloco rolado de bioherma estromatolítico composto por elementos pseudocolunares a colunares. Fácies CE, Intervalo 4. Mina da Bocaina. 


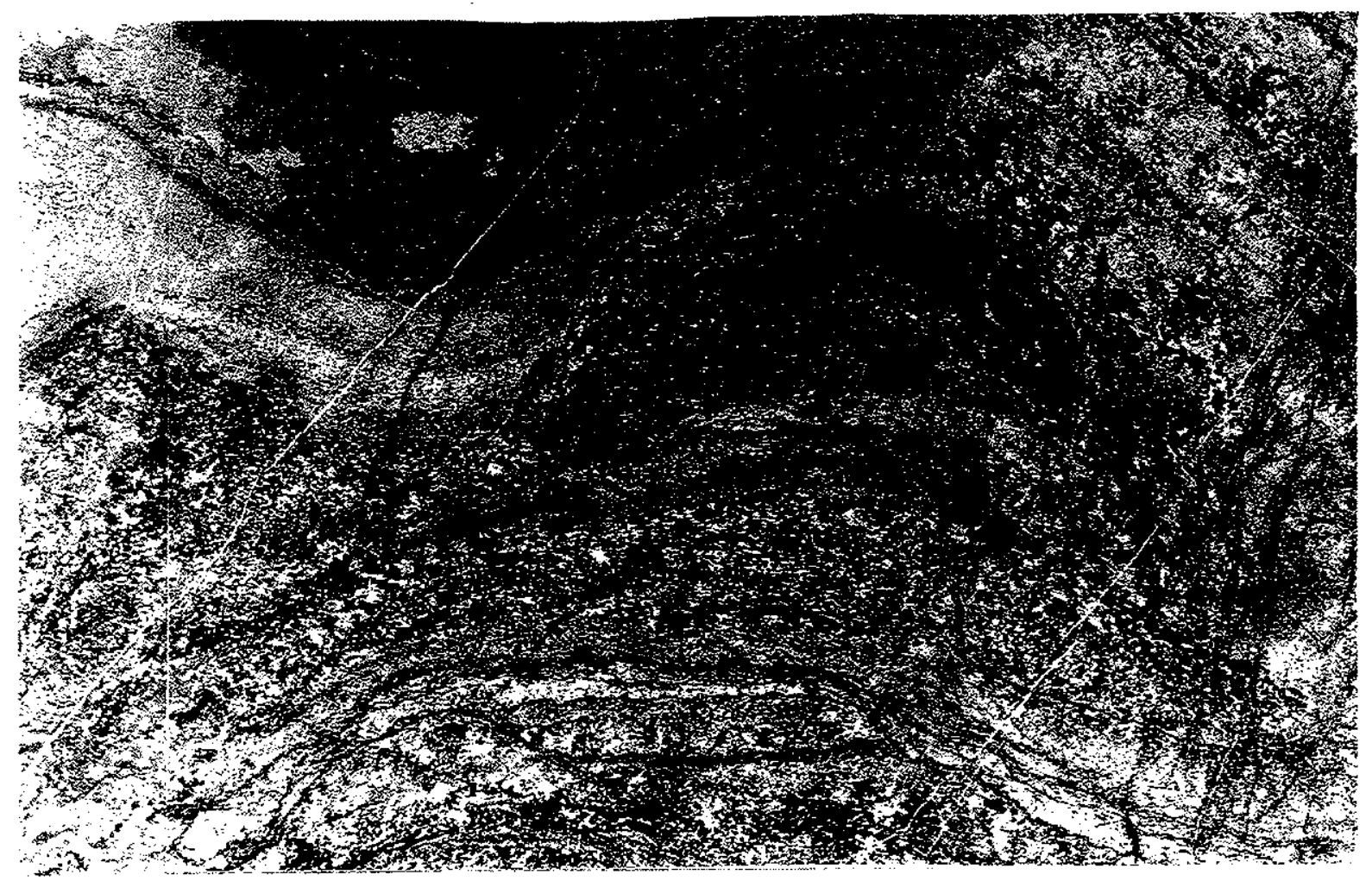

Fotomicrografia composta de estromatólito da Fácies CE, Intervalo 4 , onde pequena coluna estromatolítica apresenta lâminas cuja microestrutura é caracterizada por microfábrica difusa, sem limites nítidos, e está recristalizada. Lateralmente às colunas observa-se grainstone composto por microfitólitos. Perfil 1, Mina da Bocaina. L.N. $5 x$ 


\subsection{7 - FÁCIES Cait: Calcarenitos intraclásticos}

Ocorrem nos intervalos 3 e 4 e foram observados no Perfil 1, na Mina da Bocaina. São de cor cinza escuro, mal selecionados e compostos por clastos de grande diversidade textural, embora todos sejam carbonáticos. No geral estão fortemente neomorfizados e salvo em niveis silicificados, pouco se pode observar. Mas como petrograficamente foi possivel identificar algumas características importantes, não foram incluídos nos calcarenitos neomorfizados (Fácies Can).

Macroscopicamente, observa-se que os calcarenitos intraclásticos constituem niveis decimétricos que se adelgaçam para o topo, quando apresentam um delgado horizonte planar, levemente ondulado e de aspecto maciço. Sobre esse nivel se instalam biohermas estromatolíticos da Fácies CE.

No Intervalo 3, o calcarenito intraclástico é constituído por camadas centimétricas a decimétricas de granulaçōes contrastantes, média e grossa a muito grossa; alguns níveis (centimétricos) de calcarenito grosso a muito grosso estão parcial ou totalmente silicificados (Prancha 45). Os calcarenitos apresentam laminaçöes cruzadas por ondas (menores nos calcarenitos mais finos) e são truncadas por ondulaçōes não paralelas, que em perfil, apresentam comprimento de onda de cerca de 50 centímetros. Granodecrescência ascendente é observada nos niveis de granulação mais grossa.

Para o topo da fácies ocorre adelgaçamento das camadas e observam-se laminaçöes cruzadas por onda de baixo ângulo a plano-paralelas, que são truncadas por ondulações amplas e de muito baixa amplitude.

Petrograficamente, os calcarenitos de granulação grossa, silicificados, constituem packstones a grainstones compostos por oóides, agregados, fragmentos de calcarenito oolítico, pelóides e raros microfitólitos, bem arredondados, predominantemente ovalados a irregulares, eventualmente botrioidais (Prancha 46). Alguns aloquímicos são quase negros por apresentarem grande quantidade de pirita disseminada.

As feições originais dos niveis de calcarenito não silicificado encontram-se pouco preservados. Observa-se vestígios de aloquímicos de granulação areia média, e grãos esparsos, de granulação areia grossa a muito grossa, semelhante a agregados, com algumas capas concêntricas, fortemente deformados, em matriz lamosa.

Os calcarenitos intraclásticos que ocorrem no Intervalo 4 são muito semelhantes aos observados no Intervalo 3. Na base apresentam niveis decimétricos de calcário maciço, escuro, com ondulaçöes locais de grande amplitude, possivelmente de origem tectônica, 


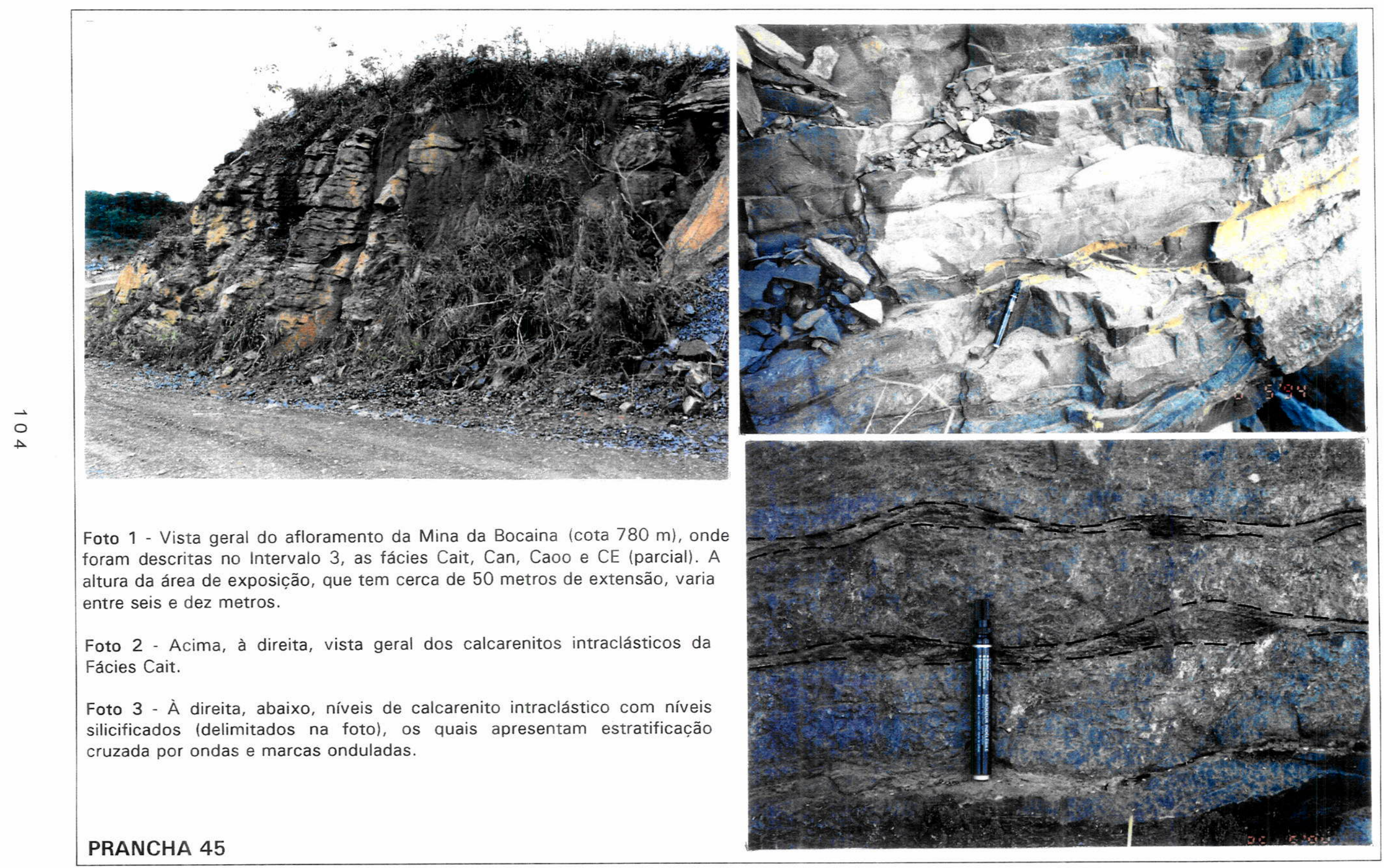




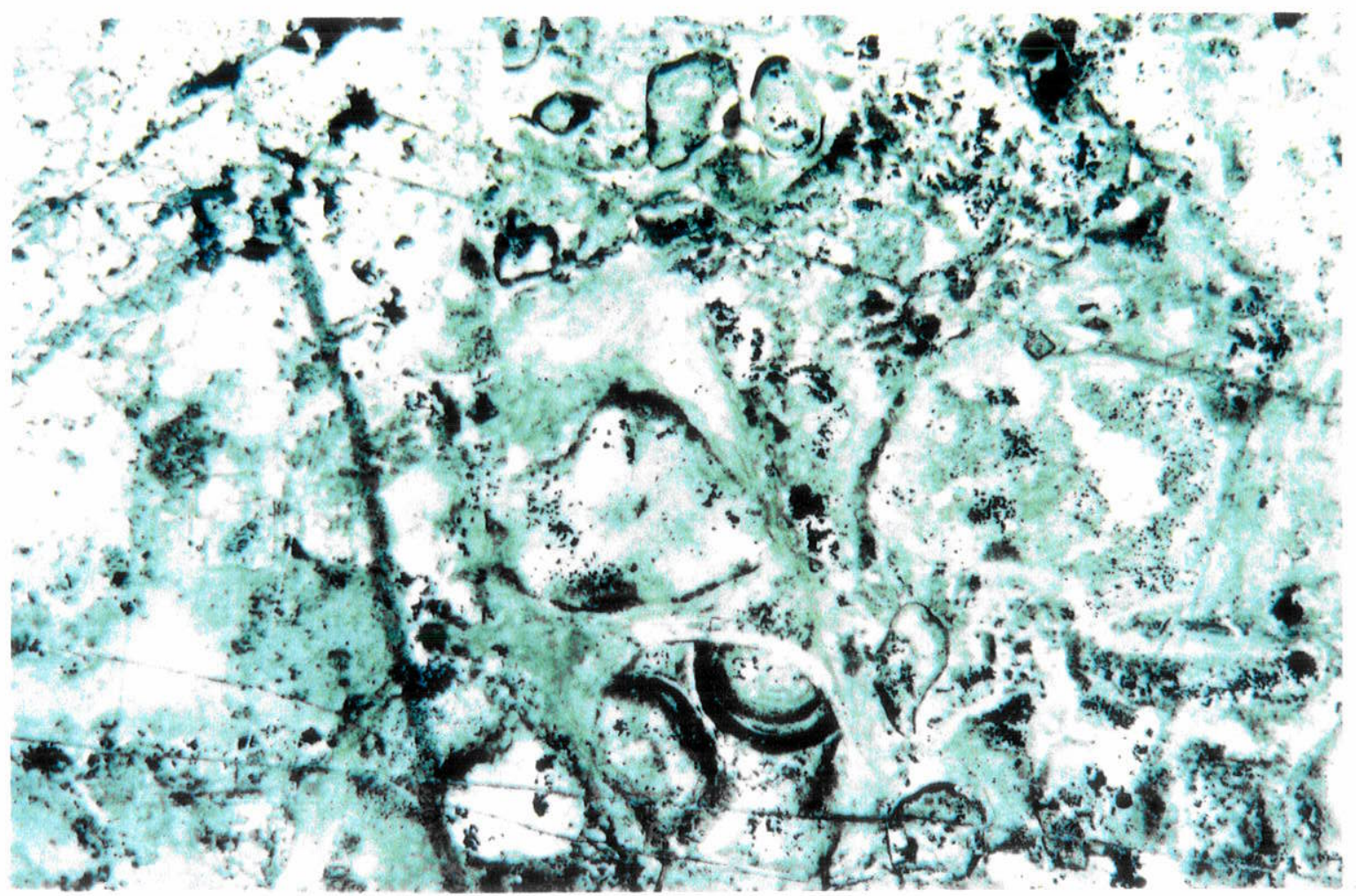

Foto 1 - Fotomicrografia de calcarenito intraclástico silicificado (Fácies Cait) do Intervalo 3. Observar intraclasto composto por oólitos. Perfil 1, Mina da Bocaina. L.N. 60x

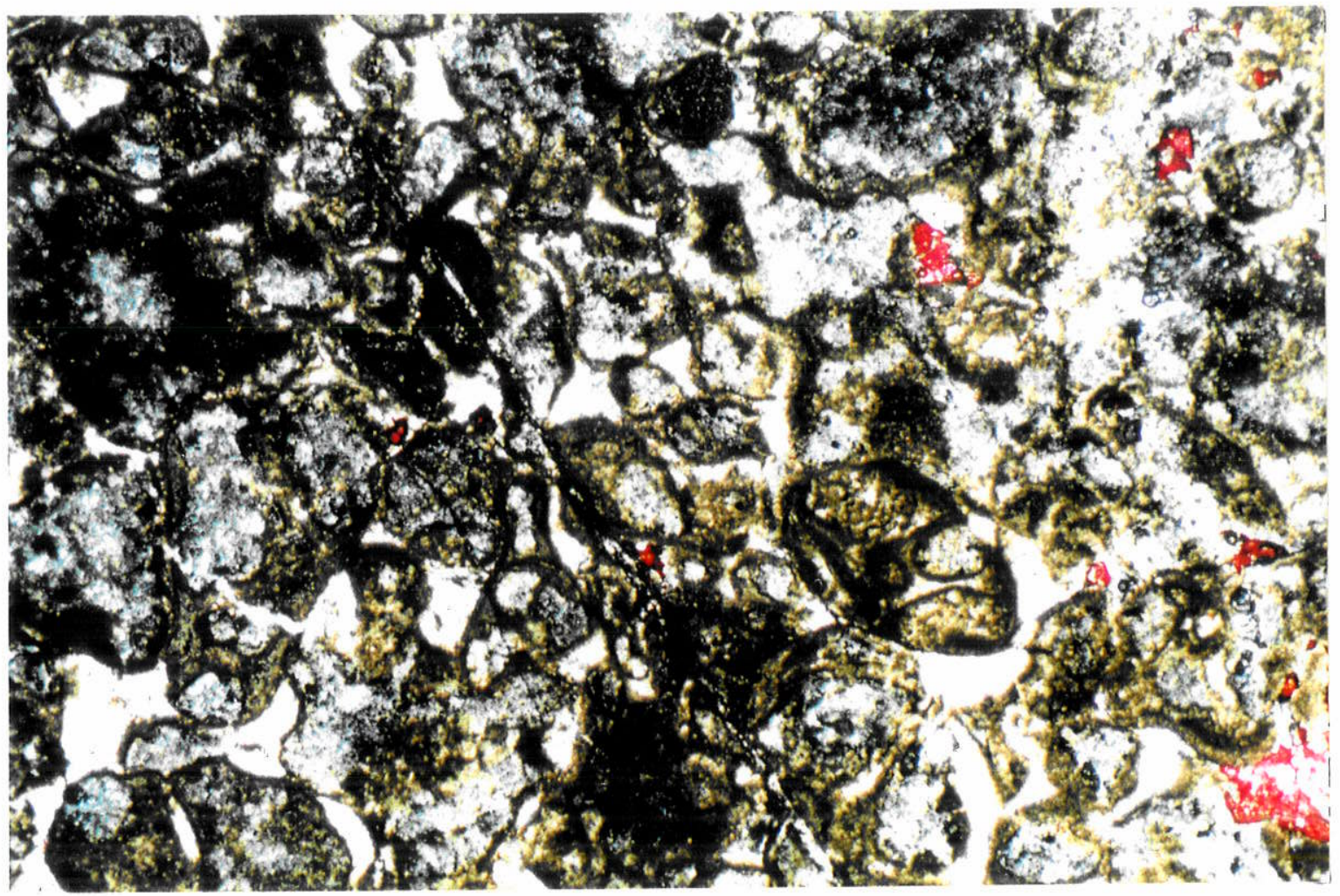

Foto 2 - Fotomicrografia de calcarenito intraclástico da Fácies Cait, no Intervalo 3. Observar silicificação parcial dos clastos. Mina da Bocaina. P.G./X.N. 30x 
pois a área é afetada por falhamento transcorrente. Como no intervalo precedente, as camadas tornam-se gradativamente mais delgadas em direção ao topo da fácies.

Petrograficamente, observa-se, na maioria das vezes, apenas vestígios de aloquímicos em mosaico de pseudoespato. Mas em algumas lâminas é possivel observar um calcarenito de arcabouço aberto, composto por grãos texturalmente heterogêneos, de cor escura, onde predominam agregados, fragmentos de calcarenito oolítico, intraclastos micríticos, oólitos, fragmentos de oólitos e oóides, constituindo um grainstone intraclástico (Prancha 47). Os aloquímicos são mal selecionados, com a granulação variando de areia fina a grânulos; são irregulares a ovalados quanto à forma, subarredondados a arredondados; em alguns aloquímicos é possível observar vestígios de franja isópaca, talvez originalmente aragonítica que sofreu inversão para calcita e silicificação incipiente. Vários grãos apresentam-se fraturados, após a deposição do cimento em franja isópaca. É comum a presença de cristais de pirita disseminada nos grãos.

\subsection{8 - FÁCIES Caoo: Calcarenitos oolíticos}

Os calcarenitos oolíticos foram observados no Perfil 1, na Mina da Bocaina. Ocorrem frequentemente nos intervalos 3 e 4, e não foram observados no Intervalo 2; no Intervalo 1 , os dolarenitos ooidais poderiam representar calcarenitos oolíticos que foram dolomitizados.

No Intervalo 3, os calcarenitos oolíticos constituem um pacote de cerca de dois metros e meio de espessura, em contato nítido e ondulado com a litologia subjacente (Fácies Can). Apresentam estratificação cruzada por ondas que são truncadas por ondulaçōes decimétricas. $\mathrm{Na}$ base da fácies, as estratificaçōes cruzadas por ondas são maiores e eventualmente podem compor pequenos ciclos, onde estratificações cruzadas gradam a marcas onduladas e a laminaçōes plano-paralelas. Para 0 topo as estratificaçōes cruzadas por ondas são menores, as marcas onduladas são suaves e 0 calcarenito oolítico contém delgadas lentes de material fino intercalado.

Petrograficamente, observa-se que os oólitos são esféricos ou ovalados, heterogêneos, frequentemente micríticos, às vezes sem capas concêntricas observáveis. Alguns oólitos são bem formados, com capas nítidas, enquanto outros são superficiais; podem ter o núcleo constituído por vários fragmentos aglutinados ou não apresentar núcleo individualizado, eventuaimente com estrutura radial, sendo semelhantes a esferulitos, mas sem cruz negra sob nicóis cruzados. Certos grãos lembram oncólitos, com os envoltórios apresentando descontinuidades e irregularidades internas; ocorrem 


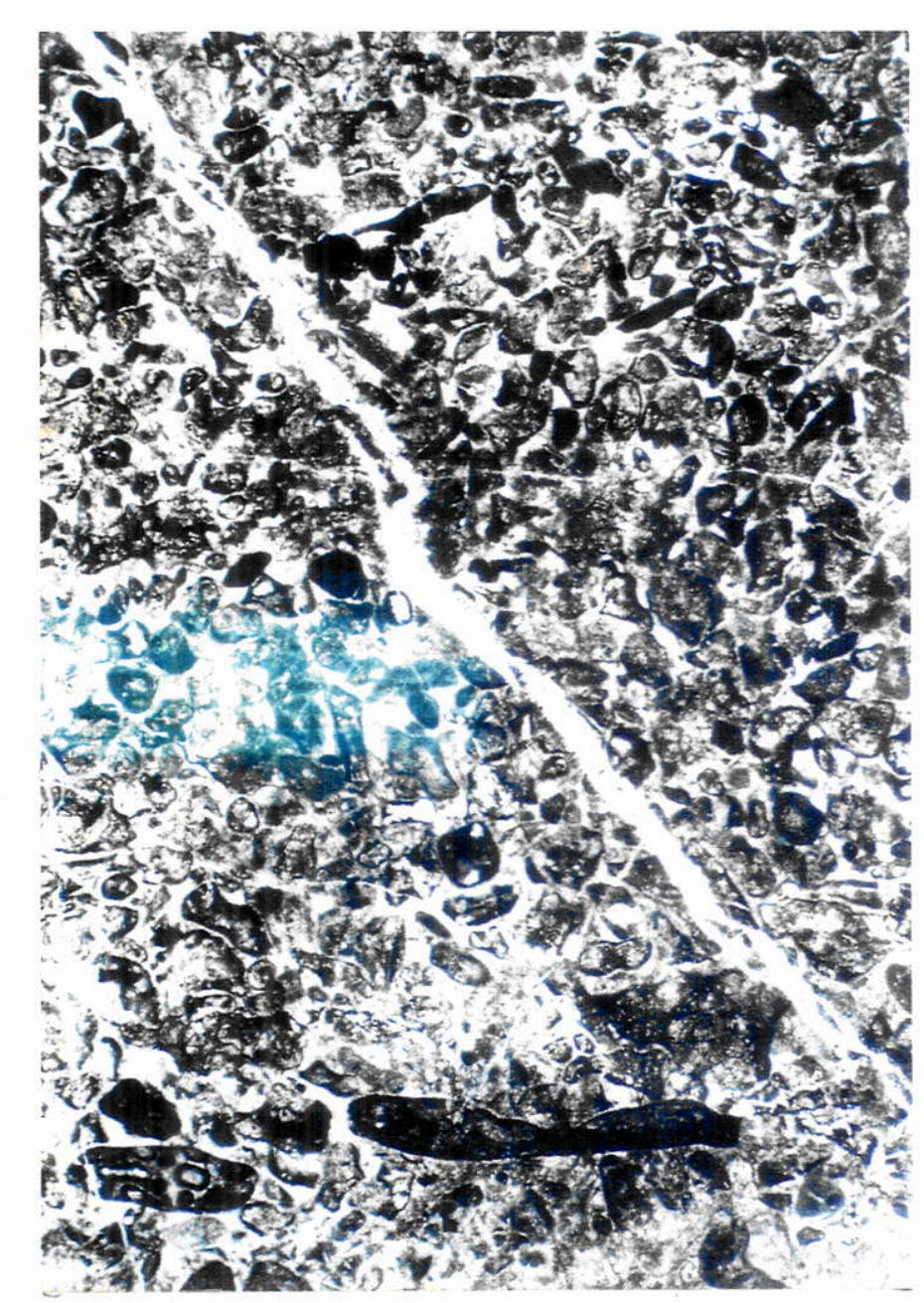

Foto 1 - Fotomicrografia de calcarenito intraclástico da Fácies Cait, onde se observa clastos escuros, que estão parcialmente silicificados. Intervalo 4. Mina da Bocaina, Perfil 1. L.N. 10x

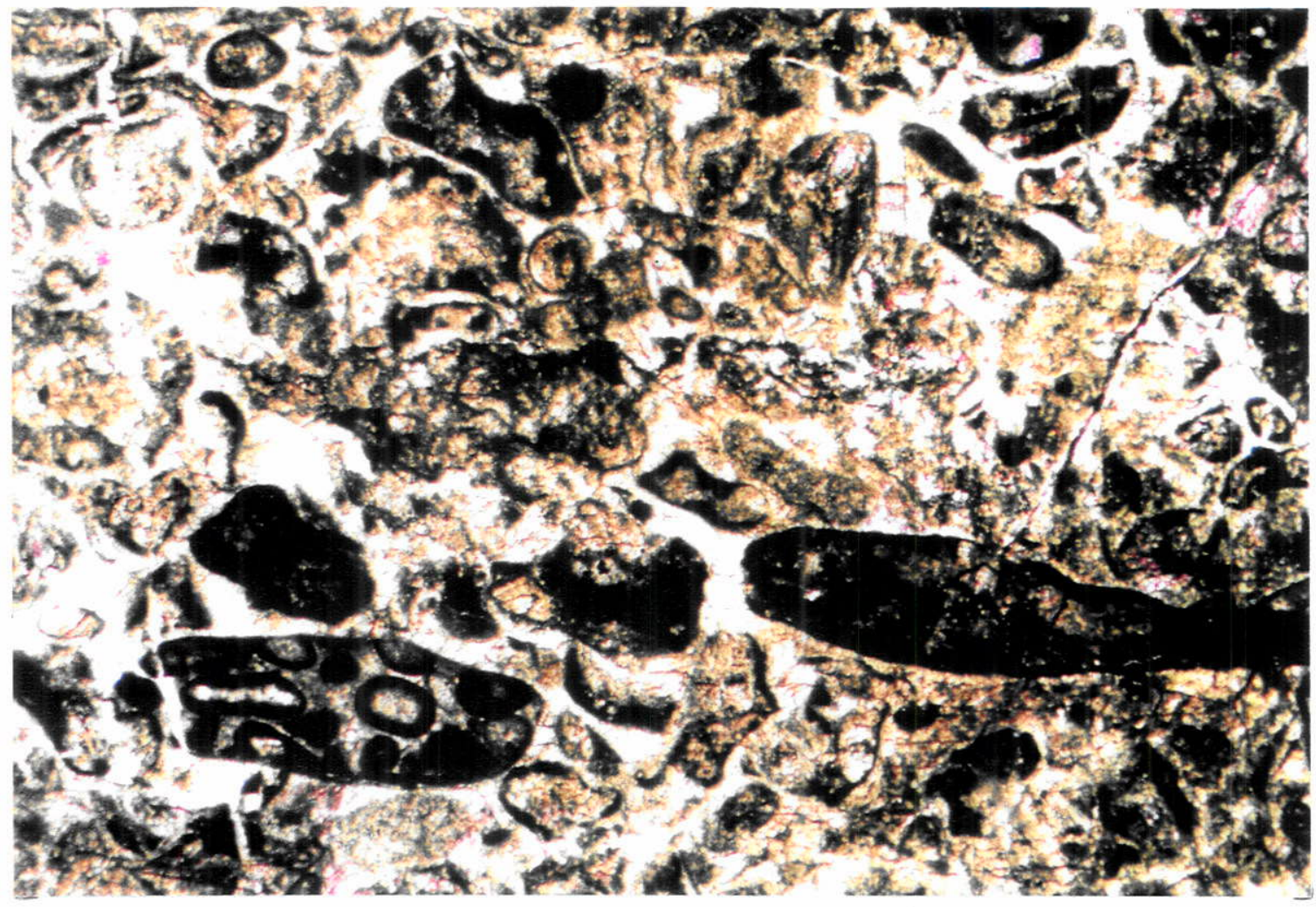

Foto 2 - Fotomicrografia de detalhe da parte inferior da foto 1, onde se observa intraclastos de calcarenito oolítico, entre outros fortemente neomorfizados. P.G./X.N. $25 x$ 
predominantemente associados a oólitos micríticos. Na maioria das vezes, devido ao neomorfismo, os oólitos guardam apenas vestígios das capas concêntricas originais; podem eventualmente apresentar o centro e/ou algumas capas substituídas por sílex (Prancha 48, foto 1).

Texturalmente, os calcarenitos oolíticos variam de grainstone a packstone e são de granulação grossa a muito grossa; o grau de seleção é melhor na base que no topo do pacote. Franja isópaca acicular pode ser observada ao redor de oólitos, que podem apresentar cristais esparsos de pirita. Associados aos oólitos podem ocorrer aloquímicos de granulação areia média a fina, que no geral estão muito neomorfizados e são dificeis de serem definidos. São arredondados a bem arredondados, ovalados esféricos ou irregulares; alguns sugerem oólitos, pois apresentam vestígios de delgadas capas concêntricas, mas outros não.

Freqüentemente, o calcarenito oolítico apresenta deformação, no geral, paralela ao acamamento; os grãos micríticos estão mais deformados, com desenvolvimento de textura semelhante à espastolítica (Prancha 48, foto 2), enquanto os oólitos com vestígios de capas concêntricas são mais afetados por quebramento.

Sobre o calcarenito oolítico assenta-se um nivel de calcirrudito (cerca de 30 centimetros de espessura), com contato basal nítido e planar. Constitui um conglomerado sustentado pela matriz, com gradação normal, e tem no topo pequenas marcas onduladas que gradam a laminação ondulada a plano-paralela. $\mathrm{Na}$ base ocorrem clastos lamelares, centimétricos, subangulares a arredondados, de calcilutitos ou de calcarenito com estratificação cruzada, que podem estar encurvados. Texturalmente, a matriz do conglomerado é um grainstone bimodal, de arcabouço aberto e composto por oólitos de granulação grossa a muito grossa e grãos neomorfizados, alguns possívelmente oolíticos, ovalados a irregulares quanto à forma, bem arredondados, de granulação areia fina a muito fina (Prancha 49, foto 1). Filmes micriticos, possivelmente de origem microbiana, estabilizam os sedimentos de topo do calcirrudito (Prancha 49, foto 2). Acima desse nivel estabelecem-se os biohermas estromatolíticos basais relacionados à Fácies $\mathrm{CaCl}$.

Os calcarenitos oolíticos que ocorrem no Intervalo 4, apresentam cerca de três metros e meio de espessura e possuem características algo diferentes das observadas no Intervalo 3. Na parte basal da fácies, os calcarenitos oolíticos apresentam estratificação cruzada por ondas de baixo ângulo e ondulaçöes amplas. Como se trata de uma região afetada por falhamentos, as ondulações podem näo corresponder a marcas onduladas, mas serem de origem tectônica (Prancha 50). Observam-se nesse pacote lentes decimétricas de silex. 


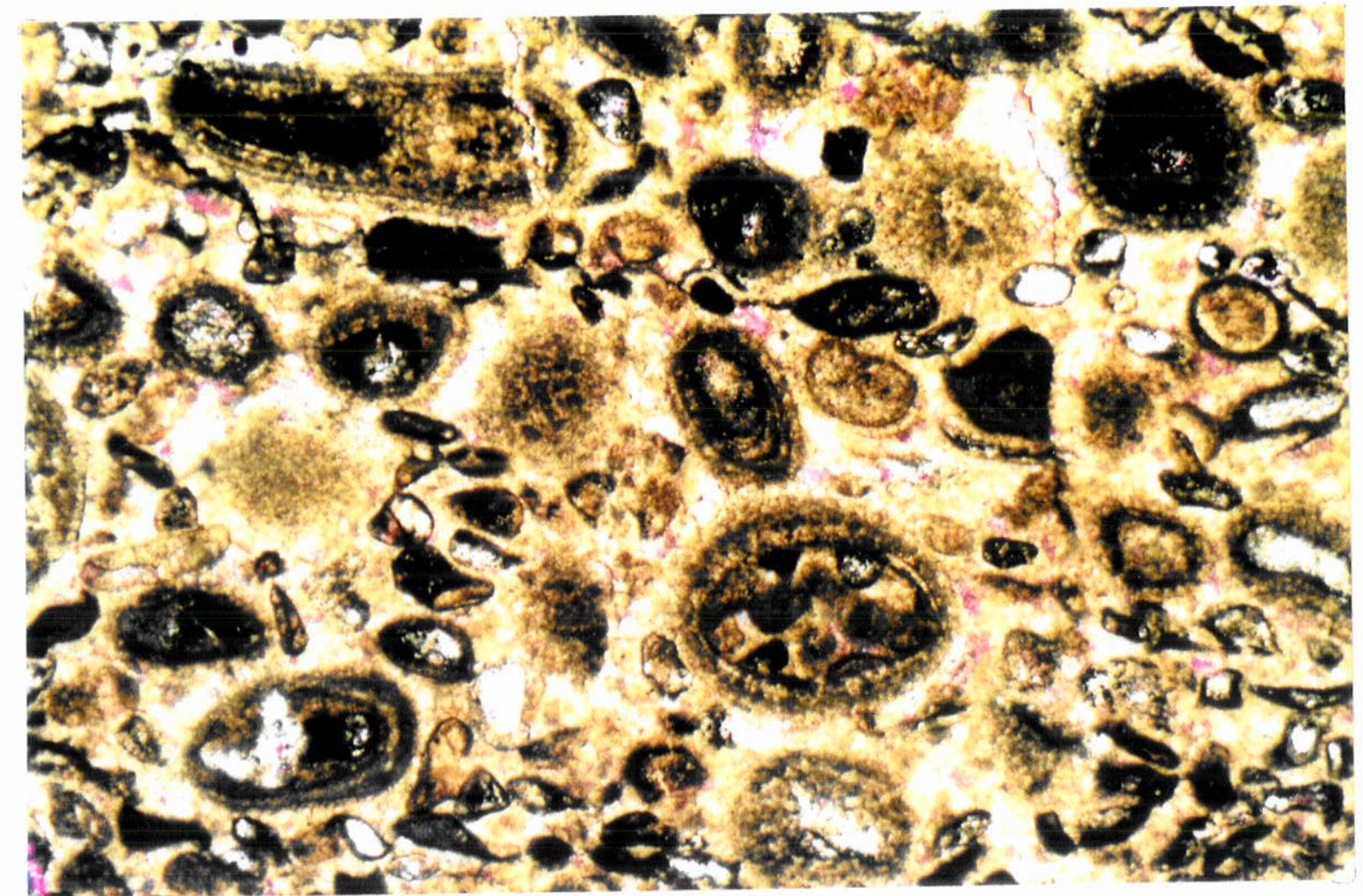

Foto 1 - Fotomicrografia de calcarenito oolítico parcialmente silicificado; observar presença de oólitos micríticos ou micritizados (Fácies Caoo). Intervalo 3. Mina da Bocaina. P.G./X.N. 30x

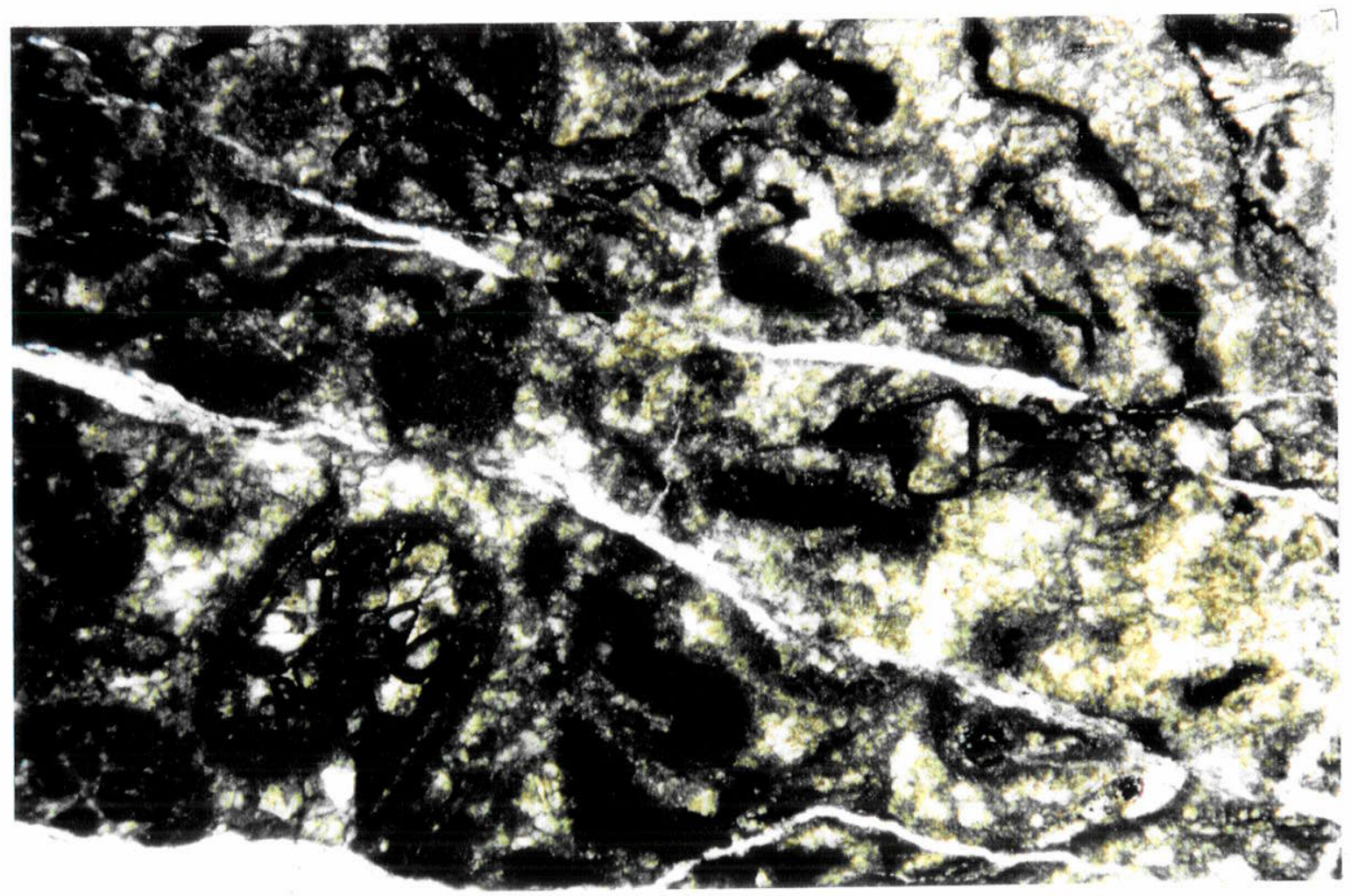

Foto 2 - Fotomicrografia de calcarenito oolítico onde se observa deformação da rocha, com desenvolvimento de textura semelhante à espastolítica e fraturamento de grãos. Fácies Caoo, Intervalo 3. Perfil 1, na Mina da Bocaina. L.N. 30x 


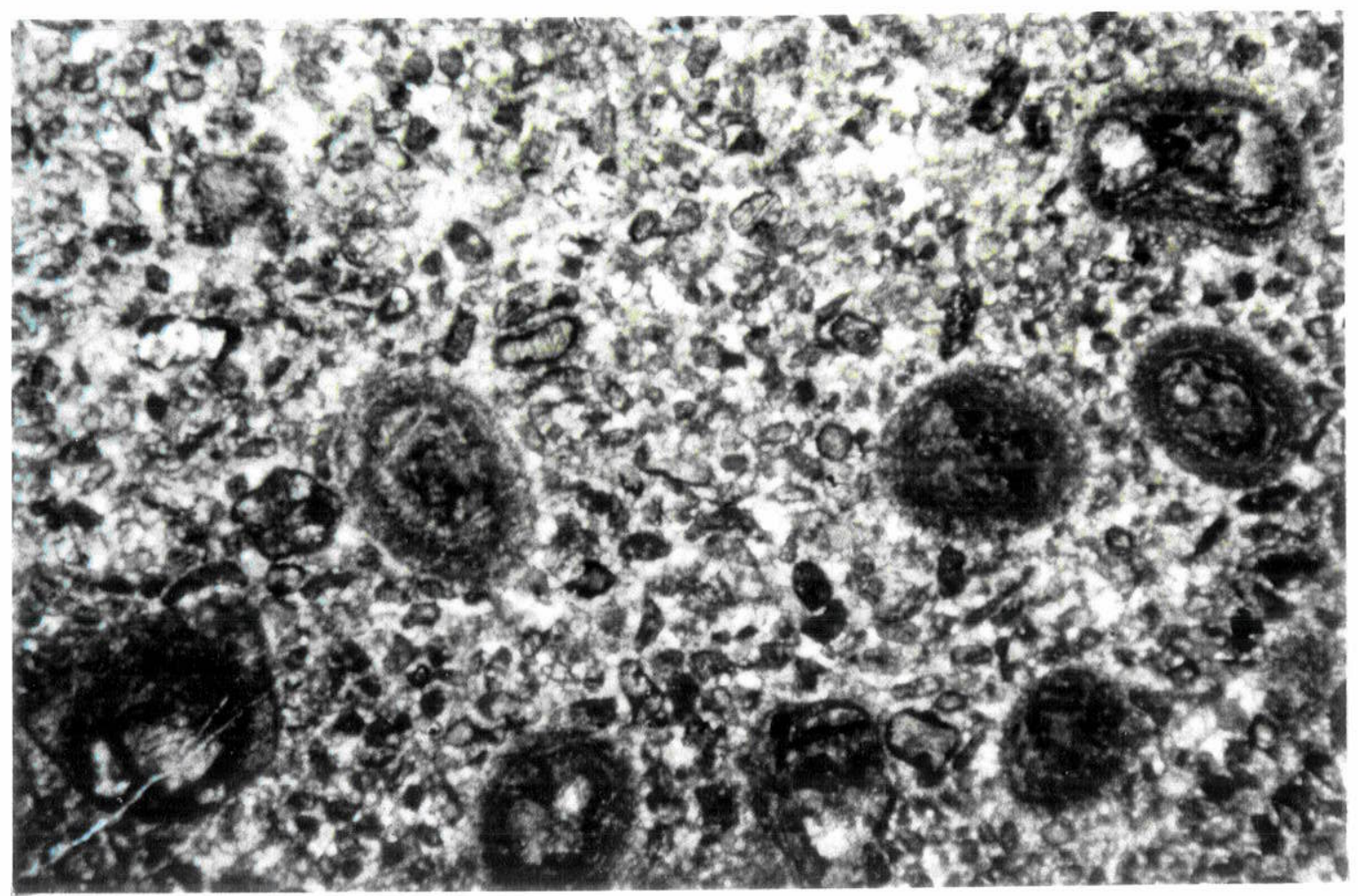

Foto 1 - Fotomicrografia de calcarenito parcialmente oolítico; constitui a matriz do calcirrudito com granodecrescência ascendente que ocorre associado à Fácies Caoo, no Intervalo 3. Mina da Bocaina. L.N. 25x

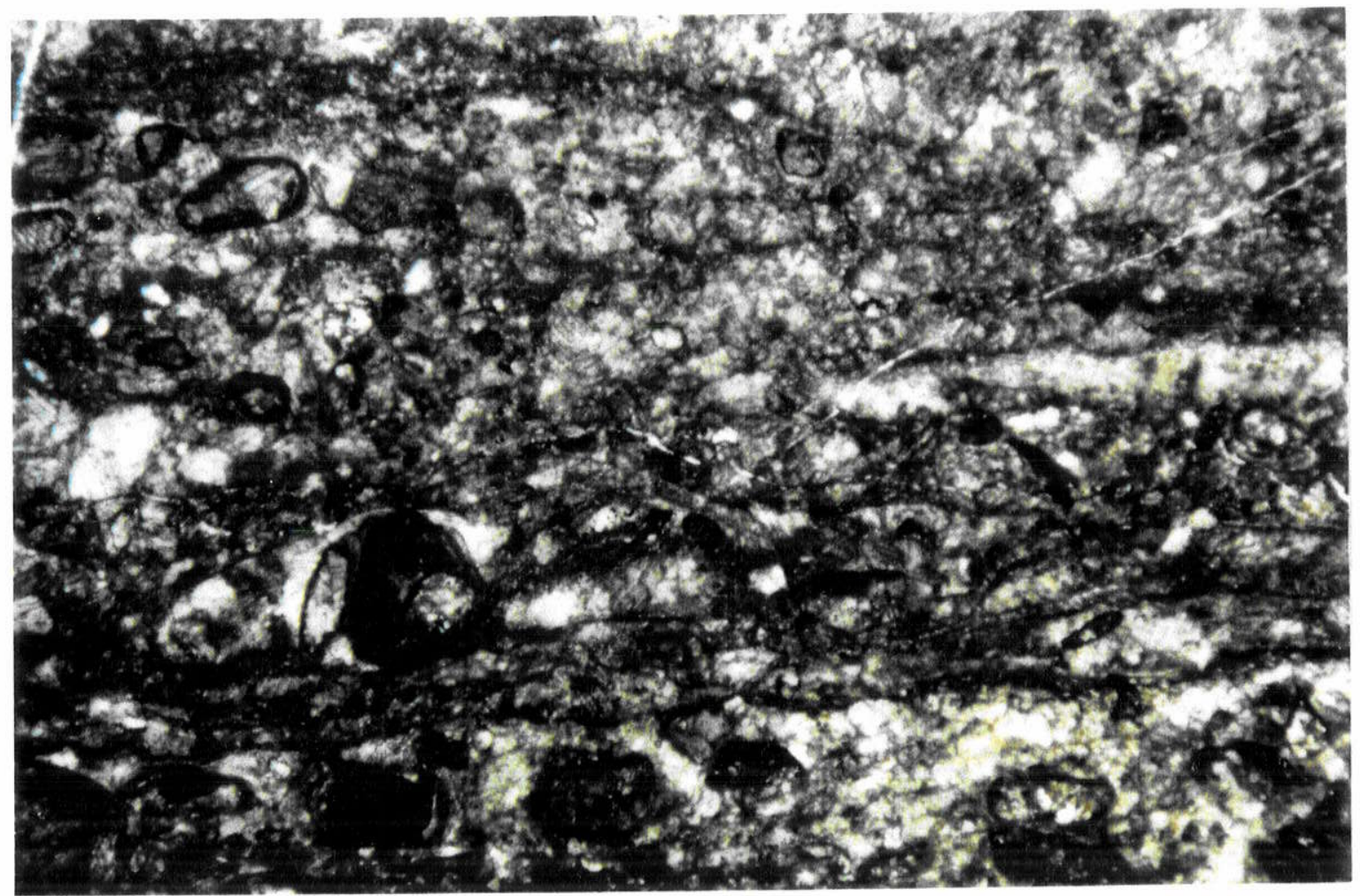

Foto 2 - Fotomicrografia de calcarenito parcialmente oolítico (Fácies Caoo), estabilizado por por filmes microbianos; constitui a base sobre a qual se assentam alguns dos biohermas superiores da Fácies CE. Intervalo 3, Perfil 1, Mina da Bocaina. L.N. 25x 

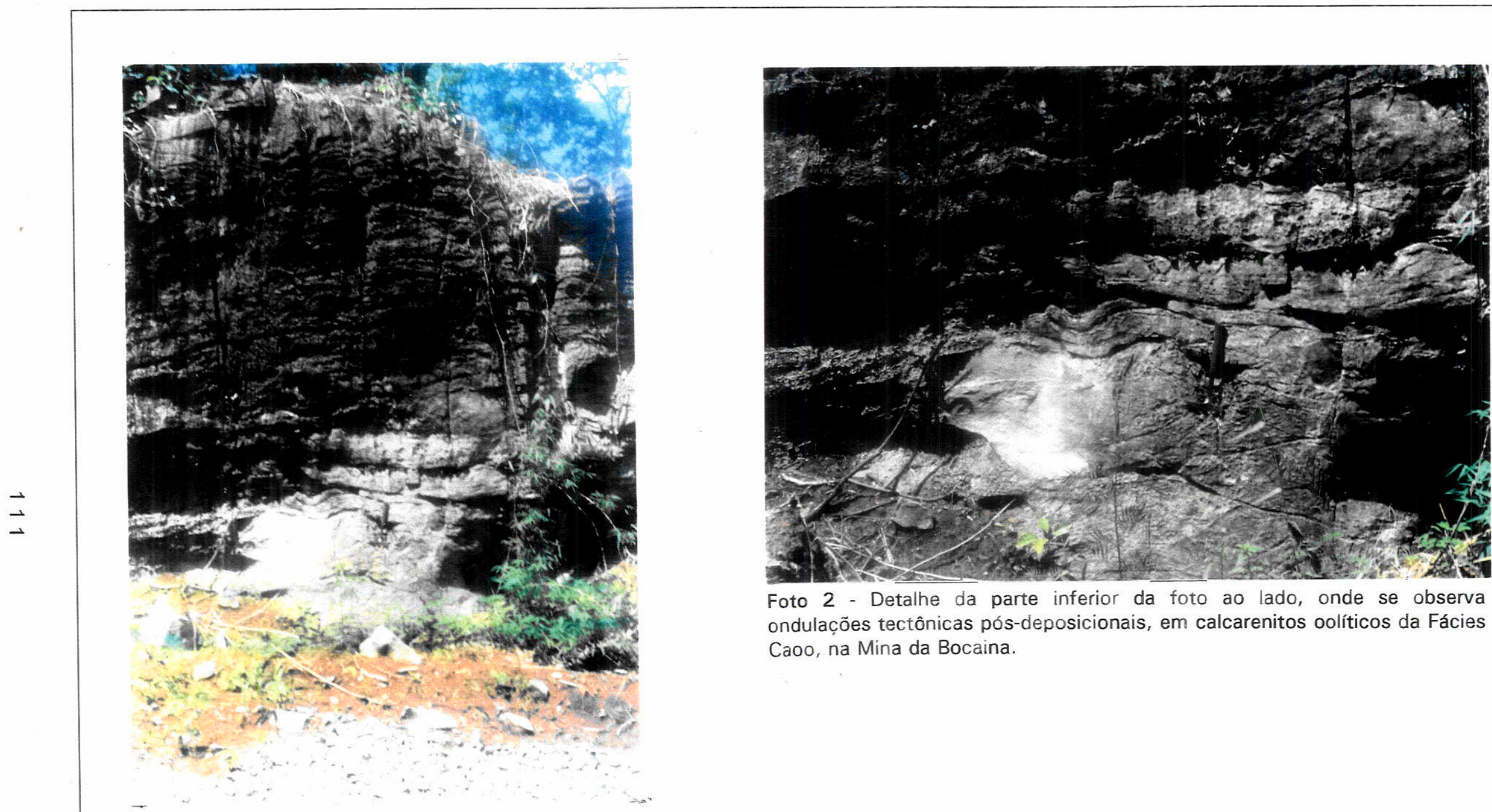

Foto 2 - Detalhe da parte inferior da foto ao lado, onde se observa ondulaç̃ões tectônicas pós-deposicionais, em calcarenitos oolíticos da Fácies Caoo, na Mina da Bocaina.

Foto 1 - Vista geral dos calcarenitos de topo do Perfil 1 na Mina da Bocaina. Intervalo 4. A altura do afloramento é de quatro metros. 
Em lâmina delgada observa-se um grainstone parcialmente oolítico, de arcabouço aberto, mal selecionado, com grãos areia muito grossa (oólitos) misturados a areia fina; secundariamente, ocorrem grãos de várias frações arenosas. Os oólitos são esféricos a ovalados e apresentam vestígios de capas oolíticas concêntricas; alguns grãos têm algumas capas substituídas por sílica e raros grãos são policompostos (Prancha 51, foto 1 e Prancha 52). Os grãos aloquímicos, areia fina a média podem, em parte, ser identificados como oólitos, mas a maioria deles, embora seja bem arredondada, não guarda resquícios de capas concêntricas, estando fortemente neomorfizada.

O calcarenito de topo da fácies é um grainstone oolítico, de granulaçäo grossa e arcabouço aberto (Prancha 51, foto 2), composto por gräos com vestígios de franja isópaca fortemente neomorfizada. Os oólitos possuem capas concêntricas bem desenvolvidas, mas aparentemente não apresentam núcleo diferenciado; raros gräos são policompostos e constituem grapestones, de granulaçäo areia muito grossa ou grânulos. Estão fortemente afetados pelo neomorfismo, e em alguns casos ocorre silicificação de algumas capas, ou de todo o oólito.

\subsection{9 - FÁCIES Can: Calcarenitos neomorfizados}

Os calcarenitos neomorfizados ocorrem na Mina da Bocaina, nos intervalos 3 e 4, associados a calcarenitos oolíticos. No geral exibem intercalaçöes delgadas de calcilutitos.

No Intervalo 3, observa-se niveis centimétricos de calcarenitos, com intercalaçöes delgadas de calcilutitos, que exibem laminaçōes cruzadas por ondas e pequenas marcas onduladas.

Em lâmina delgada observa-se que o calcarenito é fortemente neomorfizado, com obliteração parcial da textura original da rocha. Observa-se vestígios de gräos bem arredondados, ovalados, irregulares ou esféricos, mal selecionados, de granulação areia fina a grossa.

Os niveis de calcilutito também estão fortemente afetados pelo neomorfismo, e podem apresentar calcita palissádica preenchendo pequenos espaços, no contato entre o calcilutito e o calcarenito (Prancha 53, foto 1). Silicificaçäo incipiente e grãos esparsos de pirita, ocorrem tanto nos niveis granulares, quanto nos lamosos.

No Intervalo 4, os calcarenitos neomorfizados compöem um pacote carbonático de cerca de dois metros de espessura, com estratos centimétricos, onde se observa grandes ondulaçōes, irregulares. Apresentam variação lateral de espessura e de cores. Em lâminas delgadas observa-se calcário finamente granular em contato com calcilutito finamente 


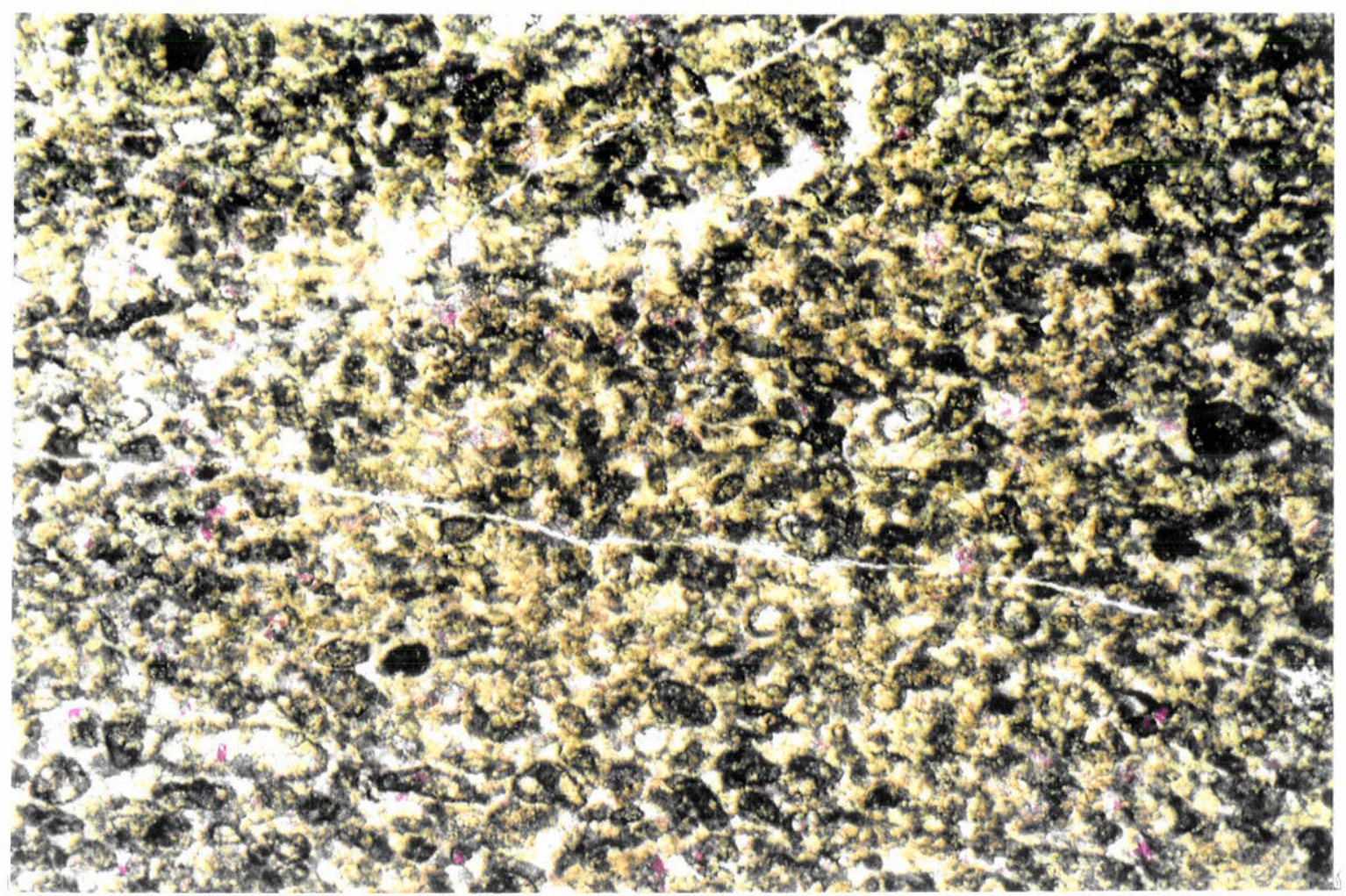

Foto 1 - Fotomicrografia de calcarenito parcialmente oolítico intensamente neomorfizado e parcialmente silicificado. Fácies Caoo. Intervalo 4. Mina da Bocaina. P.G./X.N. 30x

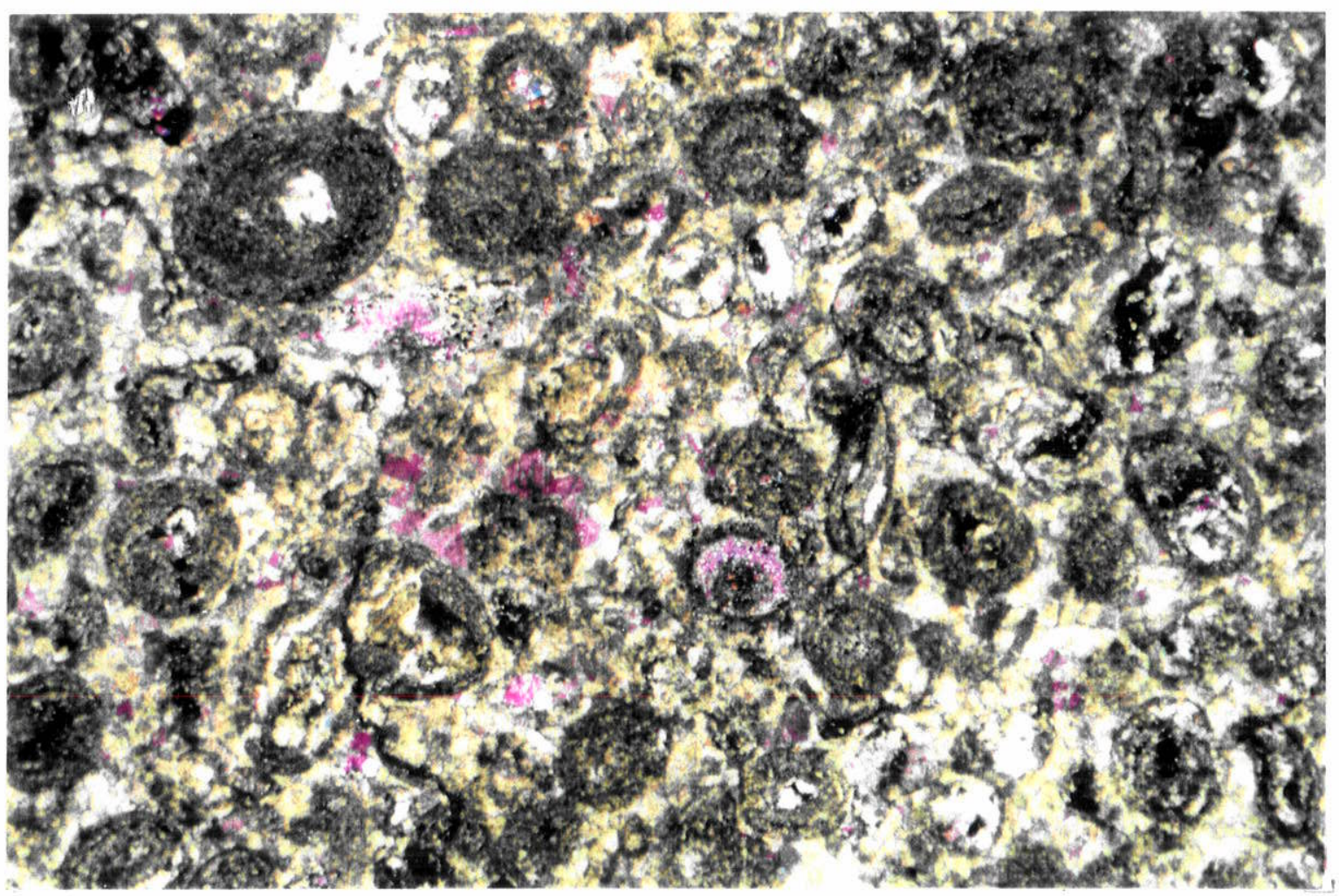

Foto 2 - Fotomicrografia do calcário oolítico do topo da seção aflorante na Mina da Bocaina. Observar que os oólitos estão neomorfizados, são bem formados, com capas concêntricas bem desenvolvidas; apresentam dissolução de algumas capas ou do núcleo, que foram substuídos por microquartzo. Fácies Caoo, Intervalo 4. P.G./X.N. 30x 


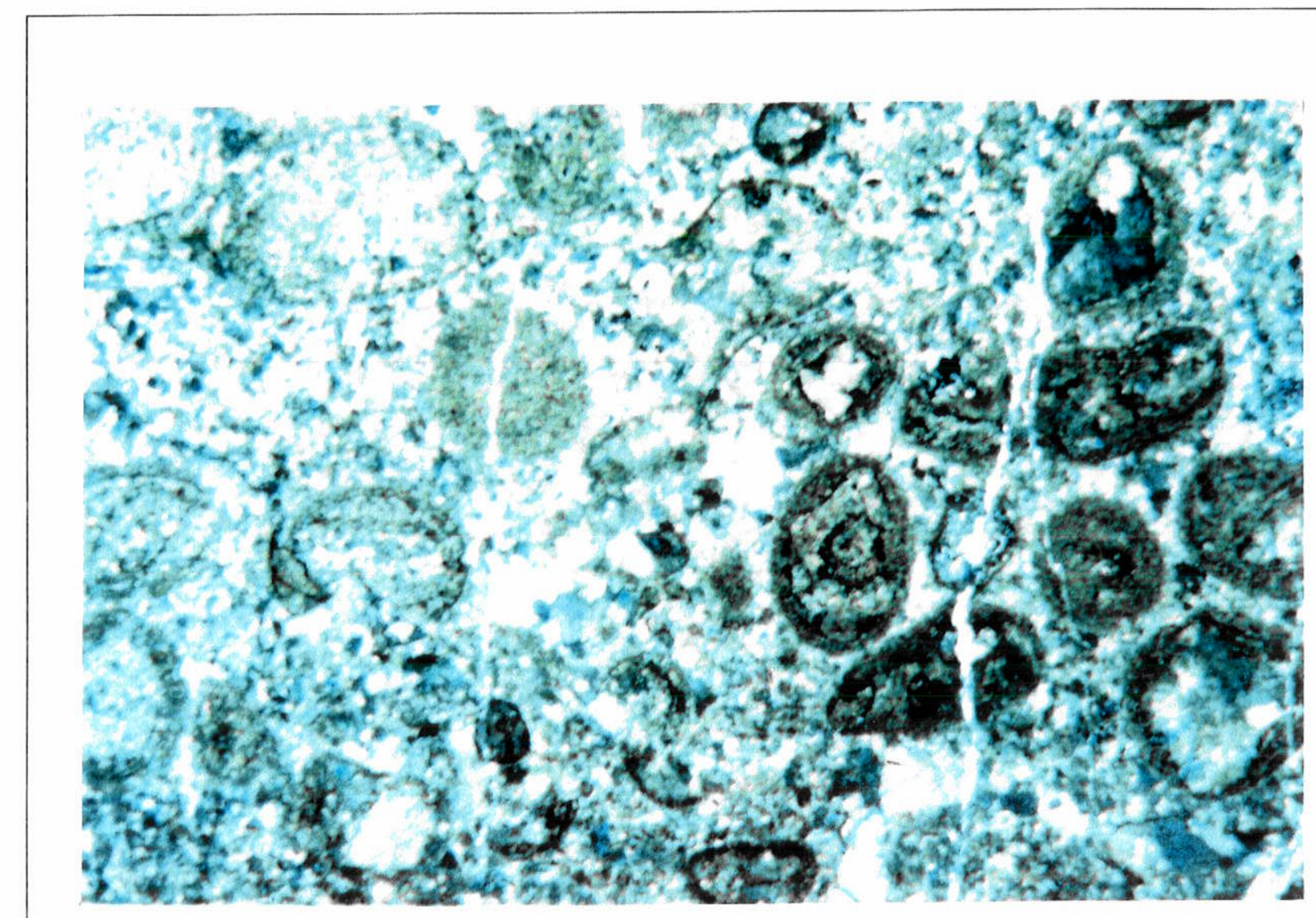

Foto 1 - Fotomicrografia de calcarenito parcialmente oolítico, fortemente neomorfizado; às vezes observa-se apenas vestígios das capas concêntricas. Fácies Caoo. Intervalo 4. Mina da Bocaina. X.N. 30x

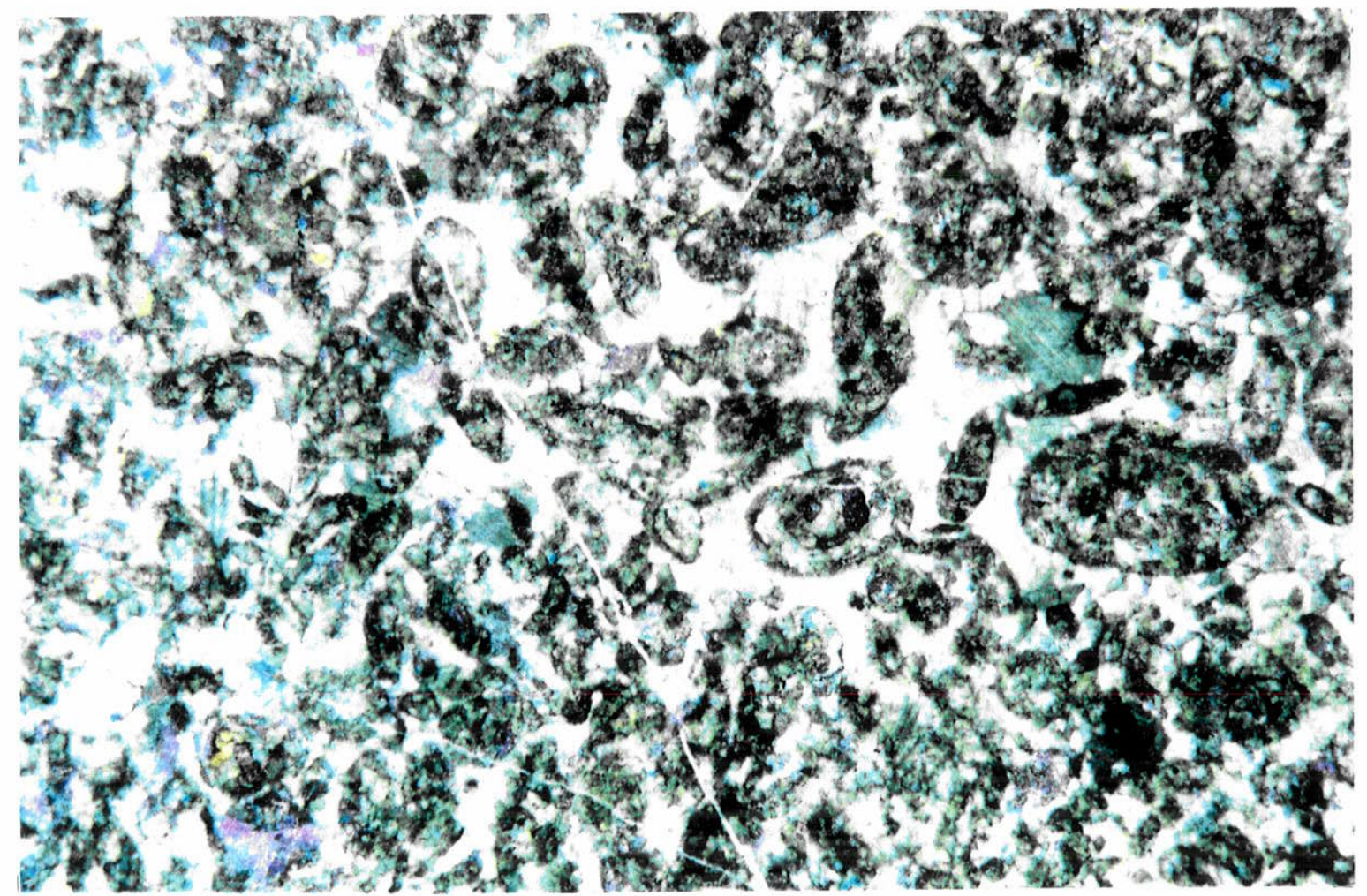

Foto 2 - Fotomicrografia de calcarenito oolítico da Fácies Caoo, muito neomorfizado. Intervalo 4, na Mina da Bocaina. Perfil 1. X.N. 30x 


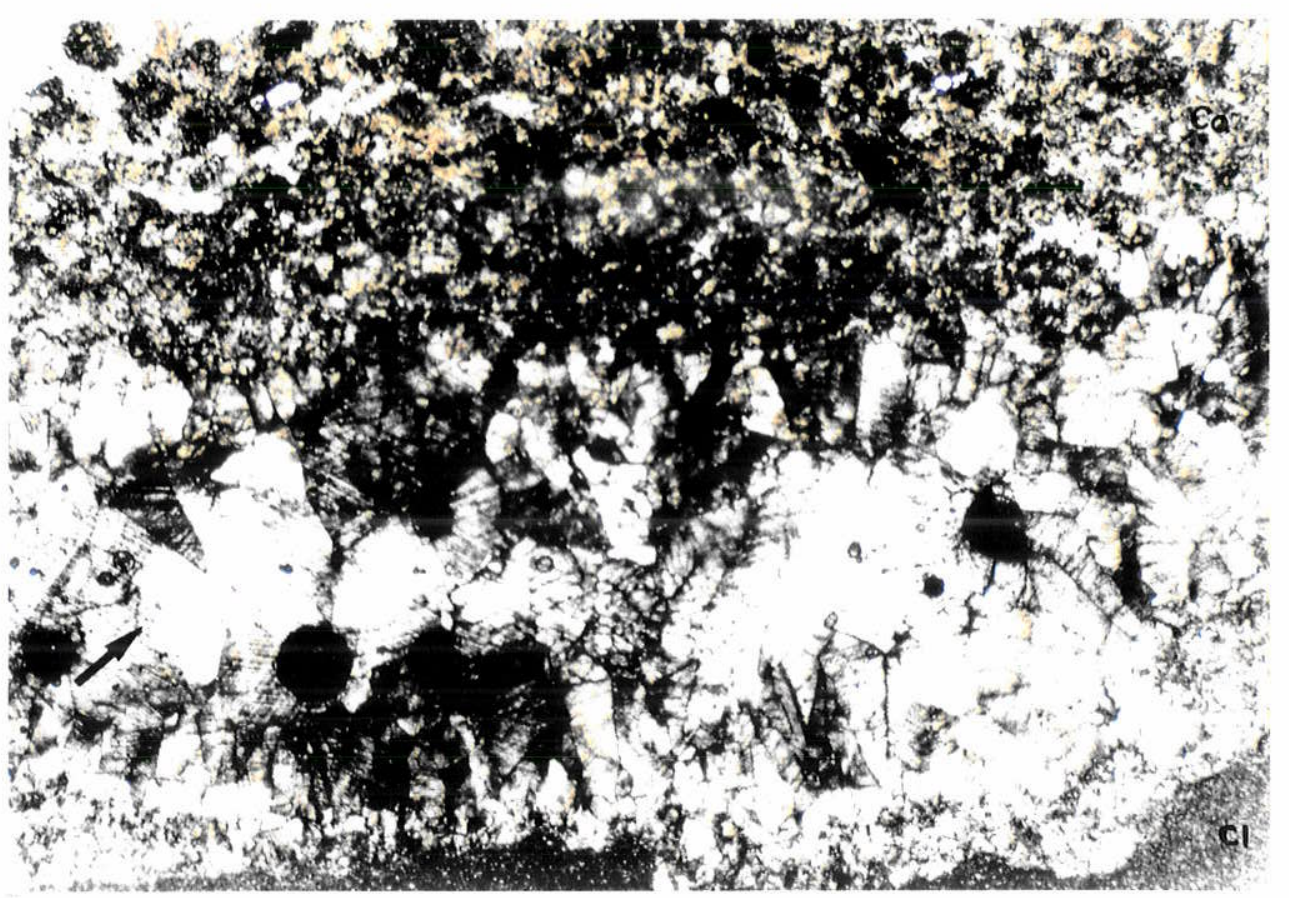

Foto 1 - Fotomicrografia de calcarenito neomorfizado (Fácies Can), em contato com calcilutito, através de calcita palissádica (seta). Intervalo 3, Mina da Bocaina. L. N. 10x

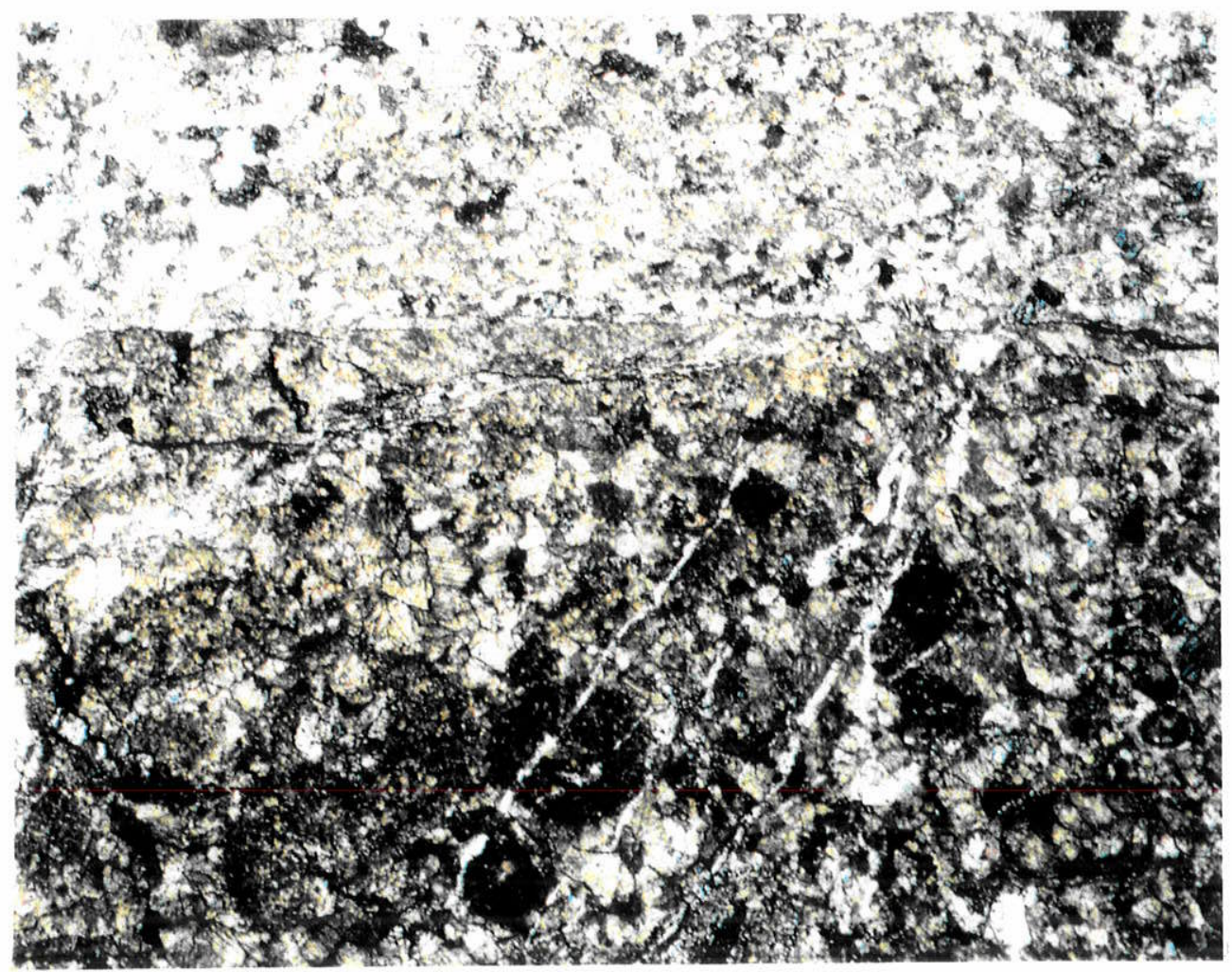

Foto 2 - Fotomicrografia de calcarenito parcialmente oolítico, em contato com nível lamoso, fortemente neomorfizados. Fácies $\mathrm{CaCl}$, Intervalo 3, na Mina da Bocaina. X.N. 30x 
laminado (Prancha 54, foto 1) ou um mosaico de pseudoespato contendo vestígios de aloquimicos (Prancha 54 , foto 2 ).

\subsection{0 - FÁCIES CaCl: Calcarenito com intercalações de calcilutitos}

Esta fácies tem cerca de dois metros metros de espessura e foi observada na Mina da Bocaina. Constitui um pacote de calcarenito freqüentemente oolítico, que para o topo da fácies, apresenta intercalaçōes cada vez mais importantes de calcilutitos. Como estruturas sedimentares, observa-se laminações cruzadas por ondas, que gradativamente, passam a apresentar intercalações de sedimentos de granulação fina, compondo acamamento flaser e wavy. Podem apresentar nódulos de sílex associados (Prancha 53, foto 2).

Em lâmina delgada, observa-se que os calcarenitos são compostos por aloquímicos fortemente neomorfizados, oolíticos ou não; os sedimentos finos são constituídos por calcilutitos e calcissiltitos grossos, que apresentam laminação plano-paralela, silicificação incipiente, e contêm cristais esparsos de pirita.

\subsection{1 - FÁCIES CII: Calcilutito laminado}

Constitui um pacote de cerca de um metro de espessura, é de cor cinza escuro a preto, e apresenta intercalaçōes milimétricas de calcissiltitos e/ou calcarenitos de granulação muito fina. O calcilutito é micrítico, finamente laminado, com laminações submilimétricas, plano-paralelas.

Os calcissiltitos ou calcarenitos são de cor cinza claro, apresentam granodecrescência ascendente e laminações cruzadas por ondas. Em lâmina delgada observa-se vestígios de aloquímicos micríticos ou micritizados, de granulação areia muito fina a silte muito grosso e grande quantidade de pirita disseminada (Prancha 55 , foto 1 ).

\subsection{2 - FÁCIES Csl: Calcissiltitos laminados}

Os calcissiltitos laminados constituem niveis amalgamados e apresentam filmes de matéria carbonosa associada a argilominerais, nos planos de acamamento.

Subordinadamente, são observadas intercalações de calcarenitos e lentes de matéria carbonosa. Próximo ao topo da fácies, observa-se intercalações cada vez mais freqüentes de niveis lamosos de cor clara, contendo argilominerais, que constituem 


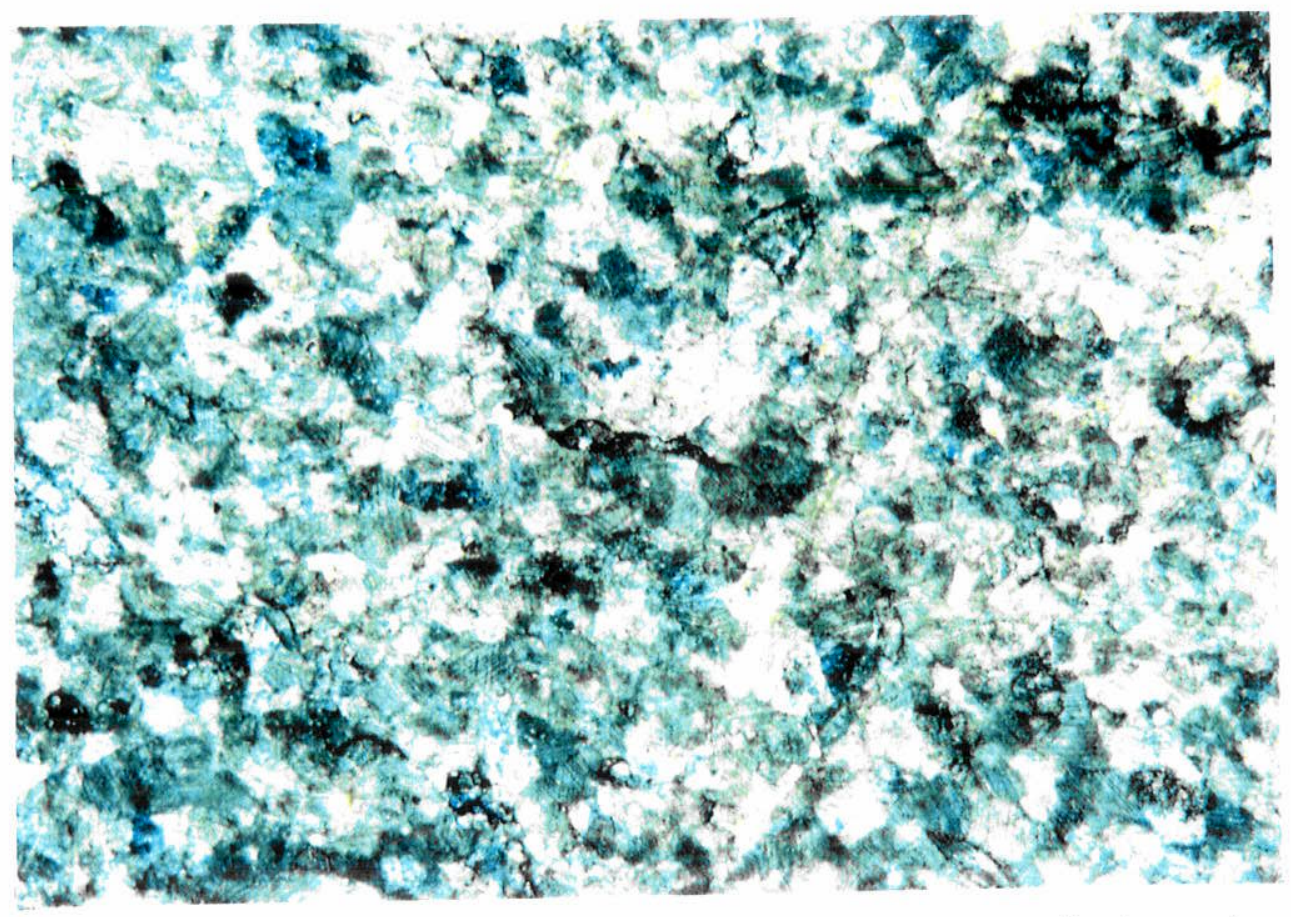

Foto 1 - Fotomicrografia de calcarenito intensamente neomorfizado, onde observa-se apenas vestígios de aloquímicos. Fácies Can, no Intervalo 4. Perfil 1, Mina da Bocaina. X.N. 70x

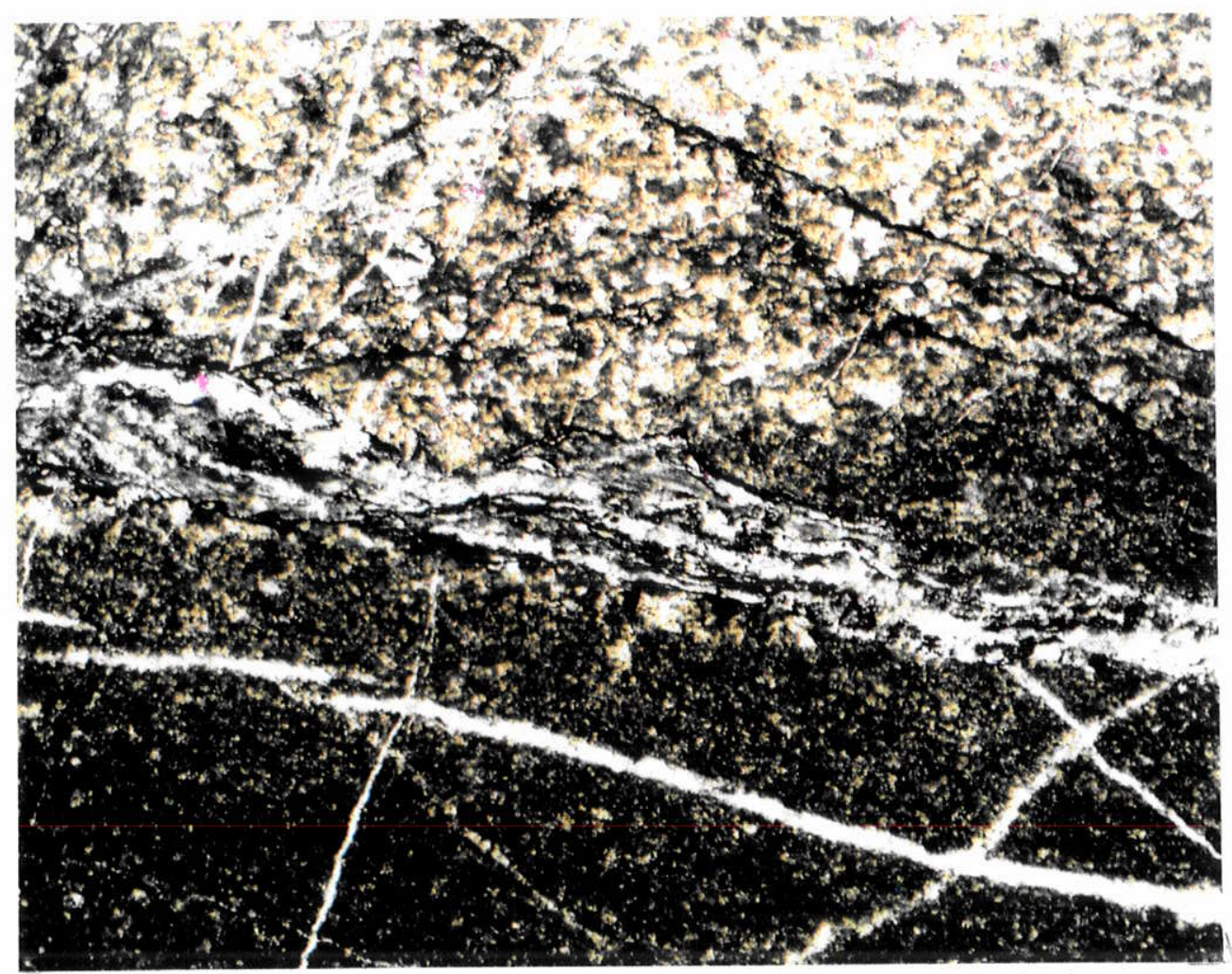

Foto 2 - Fotomicrografia de calcarenito neomorfizado e tectonizado, em contato com nível de calcilutito. Fácies Can, Intervalo 4. Mina da Bocaina. P.G./X.N. $20 x$ 


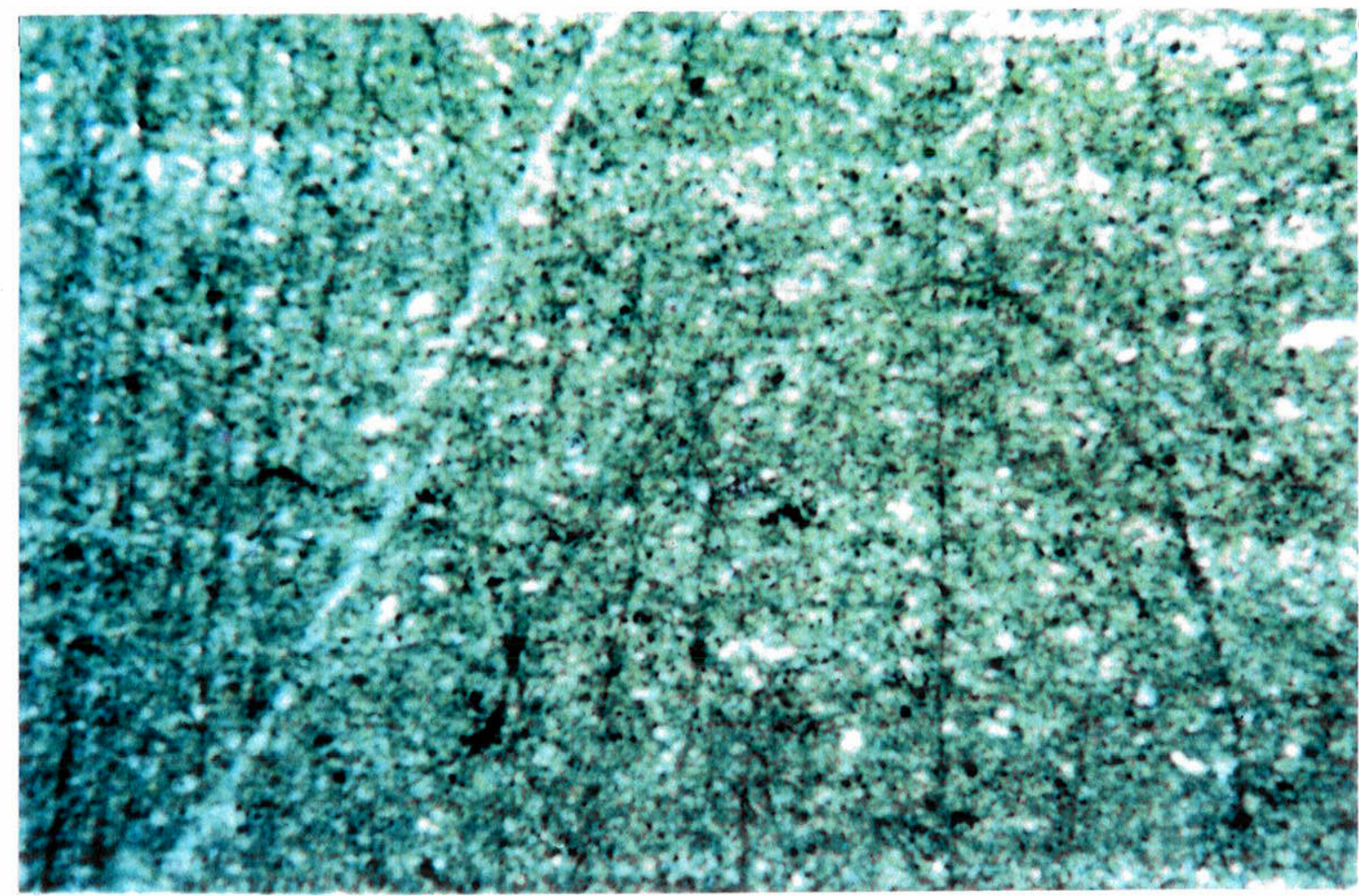

Foto 1 - Fotomicrografia de calcilultito laminado, parcialmente neomorfizado; observar a presença de pirita. Fácies CII. Mina da Bocaina. X.N. 20x

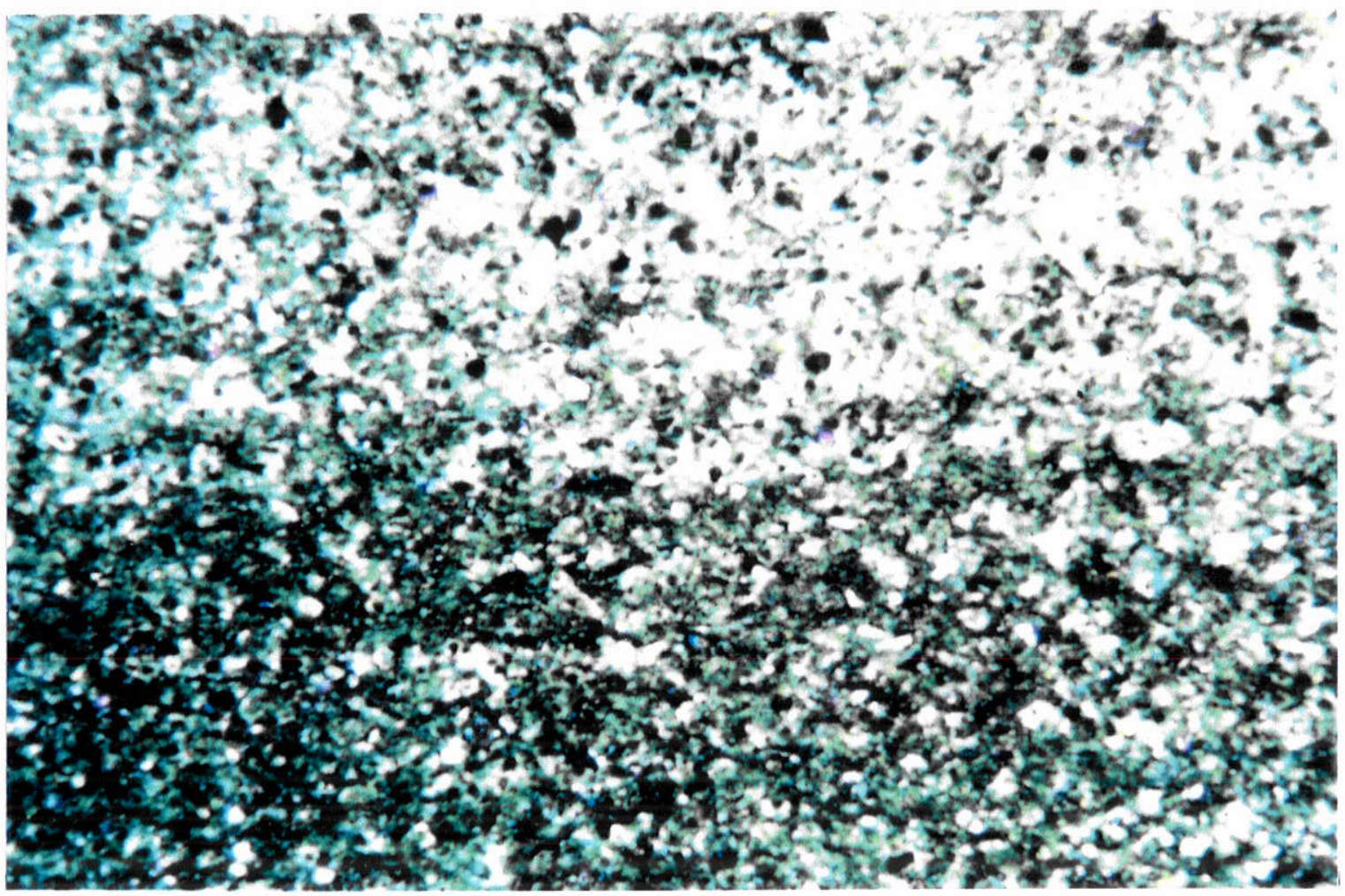

Foto 2 - Fotomicrografia de calcissiltito laminado, peloidal e intensamente neomorfizado. Presença de pirita. Fácies Cls. Mina da Bocaina. X.N. 30x 
acamamento flaser. Nessa faixa, o carbonato apresenta aspecto listrado, com alternâncias de bandas claras e escuras. Pequenas gretas de contração, preenchidas por calcita espática, são observadas nos níveis lamosos. Também intercaladas no topo da fácies, ocorrem calcarenitos grossos que apresentam gradação normal. Todo o pacote apresenta cerca de quatro metros de espessura (Prancha 57).

Os calcissiltitos são peloidais (Prancha 55, foto 2 e Prancha 56, foto 1), finamente laminados, e podem apresentar delgadas laminações cruzadas por ondas de baixo ângulo, truncadas por suaves marcas onduladas. Os calcissiltitos de topo exibem alguns cristais de anidrita e raros grãos arredondados de quartzo detrítico.

Os calcarenitos, de granulação muito fina a média, são constituídos por pelóides muito escuros, que eventualmente podem estar neomorfizados; apresentam granodecrescência ascendente, geralmente com lama carbonática no topo, laminações cruzadas por ondas e marcas onduladas decimétricas. Observa-se também calcarenito oolítico, grainstone, de granulação média, bem selecionado, de arcabouço aberto. É composto por oólitos ovalados a esféricos, neomorfizados, que apresentam vestígios de capas concêntricas, com silicificação incipiente no centro dos grãos; raramente se observam oólitos micríticos (Prancha 56, foto 2). Acima do calcarenito oolítico, o calcissiltito é de cor mais clara e contém delgadas intercalações lamosas (Prancha 58 , foto 1).

As lentes carbonosas são finamente laminadas e têm espessura média de 20 centímetros e cerca de três metros de comprimento observado. Análise de um desses niveis por difração de Raio $x$, identificou os seguintes minerais: quartzo, calcita, clorita, mineral do grupo das micas, pirita, esmectita e traços de feldspato, bem como a presença de matéria orgânica. O nivel é afossilífero, segundo análise palinológica efetuada.

\subsection{3 - FÁCIES MRG: Margas}

Margas foram observadas apenas no Perfil 6, na BR-354, nas proximidades de Arcos (Prancha 58, foto 2). São suborizontais, de cor cinza claro com intercalações esverdeadas e rosadas. $O$ plano de estratificação é planar ou ligeiramente ondulado.

Laminação plano-paralela a ondulada, drapes, acamamento lenticular, laminações cruzadas por ondas de baixo ângulo, milimétricas e pequenas marcas onduladas são as principais estruturas sedimentares observadas. Sobre alguns niveis mais argilosos, observa-se pequenas massas esféricas de calcita, que talvez possam podem representar pseudomorfos de evaporitos. 


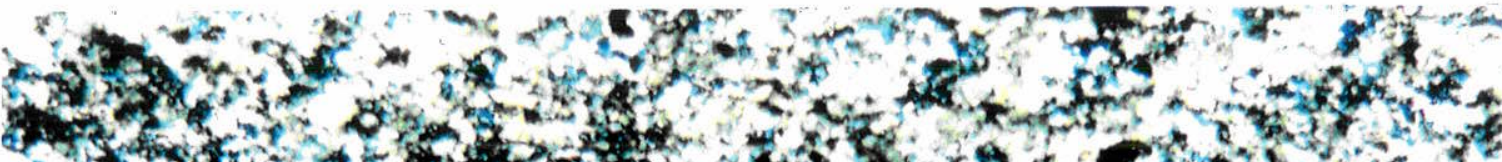

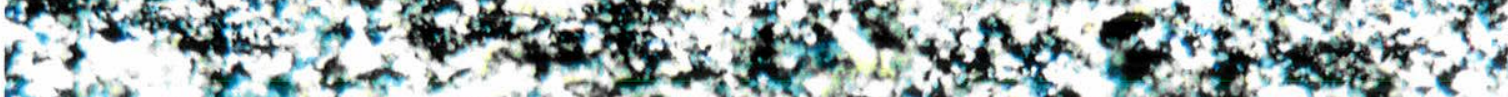

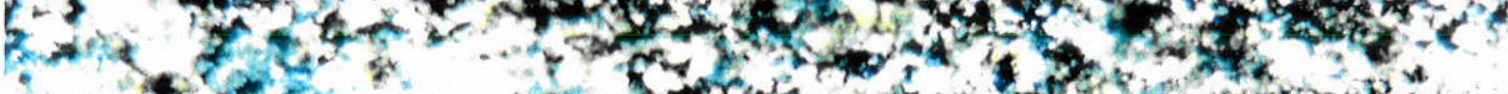

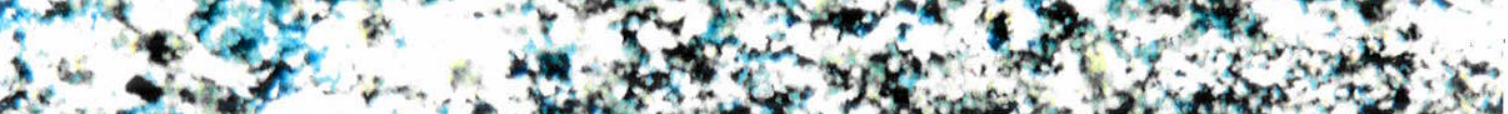

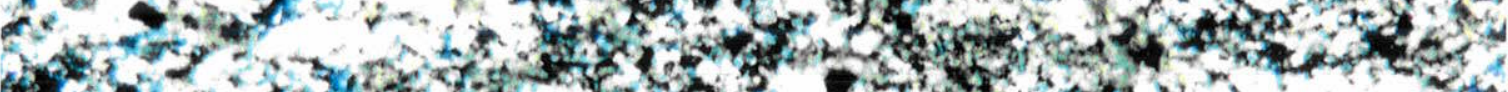

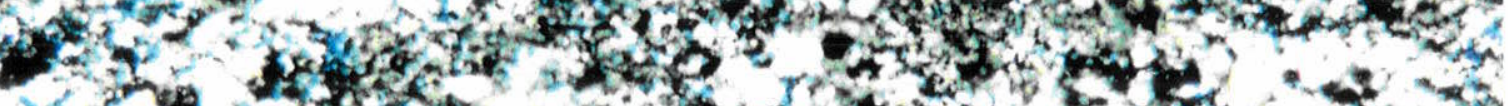

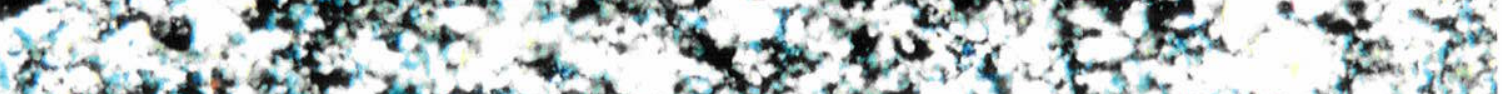

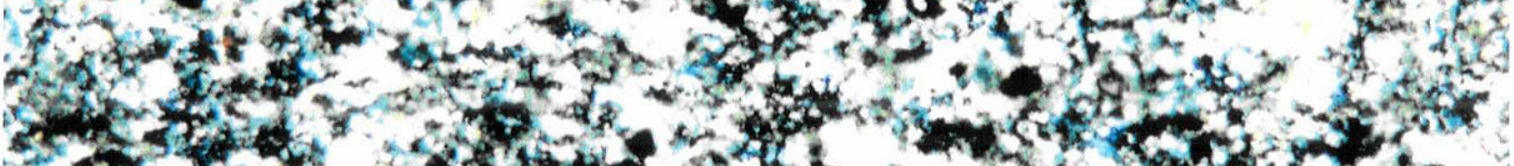

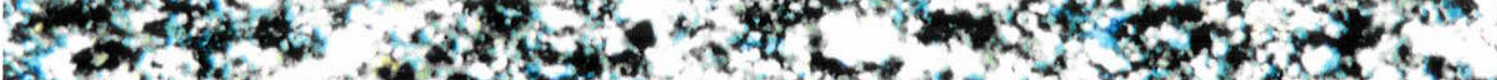

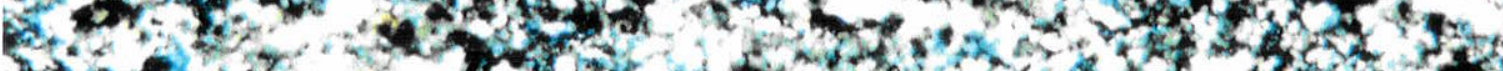

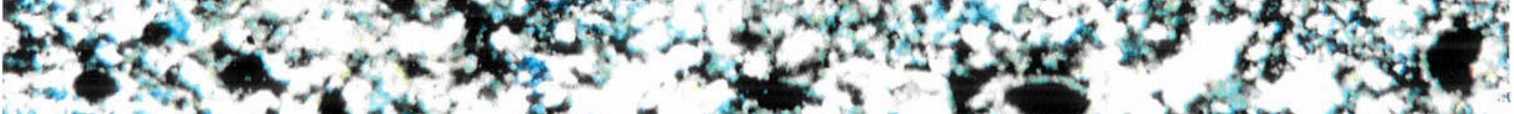

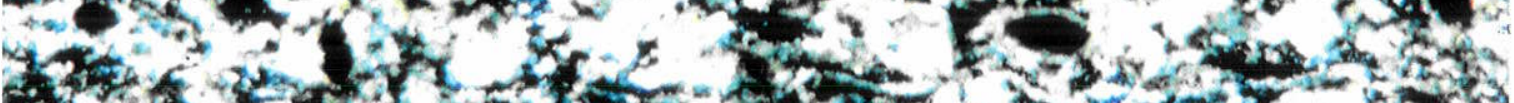

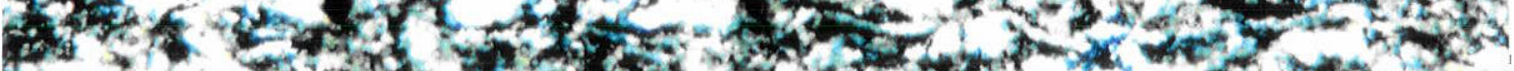

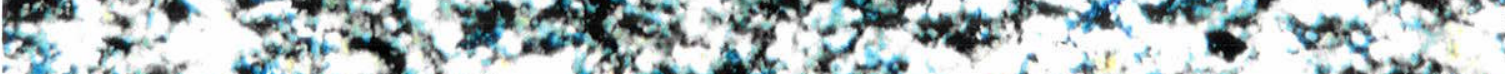

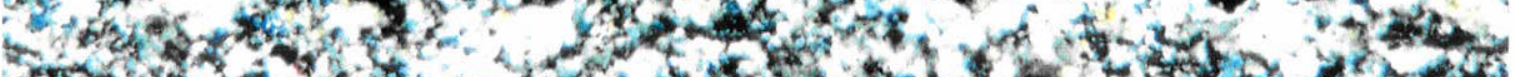

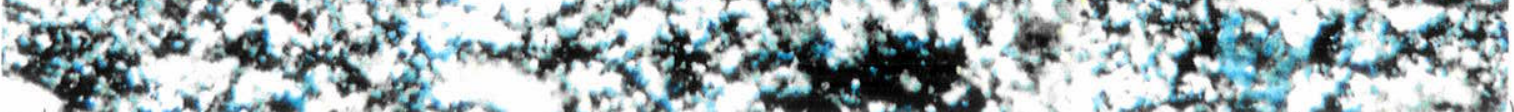
Foto 1 - Fotomicrografia de calcissiltito peloidal, laminado e parcialmente neomorfizado; Fácies Csl. Perfil 1, na Mina da Bocaina. X.N. 50x

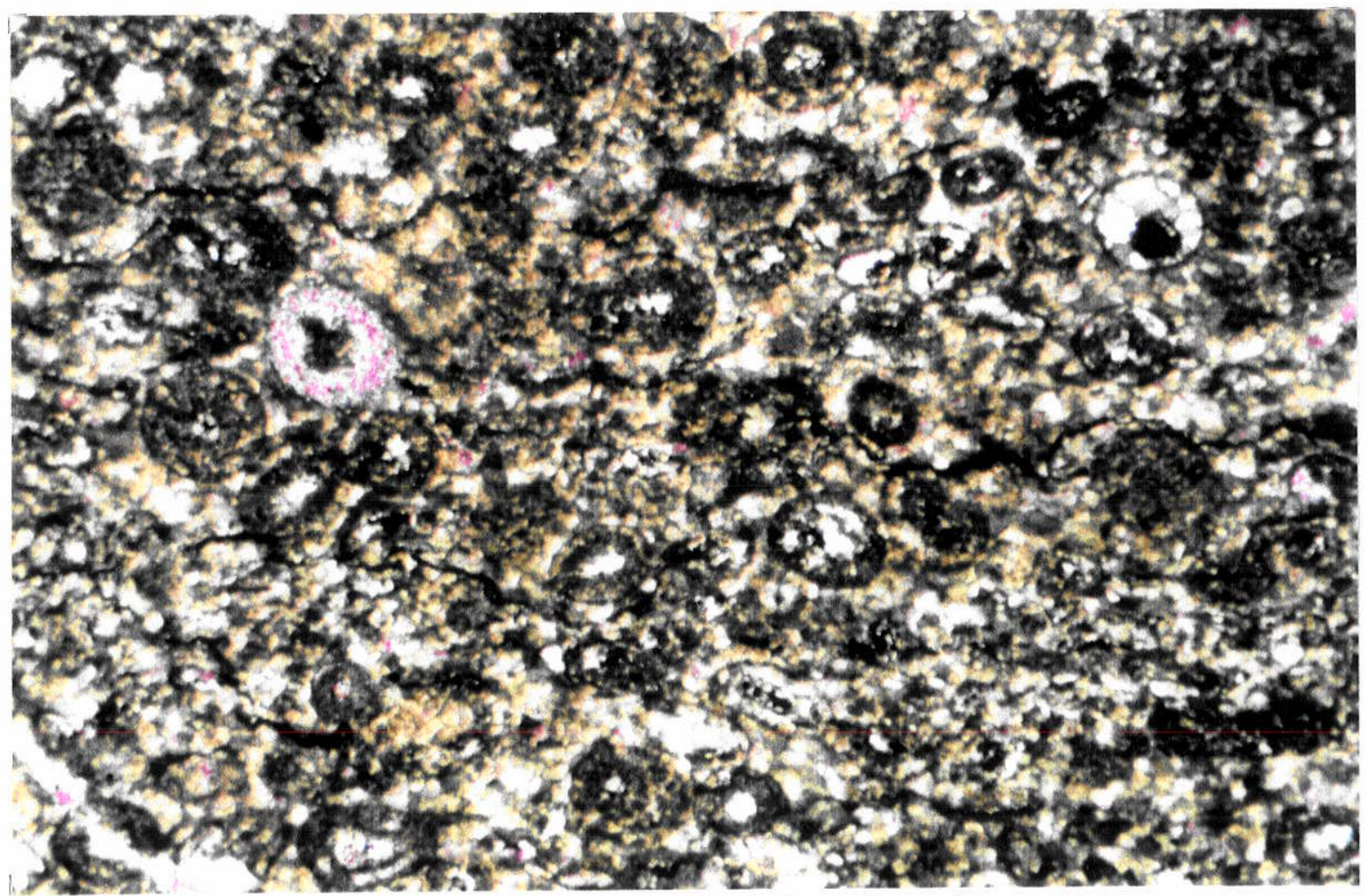

Foto 2 - Fotomicrografia de delgado nível de calcarenito oolítico em

calcissiltito laminado. P.G./X.N. 20x 

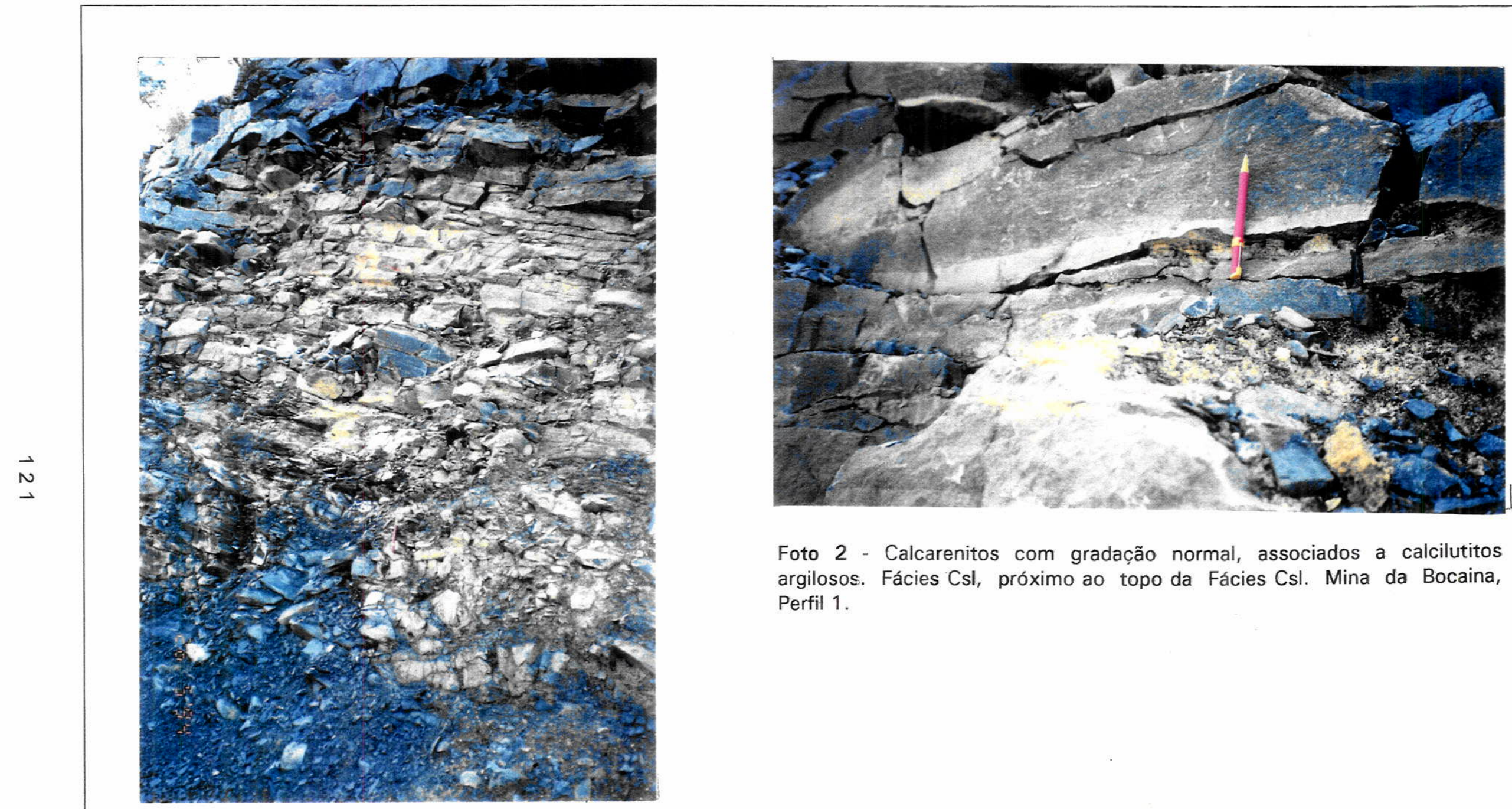

Foto 2 - Calcarenitos com gradação normal, associados a calcilutitos argilosos. Fácies Csl, próximo ao topo da Fácies Csl. Mina da Bocaina, Perfil 1.

foto 1 - Vista da parte basal da exposicão das Fácies Cll e Csl, na Mina da Bocaina. Espessura de três metros. 


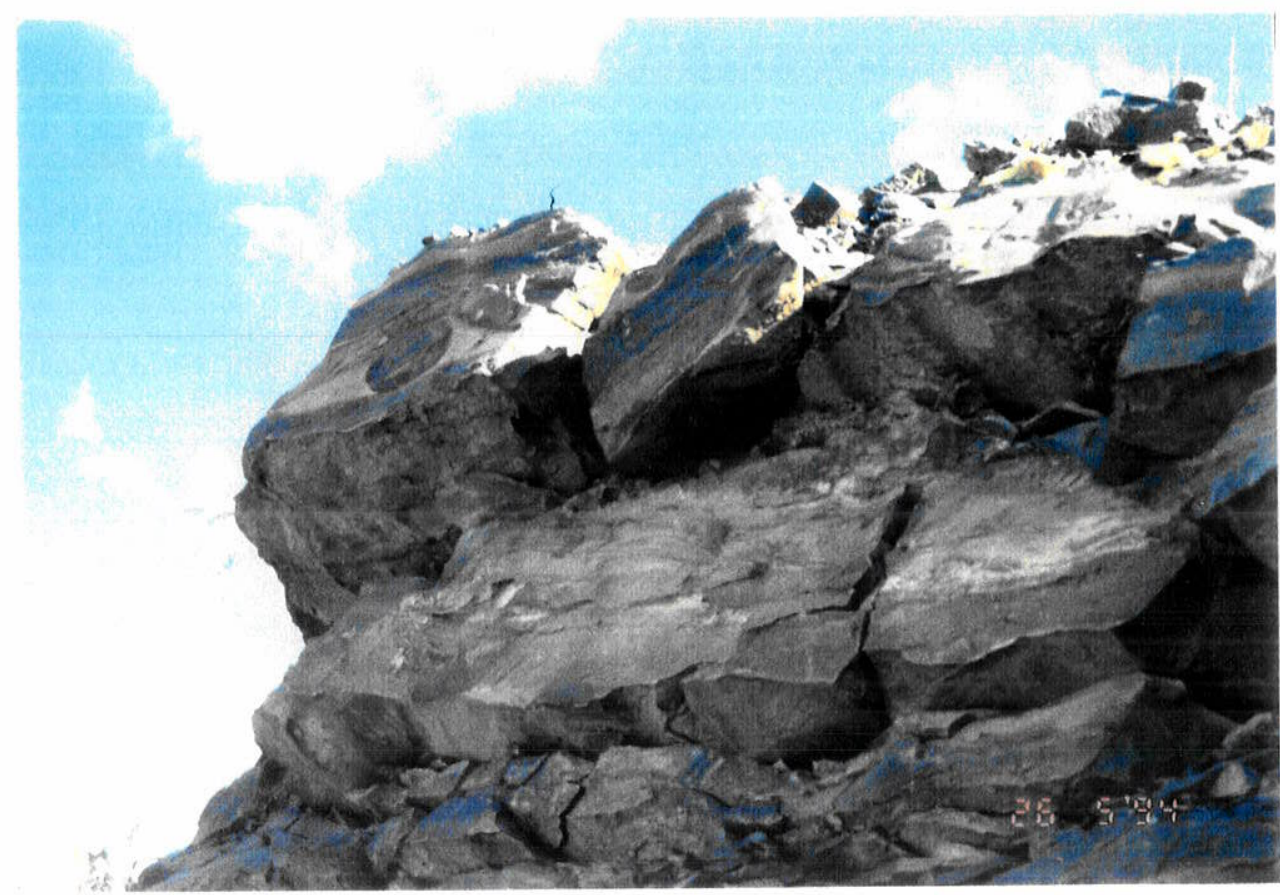

Foto 1 - Vista do topo da Fácies Csl, na Mina da Bocaina, onde apresenta intercalaões de calcilutitos argilosos de cor clara. A espessura do afloramento é de cerca de 3 metros.

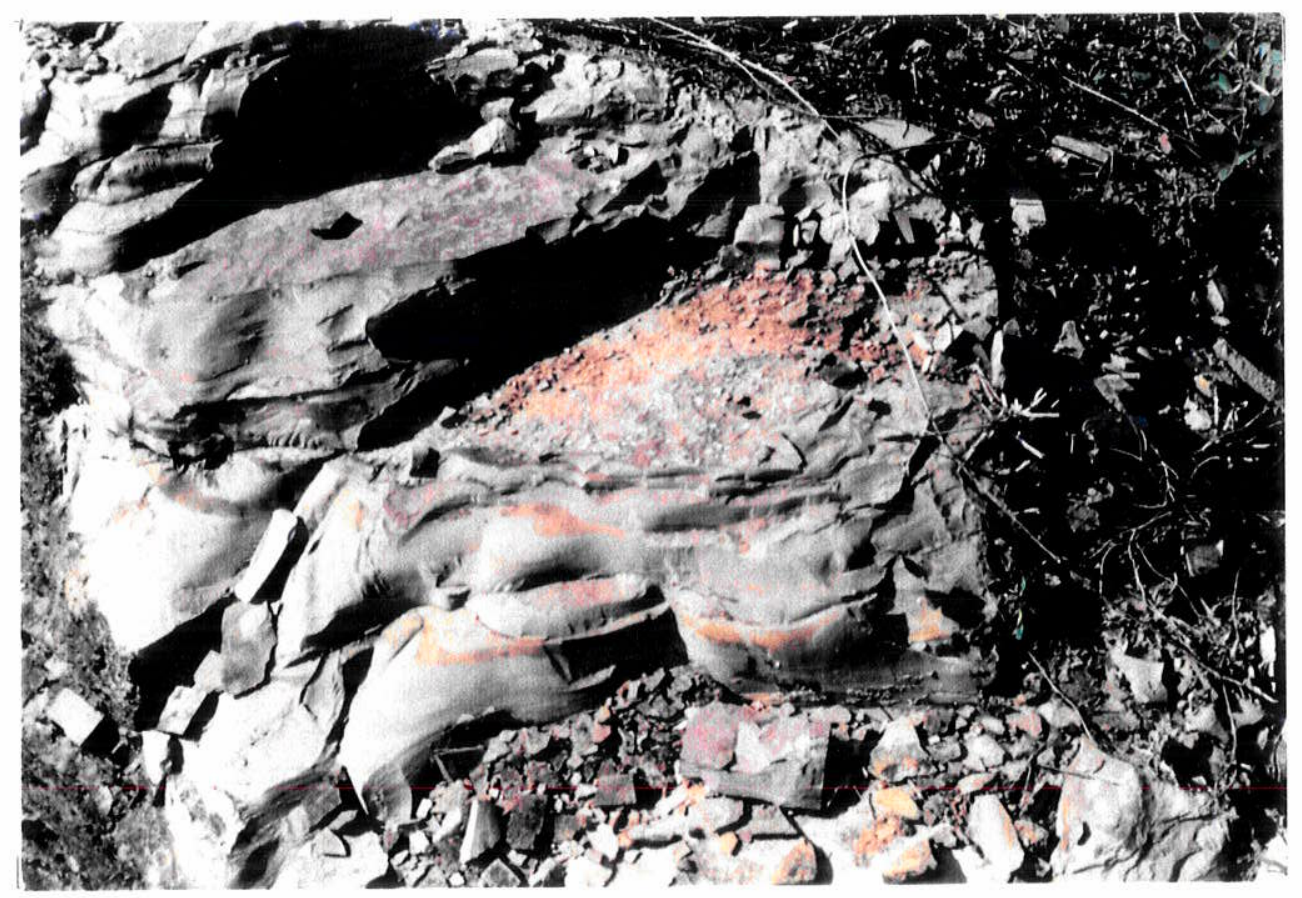

Foto 2 - Pequeno afloramento de marga, no Perfil 6, na estrada BR-354, nas proximidades de Arcos. 


\section{6 - DIAGÊNESE}

\section{1 - COMPACTAÇÃO}

Os processos de compactação são freqüentes em rochas carbonáticas e podem ser subdivididos em 2 categorias, mecânicos ou físicos, e químicos (Bathurst 1976). A compactação mecânica começa a atuar logo após a deposição do sedimento, enquanto a compactação química ocorre sob condições de soterramento profundo (deep buria).

A compactação mecânica produz, entre outros efeitos, empacotamento, fraturamento e rotação de grãos, além de impor uma redução considerável de espessura em sedimentos lamosos, por perda de água, com redução de porosidade.

A compactação química e a dissolução por pressão ocorrem sob soterramento de várias centenas de metros e as feições mais comuns são dissolution seams (Bathurst 1987), estilólitos e os contatos interpenetrativos de grãos, entre outros. Feições de compactação química, em especial dissolution seams, são proeminentes nos sedimentos lamosos do Intervalo 1, em especial nos níveis mais argilosos do calcário microbiano, onde desenvolve, ao menos parcialmente, bandeamento diagenético. Estilólitos ocorrem praticamente em todas as litologias, mas quando ocorrem em sedimentos lamosos, apresentam uma película de material argilo-carbonoso associado (Prancha 3, foto 6 e Prancha 59, foto 1 ).

\section{2 - CIMENTAÇÃO}

É um dos principais processos diagenéticos que afetam as rochas carbonáticas e ocorre a partir da precipitação química em cavidades preexistentes nos sedimentos ou rocha (Bathurst 1976, Harris et al. 1985, Tucker e Wright 1990). Aragonita, calcita magnesiana (high magnesium calcite), calcita com baixo teor de magnésio (Jow magnesium calcite) e dolomita são os principais minerais que se depositam como cimento. No caso das rochas estudadas, devido ao forte neomorfismo e à utilização apenas de microscópio petrográfico comum, não serão feitas maiores consideraçōes sobre a mineralogia original, mas sim sobre a morfologia do cimento e que ambiente diagenético representa.

A caracterização dos ambientes diagenéticos de superficie foi baseado no esquema de Longman (1980), que os define como: vadoso; freático de água doce; freático marinho; misto de água doce e marinho. 


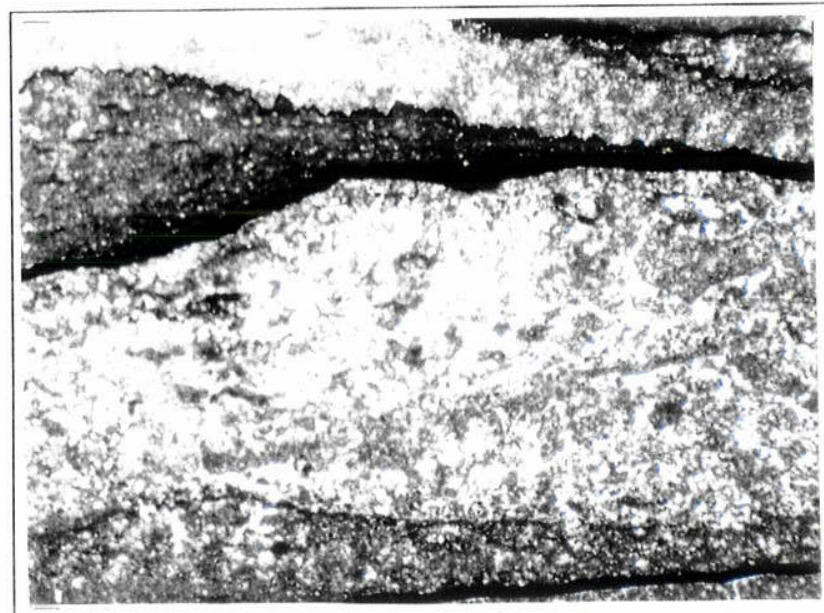

Foto 1 - Fotomicrografia de calcário microbiano críptico onde se observa como estruturas de compactação, estilólitos e dissolution seams L.N. $10 x$

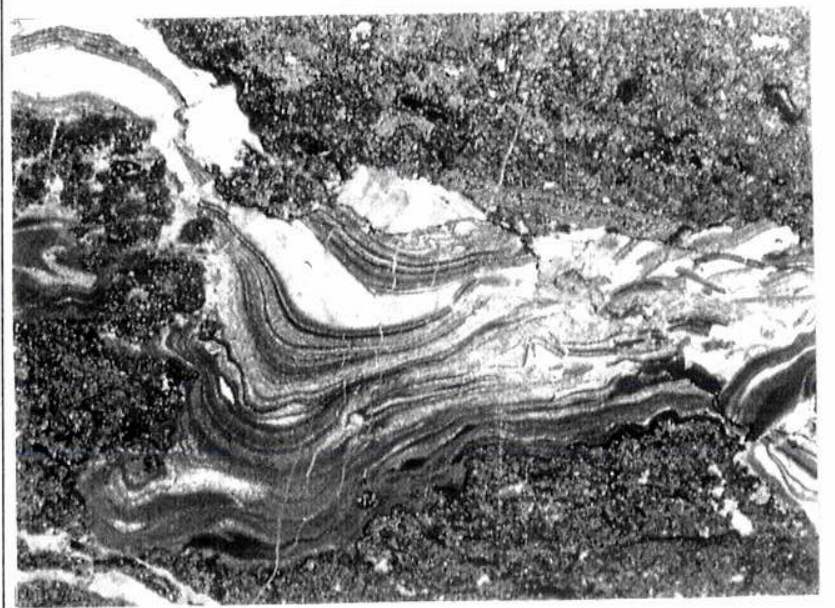

Foto 3 - Fotomicrografia mostrando dissolução, abertura de cavidades e posterior preenchimento L.N. $4 x$

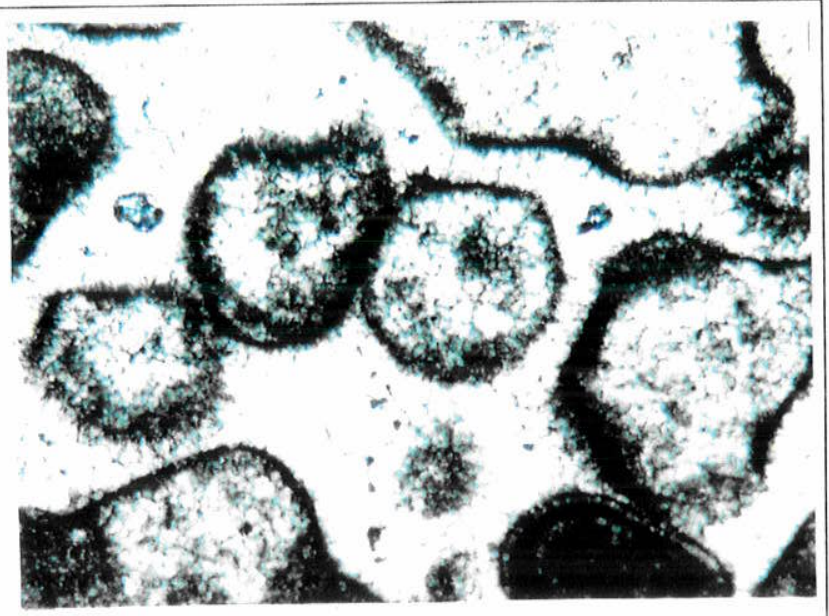

Foto 2 - Fotomicrografia de dolarenito composto por microfitólitos que exibem vestígios de franja isópaca acicular, originalmente aragonítica. X.N. 80x

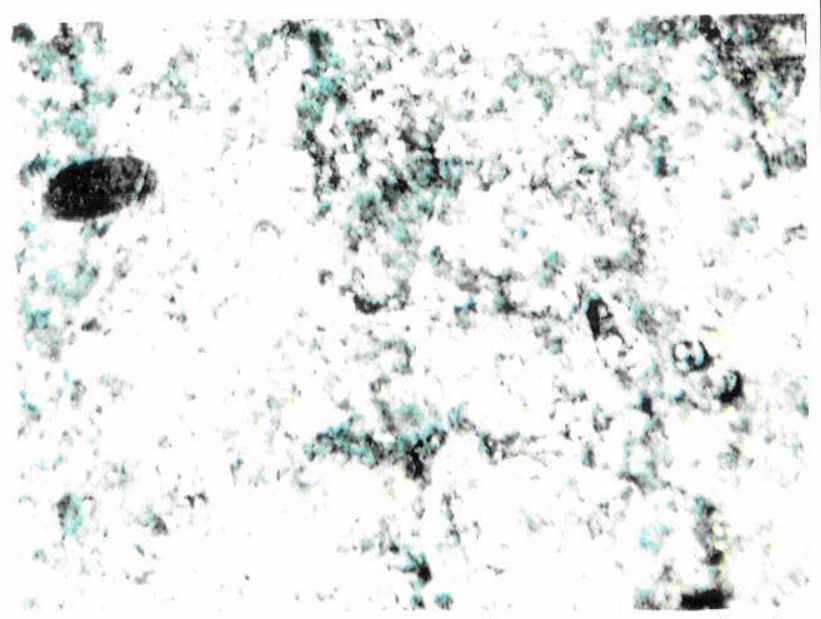

Foto 4 - Fotomicrografia de carbonato neomorfizado, onde se observa apenas vestígios de aloquímicos. X.N. 30x
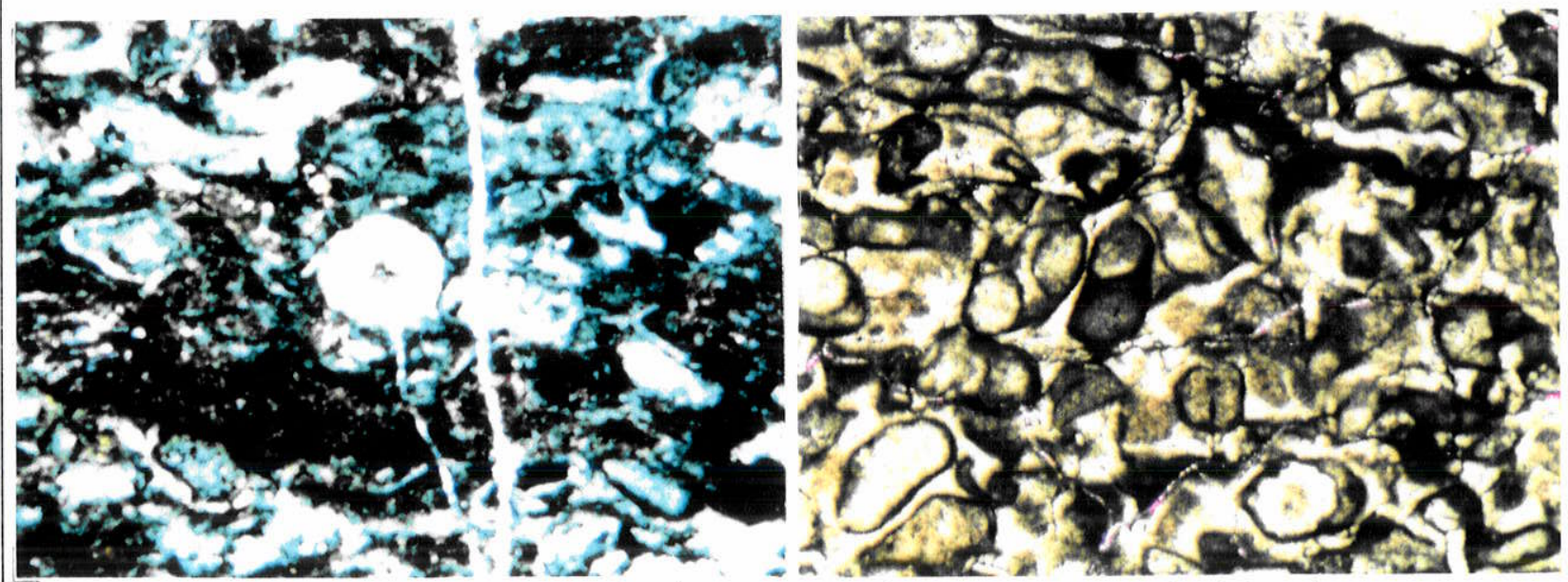

Foto 5 - Fotomicrografia de uma lente de sílex em Foto 6 - Fotomicrografia de dolarenito composto por estromatólito estratiforme onde se observa silicifi- microfitólitos que apresentam dolomitização precoce, cação precoce por microquartzo; o grão do centro é com preservação da textura original. X.N. 40x esferulítico. X.N. $25 x$ 
Em ambiente vadoso, o cimento pode ser do tipo menisco ou gravitacional, também denominado de microestalactítico, e foi raramente observado, em fácies de planície de marés.

Em ambiente diagenético freático de água doce pode não ocorrer cimentação, se o sedimento ou rocha estiver na zona de dissoluçäo; se estiver na zona de circulação ativa de água, o cimento será calcítico, do tipo franja isópaca prismática e mosaico granular.

0 ambiente freático marinho apresenta duas zonas distintas, uma com circulação de água intensa, por ondas, marés ou correntes e outra de estagnação. $\mathrm{Na}$ zona de circulação ocorre a maior parte da cimentação, em franja isópaca, no geral acicular, por deposição de aragonita ou calcita magnesiana (Prancha 59, foto 2). Grainstones e packstones com vestígios de franja isópaca, pouco compactados, evidenciam cimentação precoce, em ambiente marinho franco, com circulação intensa de água.

$\mathrm{Na}$ zona estagnada, onde existe pouca circulação de água nos sedimentos, praticamente não ocorre cimentação, como se observa na Fácies Cll, no Intervalo 3.

Em ambiente misto, de águas salobras, praticamente não ocorre cimentação, sendo mais freqüente ocorrer dolomitização

Em ambiente diagenético de soterramento profundo também pode ocorrer cimentação relacionada a processos de dissolução e reprecipitação. Dolomita euhedral finamente cristalina a microcristalina ocorre dispersa em dissolution seams nas fácies basais do Intervalo 1, e pode representar processo diagenético tardio relacionado a dissolução por pressão (Wanless 1979).

\section{3 - DISSOLUÇÃO}

Dissolução ocorre preferencialmente nas fácies de ambientes perilitorâneos relacionados ao Intervalo 1. Propiciou a abertura de cavidades amplas (Prancha 59, foto 3 ) e a formação de brechas de colapso, em ambiente vadoso, na zona de dissolução (Prancha 28, foto 2).

\section{4 - NEOMORFISMO}

Termo introduzido por Folk (1965), abrange os processos de inversão (de aragonita para calcita), recristalização (de calcita para calcita) e recristalização por pressão.

Como recristalização, o caso mais comum é o da matriz carbonática, micrítica, que recristaliza para microespato e pseudoespato. 
Observa-se na Fácies Cll, do Intervalo 3, grãos micríticos neomorfizados (Prancha 59 , foto 4), o que também ocorre em grãos contidos nas laminações de estromatólitos do Intervalo 3.

\section{5 - SUBSTITUIÇĀO}

Substituição é um processo pelo qual um mineral é substituído por outro, de composição química diferente. Nos carbonatos pesquisados os processos de substituição predominantes são dolomitização, que ocorre de modo expressivo em uma faixa bem delimitada, e silicificaçäo, que ocorre de modo esparso, relacionada a diagênese tardia, ou precoce, em ambiente de planície de marés.

\subsection{1 - Silicificação}

A substituição de carbonatos por microquartzo, com desenvolvimento de nódulos e/ou lentes de silex, foi observada nas fácies $\mathrm{Cm}$ (Intervalo 1), DEes no Intervalo 2, e Cait e $\mathrm{CaCl}$, no Intervalo 3. Nas fácies $\mathrm{Cm}$ e Cait, a silicificação é um processo de diagênese tardia, pois oblitera alguns estilólitos e não preserva as feições originais dos sedimentos. A silicificação que afeta os sedimentos gerados em planícies de maré (Fácies DEes), especialmente em ambiente intermarés, preserva a textura original da rocha (Prancha 59, foto 5) e é de diagênese precoce. Na Fácies DEdc, a dissolução parcial ou total dos oóides, é pós dolomitização e gerou porosidade móldica, a qual foi posteriormente preenchida por megaquartzo (Prancha 25, foto 1).

\subsection{2 - Dolomitização}

A dolomitização na área estudada apresenta-se sob dois tipos principais:

Tipo 1 - A dolomita é finamente cristalina a criptocristalina e preserva a textura original da rocha, o que caracteriza a substituição mímica dos aloquímicos. Esse tipo de dolomitização afeta de modo característico as litologias desenvolvidas em ambientes perilitorâneos (Prancha 59, foto 6).

Assim, a dolomitização que afeta as fácies estromatolíticas, desenvolvidas em ambiente lagunar e de planície de maré dos Intervalos 1 e 2 constitui um mosaico xenotópico, finamente a criptocristalino, e é precoce, sinsedimentar. Possivelmente está relacionada à concentração de sais, por evaporação, em ambiente de águas rasas e com 
pouca circulação. O clima seria semi-árido, o que permitiria a concentração de sais, como denota a presença freqüente de anidrita, embora em pequena quantidade. Foi considerada uma dolomitização do tipo evaporativo (in Tucker 1990).

Tipo 2 - A dolomita é de cristalinidade média a grossa e no geral oblitera a textura original do carbonato. Eventualmente, preserva a forma, mas não a estrutura dos aloquímicos. Afeta as fácies de topo do Intervalo 1, e é representada pelo nivel de dolomito calcitico - Fácies Dcc (Prancha 22, foto 2).

Petrograficamente, o dolomito calcítico apresenta-se como um dolomito cristalino, composto por um mosaico xenotópico a hipidiotópico, com cristais anhedrais a subedrais de dolomita de cristalinidade fina a média. Dispersos nesse mosaico, observam-se cristais esparsos ou compondo pequenos bolsões de dolomita euhedral de cristalinidade grossa a muito grossa. No geral a dolomitização por cristais maiores parece estar relacionada à substituição não mímica de aloquímicos.

Uma mesma litologia pode ter sido duplamente afetada pela dolomitização. Assim, nos dolomitos estromatolíticos da Fácies DEd, do Intervalo 1, os niveis micríticos apresentam-se fortemente dolomitizados, com dolomita finamente cristalina compondo um mosaico xenotópico, com cristais anhedrais a subedrais e não apresentam calcita espática no espaço intercristalino (dolomita do Tipo 1). Os niveis mais claros, com vestígios de aloquímicos, não sofreram dolomitização mímica e apresentam dolomita de cristalinidade média a grossa, em cristais euhedrais a subedrais, freqüentemente zonados, com calcita espática no espaço intercristalino (dolomitização do Tipo 2). As áreas com laminação fenestral apresentam dolomita de cristalinidade grossa que afeta os niveis finamente cristalinos. Após a dolomitização houve dissolução parcial da rocha, como se observa pelas cavidades que apresenta parte de sua parede cimentada por calcita espática.

Os dolomitos estromatolíticos que compöem a Fácies $\mathrm{DEb}$, com brechas de colapso no topo, apresentam-se dolomitizados, com mosaico xenotópico a hipidiotópico, micro a criptocristalino (dolomitização do Tipo 1). Dolomita como cimento ocorre forrando as cavidades e ao redor dos fragmentos das brechas de colapso. Calcita espática ocorre nos espaços intercristalinos e preenchendo as cavidades provenientes da dissolução parcial do dolomito.

Essa dolomitização obliterante é secundária, pós-litificação da rocha, e poderia caracterizar dolomitização por processo do tipo Mixed Water (in Tucker 1990), relacionada à posição das lentes de água doce e salgada, à migração e/ou flutuação da interfácies entre essas duas massas de água, a denominada zona mista, durante evento de flutuação do nível do mar. No caso em questão, a variação da interfacies entre as massas de água 
estaria relacionada à transgressão que originou o Intervalo 2, após o evento de exposição subaérea que afetou as fácies de topo do Intervalo 1. Esse modelo permitiria explicar o ocorrência de níveis regionais de dolomitos estratiformes, não associados a evaporitos, de cristalinidade média a grossa. 0 processo de dolomitização é claramente posterior à diagênese precoce do calcário, e acarreta a perda das características texturais originais da rocha.

Fora desse contexto, a dolomitização é pouco importante, e está relacionada à diagênese tardia, pós soterramento, dos calcários. A dolomita, neste caso, ocorre associada a estruturas de compactação, dissolutions seams e estilólitos, sob a forma de cristais euhedrais polimodais, freqüentemente de cristalinidade muito fina, ou como massas de dolomita barroca limitada por estilólitos, em especial nas fácies basais do Intervalo1. 


\section{7 - MODELO DEPOSICIONAL}

Os carbonatos da região de Arcos foram descritos segundo fácies sedimentares, as quais foram agrupadas em conjuntos faciológicos (Tabela 3). Cada conjunto faciológico é composto por fácies características ou sugestivas de determinado ambiente, o que permitiu a reconstituição dos modelos deposicionais.

A partir da sucessão vertical em que os conjuntos de fácies ocorrem e aplicando-se a Lei de Walther, concluiu-se que as litologias do Grupo Bambuí, na área estudada, registram um grande ciclo regressivo, composto por quatro intervalos, também regressivos, que se estabeleceram após rápidas transgressōes marinhas.

Embora as transgressōes tenham intensidades variadas, é possivel detectar uma tendência a ambientes de águas progressivamente mais rasas em direção ao topo do megaciclo, quando comparados com o ciclo basal. Observa-se ainda que nos sedimentos perilitorâneos podem ser obsenvadas evidências de flutuaçöes menores do nivel do mar.

\section{1 - INTERVALO 1}

As sucessões de fácies observadas no Intervalo 1 foram interpretadas como constituindo um ciclo regressivo (shoaling upward), com sedimentos de águas mais profundas na base e mais rasas no topo (Figura 11), e permitem visualizar como modelo deposicional para o Intervalo 1, o de uma plataforma carbonática do tipo unrimmed shelf (James \& Kendall 1992), composta por uma rampa, talvez do tipo distally steepened (Read 1982), que grada a ambientes perilitorâneos lateralmente diferenciados e bem definidos (Figura 12 ).

Um diastema de natureza erosiva, com evento de exposição subaérea, limita o Intervalo 1.

Nesse intervalo foram caracterizados cinco conjuntos faciológicos. Os conjuntos de fácies A1- Calcário microbiano criptico associado a tempestitos distais (Fácies Cm), B1Tempestitos distais (Fácies Cs) e depósitos rudáceos distais (Fácies Cr) e C1Tempestitos proximais (Fácies $\mathrm{Crg}$, Crf e $\mathrm{CaCrD}$ ), situam-se em rampa externa. 0 Conjunto de Fácies D1 representa corpos arenosos de rampa interna (fácies Cadz e CaDa), e os Conjuntos de Fácies E1 (fácies Dcc e DEcp) e F1 (fácies DEd, DEod e DEb) representam bioconstruções desenvolvidas em ambientes perilitorâneos.

A sucessão de fácies reportada abaixo, registra os eventos geológicos em ordem cronológica, do mais antigo para o mais novo. 
Tabela 3

CONJUNTOS FACIOLÓGICOS

\begin{tabular}{|c|c|c|}
\hline $\begin{array}{l}\text { CONJUNTOS } \\
\text { FACIOLÓGICOS }\end{array}$ & FÁCIES & AMBIENTE \\
\hline A1 & $\mathrm{Cm}+\mathrm{Cr}$ & $\begin{array}{l}\text { Ambiente distal de rampa externa abaixo do nivel de } \\
\text { ação de ondas normais }\end{array}$ \\
\hline B1 & $\mathrm{Cs}+\mathrm{Cr}$ & $\begin{array}{l}\text { Tempestitos distais e depósitos de gravidade em rampa } \\
\text { externa }\end{array}$ \\
\hline C1 & $\mathrm{Crg}+\mathrm{Crf}+\mathrm{CaCrD}$ & $\begin{array}{l}\text { Tempestitos proximais - rampa externa abaixo do nivel } \\
\text { de ação de ondas normais }\end{array}$ \\
\hline D1 & $\mathrm{CaDz}+\mathrm{CaDa}$ & $\begin{array}{l}\text { Corpos arenosos (shoals) - rampa interna, situados } \\
\text { acima do nível de base da ação de ondas normais }\end{array}$ \\
\hline E1 & $D c c+D E c p$ & $\begin{array}{l}\text { Dolomitos estromatolíticos de laguna de plataforma - } \\
\text { biohermas } \\
\text { Ambiente perilitorâneo }\end{array}$ \\
\hline \multirow[t]{2}{*}{$\mathbf{F 1}$} & $D E d+D E d c+D E b$ & $\begin{array}{l}\text { Dolomitos estromatolíticos e não estromatolíticos. } \\
\text { Biohermas e biostromas de ambiente perilitorâneo de } \\
\text { águas agitadas. }\end{array}$ \\
\hline & DI & Calcrete laminado - exposição subaérea \\
\hline $\mathbf{F 2}$ & $\begin{array}{l}\text { DEes + intercalações } \\
\text { não estromatolíticas }\end{array}$ & $\begin{array}{l}\text { Dolomitos estromatolíticos de planícies de marés } \\
\text { cíclicas. Biostromas e intercalações de dolomitos não } \\
\text { estromatolíticos. Inframaré a intermaré alta }\end{array}$ \\
\hline G3 & Cait +CE & $\begin{array}{l}\text { Calcarenitos intraclásticos e biohermas estromatoliticos } \\
\text { semelhantes a patch reef de plataforma externa }\end{array}$ \\
\hline H3 & $\begin{array}{l}\mathrm{CaOo}+\mathrm{CE}+\mathrm{Can}+ \\
\mathrm{CaCl}\end{array}$ & $\begin{array}{l}\text { Biohermas estromatolíticos tipo patch reef e } \\
\text { intercalações de calcarenitos e calcilutitos de middle } \\
\text { shelf. Barreira arenosa, oolitica (shoal) } \\
\text { Tempestitos proximais de águas rasas }\end{array}$ \\
\hline F3 & $\mathrm{Cll}+\mathrm{CsI}+\mathrm{MRG}$ & $\begin{array}{l}\text { Calcilutitos escuros e calcissiltitos de planície de maré } \\
\text { restrita; calcissiltitos com intercalações de calcilutitos } \\
\text { argilosos e depósitos de tempestade; margas em } \\
\text { ambiente de intermaré }\end{array}$ \\
\hline G4 & Cait + CE & $\begin{array}{l}\text { Calcarenitos intraclásticos, biohermas estromatoliticos } \\
\text { semelhantes a patch reef e calcarenitos neomorfisados } \\
\text { de plataforma externa }\end{array}$ \\
\hline H4 & Can + Caoo & $\begin{array}{l}\text { Calcarenitos neomorfizados e barreiras arenosas, } \\
\text { ooliticas (shoal) em Middle Shelf }\end{array}$ \\
\hline
\end{tabular}




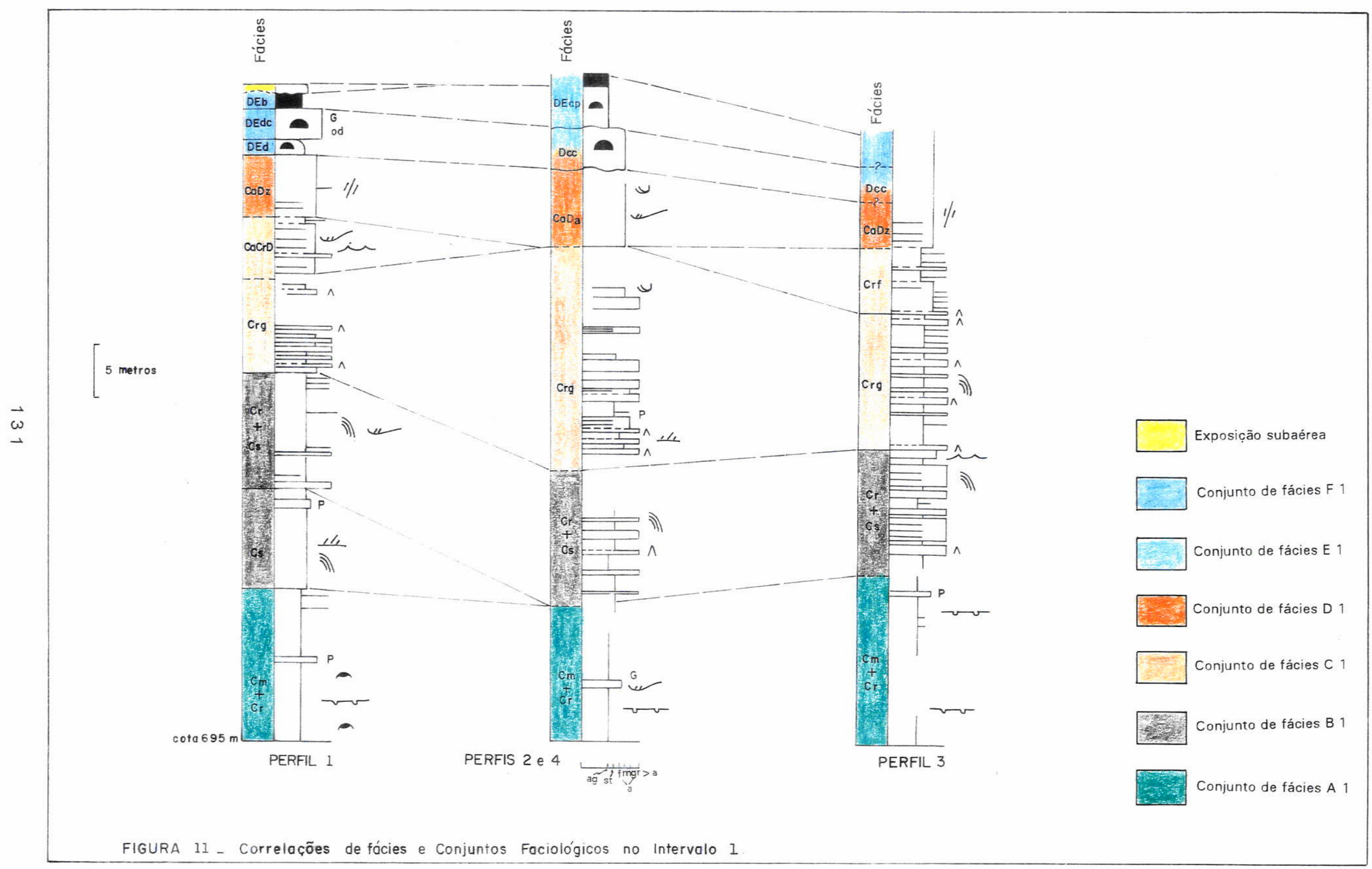




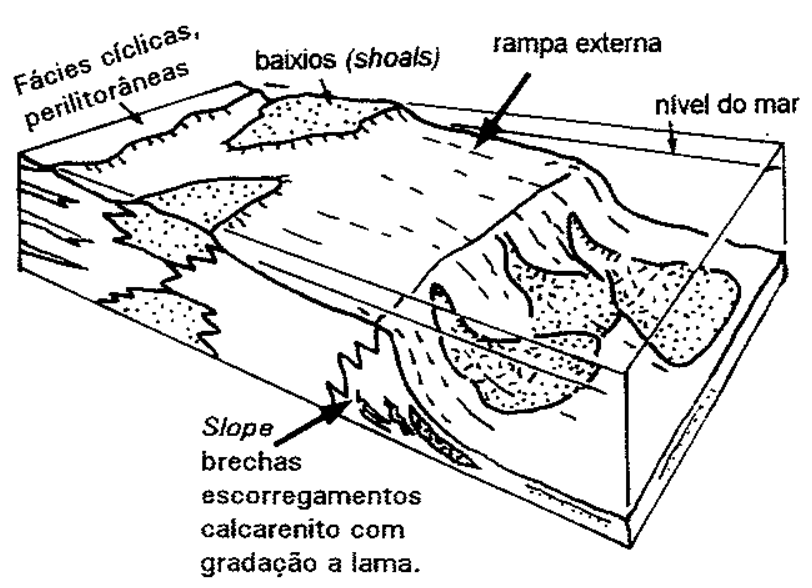

Bloco-diagrama de uma rampa carbonática distally steepened (Read 1982)

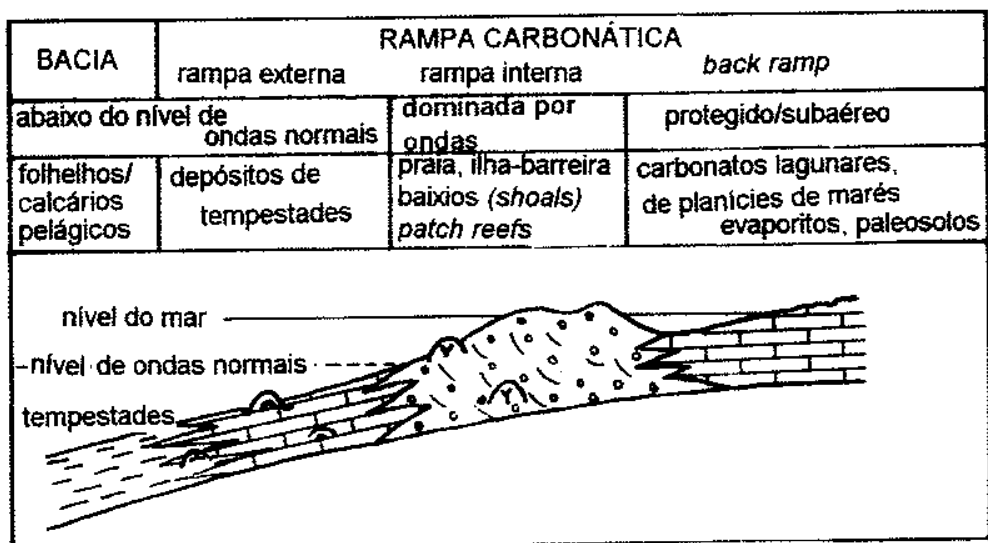

Modelo deposicional de uma rampa carbonática (Tucker 1990)

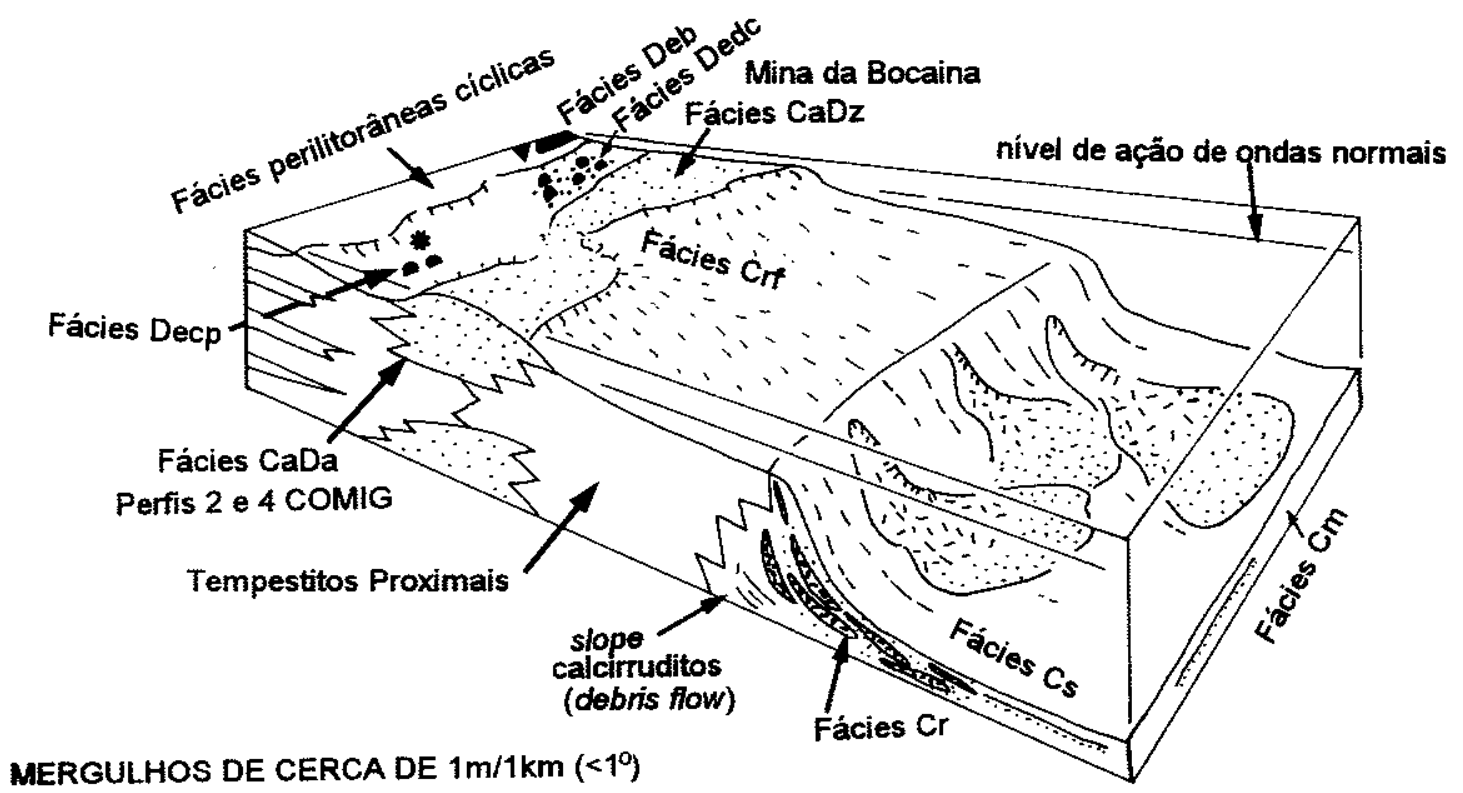


A Fácies $\mathrm{Cm}$, basal, é a mais distal, tendo se desenvolvido em ambiente de águas profundas, distante da linha de costa, mas com luminosidade suficiente para permitir o desenvolvimento de vida (fotossíntese). Constitui extenso biostroma formado leito a leito, a partir do trapeamento de sedimentos e/ou precipitação mineral, em grande parte biologicamente controladas por microorganismos bentônicos, possivelmente cianobactérias. O fato de o calcário apresentar microfábrica compativel com construções microbianas, com vestígios de microfósseis, mas sem feições macroscópicas distintivas, permite classifica-lo como calcário microbiano críptico (Riding 1991).

O fato de apresentarem laminoid fenestral fabric (Monty 1976), com laminação fenestral, microfábrica micrítica, grumosa ou peloidal, associado à litificação precoce, sinsedimentar, é indicativo que esses carbonatos sejam ao menos em parte construídos por microorganismos; a presença de microestruturas semelhantes às observadas em carbonatos microbianos de águas rasas (Aitken 1967), e de formas que lembram vagamente Renalcis, reforçam essa hipótese.

O aspecto planar que o calcário microbiano críptico apresenta, poderia ser explicado a partir da proposição de Pratt (1982) para a formação de mud-mounds com estrutura laminar (laminar framework). Segundo o autor, a estrutura laminar, com niveis planares, se desenvolveria a partir da existência de tapetes microbianos lateralmente extensos, que eram periódicamente soterrados devido ao aporte de sedimentos associados a fluxos episódicos. Assim que o ambiente se normalizava, os níveis microbianos voltavam a crescer, com rápida cimentação, em ambiente de inframaré com baixa taxa de sedimentação. Processos semelhantes poderiam ter atuado durante a formação dos níveis de calcário microbiano críptico, pois os mesmos constituem leitos planares mais ou menos extensos, com cimentação precoce e desenvolveram-se em ambiente distal com baixa taxa de sedimentação, mas que recebia aportes esporádicos de material lamoso. Esse material fino provocaria o soterramento ou a contaminação das construções microbianas, dificultando seu desenvolvimento; aportes freqüentes de material externo resultariam nos delgados leitos microbianos com material lamoso associado ou nos niveis lamosos; em épocas normais, com baixa taxa de sedimentação e sem aporte de argilominerais, os niveis microbianos se desenvolveriam mais facilmente e originariam os niveis com laminação fenestral, mais espessos e de maior continuidade lateral quando comparados aos delgados leitos que compõem os niveis mais argilosos. $O$ ambiente apresentaria sempre alguma circulação de água, pois as cavidades não apresentam sedimento interno, estão cimentadas por calcita espática, o que presume circulação de água nas cavidades e muito raramente se observa a presença de cristais de pirita. 
Quanto ao tipo de estrutura que representariam, os calcários microbianos crípticos apresentam algumas semelhanças com mud-mounds, embora não possam ser considerados estritamente como tais. Como fatores comuns, tem-se o fato de que ambos se situam em posição distal na plataforma carbonática e são lamosos; possuem ainda aspectos texturais e microestrutura comuns, como laminação fenestral, associado ao fato de ambos apresentarem características de carbonatos criptalgais (Aitken 1967). Mas o calcário microbiano criptico não apresenta stromatactis, embora possua cavidades que se assemelham, mas estas são microscópicas e não macroscópicas; o acamamento é horizontal, à excessão do Perfil 3 onde no geral se observa mergulhos da ordem de $10^{\circ}$ que gradativamente passam a suborizontais em direção ao topo da fácies, o que não é característico de mud-mounds onde as camadas no geral apresentam altos angulos de mergulhos; mud-mounds apresentam ainda relevo expressivo, com espessuras da ordem de dezenas a poucas centenas de metros, constituindo biohermas, ao contrário do que se observa no calcário microbiano, cuja extensão areal é muito maior que a espessura observada.

Embora distante da linha de costa, esporadicamente a Fácies $\mathrm{Cm}$ era atingida por fluxos decorrentes de tempestades muito fortes ou de longa duração, que aportavam sedimentos, bem como arrancavam e remobilizavam fragmentos do assoalho marinho. 0 fato de os calcários microbianos terem atuado como fonte de intraclastos para os calcarenitos e calcirruditos adjacentes, indica que foram esporadicamente afetados por correntes e/ou ondas geradas por tempestades.

Os calcarenitos e calcirruditos que ocorrem nos perfis 1 e 3, constituem depósitos distais de tempestades, como descritos por Aigner (1985), com delgados niveis intraclásticos em meio a sedimentos de águas profundas. Os calcarenitos encontrados no Perfil 2 também são reflexo de tempestades, mas representam ou o registro de eventos episódicos múltiplos, ou de um único evento de alta intensidade ou longa duração, pois apresentam caracteristicas de depósitos proximais de tempestades, como laminaçōes cruzadas por ondas e marcas onduladas truncantes de baixa amplitude e grande comprimento de onda, em meio a calcários argilosos de ambiente distal. Essas características, comuns em tempestitos proximais, são pouco freqüentes em tempestitos distais.

Lateralmente aos calcários microbianos crípticos, depositaram-se em águas progressivamente mais rasas, os sedimentos que compõem o Conjunto de Fácies B1, onde tempestitos distais (Fácies Cs) e depósitos rudáceos distais ( Fácies $\mathrm{Cr}$ ) gradam lateralmente a tempestitos proximais, representados pelo Conjunto de Fácies C1 (fácies 
$\mathrm{Crg}, \mathrm{Crf}$ e $\mathrm{CaCrD}$ ). 0 modo característico de sedimentaçäo dessas fácies é o de eventos episódicos, caracterizado pelo afluxo súbito de sedimentos, com rápida deposição, em rampa externa.

$\mathrm{Na}$ Fácies Cs predominam calcissiltitos com laminaçöes plano-paralelas a onduladas, e cruzadas. Sua deposição se deu em águas profundas, durante fases de abrandamento das tempestades. Segundo Kreisa e Bambach (1982), sedimentos finos, granulação silte e areia, säo transportados durante a fase de alta energia das tempestades e depositados à medida que os fluxos perdem energia. A laminaçäo paralela por si só indica deposição a partir de uma densa suspensão; as laminaçōes cruzadas seriam causadas por rápida deposição, também a partir de suspensöes.

Quanto ao grau de proximalidade desses tempestitos, a baixa relação calcarenito/calcissiltito observada nessa fácies é indicativa de depósitos distais de tempestades, pois segundo Aigner (1985), a proporção de finos aumenta consideravelmente à medida que se afasta da linha de costa. A presença de argilominerais na porção basal da fácies corrobora a deposição em ambiente distal, situado abaixo do nivel de ação de ondas normais.

A Fácies $\mathrm{Cr}$, composta por calcirruditos em contato nítido com calcissiltitos e calcário microbiano críptico, foi considerada como tendo sido depositada em ambiente distal, de águas claras, com baixa taxa de sedimentação, abaixo do nivel de ação de ondas normais. Seu desenvolvimento poderia estar estaria relacionado à ação de fluxos turbulentos, possivelmente decorrentes de eventos de tempestades, em áreas de quebra de relêvo da rampa, o que resultaria em depósitos gerados por processos gravitacionais, talvez do tipo debris flow.

No geral, depósitos gerados por fluxos gravitacionais apresentam contato basal planar, com raras marcas de sola e contato superior nítido, näo gradacional. Internamente são mal selecionados e no geral não são organizados (Enos \& Moore 1983; Coniglio \& Dix 1992). Os calcirruditos podem ser sustentados pela matriz (floatstones) ou pelos clastos (rudstones), mas é importante ressaltar que a matriz é passivel de sofrer modificações pela formaçäo de estilólitos, o que provoca alteraçöes na textura deposicional e pode resultar em clastos condensados ou com contatos interpenetrativos por estilólitos. Todas as características acima descritas são de depósitos relacionados a fluxos gravitacionais do tipo debris flow e säo semelhantes às descritas na Fácies $\mathrm{Cr}$.

No caso de uma rampa distally steepened, o fato de a quebra de relêvo ocorrer a muitos quilometros da linha de costa, faz com que os intraclastos que compöem os calcirruditos de zona de quebra da rampa sejam derivados das litologias adjacentes, sem 
mistura com materiais gerados em ambientes costeiros (Read 1982); isso explicaria a presença de calcirruditos compostos por intraclastos derivados de fácies distais, como calcissiltitos e calcário microbiano criptico, os quais foram erodidos e originaram clastos que foram redepositados nas proximidades das áreas-fonte, com pequeno transporte lateral.

O fato de os calcirruditos e calcissiltitos constituirem pares, sempre em contato nítido, não gradacional, indica que os niveis brechóides estiveram expostos, por algum tempo, no assoalho oceânico, antes da deposição dos calcissiltitos, o que é sugestivo de ambiente com baixa taxa de sedimentação.

A colonizaçäo dos calcirruditos e calcissiltitos por tapetes microbianos, indica presença de águas claras, com luminosidade suficiente para permitir o desenvolvimento de bioconstruçöes, e reforça a evidência de ambiente com baixa taxa de sedimentação. Os niveis microbianos se desenvolveriam em épocas de calmaria, quando a baixa taxa de sedimentação e a ausência de movimentação dos sedimentos de fundo, permitiriam a colonização do leito oceânico por microorganismos, com rápida litificação.

Lateralmente aos depósitos distais, situa-se o Conjunto de Fácies C1, constituido por tempestitos proximais. A Fácies Crg, composta por niveis rudáceos com granodecrescência ascendente, apresenta características de tempestitos proximais tais como variação lateral de espessura, gradação normal e laminaçōes cruzadas. A maior heterogeneidade dos intraclastos, em termos texturais e a ocorrência de clastos policíclicos, embora raros, são também indicativos de ambientes proximais.

Os niveis com gradação normal, constituem depósitos gerados por eventos de alta energia, no caso, tempestades; a gradação ocorre devido à suspensão diferencial de seus componentes nos fluxos, os quais, nas fases de abrandamento, com perda gradual de intensidade, depositam sedimentos cada vez mais finos.

As sucessöes com granodecrescência ascendente, compostas por leitos distintamente segregados em função de sua granulometria e com limites abruptos, são descritas por Kreiza \& Bambach (1982), e também consideradas como produto de eventos de tempestades.

Nessa fácies observa-se que os depósitos de tempestade exibem variações, talvez em função da paleogeografia local, pois nos perfis 2 e 5 , a presença de níveis mais espessos e com clastos maiores, amalgamados, em direção ao topo da fácies, poderia sugerir uma situação semelhante aos offbank spillover lobes (Aigner 1985), onde depósitos proximais de tempestades fazem contato, em direção ao topo, com corpos arenosos de águas rasas (Fácies $\mathrm{CaDa}$ ), e para a base, com sedimentos de águas profundas (Fácies 
Cr e Cs). Na Mina da Bocaina, a Fácies Crg possivelmente teria sido depositada em águas mais profundas, pois grada para a Fácies $\mathrm{CaCrD}$, com características de tempestitos proximais clássicos.

A Fácies Crf ocorre de modo localizado no Perfil 3 e grada no topo para corpos arenosos de águas mais rasas, sem que se observe ai os clássicos niveis proximais de tempestades. Os depósitos encontrados nessa fácies têm como característica principal a presença de niveis brechóides que flutuam em matriz arenosa ou lamosa. Eventualmente, ocorrem associados a niveis conglomeráticos de base erosiva e com granodecrescência ascendente. Essas características são semelhantes às descritas por Fairchild (1988), para - Type $C$ beds, onde faz referência a leitos de textura diamictitica, com clastos boiando em matriz lamosa. O autor considera que esses leitos representam áreas localizadas, onde ocorre intenso retrabalhamento dos sedimentos, com transportes rápidos e de curta duração, sob a forma de fluxos gravitacionais com alta densidade de sedimentos, e os associa à ação de tempestades. Segundo Einsele (1991), em alguns casos, fluxos de gravidade carregados de sedimentos podem ocorrer em áreas com mergulho tão suave quanto $0,1^{\circ}$ a $1^{\circ}$, o que torna possivel sua ocorrência em condiçōes de baixa declividade, como em uma rampa. Como os conglomerados e niveis brechóides da Fácies Crf também ocorrem associados a tempestitos e apresentam algumas características de fluxos de sedimentos por gravidade, como serem sustentados por matriz de granulação fina a média e terem os clastos, de dimensōes variáveis, "flutuando" nessa matriz, foram considerados como tendo sido gerados por fluxos gravitacionais relacionados a processos de tempestades.

A Fácies CaCrD, a mais proximal do Conjunto de Fácies C1, foi depositada abaixo do nível de ação de ondas normais. A presença de niveis intensamente amalgamados, compondo ciclos com granodecrescência ascendente, é indicativa de leitos proximais de tempestade, e embora não se tenha definido estratificação cruzada hummocky (HCS), os demais indicadores utilizados para proximalidade em tempestitos (Aigner 1982 e 1985 , Einsele \& Seilacher 1982, Seilacher \& Aigner 1991, entre outros), também convergem para uma posição proximal. Os diversos niveis apresentam base erosiva, são predominantemente arenosos e internamente apresentam a seqüência clássica, embora raramente completa, de estruturas sedimentares presentes em tempestitos proximais: laminaçōes plano-paralelas, laminaçōes cruzadas por ondas, marcas onduladas, eventualmente contendo laminaçōes plano-paralelas no topo, quando ocorre material fino fechando o ciclo. Essa sucessão resulta, segundo Aigner (1985), da ação de fluxos 
combinados em fase de perda de energia (waning combined flow), onde o componente de corrente perde energia mais rapidamente que a componente de onda.

A presença de intraclastos carbonáticos texturalmente heterogêneos, com clastos policíclicos, também é indicativa de depósitos proximais de tempestades, bem como a maior freqüência de laminação cruzada por onda e marcas onduladas.

A presença, em blocos rolados, de espessos níveis brechóides, em contato nítido por calcarenitos com estratificação cruzada acanalada de médio porte, sugere a existência local de canais, embora não se tenha observado indicação de fluxos unidirecionais em afloramentos.

Em ambiente de rampa interna, situado acima do nivel de ação de ondas normais, depositaram-se as fácies $\mathrm{CaDz}$ e $\mathrm{CaDa}$ (Conjunto de Fácies D1), as quais constituem corpos carbonáticos arenosos dispostos paralelamente à linha de costa (nearshore sand belf), e constituem um modelo de barreira regressiva.

No Perfil 4, na mina em atividade da COMIG, os corpos arenosos da Fácies CaDa, constituiam barreira efetiva, talvez emergentes, do tipo ilha-barreira (beach barrier). As estratificaçōes cruzadas por ondas, com truncamentos suaves e de grande amplitude, clássicas de antepraia (shoreface), são cortadas próximo ao topo, por cruzadas acanaladas de pequeno porte. Essas características indicam variação de ambiente de águas mais profundas, de antepraia, para águas mais rasas, na zona intermarés. 0 conglomerado com gradação normal poderia representar o registro proximal de um depósito de tempestade.

No Perfil 1, na Mina da Bocaina, o corpo arenoso, representado pela Fácies $\mathrm{CaDz}$, constituia um banco submerso; a presença de estratificações cruzadas por onda e cruzadas planares em sets tabulares decimétricos sugere deposição como sand waves marinhas ou uma série de meganipples formando corpos arenosos.

No Perfil 3, como a seção acessivel é pequena, não é possível fazer inferências quanto à posição da barreira arenosa em relação ao nivel do mar. A parte observável, no entanto, apresenta em sua porção basal, características semelhantes às que ocorrem no Perfil 1, com estratificações cruzadas planares.

A presença de barreiras arenosas situadas a diferentes profundidades, levou à individualização de ambientes de sedimentação lateralmente diferenciados em relação à linha de costa.

No Perfil 4, os estromatólitos basais da Fácies DEcp desenvolveram-se em uma laguna rasa, em ambiente de inframaré de baixa energia, como atestam a presença de lama carbonática, a pouca laminação fenestral observada nos estromatólitos e a ausência 
de feições de ressecação. Os estromatólitos de topo apresentam características de intermaré, com niveis fraturados, possivelmente por ressecaçäo, e laminação fenestral.

Na Mina da Bocaina (Perfil 1), os calcarenitos dolomíticos, por constituirem um corpo submerso, permitiram o desenvolvimento de fácies de ambiente perilitorâneo de alta energia (Conjunto de Fácies F1), com estromatólitos métricos associados a dolarenito ooidal. $\mathrm{O}$ bioherma estromatolítico com formas dômicas de pequeno porte(Fácies Ded) desenvolveu-se em área protegida da ação de ondas, atrás da barreira arenosa (Fácies CaDz), em ambiente de inframaré. A existência, na base do bioherma, de delgados niveis micríticos ondulados, e de intraclastos micríticos, derivados de tapetes microbianos semelhantes a algal chips, paralelamente acamadados, indicam que o ambiente não era sujeito à ação de ondas fortes. Essa proteção gerou um ambiente de águas calmas, o que permitiu a colonização do substrato por microorganismos.

Em ambiente de águas rasas e agitadas, desenvolveram-se os estromatólitos dômicos de grande porte, associados a dolarenitos ooidais ( Fácies DEdc). Segundo Hoffman (1976), o relevo das estruturas estromatoliticas é proporcional à intensidade da ação das ondas. Estromatólitos de grandes dimensões e relevo alto se desenvolvem atualmente em ambientes de alta energia, expostos à ação de ondas, em área de inframaré a intermaré baixa. A ação de ondas evita a acumulação dos sedimentos entre as colunas permitindo que tenham relevo. Colunas alongadas e coalescentes, indicam áreas mais internas, mais próximas à costa, sob ação de ondas mais fracas. Assim, os estromatólitos dômicos de grande porte, teriam se desenvolvido em ambiente de inframaré, possivelmente em águas rasas e agitadas como indica a presença de ooides, e sujeitos à ação de fluxos gerados por tempestades, com intraclastos aprisionados nas laminações estromatolíticas. Os estromatólitos alongados, coalescentes, se situariam mais próximos à costa, em áreas de inframaré a intermaré baixa e sofreriam a ação de ondas mais fracas.

A presença de estromatólitos associados a dolarenitos ooidais, característicos de ambiente de águas rasas e agitadas, exclui a presença de ambiente lagunar em direção à linha de costa e confirma que a barreira formada pelos calcarenitos dolomíticos, na Mina da Bocaina, não era emergente, e não afetava de modo significativo o regime local de alta energia. Se os calcarenitos da Fácies $\mathrm{CaDz}$ formassem uma barreira emergente, efetiva, não existiriam condiçōes de águas rasas e agitadas, necessárias para o desenvolvimento de grãos ooidais.

Lateraimente aos estromatólitos que ocorrem associados dolarenitos ooidais, desenvolveu-se a Fácies DEb, composta predominantemente por estromatólitos 
estratiformes possivelmente em área de intermaré média a alta. Estromatólitos estratiformes no geral desenvolvem-se em áreas onde a ação de ondas e os efeitos das marés são fracos, permitindo a colonização de areias soltas por esteiras microbianas (Hoffman 1976).

Com relação ao clima, a presença subordinada de cristais de evaporitos sugere que o clima era preferencialmente semi-árido.

O dolomito com laminações irregulares (Fácies DI) ocorre imediatamente acima da zona que contém as brechas de dissolução ou de colapso na Fácies DEb . Não apresenta características marcantes de ação de ondas e está fortemente dolomitizado, com obliteração da textura original da rocha. Talvez possa representar um nivel de calcrete laminado, resultante de processos pedogenéticos relacionados ao evento de exposição subaérea que afetou a plataforma carbonática.

O evento de exposição subaérea afetou as fácies de topo do intervalo 1 e produziu, além do possivel nivel de calcrete laminado, a dissolução de grãos, a abertura de cavidades, e a formação de brechas de colapso.

\section{2 - INTERVALO 2}

É predominantemente estromatolítico, sendo composto em sua maioria por dolomitos estromatolíticos que constituem biostromas e apresentam intercalações granulares, não estromatolíticas. Constitui o registro de um ciclo regressivo, composto por várias sucessões menores, também regressivas, em ampla plataforma carbonática de baixa declividade. Registra a acreção vertical e lateral de uma planície de maré que se estabeleceu após transgressão marinha de pequena amplitude, que se seguiu ao evento de exposição subaérea.

Os biostromas constituem sucessões regressivas métricas, onde se observam pequenas flutuações do nivel do mar, com desenvolvimento de pequenos ciclos de sedimentação, que apresentam águas mais profundas na base e mais rasas no topo.

A transgressão inicial que propiciou a instalação do Intervalo 2, levou ao estabelecimento de ambiente de águas não muito profundas, claras e agitadas, com desenvolvimento de planícies de maré em direção à linha de costa. 0 clima seria semiárido, como demonstra a presença de evaporitos.

Em ambiente de inframaré, com águas claras e agitadas, sem aporte de lama, mas com aportes esporádicos de grãos, possiveimente associados a tempestades ou marés de maior energia, teriam se desenvolvido os estromatólitos em "maciços arborescentes", os 
quais talvez constituissem construçöes recifais, o que resultou em ambiente mais protegido, onde se desenvolveram os estromatólitos estratiformes a pseudocolunares que os recobrem (cota 766 metros), em águas mais rasas e sujeitas a concentração de sais, como evidenciado pela presença de anidrita.

O dolarenito constituído por microfitólitos, com estratificaçöes cruzadas por ondas, formou-se em ambiente de águas rasas e algo agitadas, em condiçōes de energia intermediária: nem tão alta que propiciasse o desenvolvimento de oólitos, nem tão baixa, que permitisse a colonização dos sedimentos por esteiras microbianas, como sugerem Swett \& Knoll (1985).

Lateralmente, em ambiente de intermaré, atingindo intermaré alta, teriam se desenvolvido os estromatólitos estratiformes que apresentam laminação fenestral e gretas de ressecação.

O nivel de calcirrudito provavelmente representa o registro de ligeira flutuação do nivel do mar, pois os estromatólitos situados acima (cota 767,5), apresentam características ainda de intermaré, mas algo diferentes das que se observa nos estromatólitos situados abaixo dessa cota. Desaparecem as evidências de ressecação nos estromatólitos, e observa-se a presença de feiçōes geopetais, diagênese vadosa, o que associado à ausência de dissecação, é sugestivo de ambiente intermaré, de baixa energia. Os estromatólitos estratiformes constituiriam esteiras microbianas, desenvolvidas em uma planicie de maré calma.

$\mathrm{Na}$ cota 770 metros, os estromatólitos possuem caracteristicas sugestivas de ambiente de intermaré, talvez intermaré alta, de maior energia que os niveis anteriores. Exibem laminação fenestral e niveis compostos por bioclastos estromatolíticos imbricados, de texturas diversas, estabilizados por tapetes microbianos. Representam a parte superior de uma sucessão regressiva.

Os estromatólitos observados na cota 770,5 metros desenvolveram-se em ambiente de águas calmas, em ambiente de inframaré a intermaré. Não apresentam feiçōes de ressecação, nem laminação fenestral, e exibem aportes freqüentes de gräos e lama, que são estabilizados por niveis microbianos. Caracterizam a parte basal de um novo ciclo.

O espesso pacote de packstone (cota 771 metros) com estratificação cruzada por ondas foi depositado em ambiente de inframaré. O delgado nível de packstone mal selecionado, possivelmente representa um depósito de tempestade.

Para o topo do intervalo, embora as unidades não sejam observáveis a curta distância, a permanência do estilo de sedimentação, com estromatólitos predominantemente estratiformes, é indicativa de planícies de maré. 
No Perfil 4, os dolomitos laminados desenvolveram-se em inframaré, em ambiente de águas calmas, onde niveis arenosos, possivelmente relacionados a fluxos gerados por tempestades, foram estabilizados por tapetes microbianos. Como a influência do meio ambiente era preponderante, as esteiras microbianas atuaram mais como estabilizadoras dos sedimentos do que como construtoras, pois não se observa aí a presença de estromatólitos. Os dolomitos laminados são correlacionáveis aos biostromas basais que ocorrem no Perfil 1.

No Intervalo 2, embora tenham sido descritas várias sucessões menores, indicativas de oscilações do nivel do mar, não se conseguiu reproduzir o padrão característico de uma sucessäo regressiva assimétrica do tipo inframaré, intermaré e supramaré (Pratt et al. 1992). As sucessőes apresentam sempre tendência regressiva, mas em alguns casos, como se observa nos estromatólitos que ocorrem acima do nivel de dolorrudito (cota 767,5 metros), percebe-se que houve mudança no meio ambiente, com ligeira flutuação do nivel do mar, mas o ambiente continua a ser intermaré, sem que se tenha observado a fase de inframaré. Também nas sucessões onde foi possível investigar com maior detalhe, não se observou a presença de sedimentos característicos de supramaré, apenas de intermaré alta.

\section{3 - INTERVALO 3}

Foi considerado como tendo sido depositado em uma plataforma carbonática progradante, possivelmente do tipo rimmed shelf (Figura 13). Constitui um ciclo regressivo e apresenta semelhanças com ciclos Oolite Grainstones e Lime mud- Sabkha Wilson 1975), característicos de períodos de sedimentação puramente carbonática em plataformas cratônicas rasas e amplas.

Ciclos Oolite Grainstone apresentam no topo, ou próximo ao topo, uma fácies principal composta por um grainstone freqüentemente oolítico, que pode passar para fácies lagunares, eventualmente com gradação lateral, em direção à linha de costa, para ciclos de tipo Lime mud-Sabkha. Ciclos deste último tipo são característicos de ambientes de baixa energia, têm no topo carbonatos finamente laminados de planície de maré ou sabkhas evaporíticas e não apresentam evidências de exposição aérea prolongada, sendo recobertos por leitos marinho-franco, que constituem a base do intervalo subsequente.

No Intervalo 3 foram identificados 3 conjuntos de fácies, que indicam ambientes deposicionais de: Plataforma Externa - Conjunto de Fácies G3 (Fácies Cait e CE ); de 


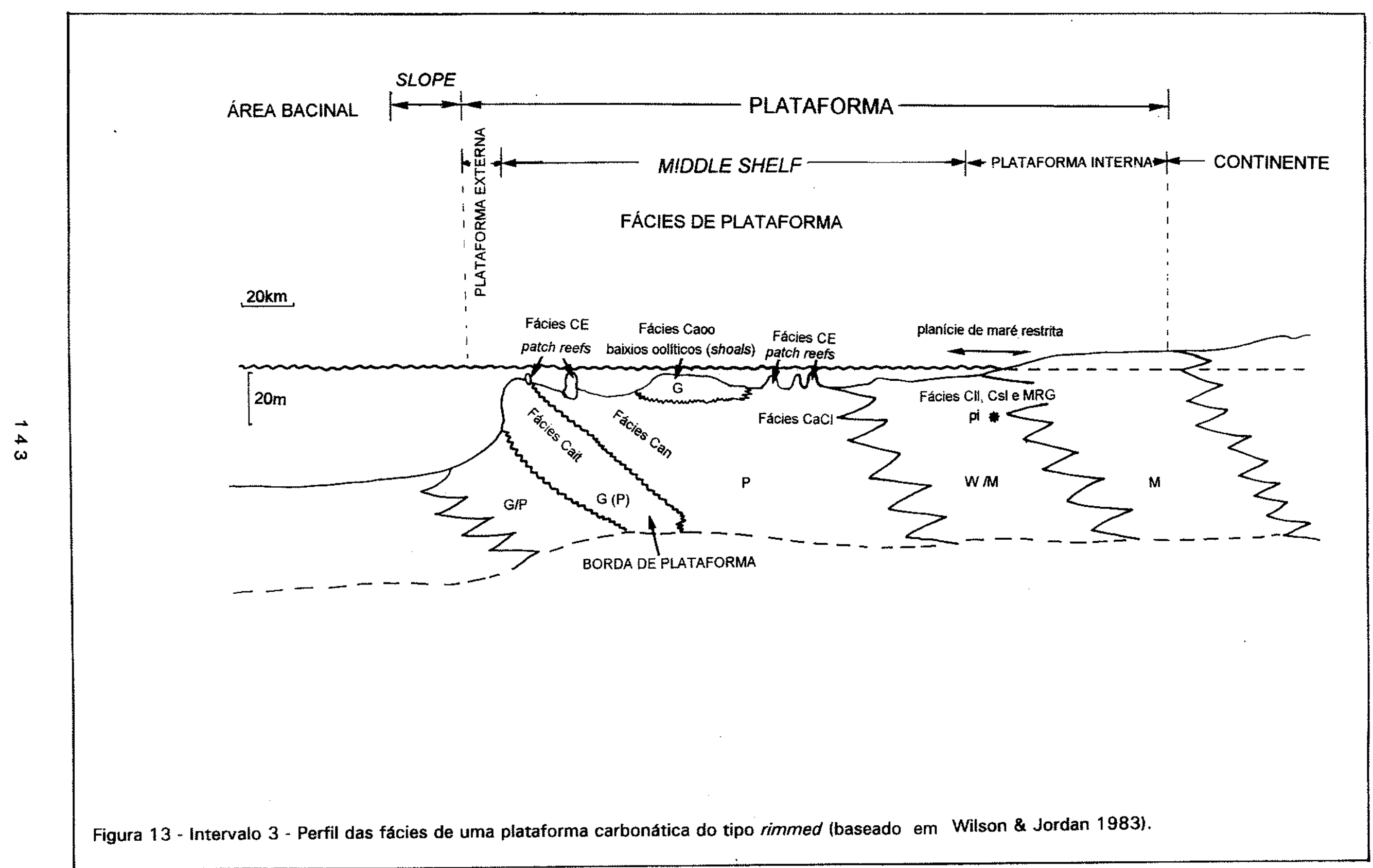


Middle Shelf - Conjunto de Fácies H3 (Fácies Can, Caoo, CE e CaCl); o Conjunto de Fácies F3 (Fácies Cll, Csl e MRG), representa depósitos de plataforma interna.

No Conjunto de Fácies G3, a Fácies Cait constitui a parte basal, transgressiva, do ciclo Oolite Grainstone. Representa a fase de inundação extensiva da plataforma carbonática. A redução gradual da espessura das camadas basais em direção ao topo e o limite entre ciclos por superficies de erosão, no caso provocadas por ondas, seriam características da fase transgressiva dos ciclos e ocorreriam abaixo do limite da ação de ondas normais (Wilson 1975.).

O fato de os biohermas estromatoliticos terem se desenvolvido sobre sedimentos arenosos, sugere águas não muito agitadas, sem revolvimento constante da areia, possivelmente abaixo do nivel de ação de ondas normais e/ou a presença de crosta estável, litificada, do tipo hardground, que talvez pudesse estar representada pela delgada superficie de topo da Fácies Cait. Ambas as situações permitiriam a colonização da superficie por estromatólitos, com desenvolvimento de biohermas.

Os biohermas estromatolíticos dispersos próximo à borda da plataforma constituiam pequenas construçōes recifais semelhantes a patch reefs e desenvolveram-se em ambiente de inframaré, como se deduz pela ausência de feições de ressecação nos estromatólitos. Eventualmente, eram afetados por fluxos gerados por tempestades, que aportavam material granular, parte do qual ficou aprisionada nas laminaçöes estromatolíticas; também quebravam os estromatólitos, gerando brechas constituidas por seus bioclastos, que podem ter sido depositadas in situ.

Em ambientes ainda de inframaré, de águas calmas, teriam se depositado os calcarenitos neomorfizados da Fácies Can.

Os grainstones oolíticos da Fácies Caoo, constituem um corpo arenoso, desenvolvido em ambiente marinho de águas rasas e agitadas, e corresponderiam ao corpo principal nos ciclos Oolite Grainstone

A ocorrência de delgadas intercalações lamosas associadas ao fato de os grainstones ooliticos passarem a packstones parcialmente ooliticos indicam perda de energia no ambiente (Fácies $\mathrm{CaCl}$ ) e gradação para uma laguna de plataforma, devido à barreira formada pelo corpo oolítico.

O calcirrudito, com granodecrescência ascendente, marcas onduladas e laminação ondulada a plano-paralela no topo, representa um depósito de tempestade em águas rasas, e serviu de substrato para o desenvolvimento dos biohermas estromatoliticos. Os estromatólitos que se estabeleceram sobre o calcirrudito não apresentam intercalaçōes de lama carbonática, o que indica que o ambiente ainda apresentava certa agitação. 
A distribuição e dimensōes dos biohermas estromatolíticos da Fácies CE, ilustram de modo exemplar a mudança de ambiente, de águas agitadas de plataforma externa, para águas calmas de laguna de plataforma. Os biohermas basais săo maiores e apresentam morfologias predominantemente pseudocolunares, com alguns elementos colunares esparsos; não apresentam lama, mas sim de grãos e possuiam relevo, o que indica condições de águas claras e agitadas. Após o corpo oolítico, em direção à linha de costa, com a perda gradual de energia, começam a ocorrer intercalações lamosas; os estromatólitos passam a ser predominantemente estratiformes, de laminações planas e relevo dado pela superficie do bioherma, o que indica ambiente desfavorável ao seu desenvolvimento, devido ao aporte de material fino. Quando começam a predominar os sedimentos finos de planície de maré restrita, os estromatólitos desaparecem.

Em uma planície de maré restrita, foram depositados os calcilutitos laminados (Fácies CII) e parte dos calcissiltitos laminados (Fácies CsI); em ambiente de intermaré, talvez atingindo intermaré alta, foram depositadas as margas e os calcissiltitos laminados com intercalações de calcilutito argiloso, que para o topo apresentam gretas de contração.

Aportes periódicos de grãos, por tempestades ou marés muito fortes, geraram os delgados niveis de calcarenitos, inclusive o calcarenito oolítico.

Como semeihanças entre as fácies de planicie de maré restrita e os ciclos do tipo lime mud-sabka, tem-se o fato de que as fácies CII,CsI e MRG são predominantemente compostas por sedimento micrítico, de cor escura, com delgadas intercalaçōes peloidais, e de para o topo apresentarem sedimentos finamente laminados de planície de maré com cristais esparsos de evaporitos, o que indica condiçöes de evaporação, com concentração de sais. Também como ocorre em ciclos lime mud-sabkha, os sedimentos de ambiente restrito não apresentam evidências de erosão ou exposição subaérea prolongada, apenas leitos gretados e apresentam contato superior com leitos marinhofranco, na base do intervalo subseqüente, o que se observa no caso (Fácies Cait do Intervalo 4).

\section{4 - INTERVALO 4}

Os carbonatos que constituem o Intervalo 4 apresentam características que permitem considera-los como tendo sido depositados em uma plataforma carbonática progradante, ampla e rasa, possivelmente do tipo rimmed shelf (Figura 14).

Apresenta grandes semelhanças com o intervalo anterior e também constitui um ciclo regressivo do tipo Oolite Grainstone (Wilson 1975), caracterizado pela presença de 


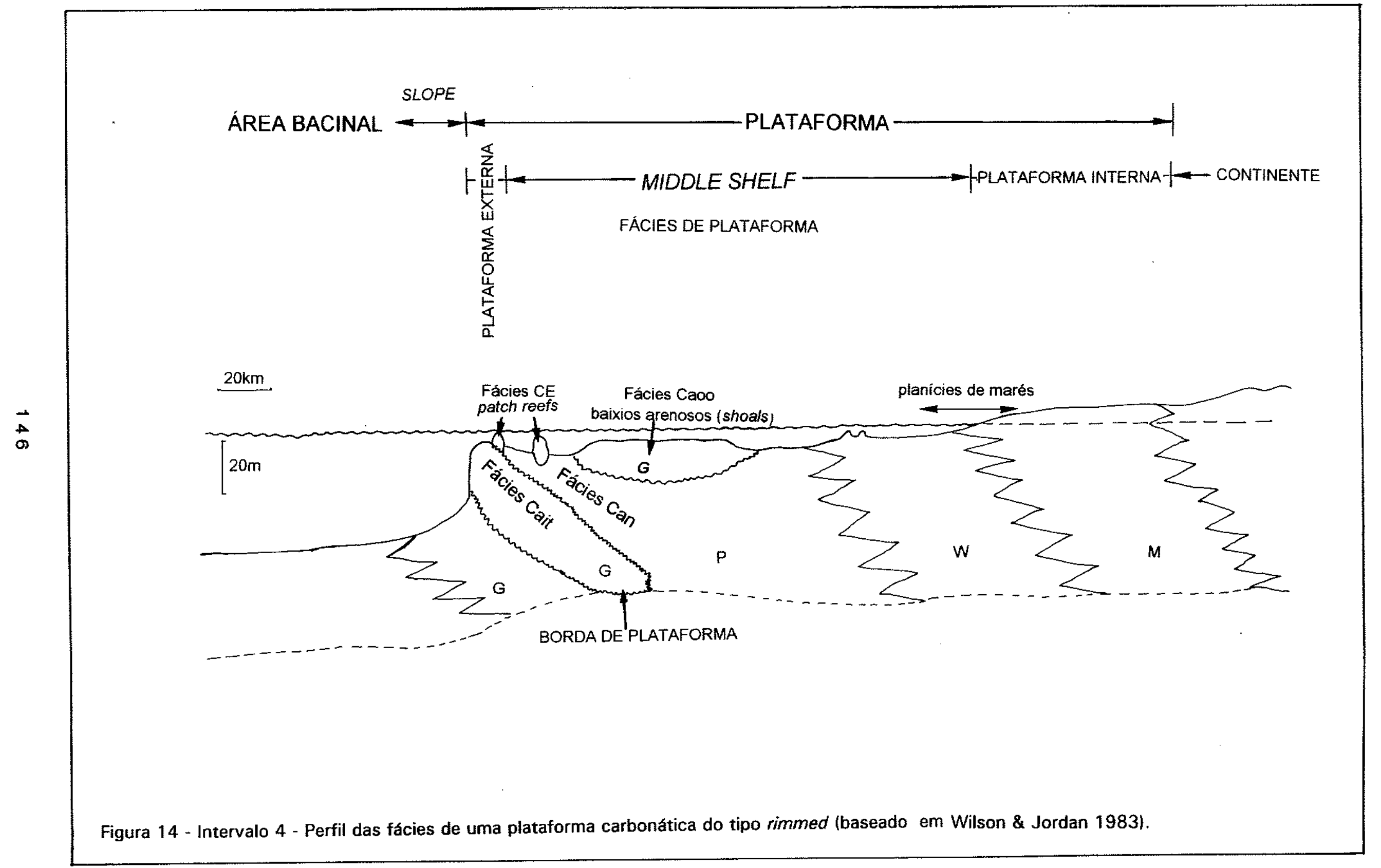


espesso pacote de calcarenito oolítico. Esse tipo de ciclo tende a se multiplicar em áreas tectonicamente estáveis, o que ocorre na área. A presença de camadas fraturadas, com ondulaçōes amplas e variaçōes bruscas de mergulho representa um evento tectônico pós deposicional, e afeta os carbonatos apenas localmente.

Neste intervalo foram identificados os seguintes conjuntos faciológicos: Conjunto de Fácies G4, composto pelas fácies Cait e CE, de plataforma externa; as Fácies Can e Caoo, compõe o Conjunto de Fácies H4, depositado em middle shelf

No Conjunto Faciológico G4, o grainstone intraclástico (Fácies Cait), representaria a fase de inundação extensiva da plataforma, tendo sido depositado em ambiente situado abaixo do nivel de ação de ondas normais.

O desenvolvimento de biohermas estromatolíticos sobre sedimentos arenosos ou talvez hardgrounds, sugere águas não muito agitadas e/ou baixa taxa de sedimentação, pois a fixação e desenvolvimento dos estromatólitos não seria possivel se o substrato tivesse alta mobilidade. Os biohermas estromatoliticos (Fácies CE) constituiam barreiras recifais semelhantes a patch reefs e desenvolveram-se próximo à borda da plataforma carbonática, em inframaré. Como não se observa lama carbonática nas laminações estromatolíticas e existe material arenoso entra as colunas, o ambiente deveria apresentar águas algo agitadas

O Conjunto de Fácies H4, composto pelas fácies Can e Caoo, foi depositado em ambiente de middle shelf.

A Fácies Can representaria ambiente situado possivelmente abaixo do nivel de ação de ondas normais, o que teria permitido a deposição de calcilutitos.

O pacote de calcarenito oolítico (Fácies Caoo), representa um importante corpo arenoso (shoal), desenvolvido em águas rasas e agitadas, com oólitos bem formados e com envelopes concêntricos bem desenvolvidos. São característicos de ciclos Oolite Grainstone e possivelmente isolaram uma laguna de plataforma, não restrita, como se observa pela presença de agregados do tipo grapestones em calcarenito oolítico, no topo da fácies.

0 Intervalo 4, embora extremamente semelhante ao intervalo precedente, representa uma transgressão que instalou um regime de águas mais profundas que no Intervalo 3, pois apresenta biohermas estromatolíticos possantes, maiores que os encontrados no intervalo anterior, bem como um corpo arenoso, oolítico, é muito mais espesso. 


\section{5 - DISCUSSÃO DOS MODELOS DE PLATAFORMA ADOTADOS}

O modelo de evolução da plataforma carbonática adotado para as rochas do Grupo Bambuí na região de Arcos, foi o de uma rampa carbonática, que evoluiu para plataforma do tipo rimmed shelf. Segundo Read (1982) esses tipos de plataforma carbonática são característicos de margens continentais passivas (extensionais) e podem ser definidos pela geometria de seus componentes e perfil de transição da plataforma para a área bacinal.

O Intervalo 1 foi considerado como tendo se desenvolvido em uma plataforma carbonática em rampa, talvez do tipo distally steepened. Rampas, segundo Read (op. cit.), apresentam mergulho muito baixo, menos de $1^{0}$ por quilometro, apresentam fácies de águas agitadas próximo à linha de costa que passam, sem variação expressiva de mergulho, para fácies de águas profundas, de baixa energia. Assim, observa-se que depósitos cíclicos, perilitorâneos, lagunares ou de planicies de maré, gradam a complexos de baixios arenosos (shoals) de alta energia, eventualmente com desenvolvimento de ilhas-barreiras em rampa interna, e passam para carbonatos argilosos, depositados em ambientes distais. A variação de fácies descrita para uma plataforma carbonática do tipo rampa, se enquadra perfeitamente no que foi observado no intervalo basal, que pode assim ser caracterizado. Rampas podem ainda ser homoclinais, isto é, não possuem quebra de relevo ou distally steepened, que apresentam quebra de relevo em regiöes distais, situadas a muitos quilômetros da linha de costa. Em rampas homoclinais, depósitos de sedimentos por fluxos de gravidade são raros ou mesmo ausentes; em rampas do tipo distally steepened, devido à quebra de relevo, depósitos por fluxos de gravidade são abundantes, com brechas de "talude", escorregamentos e turbiditos, os quais são sempre compostos por clastos autóctones, sem contaminação por clastos de ambientes costeiros. A preferência pelo modelo de rampa com quebra de relevo em porções distais (distally steepened) é decorrente da presença, na área pesquisada, de freqüentes niveis de calcirruditos maciços, compostos por intraclastos autóctones (Fácies $\mathrm{Cr}$ ), sem evidências de fácies de águas rasas, irregularmente distribuidos em meio a calcissiltitos de ambiente distal, o que sugere tratar-se de depósitos gerados por fluxos gravitacionais, possivelmente do tipo debris flow, relacionados a eventos de tempestades, em regiōes de quebra da rampa.

O Intervalo 2 possivelmente representa ainda uma plataforma carbonática em rampa, quando ligeira subida do nivel do mar instalou um regime de águas rasas, após evento de exposição subaérea que afetou as fácies perilitorâneas do Intervalo 1. 
Os intervalo 3 e 4 foram caracterizados como plataformas carbonáticas do tipo rimmed shelf, isto é, que apresentam quebra de relevo em regiões proximais.

As principais feições de plataformas com quebra de relêvo em regiōes proximais são, segundo Read (1982): a presença, em ambiente perilitorâneo, de carbonatos gerados, no geral em planicies de marés, onde compōem pequenas sucessōes regressivas e a presença em ambiente de plataforma externa e de middle shelf, de areias oolíticas com estratificaçäo cruzadas, patch reefs, e de bancos lamosos relacionados a lagunas de plataforma. A presença nos intervalos 3 e 4 das características clássicas de plataformas do tipo rimmed shelf, permite considerá-los como tendo se desenvolvido em plataformas desse tipo. $O$ fato de apresentarem características de ciclos Oolite Grainstone e Lime mudsabkha, como descrito nos itens 7.3 e 7.4, também reforçam essa assertiva,

A evolução de uma plataforma carbonática no geral também é compativel com o que se observa na área; rampas no geral são precursoras de rimmed shelves, pois se desenvolvem inicialmente em uma superficie de baixa declividade, onde a grande produção de carbonato na área de alta energia cria um contraste com a regiảo distal, onde a produção de carbonato é muito mais baixa, o que gera um primeiro desnivel, uma quebra na rampa, que pode evoluir então para uma plataforma rimmed.

Grotzinger (1989) considera que as plataformas carbonáticas proterozóicas, por se desenvolverem em ambientes cratônicos estáveis e amplos, estiveram sujeitas ao mesmo tipo de controle tectônico que regulou a periodicidade e crescimento das plataformas fanerozóicas. 


\section{8 - CONCLUSŐES FINAIS}

1- Com base nos conjuntos faciológicos descritos e na sua sucessão vertical, concluiu-se que as rochas do Grupo Bambui na área estudada registram um grande ciclo regressivo, composto por quatro ciclos regressivos menores, denominados Intervalos, que se estabeleceram após rápidas transgressões marinhas.

2- O Intervalo 1, basal, apresenta na base condiçöes de águas profundas, de ambiente distal, mas com luminosidade suficiente para permitir a fotossíntese, e termina com uma superficie de exposição subaérea, onde se observam zonas de dissolução e talvez um nivel de calcrete laminado. Foi considerado como representando um modelo de Plataforma Carbonática do tipo unimmed sheff, composta em sua parte distal por uma rampa, talvez do tipo distally steepened, que grada através de uma barreira arenosa regressiva a ambientes perilitorâneos de diferentes niveis de energia, a depender da profundidade em que se encontravam os corpos arenosos. Onde as barreiras eram emergentes, isolaram uma laguna de circulação restrita, onde se desenvolveram estromatólitos de pequeno porte, colunares a pseudocolunares, que grada a uma planície de maré de baixa energia; onde as barreiras se situavam a maior profundidade, formaramse corpos arenosos ooidais, de ambiente de alta energia, associados a estromatólitos dômicos e colunares de grande porte, que gradam a biostromas estromatolíticos, desenvolvidos em ambiente de intermaré.

As unidades estromatoliticas que se desenvolveram em ambiente perilitorâneo estão dolomitizadas e mostram evidências de exposição subaérea, com dissolução de grãos, abertura de cavidades e formaçäo de brechas de colapso que apresentam clastos com franja isópaca de dolomita e estão cimentados por calcita espática.

3- O Intervalo 2 representa a inundação de uma ampla área afetada por processos subaéreos, e a instalação de uma plataforma carbonática progradante, de águas rasas, com planícies de maré em direção à linha de costa. Observa-se nesse intervalo, a existência de várias sucessōes regressivas menores, indicativas de oscilaçöes do nível do mar e características de planícies de marés.

Em um regime de águas quentes, com concentração de sais, possivelmente em clima semi-árido, proliferaram estromatólitos estratiformes, com formas dômicas e colunares subordinadas e pouco desenvolvidas. Constituia um ambiente altamente propicio ao desenvolvimento de vida, pois é basicamente estromatolítico, e não apresenta aportes 
importantes de material externo, uma vez que o principal material granular é constituído por microfitólitos, que possuem uma participação orgânica importante na sua formação.

4- O Intervalo 3 inicia-se com uma transgressão marinha que instalou um regime de águas mais profundas, em uma plataforma carbonática possivelmente do tipo rimmed shelf. Biohermas estromatolíticos desenvolveram-se próximo à borda da plataforma, e atrás de barras arenosas oolíticas, em ambiente lagunar. Gradativamente 0 ambiente se torna cada vez mais restrito, passando a uma planície de maré lamosa, de baixa energia. As intercalaçōes arenosas que ocorrem nos sedimentos de planície de maré constituem depósitos proximais de tempestades; os calcilutitos de topo, com intercalaçōes de material argiloso de cor creme atestam contaminaçäo por terrigenos, em ambiente sujeito a ressecações, com gretas de contração.

As fácies basais do Intervalo 3 constituem um ciclo regressivo do tipo Oolite Grainstone (Wilson 1976), que gradam, em direçäo à linha de costa, a ambientes restritos que guardam semelhanças com ciclos do tipo Lime Mud-Sabkha.

5- O Intervalo 4 também constitui um ciclo Oolite Grainstone, extremamente semelhante ao Intervalo 3. Representa uma transgressão com águas mais profundas que o ciclo anterior, como se observa pelas dimensões dos biohermas estromatolíticos que são muito maiores que as do Intervalo 3, bem como a espessura do corpo oolítico é significativamente maior. Segundo Wilson (1976), esses ciclos são característicos de plataformas cratônicas rasas e amplas e tendem a se repetir em áreas tectonicamente estáveis, compondo uma seqüência estratigráfica maior, de caráter regressivo, o que se confirma na área pesquisada para os intervalos 3 e 4.

6- A evoluçăo da plataforma carbonática observada na regiäo de Arcos, considerada como constituindo uma rampa no Intervalo 1 e plataformas do tipo rimmed shelf nos intervalos 3 e 4, é bastante comum em rochas carbonáticas proterozóicas. Como ocorre em plataformas carbonáticas fanerozóicas, rampas proterozóicas são importantes precursoras no desenvolvimento de plataformas do tipo rimmed shelf, e apresentam zoneamento bem definido de fácies, que gradam de rampa externa a fácies de rampa interna, atingindo depósitos de intermarés, o que é facilmente identificável no Intervalo 1. Rimmed she/ves proterozóicas apresentam desenvolvimento de recifes estromatolíticos que formam uma barreira linear na borda da plataforma e podem apresentar barreiras oolíticas, que eventuaimente levam ao desenvolvimento de uma laguna restrita de 
plataforma; essas características são observadas nos intervalos 3 e 4, o que confirma a interpretação adotada.

7- Quanto ao aspecto climático, todo o megacicio desenvolveu-se em ambiente quente e possivelmente semi-árido como atesta a presença de cristais de evaporitos encontrados em todos os intervalos.

8- As feições diagenéticas mais importantes observadas nos carbonatos da região de Arcos foram: compactação, cimentação, substituição - dolomitização e neomorfismo. A compactaçäo, especialmente a compactação química, afeta especialmente os carbonatos basais, mais lamosos, que ocorrem no Intervalo 1; observa-se estilólitos, dissolution seams e no calcário microbiano críptico, bandeamento diagenético, não deposicional.

Cimentação precoce, sinsedimentar, com desenvolvimento de franja isópaca, é observada praticamente em todos os corpos arenosos, e em todos os intervalos; calcita espática ocorre ainda compondo mosaico, também em cavidades.

A dolomitização pode ser de dois tipos. 1- Precoce, sinsedimentar, com cristais de dolomita finamente a criptocristalina compondo um mosaico xenotópico, e preserva a textura original do carbonato; está relacionada à concentração de sais em águas rasas e poderia ser considerada uma dolomitizaçäo do tipo evaporativo. 2- Tardia, com cristais de dolomita de cristalinidade média a grossa, que oblitera a textura deposicional dos carbonatos. Eventualmente preserva a forma, mas não a estrutura dos aloquímicos e está representada na área pelo nivel regional de dolomito calcítico. Esse tipo de dolomitização pós litificação da rocha, permite a formaçäo de niveis regionais de dolomitos estratiformes, está relacionada à flutuação da interfácies existente entre águas doce e salgada e poderia caracterizar dolomitização por processo do tipo Dorag ou Mixed Water. No caso, a flutuação da cunha de água doce-salgada, estaria relacionada à transgressão que permitiu a instalação do Intervalo 2, após evento de exposição subaérea.

Processos neomórficos afetam a quase totalidade dos carbonatos estudados e freqüentemente destroem ou mascaram caracteristicas primárias das rochas.

9- A idade do Grupo Bambui ainda é discutivel, os dados são preliminares, mas continua sendo objeto de discussöes e controvérsias, sem que tenha até o momento, resultados conclusivos a respeito. Seguramente sua deposição deu-se no Proterozóico, podendo talvez ter atingido o limite Precambriano/Cambriano. De modo geral, os dados disponíveis sugerem $680 \mathrm{Ma}$ como a idade mínima para a deposição do grupo. 
Considerações sobre a idade do grupo com base em estromatólitos, Gymnosolenidae, que ocorrem fora da área estudada, pois näo se encontrou formas estromatolítica com valor bioestratigráfico, coloca-o no Rifeano Superior (Marchese 1974). Microfósseis plantônicos, Acritarchae, identificados por análise palinológica - gêneros Kildinosphaera, Trachysphaeridium, Stictosphaeridium e Protosphaeridium, apresentam ampla distribuição geográfica, pequena ocorrência estratigráfica no Proterozóico Superior e sugerem idade Rifeano Superior/Vendiano (Cruz \& Lopes 1992). Uma forma com ornamentos encontrada em calcissiltitos (Fácies Cs) e que näo foi identificada taxonomicamente, é de ocorrência mais comum no Cambriano, e poderia sugerir para o grupo uma idade mais próxima do limite Precambriano-Cambriano; a presença de formas que lembram vagamente Renalcis poderia corroborar uma idade mais próxima ao Cambriano, pois são características desse período, mas a identificação não é segura.

Dados obtidos por Babinsky (1993) indicam, embora também de modo não conclusivo, uma idade isocrônica $\mathrm{Pb} / \mathrm{Pb}$ de $686 \pm 69 \mathrm{Ma}$, considerada uma idade mínima de deposição para a Formaçäo Sete Lagoas, o que situaria o Grupo Bambuí no mínimo no Rifeano Superior e corroboraria os dados de Bonhomme (1967) e parcialmente os de Kawashita et al. (1987). Babinsky (op. cit.) obteve também idade isocrônica $\mathrm{Pb} / \mathrm{Pb}$ da ordem de 520 Ma em carbonatos da Formação Sete Lagoas a qual corresponderia a uma época de homogeneização isotópica, provavelmente relacionada aos estágios finais do Ciclo Brasiliano.

10- O espesso pacote de rochas carbonáticas que representam depósitos de tempestades, ocorre apenas no Intervalo 1 e poderia eventualmente ser utilizado como guia estratigráfico regional, o que possibilitaria correlacionar unidades sem continuidade física. As fácies de topo do Intervalo 1, onde se observa feições marcantes de dissolução, com brechas de colapso, abertura de cavidades e outras feições indicativas de exposição subaérea também pode servir como guia estratigráfico regional, em associação com o nivel de dolomito calcítico, desde que se leve em conta que essa superficie só poderá ser reconhecida em ambientes proximais, de águas rasas, não devendo ser encontrada como tal em ambientes mais distais.

11- Quanto à inserção da área pesquisada na estratigrafia formal do Grupo Bambuí, existem vários aspectos a serem discutidos e o resultado não é conclusivo. Em primeiro lugar, o Grupo Bambuí ocorre em vasta área, é pouco conhecido, apresenta variações regionais importantes e não se tem estudos sobre a evolução da sedimentação na Bacia 
do São Francisco. À excessão das intercalações pelíticas, representadas pelas formações Serra de Santa Helena e Serra da Saudade, não existem niveis definidos que possam ser utilizados como guias para correlação estratigráfica intrabacinal; mas essas intercalaçōes não estão presentes em toda a bacia e a definição das formações é bastante vaga. As seçōes-tipo descritas no trabalho de Costa \& Branco (1961) e tradicionalmente aceitas (Dardenne 1978) situam-se distantes da área estudada e não apresentam as mesmas características em toda a bacia.

Mas, mesmo com as limitações discutidas, pode-se aventar algumas hipóteses, para situar a área pesquisada na estratigrafia adotada para o Grupo Bambui. Se, por exemplo, considerarmos como obrigatória a presença de um pacote pelítico (Formaçăo Serra de Santa Helena), acima da unidade carbonática basal (Formação Sete Lagoas), os carbonatos da região de Arcos pertenceriam exclusivamente à Formação Sete Lagoas, pois năo se observa intercalação de sedimentos detríticos, não carbonáticos, em toda a área. Mas pela descrição da Formação Sete Lagoas (Costa \& Branco op. cit. e Dardenne op. cit.), apenas os intervalos 1 e 2 estariam bem caracterizados, e dificilmente os intervalos 3 e 4 poderiam ser incluídos, por serem predominantemente oolíticos, embora não se possa esquecer que diferentes fácies podem ocorrer em um mesmo horizonte, assim como fácies distintas ocorrem em diferentes horizontes.

Se por outro lado, considerarmos que o que caracteriza a Formação Lagoa do Jacaré, sobreposta à Formação Santa Helena, é a presença de calcários oolíticos, pouco representados, teoricamente, na Formação Sete Lagoas, então os intervalos 3 e 4 poderiam representar essa formação, embora os calcários encontrados na área pesquisada não sejam pretos, nem fétidos. Nesse último caso, os Intervalos 1 e 2 representariam a Formação Sete Lagoas, e nảo teria havido a deposição da Formação Santa Helena.

Em realidade, para que se possa ter uma definição estratigráfica da Bacia do São Francisco, é preciso antes trabalhar a bacia como um todo, inclusive com definição de horizontes estratigráficos regionais, o que permitiria efetuar correlações interbacinais, e possibilitaria a compreensão da evolução da bacia. A partir dai seria possivel inserir as diferentes unidades na estratigrafia formal adotada. 


\section{9 - REFERÊNCIAS BIBLIOGRÁFICAS}

ADAMS, A. E.; MACKENZIE, W. S.; GUILFORD, C. (1984) Atlas of sedimentary rocks under the microscope. 2. ed. Harlow, Longman. 104p.

AIGNER, T. (1982 ) Calcareous Tempestites: storm-dominated stratification in Upper Muschelkalk limestones (Middle Trias, SW Germany). In: EINSELE, G. R.; SEILACHER, A. (eds.) Cyclic and Event Stratification. Berlin, Springer. p.108-198.

AIGNER, T. (1985) Storm deposicional systems: dynamic stratigraphy in modern and ancient shallow-marine sequences. In: FRIEDMAN, G.M., NEUGEBAUER, H.J.; SEILACHER, A. (eds.) Berlin, Springer. 174p. (Lecture notes in Earth Sciences)

AITKEN, J. D. (1967) Classification and environmental significance of cryptalgal limestones and dolomites, with illustrations from the Cambrian and Ordovician of southwestern Alberta. Journal of Sedimentary Petrology, v. 37, n.4, p. 1163-1187.

AISSAOUI, D. M. (1990) Botryoidal aragonite and its diagenesis. In: TUCKER, M. E.; BATHURST, R. G. C. (eds.) Carbonate Diagenesis. Oxford, Blackwell. p. 135-151.

ALKMIN, F. F.; CHEMALE JR. F.; BACELLAR, L. A. P.; OLIVEIRA, J. R. P.; MAGALHÄES, P. M. (1989) Arcabouço estrutural da porçäo sul da bacia do São Francisco. In: SIMPÓSIO DE GEOLOGIA NÚCLEO DE MINAS GERAIS, 5., SIMPÓSIO DE GEOLOGIA NÚCLEO BRASÍLIA,1., Belo Horizonte,1989. Anais. Belo Horizonte, SBG - Núcleo de Minas Gerais. p. 289-293 (Boletim n. 10).

ALLEN, J. R. L. (1984) Sedimentary structures - their character and physical basis. 2. ed. Amsterdam, Elsevier, 663 p. (Developments in Sedimentology, 30).

ALMEIDA, F. F. M. de (1967) Origem e evoluçäo da plataforma brasileira. Boletim da Divisão de Geologia e Mineralogia. DNPM, n. 241, p.1-36.

ALMEIDA, F. F. M. de (1977) O Craton do São Francisco. Revista Brasileira de Geociências, v. 7, n. 4, p. 349-364. 
ALMEIDA, F. F. M. de; HASUY, Y.; BRITO NEVES, B.B. (1976) The Upper Precambrian of South America. Boletim do Instituto de Geociências, 7, p. 45-80.

AMARAL, G.; KAMASHITA, K. (1967) Determinação da idade do Grupo Bambui pelo método Rb-Sr. In: CONGRESSO BRASILEIRO DE GEOLOGIA, 21., 1967. Curitiba. Anais. Curitiba, SBG. p. 214-217.

AWRAMICK, S. M.; MARGULIS, L. (1974) Definition of stromatolites. Stromatolite Newsletter, n.2, p.5. Inédito.

BABINSKY, M. (1993) Idades isocrônicas $\mathrm{Pb} / \mathrm{Pb}$ e geoquimica isotópica de $\mathrm{Pb}$ das rochas carbonáticas do Grupo Bambui, na porção sul da Bacia do São Francisco. São Paulo, 133p. (tese de Doutorado-Instituto de Pesquisas Energéticas e Nucleares/ USP).

BAPTISTA, M.B., BRAUN, O.P.G., CAMPOS, D. de A. (1984) Léxico Estratigráfico do Brasil. Companhia de Pesquisa de Recursos Minerais. Convênio DNPMCPRM. Rio de Janeiro. 560p.

BARBOSA, O. (1955) Noticiário da Sociedade Brasileira de Geologia, São Paulo. In: CONGRESSO BRASILEIRO DE GEOLOGIA, 9., 1955, Araxá. Guia das Excursōes. Araxá, SBG. n.3, p. 3-5.

BARBOSA, O. (1965) Série Bambuí. Simpósio das Formações Eo-Paleozóicas do Brasil. In: CONGRESSO BRASILEIRO DE GEOLOGIA, 19., 1965. Publicação Avulsa. Rio de Janeiro, SBG.15p.

BARBOSA, O.; BRAUN, O. G.; DYER, R. C.; CUNHA, C. A. R. (1970) Geologia do Triângulo Mineiro. Boletim da Divisão de Fomento da Produção Mineral, DNPM, n.136, $140 p$.

BATHURST, R. G. C. (1975) Carbonate sediments and their diagenesis. 2. ed. Amsterdam, Elsevier. 658p. (Developments in Sedimentology, 12). 
BATHURST, R. G. C. (1980) Stromatactis - Origin related to submarine-cemented crusts in Paleozoic mud mounds. Geology, v. 8, p. 131-134.

BATHURST, R. G. C. (1987) Diagenetically enhanced bedding in argillaceous platforms limestones: stratified cementation and selective compactation. Sedimentology, v. 34, p. 749-779.

BERTRAND-SARFATI, J. (1972) Stromatolites columnaires du Precambrien Superieur, Sahara nord-occidental. Inventaire, morphologie et microestructure des laminations, correlations stratigraphiques. Centre de Récherches sur les zones arides. Série Géologie, n.14, p. 1-245.

BERTRAND-SARFATI, J.; MOUSSINE-POUCHKINE, A. (1983) Platform to basin facies evolution: the carbonates of Late Proterozoic (Vendian) Gourma (West Africa). Journal of Sedimentary Petrology. v. 53, n. 1, p. 275-293.

BONHOMME, M. G. (1976) Mineralogie des fractions fines et datations rubidium-strontium dans le Groupe Bambui, Minas Gerais, Brésil. Revista Brasileira de Geociências, São Paulo. v.6, n.4, p. 211-222.

BRASIL - Departamento Nacional da Produção Mineral. (1982) Projeto RADAMBRASIL, Foiha SD.23, Brasilia. Levantamento de Recursos Naturais. Rio de Janeiro. v. 29, p. 1660.

BRAUN, O. P. G. (1968) Contribuição à estratigrafia do Grupo Bambuí. In: CONGRESSO BRASILEIRO DE GEOLOGIA, 22., 1968. Belo Horizonte. Anais. Belo Horizonte, SBG. p. 155-166.

BRITO NEVES, B. B.; KAWASHITA, K.; DELHAL, J. (1979 ) A evolução geocronológica da corditheira do Espinhaço: dados novos e integração. Revista Brasileira de Geociências, v. 9, n. 1, p. 71-85.

BURNE, R. V.; MOORE, L. S. (1987) Microbialites: organossedimentary deposits of benthic microbial communities. Palaios, v. 2, p.241-254. 
CHOQUETTE, P. W.; PRAY, L. C. (1970) Geologic nomenclature and classification of porosity in sedimentary carbonates. Bulletin of American Association of Petroleum Geologists, v. 54, n. 2, p. 207-250.

CLOUD, P. E.; DARDENNE, M. A. (1973) Proterozoic age of Bambui Group in Brazil. Bulletin of the Geological Society of America, v. 84, n. 5, p. 1673-1676.

CONIGLIO, M.; DIX, G.R. (1992) Carbonate slopes. In: WALKER, R.G.; JAMES, N.P. (eds.) Facies Models - Response to Sea Level Change. St. John's, Geological Association of Canada. p.349-374.

CORDANI, U. G. (1973) A Geologia do Pré-Cambriano do nordeste da Bahia-oeste de Sergipe. In: CONGRESSO BRASILEIRO DE GEOLOGIA, 27., 1973. Aracaju. Anais. Aracaju, SBG. v. 2, p. 151-158.

COSTA, M. T.; BRANCO, J. J. R. (1961) Introdução. In: BRANCO, J.J.R. Ed. Roteiro para a excursão Belo Horizonte-Brasília. In: CONGRESSO BRASILEIRO DE GEOLOGIA, 14., 1961. Belo Horizonte. Instituto de Pesquisas Radioativas da Universidade Federal de Minas Gerais. n. 15, p. 1-119.

COSTA, L. A. M. da; ANGEIRAS, A. G.; VALENÇA, J. G.; STEVENAZZI, V. (1970) Novos conceitos sobre o Grupo Bambui e sua divisão em tectonogrupos. Boletim de Geologia do Instituto de Geociências, n. 5, p. 3-34.

COUTO, J. G. P.; BEZ, L. (1981) A Glaciaçäo Jequitaí. Um guia estratigráfico para o Precambriano superior no Brasil. Revista Brasileira de Geociências, São Paulo, v.11, n. 1, p. 17-21.

COUTO, J. G. P.; CORDANI, U. G.; KAWASHITA, K; IYER, S. S.; MORAES, N. M. P. (1981) Consideraçōes sobre a idade do Grupo Bambui, com base em análises isotópicas de Sr e Pb. Revista Brasileira de Geociências, v. 5, p. 5-16. 
DARDENNE, M. A. (1978) Sintese sobre a estratigrafia do Grupo Bambuí no Brasil central. In: CONGRESSO BRASILEIRO DE GEOLOGIA, 30., 1978. Recife. Anais. Recife, SBG. v. 2, p. 597-610.

DARDENNE, M. A; WALDE, D. H. G. (1979) A estratigrafia dos Grupos Bambui e Macaúbas no Brasil central. In: SIMPÓSIO DE GEOLOGIA DE MINAS GERAIS, 1., 1979. Belo Horizonte. Anais. Belo Horizonte, SBG. p. 43-45.

DELLA FAVERA, J. C. (1990) Tempestitos da Bacia do Parnaiba. Porto Alegre, p. 1243. (Tese de Doutorado - Instituto de Geociências/ Universidade Federal do Rio Grande do Sul).

DERBY, O. A. (1879) Contribuição para o estudo da geologia do valle do São Francisco. Archivo do Museu Nacional, Rio de Janeiro. n. 4, p. 87-119.

DERBY, O. A. (1880) Reconhecimento geológico do valle do São Francisco. In: Brasil Comissão Hidrographica do Rio São Francisco. Relatório..., Rio de Janeiro. Anexo 1, p. 1-24.

DERBY, O. A. (1880) Geology of the rio São Francisco, Brazil. American Journal of Science, v. 19, n. 11, p. 236.

DUNHAM, R. J. (1962) Classification of carbonate rocks according to depositional texture. Memoir AAPG, n.1, p.108 -121.

EINSELE, G. (1991) Submarine mass deposits and turbidites. In: EINSELE, G.; RICKEN, W.; SEILACHER, A. (eds.) Cycles and Events in Stratigraphy. Berlin, Springer. p.313-339.

EINSELE, G.; SEILACHER, A (1982) Paleogeographic significance of tempestites and periodites. In: EINSELE, G.; SEILACHER, A. (eds.) Cyclic and Event Stratification. Berlin, Springer. p. 531-536. 
EMBRY, A. F.; KLOVAN, J. E. (1971) Late Devonian reef tracts on northeastern Banks Islands, Northwest Territories. Canadian Petrology and Geology Bulletin, v.19,p.730-781.

ENOS, P.; MOORE, C. H. (1983) Fore-reef slope. In: SCHOLLE, P. A.; BEBOUT, D. G.; MOORE, C. H. (eds.) Carbonate Depositional Environments. Memoir AAPG, n. 33, p. 507-538.

FAIRCHILD, I. J.; HERRINGTON, P. (1989) A Tempestite - Stromatolite - Evaporite Association (Late Vendian, east Greenland); a shoreface lagoon model. Precambrian Research, v. 43, p. 101-127.

FOLK, R. L. (1959) Pratical petrographic classification of limestones. Bulletin of American Association of Petroleum Geologists, v. 43, n. 1, p. 1-38.

FOLK, R. L. (1962) Spectral subdivision in limestone type. Memoir AAPG, n.1, p. 62-84.

FOLK, R. L. (1965) Some aspects of recristallization in ancient limestones. In: PRAY, L.C., MURRAY, R.C. (eds.) Dolomitization and Limestone Diagenesis, a Symposium. Tulsa,SEPM. p.14-48 (Society of Economic Paleontologists and Mineralogists. Special Publication, 13).

FOLK, R. L. (1980) Petrology of Sedimentary rocks. 2. ed. Austin, Hemphill's. 170 p.

FREIBERG, B. von (1932) Resultados das pesquisas geológicas em Minas Gerais Brasil. Tradução. In: CONGRESSO BRASILEIRO DE GEOLOGIA 19., 1965. Rio de Janeiro. Simpósio das Formaçōes Eo-Paleozóicas do Brasil. SBG. 222 p.

GEBELEIN, C.D. (1974) Biologic control of stromatolite microstructure: implications for Precambrian time stratigraphy. American Journal of Science, v. 274, p. 575-598.

GREY, C.; AWRAMICK, S. M.; BERTRAND-SARFATI, J.; HOFMANN, H. J.; PRATT,B. R.; WALTER, M. R.; SHIXING, Z. (1992) Handbook for the study of stromatolites and related structures. 4th draft. Inédito. 
GROTZINGER, J. P. (1986) Cyclicity and paleoenvironmental dynamics, Rocknest platform, northwest Canadá. Bulletin of Geological Society of America, v. 97, n. 10, p. $1208-1231$.

GROTZINGER, J. P. (1989) Facies and evolution of the Precambrian carbonate deposicional systems: emergence of the modern platform archetype. In CREVELLO, P. D.; WLSON, J. L.; SARG, J. F.; READ, J. F.; (eds.) Controls on Carbonate Platform and Basin Development. Tulsa, SEPM. p.79-106. (Society of Economic Paleontologists and Mineralogists. Special Publication, 44).

HALLEY, R.B. (1976) Textural variations within Great Salt Lake algal mounds In: WALTER, M.R. (ed.) Stromatolites. Amsterdam, Elsevier. p. 435-446. (Developments in Sedimentology, 20).

HARRIS, P. M.; KENDAL, C. G. St. C.; LERCHE, I. (1985) Carbonate cementation: a brief review. In: SCHNEIDERMANN, N. R.; HARRIS, P. M. (eds.) Carbonate Cements: based on a symposium sponsored by the Society of Economic Paleontologists and Mineralogists. Tulsa, SEPM. p. 79-95. (Society of Economic Paleontologists and Mineralogists. Special Publication, 36).

HOFFMAN, P. (1976) Stromatolite morphogenesis in Shark Bay, western Australia. In: WALTER, M.R. (ed.) Stromatolites. Amsterdam, Elsevier. p. 262-271. (Developments in Sedimentology, 20).

HOFMANN, H. J. (1969) Attributes of stromatolites. Paper 69-39. Ottawa, Geological Survey of Canada. p. 1-58.

IRWN, M. L. (1965) General theory of epeiric clear water sedimentation. Bulletin of American Association of Petroleum Geologists, v. 49, n. 4, p. 445-459.

JAMES, N. P.; BOURQUE, P. A. (1992) Reefs and Mounds. In: WALKER, R.G.; JAMES, N.P. (eds.) Facies Models - Response to Sea Level Change. St. John's, Geological Association of Canada. p. 323-348. 
JAMES, N. P.; KENDALL, A. C. (1992) Introduction to carbonate and evaporite facies models. In: WALKER, R. G.; JAMES, N. P. (eds.) Facies Models - Response to Sea Level Change. St. John's, Geological Association of Canada. p.265-276.

JONES, B.; DESROCHERS, A. (1992) Shallow Platforms Carbonate. In: WALKER, R. G.; JAMES, N. P. (eds.) Facies Models - Response to Sea Level Change. St. John's, Geological Association of Canada. p. 277-302.

KARFUNKEL, J.; HOPPE, A. (1988) Late Proterozoic glatiation in central - eastern Brazil: synthesis and model. Palaeogeography, Palaeoclimatology, Palaeoecology, v.65, n. 1/2, p. 1-21.

KAWASHITA, K.; MIZUZAKI, A. M. P.; KIANG,C.H. (1987) Razöes ${ }^{87} \mathrm{Sr} /{ }^{80} \mathrm{Sr}$ em sedimentos carbonárticos do Grupo Bambui (MG): In: CONGRESSO BRASILEIRO DE GEOQUIMICA, 1., Porto Alegre, 1987. Anais. Porto Alegre, Sociedade Brasileira de Geoquímica. v. 1, p. 133-137.

KIANG, C. H.; MIRANDA, F. P.; MAGALHÄES, L.; ALKMIN, F. F. (1988) Consideraçōes sobre a evolução tectônica da Bacia do São Francisco. In: CONGRESSO BRASILEIRO DE GEOLOGIA, 35., 1988. Belém. Anais. Belém, SBG. v.5, p. 20762090.

KREIZA, R. D.; BAMBACH, R. K. (1982) The role of storm process in generating shell beds in paleozoic shelf environments. In: EiINSELE, G.; SEILACHER, A. (eds.) Cyclic and Event Stratification. Berlin, Springer. p. 200 -207.

LOGAN, B. W.; REZACK, R.; GINSBURG, R. N. (1964) Classification and environmental significance of algal stromatolites. Journal of Geology, v.72, p. 68-83.

McCROSSAN, R. G. (1958) Sedimentary "boudinage" structures in the Upper Devonian Ireton Formation of Alberta. Journal of Sedimentary Petrology, v. 28, n. 3, p. 316-320. 
MADALOSSO, A; VERONESE, V. F. (1978) Considerações sobre a estratigrafia das rochas carbonatadas do Grupo Bambuí na região de Arcos, Pains e Lagoa da Prata (MG). In: CONGRESSO BRASILEIRO DE GEOLOGIA, 30., 1978. Recife. Anais. Recife, SBG. v. 2, p. 635-648.

MAGALHÃES, L. (1988) Análise estrutural qualitativa nos sedimentos do Grupo Bambuí, região sudeste da Bacia do São Francisco (Faixa Sete Lagoas - Serra do Cipó). Ouro Preto, p. 1-109. (Tese de Mestrado - Departamento de Geologia da Escola de Minas / Universidade Federal de Ouro Preto ).

MAGALHÃES, P. M. (1989) Análise estrutural qualitativa das rochas do Grupo Bambui na porção sudoeste da Bacia do São Francisco. Ouro Preto, p. 1-100. (Tese de Mestrado - Departamento de Geologia da Escola de Minas / Universidade Federal de Ouro Preto).

MARCHESE, H. G. (1974) Estromatolitos Gymnosolenides en el lado oriental de Minas Gerais, Brasil. Revista Brasileira de Geociências, v. 4, n.4, p. $257-271$.

MARINI, O. J.; FUCK, R. A.; DANNI, J.C. M.; DARDENNE, M. A.; LOGUÉRCIO, S. O. C.; RAMALHO, R. (1984) As faixas de dobramentos Brasilia, Uruaçu e Paraguai-Araguaia e o Maciço Mediano de Goiás. In: SCHOBBENHAUS, C.; CAMPOS, D. A.; DERZE, G. R.; ASMUS, H. E. Geologia do Brasil: texto explicativo do mapa geológico do Brasil e da área oceânica adjacente incluindo depósitos minerais. Escala 1:2.500.000. Brasília, DNPM. p.251 - 303.

MIRANDA, J. (1952) Estado de Minas Gerais. Relatório Anual do Diretor. Divisão de Geologia e Mineralogia. DNPM, 1951, p.30 - 34.

MIRANDA, J. (1953) Folha de Bambuí. Relatório Anual do Diretor. Divisão de Geologia e Mineralogia. DNPM, 1952, p.25-27.

MONTY, C. L V. (1967) Distribuition and structure of recent stromatolitic algal mats, eastern Andros Islands, Bahamas. Annales de la Société Géologique de Belgique, v. 90, n. 3, p. 1-99. 
MONTY, C. L. V. (1976) The Origin and development of cryptalgal fabrics. In: WALTER, M.R. (ed.) Stromatolites. Amsterdam, Elsevier, p. 193-249.

MONTY, C. (1981) Spongiostromate vs. Porostromate stromatolites and oncolites. In: MONTY, c. (ed.) Phanerozoic Stromatolites - Case Histories. Berlin, Springer. p. 14. (International Symposium on Fossil Algae).

OLIVEIRA, M. A. M. (1967) Contribuição à geologia da parte sul do São Francisco e áreas adjacentes. Ciência, Técnica e Petróleo, n. 3, p.71-105.

PFLUG, R.; RENGER, F. E. (1973) Estratigrafia e evolução geológica da margem SE do Craton Sanfranciscano. In: CONGRESSO BRASILEIRO DE GEOLOGIA, 27., 1973. Aracaju. Anais. Aracaju, SBG. v. 2, p. 5-19.

PLAYFORD, P. E.; COCKBAIN, A. E. (1976) Modern algal stromatolites at Hamelin Pool, a hypersaline barred basin in Shark Bay, Western Australia. In: WALTER, M.R. (ed.) Stromatolites. Amsterdam, Elsevier. p.389-412.

PRATT, B. R. (1982) Stromatolitic framework of carbonate mud-mounds. Journal of Sedimentary Petrology, v. 52, n. 4, p. 1203-1227.

PRATT, B. R. (1982a) Limestone response to stress: pressure solution and dolomitization - Discussion and examples of compaction in carbonate sediments. Journal of Sedimentary Petrology, v. 52, n. 1, p. 323-334a.

PRATT, B. R. (1984) Epiphyton and Renalcis - diagenetic microfossils from calcification of coccoid blue - green algae. Journal of Sedimentary Petrology, v. 54, n. 3, p. 948-971.

PRATT, B. R.; JAMES, N. P. (1986) The Saint George Group (Lower Ordovician) of western Newfoundland: tidal flat island model for carbonate sedimentation in shallow epeiric seas. Sedimentology, n. 33, p.313-343. 
PRATT, B. R.; JAMES, N. P.; COWAN, C. A. (1992) Peritidal Carbonates. In: WALKER, R. G.; JAMES, N. P. (eds.) Facies Models - Response to Sea Level Change. St. John's, Geological Association of Canada. p. 303-322.

RAGOT, J.P. (1976) Evolution du degré d'organisation des particules carbonées disseminées dans les roches. Bulletin du Centre de Recherches de Pau, v.10, n.1, p.221-251.

READ, J.F. (1982) Carbonate platforms of passive (extensional) continental margins: types, caracteristics and evolution. Tectonophysics, v.81, p.195-212.

RICKEN, W.; EDER, W. (1991) Diagenetic modifications of calcareous beds - an overview. In: EINSELE, G.; RICKEN, W.; SEILACHER, A. (eds.) Cycles and Events in Stratigraphy. Berlin, Springer, p. 430-449.

RIDING, R. (1991) Classification of microbial carbonates. In: RIDING, R. (ed.) Calcareous Algae and Stromatolites. Berlin, Springer. p. 21-52.

RIMANN, E. (1917) A Kimberlita no Brasil. Anais da Escola de Minas. Ouro Preto, v. 15, p. 27-32.

SCHOBBENHAUS FILHO, C.; CAMPOS,D. A.; DERZE, G. R.; ASMUS, H. E. (1984) Geologia do Brasil: texto explicativo do Mapa Geológico do Brasil e da área oceânica adjacente incluindo depósitos minerais. Escala 1:2.500.000. Brasília, DNPM. (Mapa composto por 4 partes).

SCHOLL, W. U. (1976) Sedimentologia e geoquímica do Grupo Bambuí, na parte sudeste da Bacia do São Francisco. In: CONGRESSO BRASILEIRO DE GEOLOGIA, 29., 1976. Ouro Preto. Anais. Belo Horizonte, SBG. v. 2, p. 207-231.

SCHOLLE, P. A. (1978) A Color illustrated guide to carbonate rock constituents, textures, cements and porosities. Memoir AAPG, n.27, p.1-241.

SCHOLLE, P. A.; BEBOUT, D. G.; MOORE, C. H. (eds.) (1983) Carbonate depositional environments. Memoir AAPG, n. 33, p.1-708. 
SEILACHER, A.; AIGNER,T. (1991) Storm deposition at the bed, facies and basin scale: the geologic perspective. In: EINSELE, G.; RICKEN, W.; SEILACHER, A. (eds.) Cycles and Events in Stratigraphy. Berlin, Springer. p.249-312.

SWETT, K.; KNOLL, A. H. (1985) Stromatolitic bioherms and microphytolites from Late Proterozoic Draken Conglomerate formation, Spitsbergen. Precambrian Research, v. 28, p.327-347.

TUCKER, M. E. (1982) The Field description of sedimentary rocks. Milton Keynes, Open University Press. 112p. (Geological Society of London Handbook).

TUCKER, M. E. (1990) Dolomites and dolomitization models. In: TUCKER, M.E.; WRIGHT, V.P. (eds.) Carbonate sedimentology. 1. ed. Oxford, Blackwell. p. 365-400.

TUCKER, M.E.; WRIGHT, V.P. (1990) Carbonate sedimentology. 1. ed. Oxford, Blackwell. 482 p.

WANLESS, H. R. (1979) Limestone response to stress: pressure solution and dolomitization. Journal of Sedimentary Petrology, v. 49, n. 2, p. 437-462.

WHISONANT, R.C. (1987) Paleocurrent and petrographic analysis of imbricated intraclast in shallow-marine carbonates, Upper Cambrian, southwestern Virginia. Journal of Sedimentary Petrology, v. 57, n. 6, p.983-994.

WLSON, J. L. (1975) Carbonate facies in geologic history. 7. ed. New York, Springer. 471p.

WLSON, J.L.; JORDAN, C. (1983) Middle shelf environment. In: SCHOLLE, P.A.; BEBOUT, D.G.; MOORE, C. H. (eds.) Carbonate depositional environments. Memoir AAPG, n. 33, p.298-343. 